RENATA SILVA TROVÃO

\title{
ANÁLISE AMBIENTAL DE SOLOS E ÁGUAS SUBTERRÂNEAS CONTAMINADAS COM GASOLINA: ESTUDO DE CASO NO MUNICÍPIO DE GUARULHOS - SP
}

Dissertação apresentada à Escola Politécnica da Universidade de São Paulo para obtenção do Título de Mestre em Engenharia 
RENATA SILVA TROVÃO

\section{ANÁLISE AMBIENTAL DE SOLOS E ÁGUAS SUBTERRÂNEAS \\ CONTAMINADAS COM GASOLINA: ESTUDO DE CASO NO MUNICÍPIO DE GUARULHOS - SP}

Dissertação apresentada à Escola Politécnica da Universidade de São Paulo para obtenção do Título de Mestre em Engenharia

Área de Concentração: Engenharia Mineral

Orientador: Prof. Dr.

José Renato Baptista de Lima 


\section{FICHA CATALOGRÁFICA}

Trovão, Renata Silva

Análise ambiental de solos e águas subterrâneas contaminadas com gasolina: estudo de caso no Município de Guarulhos SP I R.S. Trovão. -- São Paulo, 2006.

$157 \mathrm{p}$.

Dissertação (Mestrado) - Escola Politécnica da Universidade de São Paulo. Departamento de Engenharia de Minas e de Petróleo.

1.Reabilitação de áreas degradadas (Contaminação) Guarulhos (SP) 2.Gasolina 3.Poluição ambiental 4.Poluição da água I.Universidade de São Paulo. Escola Politécnica.

Departamento de Engenharia de Minas e de Petróleo Il.t. 
À minha Mãe Cleusa que tem sido meu maior exemplo de dedicação $\mathrm{e}$ perseverança e ao meu Pai Normando, que consegue me nortear mesmo do outro lado da vida, minha gratidão eterna. 


\section{AGRADECIMENTOS}

À Deus por guiar meus passos.

Ao Prof. Dr. José Renato Baptista de Lima por suas diretrizes seguras e incentivo constante.

À família que consegui completar durante a jornada do mestrado: minha filha Samara por sua compreensão, ajuda no paint (quando a tendinite apertou) e por ser minha grande motivação e meu marido Ruberlan por estar presente como grande companheiro me apoiando e estendendo sua mão ao menor sinal de esmorecimento, além de compartilhar seus conhecimentos de química orgânica que tanto foram úteis.

À minha grande família por entender minha ausência em momentos importantes, meus tios e primos, muito obrigada.

Meus avós grande exemplo de dignidade e integridade.

Minha irmã Flávia e meu cunhado Leonardo por perdoarem minha irritabilidade com as pessoas mais próximas e que com certeza tanto amo.

Meu irmão Rodrigo e a quase cunhada Simone pela ajuda no Corel.

À minha prima Vanessa pelos conselhos que, mesmo gestante da Gabriela, me direcionou incansavelmente, quando se tratava de paciência. Ao Dr. Danilo, meu querido primo que se dedicou aos meus interesses judiciais enquanto transcorria a dissertação. E à prima Paula pela grande ajuda poliglota.

À minha sogra Valda por sua força e determinação. Aos meus cunhados Flávio, Diogo, Diego e Alessandra pela compreensão do grande tempo ausente.

À minha irmã postiça Solange e sobrinho Renan por sua garra e coragem de começar de novo. Minha admiração e respeito ao amigo Prof. Dr. Hugo Antonio Vilca Meléndez, por acreditar no meu potencial e me ensinar o "caminho das pedras".

Aos demais professores do curso de Química da Universidade Guarulhos que fizeram brotar minha paixão pelo assunto.

À Cetesb, principalmente ao Comitê de Capacitação, que permitiu minha liberação para que este estudo fosse possível.

Ao Dr. Nelson Vasconcelos, o primeiro a defender minha causa junto à Cetesb.

Ao corpo técnico e administrativo da Cetesb - Agência Ambiental de Guarulhos que orientou meu crescimento profissional.

Ao Dr. Elton Gloeden pelo apoio e colaboração constantes.

Aos amigos da sede da Cetesb que me apoiaram e entenderam minhas ausências, em especial ao querido Ricardo Anázia, responsável por um conhecimento tão especial.

Aos amigos conquistados nesta fase na Poli: Isabella, por longas horas ao telefone sanando dúvidas e trocando informações; Fernanda, pela força e incentivo; Isabel, pela companhia tão cedinho; André e Bruno por tanta paciência com meus cálculos. Espero tê-los por perto pelo resto da vida.

Aos amigos de todas as horas que contribuíram de uma forma ou de outra para que este trabalho fosse concluído.

À sempre amiga Savana (incluindo agora Nil, Júlia e Bruna) com todas as broncas e “chacoalhões”.

À Universidade de São Paulo, em especial ao Departamento de Minas e Petróleo da Escola Politécnica que tornaram este sonho possível. 


\section{RESUMO}

A Resolução do Conselho Nacional do Meio Ambiente - CONAMA n 273 evidenciou o problema do vazamento de combustível em postos de gasolina, há muito detectada por técnicos do órgão ambiental do Estado de São Paulo - a Companhia de Tecnologia de Saneamento Ambiental (Cetesb). Esta resolução resolve, principalmente, que: “A localização, construção, instalação, modificação, ampliação e operação de postos revendedores, postos de abastecimento, instalações de sistemas retalhistas e postos flutuantes de combustíveis dependerão de prévio licenciamento do órgão ambiental competente...”.

A gasolina brasileira possui na sua formulação $20 \%$ em média de etanol anidro (teor este que varia de acordo com a política energética momentânea) para aumentar a octanagem e reduzir a emissão de monóxido de carbono na atmosfera. No entanto, esta adição, aumenta sua solubilidade, uma vez que o etanol é solúvel em água e na própria gasolina, aumentando também a mobilidade do contaminante, conseqüentemente dos compostos BTEX (benzeno, tolueno, etilbenzeno, xilenos) e hidrocarbonetos monoaromáticos - altamente nocivos à saúde humana.

O município de Guarulhos é uma importante cidade da Região Metropolitana do Estado de São Paulo. Tanto seu pólo industrial - altamente diversificado, quanto a presença do Aeroporto Internacional de São Paulo, com a passagem de cerca de 100 mil pessoas por dia, conferem a cidade grande importância na economia do Estado.

A água subterrânea é a única fonte de água potável para consumo de grande parte dos bairros da cidade. No entanto, a cidade apresenta um grande percentual de áreas contaminadas por postos de combustíveis. Considerando a população da cidade é possível perceber que um grande número de pessoas convive diariamente com o problema de áreas passíveis de contaminação por hidrocarbonetos.

Tendo em vista a problemática acima exposta, este trabalho visa o levantamento dos dados de contaminação das águas subterrâneas, bem como de solos, pela atividade de postos de gasolina, evidenciando o impacto destas contaminações sobre a população da cidade de Guarulhos. Para tanto, realizou-se estudo na documentação existente nos processos de licenciamento ambiental, bem como de reclamação da população, existentes na Cetesb Agência Ambiental de Guarulhos, quanto aos aspectos geológicos, hidrogeológicos, técnicos e comunitários quanto à evolução das plumas de contaminação e a discussão das remediações aplicáveis e/ou já aplicadas.

Para o desenvolvimento desta pesquisa foram utilizados os laudos de análises, os estudos de passivo ambiental e os demais documentos constantes nos processos de licenciamento, apresentados por estes estabelecimentos à Cetesb, visando à obtenção das licenças a que faz referência a Resolução CONAMA nº 273.

As diferenças existentes quanto à condutividade hidráulica e a ocorrência de anisotropia são determinantes quando se trata da direção e velocidade da migração da pluma de contaminação nos diversos tipos de solo. São estas diferenças, alguns dos fatores que, somadas a dispersão e a difusão, condicionam o comportamento dos contaminantes no solo (TRESSOLDI, 2002).

É importante comentar que o gerenciamento de uma contaminação envolve a remoção de fase livre de produto, a investigação da contaminação remanescente, a avaliação e gerenciamento de riscos e finalmente as medidas de remediação, no entanto, nenhum dos 5 casos estudados apresentou, até junho de 2006, um projeto de remediação, embora todos já estejam removendo a fase livre de contaminante.

Este trabalho elaborou propostas conceituais de remediação, com a utilização de desadsorção térmica em conjunto com atenuação natural, implantação de sistemas de Air Strippers e extração multifásica - MPE. Foram escolhidos dois casos dentre os analisados, pois, até outubro de 2006, ainda não havia sido apresentado nenhum projeto para descontaminação 
destas áreas e, um dos empreendimentos, sequer não havia realizado reforma, o que facilita a remoção do solo para uma melhor remediação.

Palavras-chave: áreas contaminadas, gasolina, remediação, Guarulhos. 


\begin{abstract}
The Resolution of the Nacional Environment Council - CONAMA n 237 made obviously the problem concerning fuel leak in gas stations, already detected by technicians of the environmental organ of São Paulo State - Company of Environmental Sanitation Technology (Cetesb). This Resolution establishes that: "the location, construction, installation, modification, enlargement and operation of gas stations, fuel suppliers, fuel retailers and floating gas stations, will depend on the previous licensing by the competent environmental organ...”

The Brazilian gasoline contains approximately $20 \%$ of ethanol anhydrous (the content varies according to the energetic politics) to increase the octane and reduce the emission of carbon monoxide in the atmosphere. Nevertheless, this addition increases its solubility, because the ethanol is soluble in both water and gasoline, increasing the mobility of the contaminant, thus the BTEX compounds (benzene, toluene, ethyl benzene, and xylene) and Monocyclic Aromatic Hydrocarbons - highly toxic to the human health.

The municipality of Guarulhos is a very important city of the Metropolitan Region of São Paulo State, due to the diversified industry and the presence of the São Paulo International Airport, where approximately 100 thousand people pass daily.

The groundwater is the only source of potable water in many districts of the city. However, there are many contaminated areas by gasoline leaking. So far a great number of people live at areas that are susceptible to the contamination by hydrocarbons compounds.

Considering this problem, this research consists in collect data about contaminated groundwater and soil by gas stations operations, verifying the impact of contamination on the population. An investigation of the environment licenses was carried out, as well as the citizens complaints at Cetesb - The environmental Agency in Guarulhos, about geological, hydro geological, technical and community aspects related to the plumes of contamination and their evolution and to discuss the appropriate remedy.

To develop this research, the analysis certificate, environmental damage and other documents by the licensing process presented at Cetesb, have been used, to obtain the approval according CONAMA n ${ }^{\circ} 273$.

The differences about hydraulic conductivity and anisotropy are determinant when talking about direction and speed of the contamination plume migration in different soils. These differences, summed to dispersion and diffusion, condition the behavior of contaminants in the soil (TRESSOLDI, 2002).

It is important to know that manage a contamination involves removing the free phase of the product, investigating the contamination left, evaluating and managing the risks and measuring remediation. However, neither one of the five cases presented, until June 2006, a project of treatment, even though all of them are removing the free of contaminants phase.

This research elaborated proposals concepts of remediation, using thermal desorption with natural attenuation, implantation of the systems Air Strippers and multiphase extraction MPE. Two cases were chosen among all the situations analyzed, because until October 2006 no project was presented to de-contaminate those areas, and in one case, no reform was done, what facilitates removing the soil to a better remediation.
\end{abstract}

Key word: contaminated areas, gasoline, remediation, Guarulhos. 


\section{LISTA DE ABREVIATURAS E SIGLAS}

ACBR

AIIPA

AIIPM-

API

ASTM

BRP

BTEX

CMEA

Cetesb

CONAMA

COV

CSAO

DCE

DRO

EPA

GNV

GRO

HDP

HPA

LIE

LNAPL

MPE

MTBE

$\mathrm{Na}$

NABR

$\mathrm{PAH}$

PCE

PCB

PGR

POA
Ações Corretivas com Base no Risco

Auto de Infração - Imposição de Penalidade de Advertência

Auto de Infração - Imposição de Penalidade de Multa

American Petroleum Institute

American Society for Testing and Materials

Barreiras reativas permeáveis

Benzeno, tolueno, etilbenzeno e xilenos

Concentração Meta Baseada no Risco

Companhia de Tecnologia de Saneamento Ambiental

Conselho Nacional do Meio Ambiente

Compostos orgânicos voláteis

Caixa separadora água e óleo

Dicloroeteno

Resíduos orgânicos provenientes do diesel

Environmental Protection Agency

Gás Natural Veicular

Resíduos orgânicos provenientes da gasolina

Hidrocarbonetos derivados de petróleo

Hidrocarbonetos policíclicos aromáticos

Limite Inferior de Explosividade

Light non-aqueous phase liquids, ou seja, fase líquida imiscível leve ou menos densa que a água

Extração multifásica

Éter metil terc-butílico

Nível d’água

Níveis de Avaliação Baseados no Risco

Hidrocarbonetos policíclicos aromáticos

Tetracloroetileno

Bifenilas policloradas

Plano de Gerenciamento de Risco

Processo Oxidativo Avançado 
RBCA

RBSL

RMSP

SAO

SAAE

SMA

SSTL's

SVE

SVOC

TAC

TCE

TPH

USEPA

VOC

UV
Risk Based Corrective Action, ou ainda, Ações Corretivas com Base no Risco

Risk-Based Screening Level

Região Metropolitana de São Paulo

Separação água-óleo

Serviço Autônomo de Água e Esgoto

Secretaria do Meio Ambiente

Specific Site Target Levels

Sistema de extração de vapores do solo

Compostos orgânicos semi-voláteis

Termo de Ajuste de Conduta

Tricloroeteno

Hidrocarbonetos totais de petróleo

Agência de Proteção Ambiental dos Estados Unidos da América

Compostos orgânicos voláteis

Radiação ultra-violeta 


\section{LISTA DE FIGURAS}

Figura 1 - Diagrama esquemático de uma indústria desativada ............................................ 02

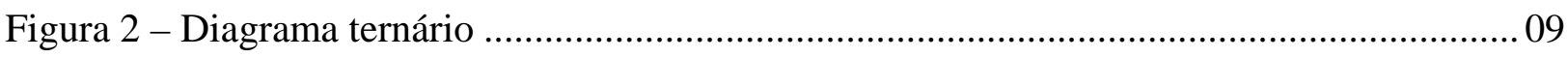

Figura 3 - Fases distintas de LNAPL após um vazamento em um aqüífero............................... 16

Figura 4 - Definição de molhabilidade com base no ângulo de contato ...................................... 23

Figura 5 - Conceito de pressão capilar em um capilar............................................................. 25

Figura 6 - Ascensão da água em tubos capilares de diâmetros diferentes ................................. 26

Figura 7 - Esquema mostrando a elevação capilar para diferentes gargantas de poros ............... 28

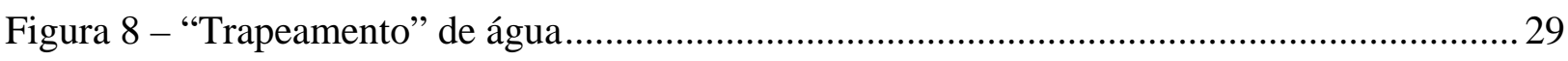

Figura 9 - Distribuição de áreas contaminadas por atividade ................................................ 31

Figura 10 - Mapa da Região Metropolitana de São Paulo .......................................................... 33

Figura 11 - Ações emergenciais e de controle institucional ...................................................... 38

Figura 12 - Processos de remediação utilizados ....................................................................... 39

Figura 13 - Fluxograma de decisão quanto à tecnologia de remediação a ser escolhida............. 43

Figura 14 - Esquematização de um Air Stripper de coluna....................................................... 55

Figura 15 - Esquematização de um Low Profile Air Stripper ................................................. 56

Figura 16 - Processo de transporte no adsorvente ................................................................. 59

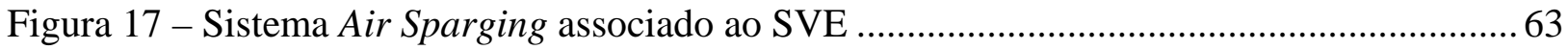

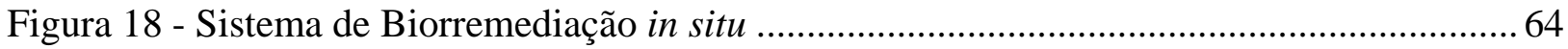

Figura 19 - Sistema de Extração de Vapores ............................................................................... 68

Figura 20 - Representação esquemática de Barreiras reativas permeáveis (BRP)..................... 70

Figura 21 - Representação esquemática de fitodegradação de poluentes................................... 72

Figura 22 - Esquema de desadsorção térmica móvel............................................................ 77

Figura 23 - Município de Guarulhos - demarcação aproximada dos postos analisados .............. 81

Figura 24 - Imagem de satélite do município de Guarulhos .................................................... 82

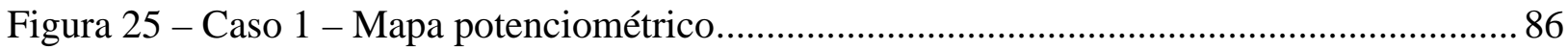

Figura 26 - Caso 1 - Delimitação da pluma de contaminação ................................................. 90

Figura 27 - Caso 1 - Localização dos tanques após a reforma ................................................. 91

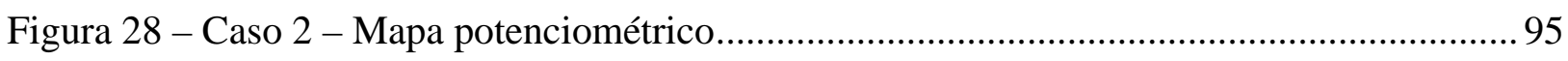

Figura 29 - Caso 2 - Delimitação da pluma de contaminação .................................................. 100

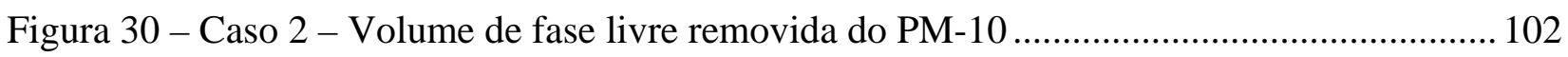

Figura 31 - Caso 3 - Mapa potenciométrico, delimitação da pluma de contaminação e entorno105 


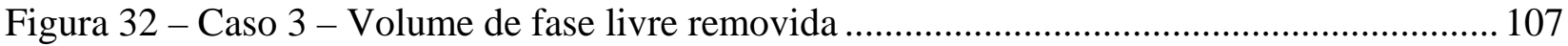

Figura 33 - Caso 3 - Mapa potenciométrico, delimitação da pluma de contaminação e entorno110

Figura 34 - Caso 4 - Mapa potenciométrico e instalação dos poços de monitoramento ..............116

Figura 35 - Caso 4 - Delimitação da pluma de contaminação (dezembro de 2005) .................... 122

Figura 36 - Caso 4 - Volume de fase livre removida ............................................................ 124

Figura 37 - Caso 5 - Mapa potenciométrico e instalação dos poços de monitoramento.............. 128

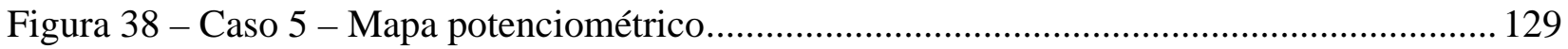

Figura 39 - Caso 5 - Delimitação da pluma de contaminação ................................................... 131

Figura 40 - Caso 5 - Delimitação da pluma de contaminação .................................................. 132

Figura 41 - Caso 5 - Delimitação da pluma de contaminação .................................................. 133

Figura 42 - Caso 5 - Delimitação da pluma de contaminação ................................................... 134

Figura 43 - Caso 5 - Fluxo subterrâneo observado em fevereiro de 2002 ................................. 136

Figura 44 - Caso 3 - Ampliação da delimitação da pluma de contaminação .............................. 145

Figura 45 - Caso 4 - Ampliação da delimitação da pluma de contaminação .............................. 148 


\section{LISTA DE SÍMBOLOS}

\begin{tabular}{|c|c|}
\hline$\left(\mathrm{C}_{2} \mathrm{H}_{5}\right)_{4} \mathrm{~Pb}$ & tetraetilchumbo \\
\hline$s_{i}^{e f}$ & solubilidade efetiva do composto $i$ na mistura \\
\hline$X_{i}$ & fração molar do composto $i$ na mistura \\
\hline$S_{i}$ & solubilidade do composto puro $i$ na temperatura $t$ \\
\hline $\mathrm{C}_{6} \mathrm{H}_{6}$ & benzeno \\
\hline $\mathrm{C}_{6} \mathrm{H}_{5} \mathrm{CH}_{3}$ & tolueno \\
\hline $\mathrm{C}_{6} \mathrm{H}_{5} \mathrm{C}_{2} \mathrm{H}_{5}$ & etilbenzeno \\
\hline $\mathrm{C}_{6} \mathrm{H}_{4}\left(\mathrm{CH}_{3}\right)_{2}$ & o-xileno \\
\hline pi & pressão de vapor do composto $i$ \\
\hline$p_{i}^{e f}$ & pressão de vapor efetiva do composto $i$ \\
\hline$X_{i}$ & fração molar do composto i na mistura \\
\hline$P_{i}$ & pressão de vapor do composto puro $i$ na temperatura $t$ \\
\hline $\mathrm{O}_{2}$ & oxigênio \\
\hline $\mathrm{NO}_{3}^{-}$ & nitrato \\
\hline $\mathrm{Fe}(\mathrm{III})$ & íon de ferro trivalente \\
\hline $\mathrm{SO}_{4}^{--}$ & sulfato \\
\hline$K$ & condutividade hidráulica \\
\hline$\eta_{e}$ & porosidade efetiva \\
\hline$\frac{\partial h}{\partial l}$ & gradiente hidráulico \\
\hline$F$ & fluxo de massa \\
\hline$D$ & coeficiente de difusão \\
\hline$\frac{\partial C}{\partial x}$ & gradiente de concentração \\
\hline$q$ & densidade de fluxo \\
\hline$K$ & condutividade hidráulica \\
\hline$\theta$ & teor de água \\
\hline$\psi m$ & estado energético \\
\hline$H$ & potencial total de água no solo \\
\hline$S$ & saturação \\
\hline
\end{tabular}


$V_{f}$

$V_{t}$

$P_{c}$

$P_{n w}$

$P_{w}$

$P_{o}$

$P_{w}$

$\sigma_{\text {ow }}$

$\theta$

$r$

$\sigma_{\text {ws }}$

$\sigma_{o s}$

$h_{c}$

$\sigma$

$\theta$

$\gamma$

$r$

hc

$\eta$

$d_{10}$

$P_{c}$

$P_{n w}$

$P_{\text {w }}$

C

$I R$

FC

AF

EF

$E D$

$B W$ volume de fluido nos poros

volume total de poros

pressão capilar

pressão do fluido não-molhante

pressão do fluido molhante

pressão do óleo

pressão da água

tensão interfacial óleo-água

ângulo de contato

raio do tubo

tensão interfacial água-sólido

tensão interfacial óleo-sólido

altura da ascensão capilar

tensão interfacial

ângulo de contato

peso específico da água

raio da garganta dos poros

altura da ascensão capilar

porosidade efetiva

diâmetro efetivo dos grãos

pressão capilar

pressão do fluido não-molhante

pressão do fluido molhante

concentração média à qual a população receptora pode ser exposta num período especificado

taxa de assimilação de um meio no ambiente (e.g., quantidade de água consumida por dia)

fração de assimilação que está contaminada pela área

fração de contaminantes no meio que é absorvida pelo organismo

freqüência de exposição

duração da exposição

peso corpóreo 
AT

$L A D D$

SF

HQ

$A D D$

AT

C

$U R F$

EF

$E D$

AT

HQ

$R f C$

HI

$H Q$

$\mathrm{H}_{2} \mathrm{O}_{2}$

$\mathrm{KMnO}_{4}$

$\mathrm{O}_{3}$

OD período no qual a exposição é calculada

dose diária média para expectativa de vida (70 anos por convenção)

fator de ingestão oral

quociente de perigo não-cancerígeno

dose diária média

período no qual a exposição é calculada

concentração média à qual a população receptora pode ser exposta num período especificado

fator de risco por unidade de inalação

freqüência de exposição

duração da exposição

período no qual a exposição é calculada

quociente de perigo não-cancerígeno

concentração de referência de inalação

índice de perigo

quociente de perigo não-cancerígeno

peróxido de hidrogênio

permanganato de potássio

ozônio

oxigênio dissolvido 


\section{LISTA DE TABELAS}

Tabela 1 - Solubilidade dos compostos BTEX a $25{ }^{\circ} \mathrm{C}$ em água............................................ 10

Tabela 2 - Distribuição das fases do contaminante (gasolina com 24\% de etanol).................... 17

Tabela 3 - Altura capilar visível em materiais não consolidados ............................................. 28

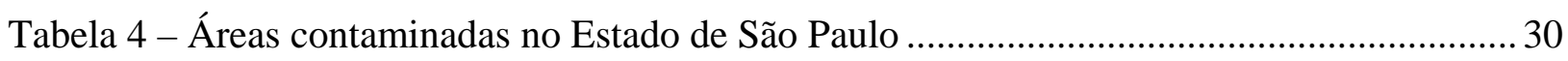

Tabela 5 - Municípios da Região Metropolitana de São Paulo ................................................. 34

Tabela 6 - Caso 1 - Análise de água subterrânea (maio de 2003) ............................................ 87

Tabela 7 - Caso 1 - Análise de solo (maio de 2003) ................................................................. 87

Tabela 8 - Caso 1 - Análise de água subterrânea (maio de 2005) ............................................. 92

Tabela 9 - Caso 2 - Análise de solo (abril de 2003) ............................................................... 94

Tabela 10 - Caso 2 - Análise de água subterrânea (abril de 2003)...........................................94

Tabela 11 - Caso 2 - Análise de solo (fevereiro de 2005)...................................................... 99

Tabela 12 - Caso 2 - Análise de água subterrânea (fevereiro de 2005) .................................... 99

Tabela 13 - Caso 2 - Volume de combustível recuperado no PM-10 ........................................ 101

Tabela 14 - Caso 3 - Volume de combustível recuperado .......................................................... 106

Tabela 15 - Caso 3 - Análise de solo (abril de 2004) .................................................................. 108

Tabela 16a - Caso 3 - Análise de água subterrânea (abril de 2004).......................................... 109

Tabela 16b - Caso 3 - Análise de água subterrânea (abril de 2004).......................................... 109

Tabela 16c - Caso 3 - Análise de água subterrânea (abril de 2004).......................................... 109

Tabela 17 - Caso 3 - Análise de água subterrânea (mg/L) - março de 2006 .............................. 112

Tabela 18 - Caso 4 - Análises de água subterrânea (mg/L) - 2005 .......................................... 118

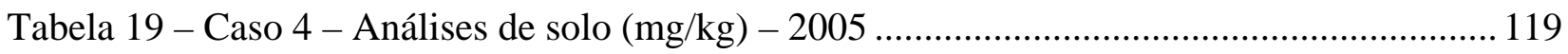

Tabela 20 - Caso 4 - Volume de combustível recuperado ....................................................... 124

Tabela 21 - Caso 5 - Análise de água subterrânea (fevereiro de 1998) ...................................... 130

Tabela 22 - Caso 5 - Análises de água subterrânea (fevereiro 2002) ........................................ 137

Tabela 23 - Caso 5 - Análises de água subterrânea (janeiro 2003) ............................................ 137

Tabela 24 - Caso 5 - Análises de solo (janeiro de 2003)......................................................... 138 


\section{SUMÁRIO}

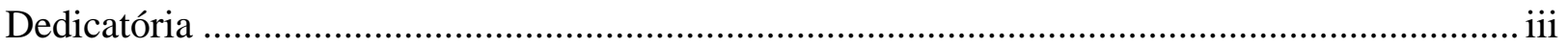

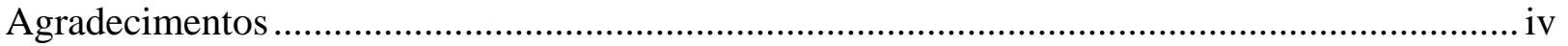

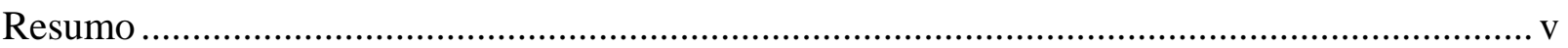

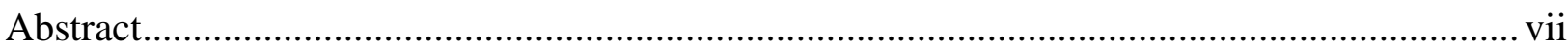

Lista de Abreviaturas e Siglas ........................................................................................... viii

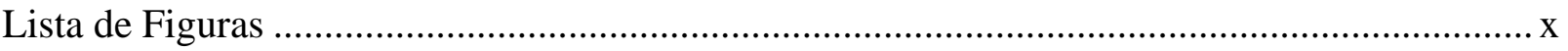

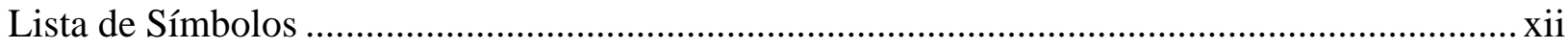

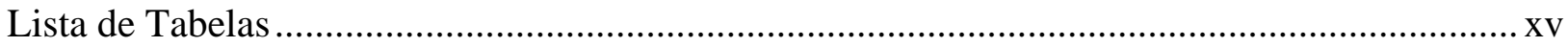

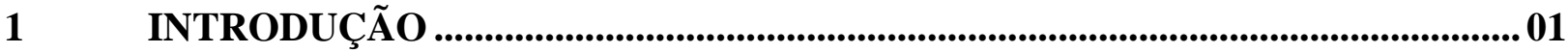

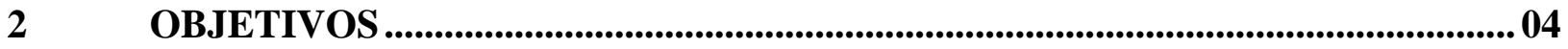

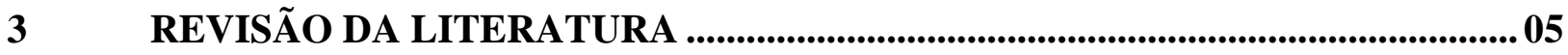

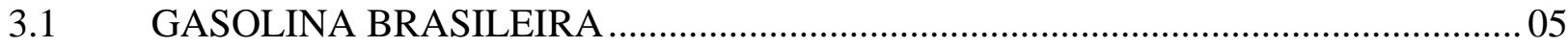

3.1.1 Hidrocarbonetos monoaromáticos - BTEX ....................................................... 05

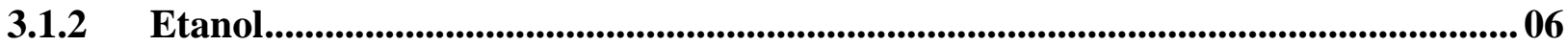

3.2 PROPRIEDADES FÍSICO-QUÍMICAS DOS HIDROCARBONETOS DA

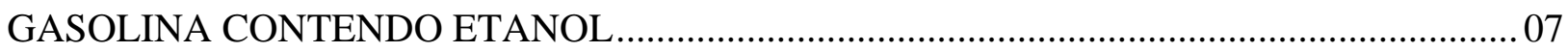

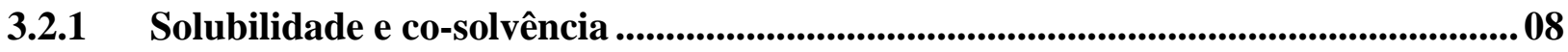

3.2.2 Pressão de vapor ............................................................................................................................ 10

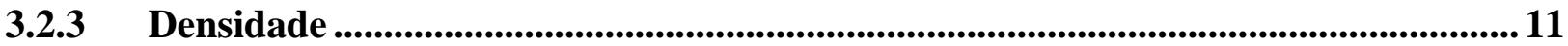

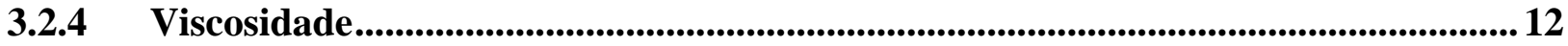

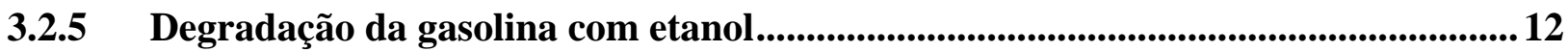

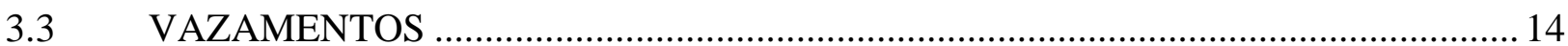

3.4 MECANISMOS DE TRANSPORTE OU MECANISMOS DE TRANSFERÊNCIA

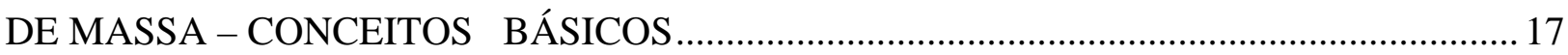

3.4.1 Advecção .............................................................................................................................................. 18

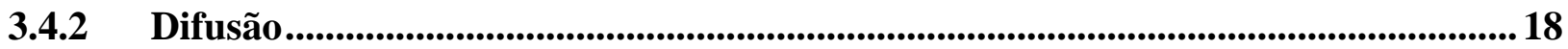

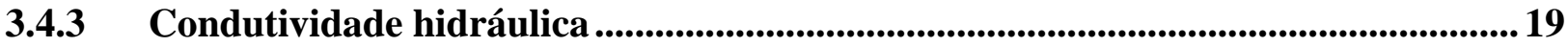




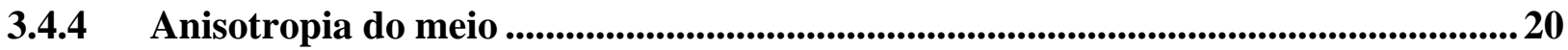

3.5 FLUXO MULTIFÁSICO - CONCEITOS BÁSICOS …......................................... 21

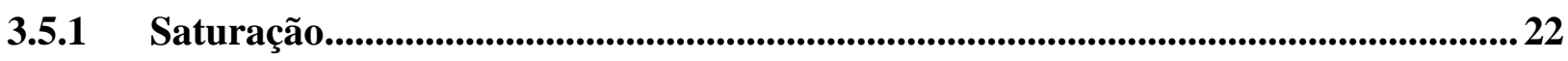

3.5.2 Molhabilidade e tensão interfacial........................................................................................ 22

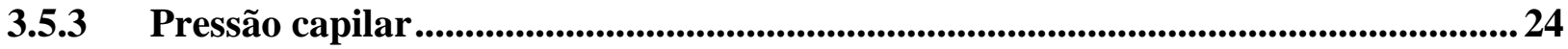

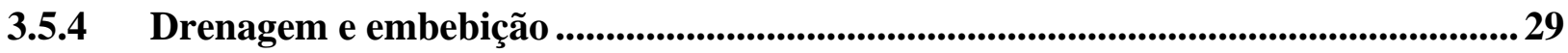

3.6 REGIÃO METROPOLITANA DE SÃO PAULO E $\quad$ O $\quad$ MUNICÍPIO DE

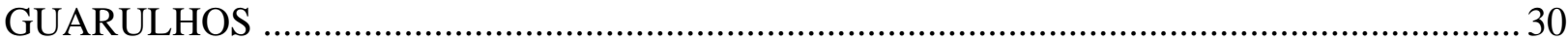

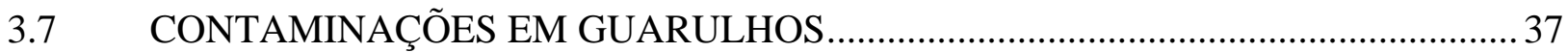

3.8 METODOLOGIAS QUE PRECEDEM A REMEDIAÇÃO ...................................... 39

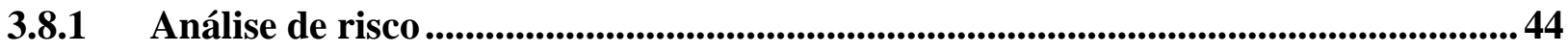

3.8.2 Ações Corretivas com Base no Risco - ACBR........................................................ 49

3.9 TECNOLOGIAS DE REMEDIAÇÃO COMUMENTE UTILIZADAS ...................... 52

3.9.1 Bombeamento e tratamento (Pump \& Treat) .................................................................. 52

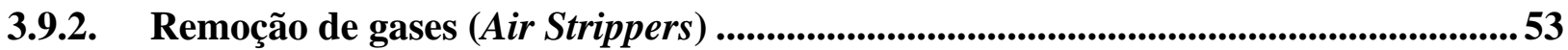

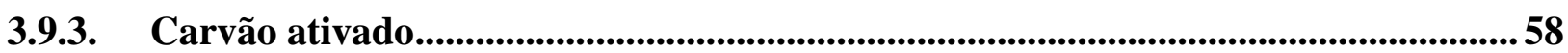

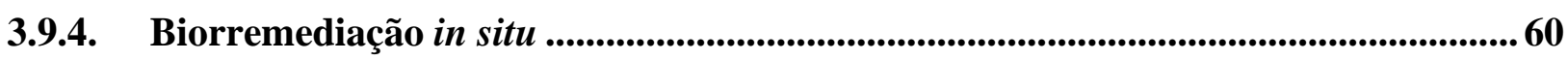

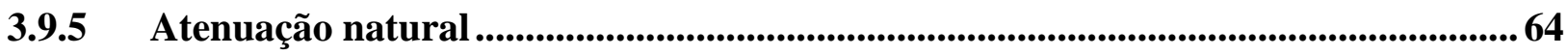

3.9.6 Injeção de melaço

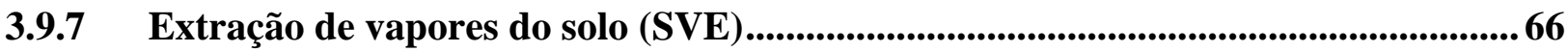

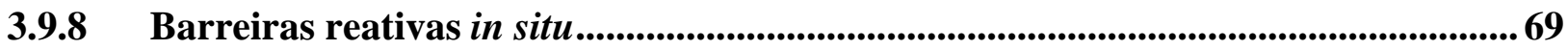

3.9.9 Extração multifásica (MPE) ou bioslusping ................................................................... 71

3.9.10 Fitorremediação ...................................................................................................... 71

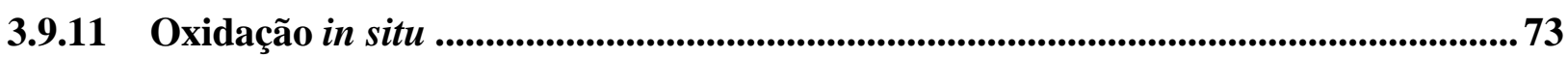

3.9.12 Sistema de recuperação de fase livre por skimming ............................................... 74

3.9.13 Desadsorção termal .............................................................................................................. 74

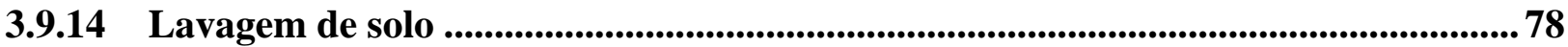

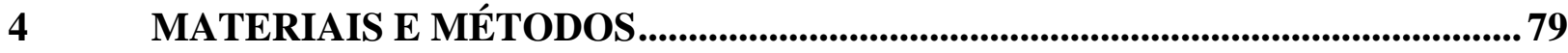

4.1 CASO 1 (

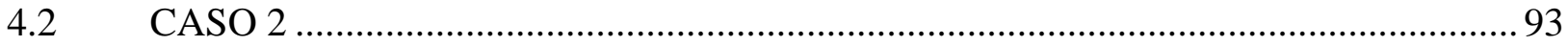

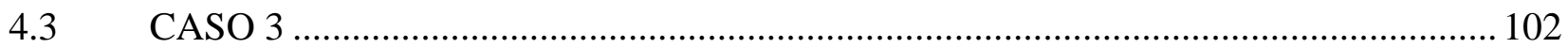

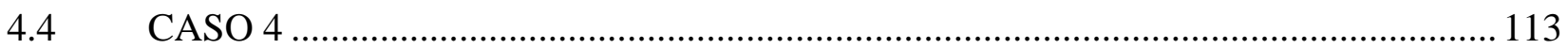

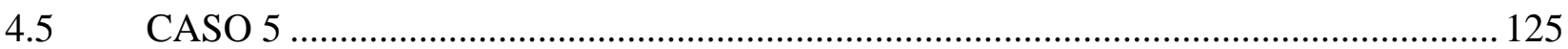


$6 \quad$ RESULTADOS: PROPOSTAS DE REMEDIAÇÃO .......................................... 142

Referências Bibliográficas

Anexos 


\section{INTRODUÇÃO}

A capacidade de autodepuração do solo, na qual se apoiava o conceito de que a disposição indiscriminada de resíduos domésticos e industriais era infindável, foi superestimada, como comprovado posteriormente e, somente a partir da década de 70, foi dedicada maior atenção a sua proteção (LOPES et al., 2001).

Este autor comenta que o conceito de "Áreas Contaminadas", como sendo um local cujo solo sofreu dano ambiental significativo, que o impede de assumir suas funções naturais ou legalmente garantidas, é relativamente recente na política ambiental dos países desenvolvidos, o mesmo ocorrendo no Brasil (MARKER et al., 1995 e 1998; SÁNCHEZ, 1998 e 2004).

A Figura 1, mostra um exemplo didático de áreas contaminadas por uma indústria desativada, ilustrando bem as fontes acima citadas. Logo, pode-se notar como fontes potencialmente perigosas:

1.vazamento de tanques enterrados e sistema de tubulação;

2.abandono de barris enferrujados com resíduos tóxicos;

3.percolação no solo, a partir de derramamento ou de antigos vazamentos; e

4.resíduos abandonados lançados sobre o solo.

Como conseqüências, ainda na Figura 1, percebem-se os seguintes cenários:

5.poluição do solo;

6.poluição de água subterrânea;

7.percolação de poluentes na água subterrânea em direção ao corpo d'água;

8. deposição de “metais pesados” no fundo do corpo d'água;

9. emissão de gases tóxicos;

10.efeitos na vegetação; e 
11.fluxo superficial de poluentes em direção ao corpo d’água.

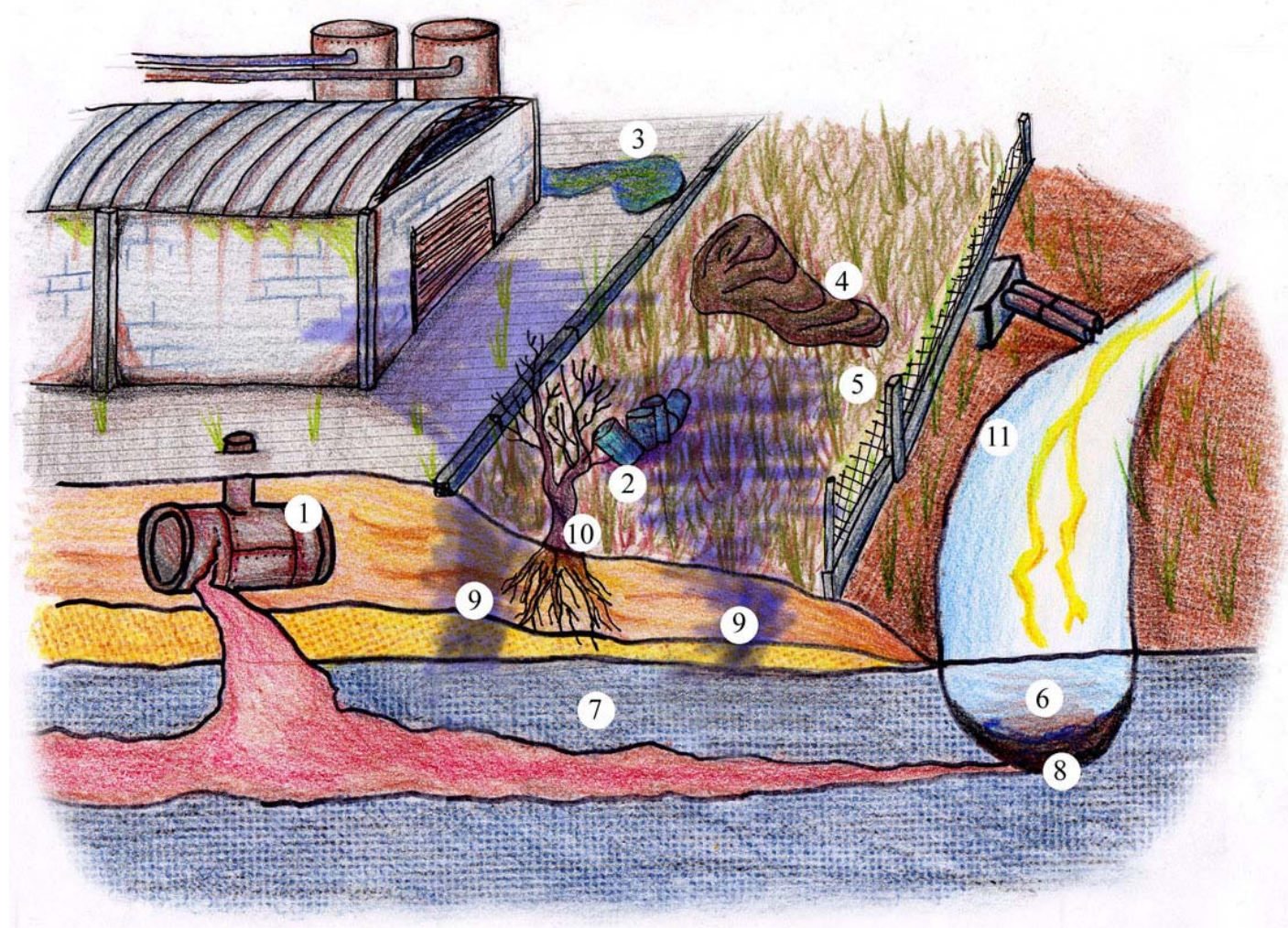

Figura 1 - Diagrama esquemático de uma indústria desativada Fonte: adaptado de Lopes et al., 2001

Ainda segundo Lopes et al. (2001), na Região Metropolitana de São Paulo (RMSP), principal região industrial do Brasil, antigas áreas industriais desativadas vêm sendo destinadas a novos usos. Esta forma indiscriminada de utilização destas áreas pode acarretar problemas já observados em outros países que tratam do assunto “Áreas Contaminadas” há mais tempo, como Alemanha, Reino Unido ou Bélgica (Região de Flandres).

A possível contaminação de aqüíferos ou reservas importantes de águas subterrâneas, que podem servir de abastecimento público e/ou domiciliar, é um grande risco para a segurança das pessoas e das propriedades, bem como à saúde pública e dos ecossistemas. Este problema é comumente notado no caso de vazamentos de gasolina ou outros líquidos voláteis ocorridos em postos de combustíveis e bases de distribuição, locais nos quais ficam armazenadas grandes quantidades de combustíveis que serão distribuídos aos postos ou outro 
tipo de empreendimento que necessite armazenamento, afirma Ferreira (2003).

Na década de 70 houve um aumento considerável no número de postos varejistas de combustíveis implantados no país. Os equipamentos, bem como as tubulações das referidas instalações, apresentavam tempo de vida útil estimado de 25 anos (FERREIRA, 2000). Isto posto, é natural que estes empreendimentos sejam considerados potencialmente poluidores, podendo ser geradores de acidentes ambientais (PENNER, 2000).

O Brasil possui mais de 30.000 postos de distribuição de combustíveis, sendo que no Estado de São Paulo estão instalados mais de 8.400 postos e aproximadamente 3.000 localizam-se na Região Metropolitana de São Paulo (CETESB, 2005). Levantamentos realizados por agências ambientais indicam que as áreas onde estão localizados estes postos de serviços são freqüentemente atingidas por vazamentos oriundos de tanques de armazenamento subterrâneos, que podem causar a contaminação do solo e das águas subterrâneas, além de contribuírem para o risco de explosões e incêndios.

A gasolina utilizada no Brasil apresenta um diferencial da maioria dos países: a adição do etanol. Este fato, torna inválida a aplicabilidade da maioria dos modelos já desenvolvidos no exterior, em contaminações por hidrocarbonetos para os casos encontrados no país.

Segundo Ferreira (2000), para que a tecnologia a ser escolhida apresente a eficácia esperada, faz-se necessária a compreensão das características químicas do contaminante e os mecanismos de transferência de massa que influenciam o sistema.

Este trabalho enfatiza as contaminações provenientes dos tanques de armazenamento de gasolina e álcool, embora os tanques de diesel e lubrificantes também sejam responsáveis por vários casos de contaminação, no postos de combustíveis do Brasil. Mas estes, não foram objetos deste estudo.

Ainda são poucas as contribuições que apresentam estudos dos efeitos deste tipo de contaminação em solos e águas subterrâneas brasileiras, conforme Oliveira (1992), Ferreira (2000) e Penner (2000). 


\section{OBJETIVOS}

Em função das peculiaridades do problema de contaminação por postos de combustíveis no Brasil, este trabalho teve por objetivos:

avaliar se ocorreram benefícios com a atuação do órgão ambiental do Estado de São Paulo - a Companhia de Tecnologia de Saneamento Ambiental (Cetesb), ou seja, se os incômodos (odores, verificação de fase livre) à população foram minimizados ou sanados;

avaliar o potencial poluidor dos vazamentos em postos de combustíveis, ou seja, avaliar como estes vazamentos podem agredir o aqüífero e se há possibilidade de recuperação, utilizando estudo de casos detectados na cidade de Guarulhos;

estudar a evolução das plumas de contaminação, bem como das remediações aplicáveis;

avaliar a eficácia dos métodos de remediação que estão sendo aplicados em diversos casos de contaminações por postos de gasolina;

analisar o impacto ambiental, principalmente no que tange ao consumo humano de água subterrânea e técnicas de remediação possíveis e aplicáveis; e

apresentar um plano conceitual de remediação para o caso que apresentar maior gravidade e que ainda não tenha apresentado proposta de remediação de acordo com o Cadastro de Áreas Contaminadas (disponível no endereço eletrônico da Cetesb). 


\section{REVISÃO DA LITERATURA}

\subsection{GASOLINA BRASILEIRA}

A gasolina é composta por uma mistura bastante complexa de hidrocarbonetos voláteis com 3 a 12 carbonos. As parafinas com cadeias ramificadas e cicloparafinas, hidrocarbonetos aromáticos e olefinas também são seus componentes majoritários (SAX \& LEWIS, 1987 apud FERREIRA, 2000). A composição final dependerá da origem do petróleo, do método de produção e dos processos de destilação, bem como dos compostos diversos que a ela são adicionados com a finalidade de melhorar o desempenho do motor, reduzir o desgaste mecânico e controlar a poluição do ar (FERREIRA, 2003).

A gasolina é um produto menos denso que a água, por isto, conforme afirmação de Ferreira, S. B. (2000) e Ferreira, S. M. (2003), é classificada como light non-aqueous phase liquids (LNAPL), isto é, fase líquida imiscível leve ou menos densa que a água.

\subsubsection{Hidrocarbonetos monoaromáticos - BTEX}

Conforme Ferreira (2000), os hidrocarbonetos monoaromáticos, benzeno, tolueno, etilbenzeno e os três xilenos orto, para e meta, chamados compostos BTEX, são constituintes da gasolina que, além de serem percebidos em concentrações significativas, têm maior solubilidade em água e, portanto, são os contaminantes que primeiro poluem o lençol freático, assinala Penner (2000). Estes compostos são altamente nocivos à saúde, principalmente como 
depressores do sistema nervoso central. A exposição contínua ao benzeno pode causar câncer, leucopenia, vertigens, tremores entre outros distúrbios (FERREIRA e PENNER, 2000).

Devido também à dificuldade no sentido de caracterizar um vazamento de gasolina, uma vez que não é possível um teste individual para cada um dos seus componentes (OLIVEIRA, 1992) os BTEX são utilizados como parâmetros para quantificar uma contaminação.

Em algumas situações, outros compostos adicionados à gasolina para aumentar a octanagem, ou seja, impulsionadores de octanas, como éter metil-tercbutílico e metanol são usados como indicadores de contaminação por gasolina. Porém, os que são comumente utilizados são os BTEX.

\subsubsection{Etanol}

Os tipos de etanol $\left(\mathrm{C}_{2} \mathrm{H}_{5} \mathrm{OH}\right)$ que interessam a este estudo são dois: álcool etílico hidratado que contém pequeno percentual de água e é utilizado no Brasil como combustível nos motores dos veículos a álcool e para fins industriais e o álcool etílico anidro, que é adicionado à gasolina para melhorar o desempenho desta e minimizar o desgaste do motor, conforme lembra Ferreira (2003).

A gasolina que é comercializada no Brasil sofre a adição de álcool etílico anidro em frações que podem variar de 20 a 24\%, no momento em que é transferida das bases aos caminhões-tanque (FERREIRA, 2000). Segundo Ferreira (2003), o uso deste composto oxigenado adicionado à gasolina serve ainda para aumentar a octanagem e reduzir a emissão de monóxido de carbono para a atmosfera .

Em alguns países, para aumentar a octanagem da gasolina, ainda é utilizada a adição 
do tetraetilchumbo, $\left(\mathrm{C}_{2} \mathrm{H}_{5}\right)_{4} \mathrm{~Pb}$, o que a torna conhecida como gasolina etílica ou gasolina com chumbo. No entanto, além do dióxido de carbono e da água, o motor lança para a atmosfera outras substâncias, que são produtoras de fumos, ou muito tóxicas; "hidrocarbonetos não queimados, monóxido de carbono, óxidos de nitrogênio e, a partir da gasolina com teor de chumbo, vários compostos de chumbo são lançados diariamente na atmosfera...” (MORRISON e BOYD, 1973). Porém, no Brasil, a adição de compostos de chumbo foi totalmente eliminada. Nos Estados Unidos da América, por exemplo, desde que o uso de MTBE (éter metil terc-butílico) como aditivo foi vetado, devido ao fato de comprometer a qualidade da água subterrânea, o etanol foi escolhido como a principal alternativa.

Como já citado, o etanol pode ser encontrado em postos de serviços tanto aditivado à gasolina quanto como álcool combustível. É importante lembrar que uma contaminação, resultante de um vazamento de gasolina com álcool, pode ficar muito pior se, contíguo a ele, houver um vazamento de álcool combustível.

O uso de álcool combustível é muito mais recente que o uso da gasolina, porém o álcool hidratado é mais corrosivo e pode perfurar o tanque em um intervalo de tempo muito menor que o tempo que leva a gasolina para causar a mesma corrosão.

3.2 PROPRIEDADES FÍSICO-QUÍMICAS DOS HIDROCARBONETOS DA GASOLINA CONTENDO ETANOL, QUE INTERESSAM A ESTE ESTUDO

Para facilitar a compreensão dos movimentos da gasolina em subsuperfície e em água é necessário o entendimento de algumas propriedades físico-químicas que influenciam diretamente na mobilidade do contaminante. Este conhecimento, além de facilitar o entendimento, propicia melhor escolha do processo de remediação. 


\subsubsection{Solubilidade e co-solvência}

Conforme Russel (1981), a solubilidade de um soluto em um dado solvente é definida como a concentração daquele soluto na sua solução saturada. No entanto, Ferreira (2000) afirma que outros fatores podem influenciar na solubilidade de um determinado composto químico, são eles: temperatura, salinidade, matéria orgânica dissolvida e cossolventes.

A solubilidade nas misturas é uma das mais importantes propriedades que afetam o transporte dos compostos químicos no meio ambiente e é determinada pela Lei de Raoult:

$$
s_{i}^{e f}=X_{i} S_{i}
$$

Onde:

$$
\begin{aligned}
& s_{i}^{e f}=\text { solubilidade efetiva do composto i na mistura }(\mathrm{mg} / \mathrm{L}) ; \\
& X_{i}=\text { fração molar do composto i na mistura; e } \\
& S_{i}=\text { solubilidade do composto puro i na temperatura } \mathrm{t}(\mathrm{mg} / \mathrm{L}) .
\end{aligned}
$$

A gasolina pura é imiscível na água, no entanto, o etanol é completamente miscível na gasolina e na água. Desta forma, quando ocorre da gasolina adicionada de etanol misturar-se a água, esta particiona-se dentro da fase aquosa, aumentando a solubilidade de BTEX e reduzindo a tensão interfacial da gasolina-água. Segundo Ferreira et al. (2004), o sistema final seria composto de uma fase de água e álcool e alguma gasolina dissolvida e uma fase de gasolina e álcool com um pouco de água dissolvida. Assim, com uma proporção suficientemente alta de etanol em um sistema, a gasolina e a água tornam-se completamente miscíveis e uma fase única será desenvolvida.

O diagrama pseudoternário abaixo, explica o agrupamento de componentes múltiplos 
como um pseudocomponente. Cada ápice do triângulo representa 100\% do componente simples, neste caso, representados água, gasolina e etanol. A região cinza, indica o limite onde dois componentes juntos formam uma só fase no sistema. A curva que separa a região 1 da região 2, chama-se curva binodal. Acima da curva binodal, os três compostos - água, etanol e gasolina - encontram-se em uma única fase, desde que a percentagem de etanol exceda 70 \% (OLIVEIRA, 1997).

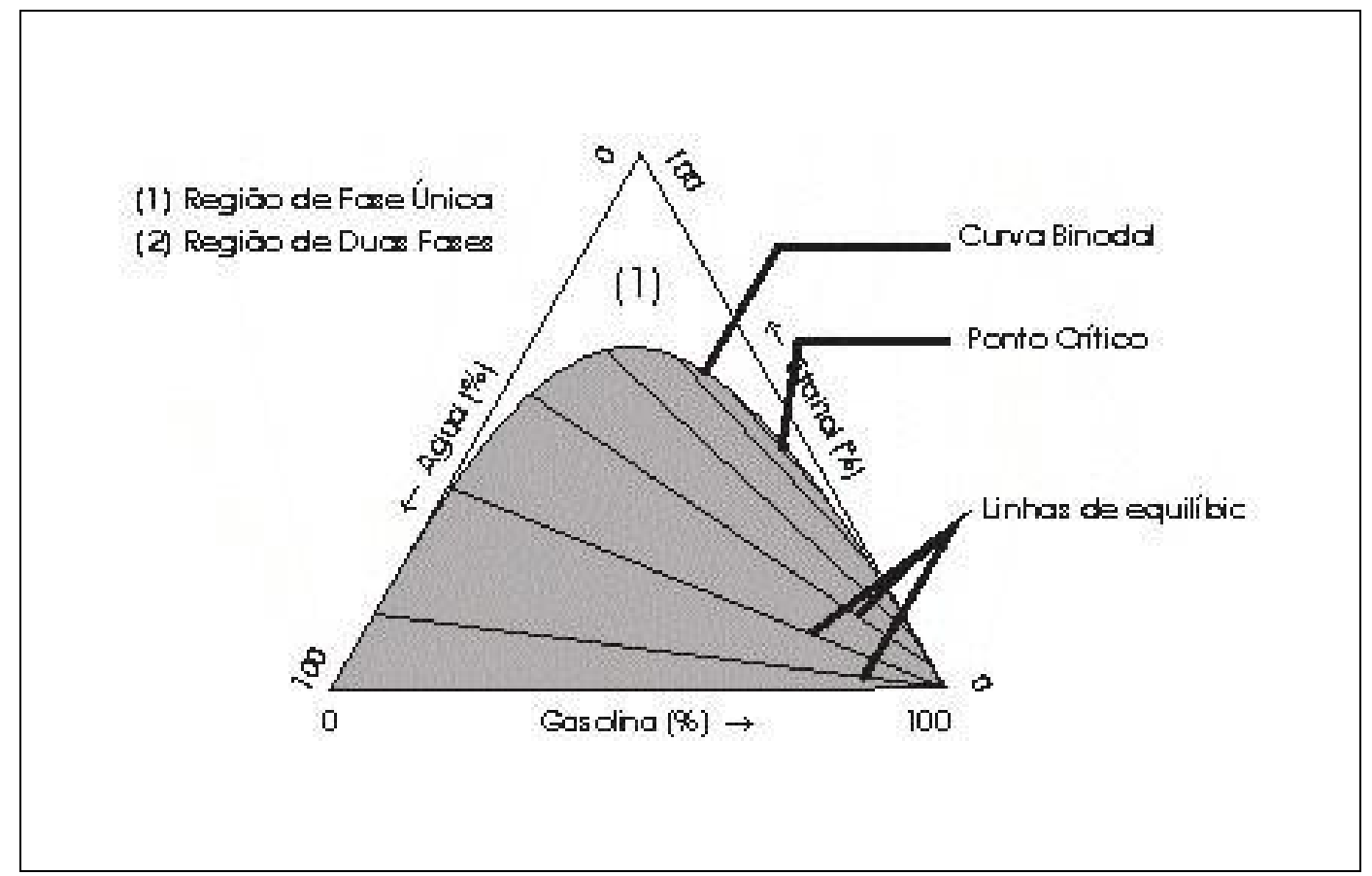

Figura 2 - Diagrama ternário

Fonte: adaptado de Oliveira (1997)

Os compostos químicos presentes na gasolina possuem diferentes valores de solubilidade em água. O etanol, entre outros, são altamente solúveis, já os BTEX são levemente solúveis, conforme apresenta a Tabela 1. 
Tabela 1 - Solubilidade dos compostos BTEX a $25{ }^{\circ} \mathrm{C}$ em água

\begin{tabular}{cccc}
\hline Composto & Fórmula & Peso molecular $\mathbf{( g / m o l )}$ & Solubilidade (mg/L) \\
\hline Benzeno & $\mathrm{C}_{6} \mathrm{H}_{6}$ & 78 & 1780 \\
Tolueno & $\mathrm{C}_{6} \mathrm{H}_{5} \mathrm{CH}_{3}$ & 92 & 515 \\
Etilbenzeno & $\mathrm{C}_{6} \mathrm{H}_{5} \mathrm{C}_{2} \mathrm{H}_{5}$ & 106 & 150 \\
o-xileno & $\mathrm{C}_{6} \mathrm{H}_{4}\left(\mathrm{CH}_{3}\right)_{2}$ & 106 & 175 \\
\hline & & & Fonte: Morrison, 1973
\end{tabular}

Segundo Oliveira (1992), o benzeno presente em uma gasolina normal sem chumbo, quando em contato com água, pode apresentar uma concentração em água da ordem de 30 mg/L, enquanto que, se for uma gasolina contendo etanol, a concentração em água ultrapassa 1.700 mg/L. Este fenômeno é chamado de co-solubilidade. Co-solvência é o elevado aumento da solubilidade dos hidrocarbonetos em contato com a água, caracterizado, por exemplo, pela adição de solventes hidrofílicos à gasolina (PENNER, 2000).

Desta forma, o etanol propicia aos compostos BTEX uma maior solubilidade em água, aumentando assim sua mobilidade, permitindo que eles se espalhem mais rapidamente pela subsuperfície (FERREIRA, S. B., 2000; FERREIRA, S. M., 2003; MOERI, COELHO e MARKER, 2004)

\subsubsection{Pressão de vapor}

A pressão de vapor pi é a pressão exercida pelo vapor de um composto orgânico puro (líquido ou sólido) com seu próprio vapor a uma determinada temperatura. A pressão de vapor é usada para estimar a taxa de emissão de compostos químicos voláteis do solo e da água para a fase vapor. Trata-se de um dos parâmetros utilizados para medir a volatilidade de um contaminante, esteja ele no solo ou água (FERREIRA, 2003).

Segundo Ferreira (2000) a taxa de volatilização de um composto orgânico no solo é 
afetada também por outros fatores: solubilidade do contaminante em água, concentração do contaminante no solo, características de sorção do solo, difusão na fase aquosa e na fase vapor, temperatura, conteúdo de água, conteúdo de carbono orgânico, teor de argila, porosidade, massa específica do solo e movimento do ar atmosférico, dentre outros.

A pressão de vapor de um determinado composto, conforme Ferreira (2003), é menor em misturas do que a do composto puro e pode ser representada por outra forma da Lei de Raoult:

$$
p_{i}^{e f}=X_{i} P_{i}
$$

Onde:

$$
\begin{aligned}
& p_{i}^{e f}=\text { pressão de vapor efetiva do composto i (atm); } \\
& X_{i}=\text { fração molar do composto i na mistura; e } \\
& P_{i}=\text { pressão de vapor do composto puro i na temperatura t } \\
& (\mathrm{atm}) .
\end{aligned}
$$

\subsubsection{Densidade}

Esta é uma propriedade importante para entender o comportamento do contaminante, pois, no caso da gasolina, é sua densidade menor que a da água que a faz flutuar sobre a água no caso de um vazamento (FERREIRA, 2000).

Ela é definida como massa do fluido por unidade de volume. O valor da densidade da gasolina com álcool é 0,700 g/ml, ou seja, sempre inferior à densidade da água que é de 0,998 g/mL a $15^{\circ} \mathrm{C}$ (API, 1996; FERREIRA, 2003). Assim, pode-se concluir que quando um vazamento atinge as águas subterrâneas haverá uma fase livre sobre a água, facilmente 
retirável.

\subsubsection{Viscosidade}

É a medida da resistência de um fluido para escoar, conforme lembra Ferreira (2000). As oscilações de temperatura podem influenciar diretamente na viscosidade, ou seja, um aumento de temperatura diminui a viscosidade e pode favorecer a mobilidade da gasolina no solo. Quando o etanol é adicionado à gasolina, também ocorre a diminuição da sua viscosidade (FERREIRA, 2003). Esta propriedade é importante para que seja definido o fluxo provável do contaminante.

\subsubsection{Degradação da gasolina com etanol}

Quando ocorre um vazamento, uma das primeiras conseqüências é a percepção de condições anaeróbias, devido os níveis crescentes de respiração microbiana nesta zona. Sob condições anaeróbias, conforme Barker et al. (1991), a degradação que ocorre com os BTEX, segue a suscetibilidade xileno>tolueno>benzeno.

Para a biodegradação dos hidrocarbonetos é essencial uma reação de reduçãooxidação, em que o hidrocarboneto é oxidado (doador de elétron) e um aceptor de elétron é reduzido. Existem diferentes compostos que podem agir como aceptores de elétron, entre eles o oxigênio $\left(\mathrm{O}_{2}\right)$, o nitrato $\left(\mathrm{NO}_{3}{ }^{-}\right)$, os óxidos de $\mathrm{Fe}(\mathrm{III})$, o sulfato $\left(\mathrm{SO}_{4}{ }^{{ }}\right)$, entre outros. Bactérias aeróbicas usam oxigênio molecular como aceptor de elétron e bactérias anaeróbicas usam 
outros compostos, tais como nitrato $\left(\mathrm{NO}_{3}{ }^{-}\right)$, óxidos de $\mathrm{Fe}(\mathrm{III})$, sulfato $\left(\mathrm{SO}_{4}{ }^{\circ}\right)$ como aceptor de elétron. O oxigênio é o aceptor preferencial, pois os microorganismos ganham mais energia nas reações aeróbicas. Dentre os aceptores de elétron das reações anaeróbicas, o nitrato é um dos íons mais encontrados em águas naturais, ocorrendo geralmente em baixos teores nas águas superficiais, mas podendo atingir altas concentrações em águas subterrâneas.

Segundo Barker et al. (1991) o álcool é degradado antes dos BTEX, consumindo assim, o oxigênio que seria utilizado na degradação aeróbia destes compostos. O etanol pode ainda ser tóxico e inibidor das bactérias que promovem a degradação dos BTEX.

Experimentos em testes de coluna demonstraram que a degradação dos BTEX foram afetadas negativamente pela degradação do etanol. Alvarez (2004) afirma que a degradação do etanol consome o oxigênio disponível no meio e exacerba o consumo dos receptores anaeróbios de elétrons, tais como os nitratos e sulfatos.

Acetato e ácidos graxos, produtos da degradação anaeróbia do etanol, podem reduzir o pH de um sistema. Esta redução, acentuada em sistemas pobremente tamponados, pode inibir a atividade microbiana, comprometendo o resto da degradação do etanol e de outros compostos.

Em colunas contendo BTEX e etanol, o segundo foi consumido antes dos compostos BTEX, conforme observado por Alvarez (2004). Esta degradação preferencial do etanol, bem como a diminuição do $\mathrm{pH}$ dos aqüíferos em virtude desta degradação, sugerem que o etanol pode dificultar a atenuação natural das plumas de BTEX. Este dado é importante pois mostra que o benzeno (mais tóxico recalcitrante dos BTEX) pode migrar para mais longe quando a gasolina contaminante contém etanol. 


\subsection{VAZAMENTOS}

Na década de 80, a população, através da percepção de odores ou mesmo visualização de fase livre de combustíveis em poços ou garagens subterrâneas, próximas a postos de gasolina, recorria ao órgão ambiental do Estado de São Paulo - a Cetesb, que tendo em vista o risco de incêndios e explosões tratavam estes casos como “atendimento de emergência”. Até novembro de 2000, a atividade de “comércio varejista de combustíveis” não era passível de licenciamento ambiental, uma vez que na legislação existente, não estava contemplada como fonte de poluição, o que tornava bastante difícil o controle destas contaminações.

Após o desastre ocorrido no México, em 1984, o número de reclamações de odores provenientes de possíveis vazamentos de combustíveis líquidos aumentou significativamente. Assim, os técnicos da Cetesb notaram a necessidade de uma legislação pertinente que proporcionasse um maior controle sobre o armazenamento subterrâneo de combustíveis e praticamente escreveram o texto que mais tarde tornou-se a Resolução CONAMA nº 273.

Em função desta percepção e do trabalho desenvolvido pelo corpo técnico da Cetesb, surgiu então, a Resolução do Conselho Nacional do Meio Ambiente - CONAMA - n 273, de 29/11/00, que exige dos postos revendedores, postos de abastecimento, instalações de sistemas retalhistas e postos flutuantes de combustíveis o licenciamento do órgão ambiental competente. Com a Resolução SMA n 5, de 28/03/01, que define como competência da Cetesb o licenciamento e a fiscalização dos estabelecimentos acima citados, o número de investigações aumentou bastante, sendo possível a identificação e a remediação de contaminações já existentes (informação verbal) ${ }^{1}$.

Na década de 70, houve um grande incentivo para comercialização de combustíveis e com isto houve um aumento considerável no número de postos do Brasil. Nesta época, os

\footnotetext{
${ }^{1}$ Informação fornecida pelo Assessor da Diretoria de Controle de Poluição da Cetesb, Dr. Elton Gloeden, em São Paulo, em 2006.
} 
tanques de combustíveis apresentavam um tempo de vida útil estimada de 25 anos. Assim sendo, é comum que atualmente, ocorram vários casos de vazamentos provocados por corrosão nestes tanques enterrados há aproximadamente, 30 anos (PENNER, 2000).

Quando ocorre um derramamento e/ou vazamento de gasolina, uma das principais preocupações é a contaminação dos aqüíferos que são usados como fonte de abastecimento de água para consumo humano (PENNER, 2000). Por apresentar pequena solubilidade em água, a gasolina derramada ficará no subsolo, em princípio, como líquido em fase não aquosa, ou seja, LNAPL, sendo uma fonte contínua de contaminação, além de apresentar risco de explosões e incêndios (FERREIRA, 2000). No entanto, quando em contato com a água subterrânea, a gasolina se dissolve parcialmente espalhando rapidamente a contaminação.

Enquanto não cessar a fonte de vazamento o solo vai tornando-se mais saturado de hidrocarbonetos e o centro de massa da pluma vai migrando descendentemente, deixando uma fase imóvel de contaminante no solo (MILLER, 2001).

A gasolina, entendida como contaminante, pode estar na subsuperfície em cinco fases: livre, residual, vapor, adsorvida e dissolvida (OLIVEIRA, BARKER e BANKS, 1998 e PENNER, 2000). A Figura 3 ilustra o comportamento da gasolina em um vazamento proveniente de armazenamento subterrâneo.

O contaminante migra em sentido vertical até encontrar a franja capilar de um aqüífero e aloja-se sobre ela, formando um reservatório que é chamado de fase livre. Já a fase residual diferencia-se da anterior por não possuir mobilidade, ou seja, ela é delineada como contaminante puro, porém que não consegue se mover por estar envolta por ar, água ou outro fluido. Embora também seja composta por líquido puro, trata-se de um aglomerado de gotas desconectadas e imóveis no meio poroso. Vale ressaltar que a fase residual pode, por vários motivos, tornar-se fase livre e vice-versa, tornando-se uma fonte de contaminação duradoura.

A fase vapor é caracterizada pela volatilização dos compostos orgânicos na zona nãosaturada do aqüífero. Estes vapores são oriundos, principalmente, da fase residual do aqüífero. 
Existe uma parte do contaminante que se adere à matéria orgânica presente no solo. Esta compõe a fase adsorvida. Das cinco fases acima citadas, a mais importante é a fase dissolvida, que corresponde ao produto dissolvido na água do aqüífero. Ela é a responsável pela dispersão do contaminante (PENNER, 2000). A transição do contaminante de uma fase para outra ou sua permanência em cada uma das fases é regida por propriedades físico-químicas já apresentadas anteriormente.

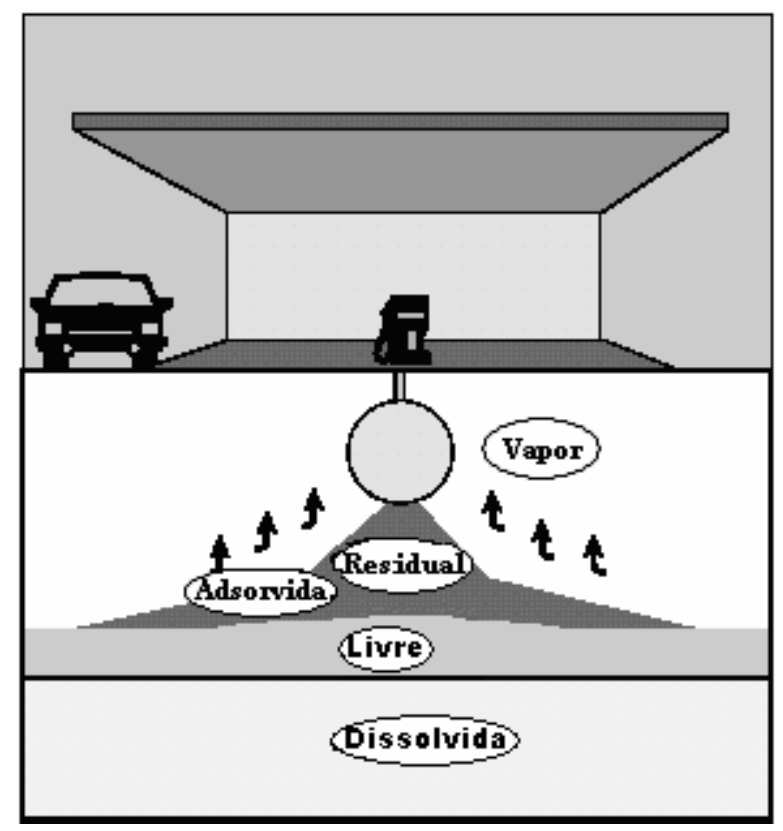

Figura 3 - Fases distintas de LNAPL após um vazamento em um aqüífero.

Fonte: Ferreira, 2004

Em um tanque de armazenamento subterrâneo que apresente vazamento de gasolina, a porcentagem de contaminante observada em fase livre (62\%) é a maior parte, no entanto, esta gasolina é responsável apenas por 1\% em volume do contaminado. Já, a gasolina dissolvida em água subterrânea, é pouco representativa (1-5\%) em comparação ao total derramado, porém, esta pequena fração, é responsável pela maior quantidade de material contaminado (79\%), uma vez que o contaminante, quando na água subterrânea, tem maior mobilidade. O produto que fica retido na fase adsorvida (33\%), embora de mobilidade muito baixa, dificulta a remediação da área atingida, pois funciona como uma fonte permanente de contaminação 
das águas subterrâneas pela liberação lenta e contínua de produto para a fase dissolvida (OLIVEIRA, 1992). A tabela 2 representa uma estimativa da distribuição por fases para a contaminação por gasolina, com 24\% de etanol, de um solo caracterizado como areia média, com lençol freático estando situado a uma profundidade de aproximadamente 5 metros.

Tabela 2 - Distribuição das fases do contaminante

\begin{tabular}{ccccc}
\hline Fase & $\begin{array}{c}\text { Volume } \\
\text { Contaminado } \\
\left(\mathbf{m}^{3} \mathbf{)}\right.\end{array}$ & $\begin{array}{c}\text { \% do } \\
\text { Total }\end{array}$ & $\begin{array}{c}\text { Volume de } \\
\text { Contaminante } \\
\mathbf{( m}^{3} \mathbf{)}\end{array}$ & $\begin{array}{c}\text { \% do } \\
\text { Total }\end{array}$ \\
\hline Livre & 7.100 & 1,0 & 18.500 & 62 \\
Adsorvida & 250.000 & 20,0 & 10.000 & 33 \\
Dissolvida & 960.000 & 79,0 & 333 & $1-5$ \\
\hline \multicolumn{2}{r}{} & & \multicolumn{2}{c}{ Fonte: Oliveira, 1992 }
\end{tabular}

\subsection{MECANISMOS DE TRANSPORTE OU MECANISMOS DE} TRANSFERÊNCIA DE MASSA - CONCEITOS BÁSICOS

O conhecimento da dispersão do combustível derramado no solo, bem como dos mecanismos de transporte que envolvem cada fase de desagregação, são importantes para que seja aplicada a melhor tecnologia de remediação.

O transporte horizontal da gasolina no aqüífero é realizado pelo movimento da água subterrânea. Ferreira (2000) afirma que os processos físicos responsáveis por este transporte são advecção e dispersão hidrodinâmica. O deslocamento vertical é função da condutividade hidráulica e anisotropia do meio. Segundo Oliveira (1997), as forças que agem na migração dos fluidos em subsuperfície ocorrem em função do tempo. Partindo deste princípio, há forças que influenciam no início, durante e no final do processo de migração.

Oliveira (1997) explica ainda que o processo de dispersão através do meio poroso ocorre através de dois mecanismos: advecção e difusão. A força motriz para a difusão é o gradiente de concentração enquanto para a advecção é o gradiente de pressão. 


\subsubsection{Advecção}

A advecção é o mecanismo de transporte mais importante no estudo da evolução de grande parte das plumas de contaminação (FERREIRA, 2000). Conforme Fetter (1993) este mecanismo é responsável pelo movimento do soluto junto à água subterrânea em fluxo.

Segundo Penner (2000) o fluido diminui a concentração do contaminante, uma vez que funciona como um dispersor, pois o poluente é transferido devido a um movimento preferencial do fluido.

Pode-se calcular a velocidade linear média no transporte advectivo através da Lei de Darcy:

$$
v_{x}=\frac{K}{\eta_{e}} \frac{\partial h}{\partial l}
$$

Onde:

$$
\begin{aligned}
& K=\text { condutividade hidráulica }(\mathrm{L} / \mathrm{T}) ; \\
& \eta_{e}=\text { porosidade efetiva; e } \\
& \frac{\partial h}{\partial l}=\text { gradiente hidráulico. }
\end{aligned}
$$

\subsubsection{Difusão}

Difusão é o processo através do qual íons e moléculas dissolvidas passam da área de maior concentração para a de menor concentração. Ela ocorre sempre que é formado um gradiente de concentração e, segundo Fetter (1993), a massa difundida é proporcional a este 
gradiente.

A difusão molecular pode ser aleatória (“Fickiniana”) ou restrita (“Kunudsen”) pelo contorno do meio, com espaços vazios limitando a superfície (MARKER, CUNHA E GÜNTHER, 1993). O fluxo de massa por unidade de área de seção transversal, depende do gradiente de concentração e é expresso como:

$$
F=D \frac{\partial C}{\partial x}
$$

Onde:

$$
\begin{aligned}
& F=\text { fluxo de massa; } \\
& D=\text { coeficiente de difusão; e } \\
& \frac{\partial C}{\partial x}=\text { gradiente de concentração. }
\end{aligned}
$$

\subsubsection{Condutividade hidráulica}

Segundo Hurtado (2004), é fundamental o conhecimento da condutividade hidráulica para qualquer estudo que envolva o movimento da água no solo. A condutividade hidráulica tem seu valor máximo no solo saturado e é dependente do teor de água ou de seu estado energético. Conforme diminui a umidade e a energia potencial matricial, o valor da condutividade hidráulica decresce.

Além de variar com a umidade, os resultados de determinação de condutividade hidráulica apresentados, tanto em pesquisas de laboratório como em campo, também têm grande variabilidade espacial (HURTADO, 2004).

Normalmente, a equação que descreve o fluxo de água no solo é a Lei de Darcy: 


$$
q=-K\left(\theta \psi_{m}\right) \operatorname{grad} H
$$

Onde:

$$
\begin{aligned}
& q=\text { densidade de fluxo; } \\
& K=\text { condutividade hidráulica; } \\
& \theta=\text { teor de água; } \\
& \psi_{m}=\text { estado energético; e } \\
& H=\text { potencial total de água no solo. }
\end{aligned}
$$

\subsubsection{Anisotropia do meio}

Segundo Winge (2001), o termo anisotropia significa “condição de variabilidade de propriedades físicas de um corpo rochoso ou mineral segundo direções diferentes, como, por exemplo, a variação da velocidade de propagação da luz (birrefringência) em minerais anisótropos; a variação de propagação de ondas sísmicas em massas rochosas estratificadas segundo diferentes direções.”

A anisotropia é uma característica muito freqüente nos elementos da natureza, isto é, a variabilidade ou distribuição espacial de tais elementos ocorre mais intensamente numa direção e menos intensamente em outra direção (CAMARGO; FELGUEIRAS e MONTEIRO, 2001). Por exemplo, no mapeamento do teor de contaminação por hidrocarbonetos dentro de uma determinada região é pouco provável que se observe que tal composto espalhou-se igualmente em todas as direções. 
Para trabalhar com a anisotropia, é importante que o modelo proposto represente bem a variabilidade espacial da propriedade em estudo. Modelos mais adequados para este objetivo vem sendo propostos e a geoestatística engloba estes modelos, cuja base conceitual está fundamentada na teoria das variáveis regionalizadas e nas funções aleatórias, conforme cita Camargo, Felgueiras e Monteiro (2001).

As diferenças existentes quanto à condutividade hidráulica e a ocorrência de anisotropia são determinantes quando se trata da direção e velocidade da migração da pluma de contaminação nos diversos tipos de solo. São estas diferenças alguns dos fatores que, somadas a dispersão e a difusão, condicionam o comportamento dos contaminantes no solo.

\subsection{FLUXO MULTIFÁSICO - CONCEITOS BÁSICOS}

Para facilitar o entendimento dos movimentos da gasolina em subsuperfície, Ferreira (2003) apresenta conceitos importantes com referência ao fluxo de líquidos imiscíveis com a água através das zonas não-saturada e saturada.

Segundo Miller (2001), existe uma relação entre a solubilidade e a mobilidade, ou seja, quanto mais solúvel um composto, maior a sua mobilidade. Já no caso da viscosidade, a sua redução aumenta a mobilidade. Esta relação reflete o poder de extensão da pluma de contaminação, principalmente no que diz respeito à gasolina acrescida de etanol, pois o etanol aumenta a solubilidade da gasolina e reduz a viscosidade desta. Embora a viscosidade sozinha não possa ser definida como parâmetro único para determinar a mobilidade, quando é levada em consideração a tensão interfacial ela é de grande valia na avaliação da contaminação.

Segue a apresentação de alguns conceitos básicos sobre o fluxo destes contaminantes. 


\subsubsection{Saturação}

Saturação do solo é definida como o volume de fluido armazenado nos poros, em relação ao volume total de poros existente em uma determinada porção de solo (FERREIRA, 2003). A saturação pode ser expressa pela equação:

$$
S=\frac{V_{f}}{V_{t}}
$$

Onde:

$$
\begin{aligned}
& S=\text { saturação; } \\
& V_{f}=\text { volume de fluido nos poros; e } \\
& V_{t}=\text { volume total de poros. }
\end{aligned}
$$

A soma de todas as saturações, em um sistema de multicomponentes, é igual a 1, conforme Ferreira (2003).

\subsubsection{Molhabilidade e tensão interfacial}

Segundo Ferreira (2003) e Oliveira (1997), molhabilidade é a tendência de um fluido, na presença de outros fluidos imiscíveis, "se espalhar ou aderir a uma superfície sólida" (FERREIRA, 2000). A molhabilidade influencia diretamente nos processos de deslocamento dos fluidos nos poros.

O que indica se um fluido é molhante ou não-molhante é o seu ângulo de contato. O 
ângulo de contato deve ser medido sempre no de maior densidade. Ângulo de contato menor que $90^{\circ}$ indica que o fluido é molhante, enquanto que o menor que $90^{\circ}$, não-molhante, como mostra a Figura 4. Já, ângulos de contato de "molhabilidade intermediária" são os próximos a $90^{\circ}$ (FERREIRA, 2003).

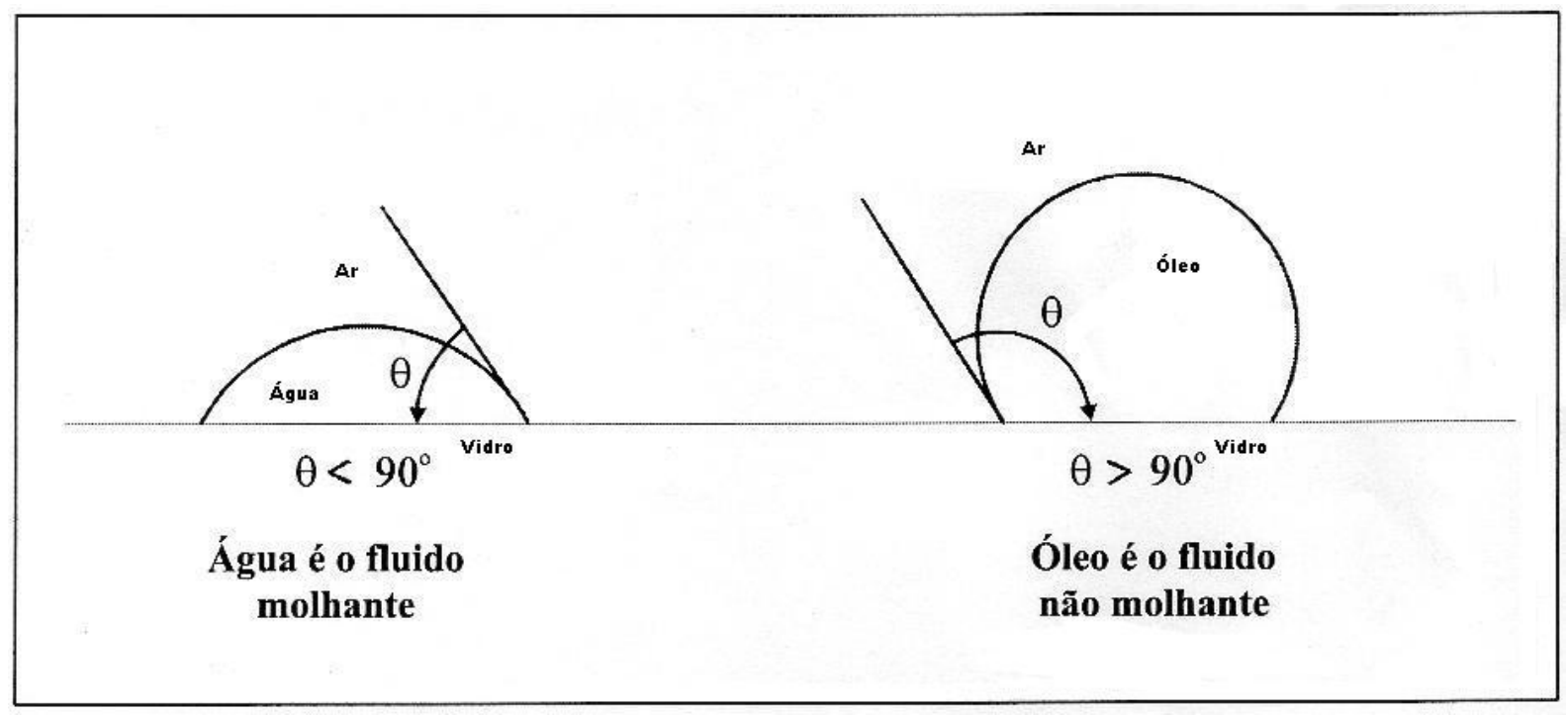

Figura 4 - Definição de molhabilidade com base no ângulo de contato Fonte: Ferreira, 2003

A tensão interfacial é uma força superficial por unidade de comprimento que atua no perímetro em direção tangente à superfície curva, conforme Dullien (1992). Tensão interfacial é a quantidade de trabalho que deve ser aplicado para separar em uma unidade de área os dois fluidos imiscíveis.

Os compostos oxigenados têm caráter co-solvente à medida que se dissolvem tanto em água (polar) quanto em gasolina (apolar), o que diminui a tensão interfacial entre a água e a gasolina no meio poroso, modificando volumes, densidades e a composição molar da gasolina e da água envolvidas na interação.

Bear (1972) afirma que a energia retida na interface de dois fluidos imiscíveis aumenta com a diferença da distância entre as moléculas sujeitas à atração (no interior de cada fluido) e as moléculas da área de contato entre as substâncias. Quando a superfície que contém a 
energia é contraída, a energia manifesta-se em forma de tensão interfacial.

Quando ocorre a redução da tensão interfacial, parte da massa do combustível (que contém etanol e compostos BTEX) é transferida para a água. Desta forma, o grupo formado aumenta sua solubilidade devido à presença do etanol.

Segundo Oliveira (1997) o etanol presente na gasolina, permite que ela particione-se para a água do meio poroso. Este efeito co-solvente, facilita a entrada do contaminante em poros muito pequenos, nos quais a gasolina pura não poderia entrar. Isto ocorre devido à redução da tensão interfacial entre a água e a gasolina.

Com o fluxo simultâneo da água com a gasolina, a fase molhante (neste caso a água) envolve a fase não-molhante (gasolina), que passa a ocupar a fase central do capilar. Assim, a água obriga a gasolina a sair do capilar avançando lateralmente.

\subsubsection{Pressão Capilar}

Segundo Ferreira (2003), quando ocorre o encontro de dois fluidos imiscíveis em um tubo de diâmetro reduzido, forma-se um menisco no encontro deles e as pressões dos poros próximas à interface de cada um deles também é diferente. Pressão capilar é justamente esta diferença de pressão através da interface dos fluidos. A equação 3.7 define a pressão capilar.

$$
P_{c}=P_{n w}-P w
$$

Onde:

$$
\begin{aligned}
& P_{c}=\text { pressão capilar; } \\
& P_{n w}=\text { pressão do fluido não-molhante; e } \\
& P_{w}=\text { pressão do fluido molhante. }
\end{aligned}
$$


A Figura 5 ilustra o conceito de pressão capilar em um capilar com água, onde o valor da $P_{c}$ é dado pela Equação 3.8:

$$
P_{c}=P_{o}-P_{w}=2 \frac{\sigma_{o w} \cos \theta}{r}
$$

Onde:

$$
\begin{aligned}
& P_{o}=\text { pressão do óleo; } \\
& P_{w}=\text { pressão da água; } \\
& \sigma_{o w}=\text { tensão interfacial óleo-água; } \\
& \theta=\text { ângulo de contato; e } \\
& r=\text { raio do tubo. }
\end{aligned}
$$

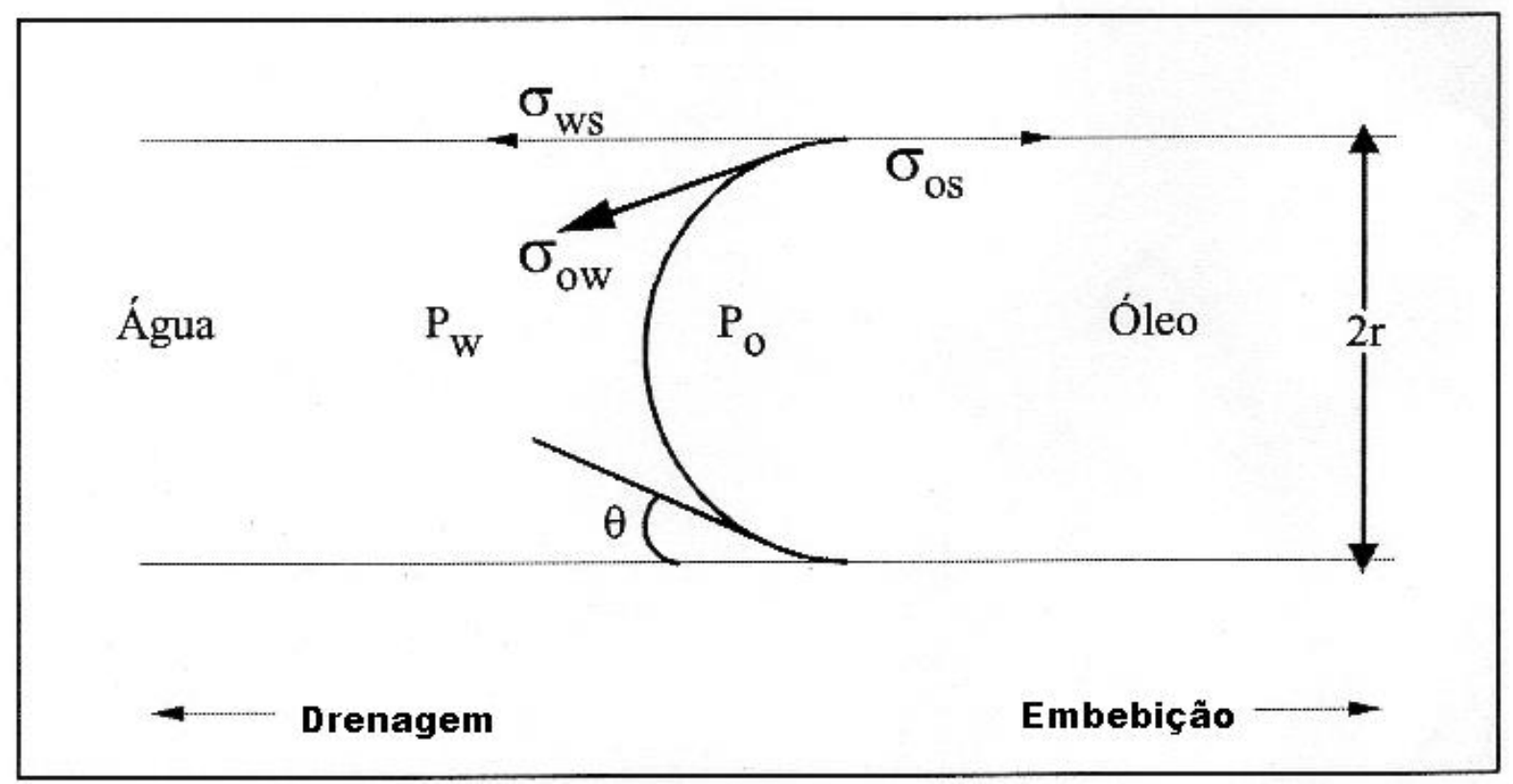

Figura 5 - Conceito de pressão capilar em um capilar ( $\sigma_{w s}=$ tensão interfacial água-sólido e $\sigma_{o s}=$ tensão interfacial óleo-sólido) Fonte: Ferreira, 2003

Quando tubos de vidros de diferentes diâmetros são colocados em um recipiente com água, o tubo com menor diâmetro é o que apresenta a maior altura de coluna (Figura 6). Isto 
ocorre, devido à interação do material da parede do tubo de vidro com as moléculas de água, expõe Ferreira (2003). Esta situação é explicada pela pressão capilar.

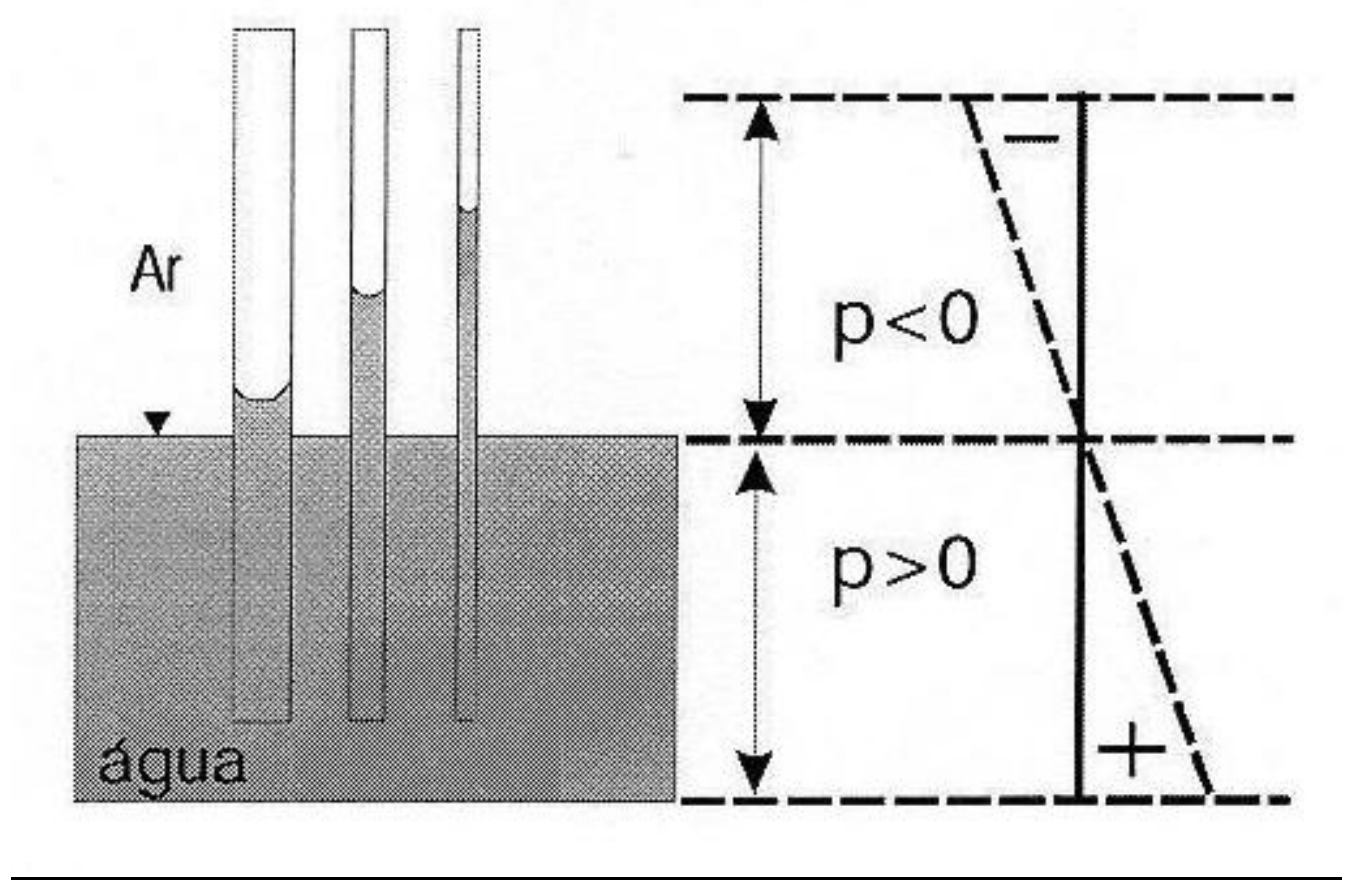

Figura 6 - Ascensão da água em tubos capilares de diâmetros diferentes

$$
\text { ( } p \text { = pressão) }
$$

Fonte: Ferreira, 2003

Conforme afirmação de Ferreira (2003), a água está presa no tubo sob tensão pois o nível de água no recipiente e o ar ao redor estão sob pressão atmosférica. A altura da elevação da água $\left(\mathrm{h}_{\mathrm{c}}\right.$ ) no tubo capilar é igual a pressão dividida pelo peso específico da água, como mostra a Equação 3.9. Assim, a pressão capilar e a altura da elevação capilar são proporcionais à tensão interfacial e inversamente proporcionais ao raio da garganta dos poros.

$$
h_{c}=\frac{2 \sigma \cos \theta}{\gamma \cdot r}
$$

Onde:

$$
h_{c}=\text { altura da ascensão capilar; }
$$




$$
\begin{aligned}
& \sigma=\text { tensão interfacial (dinas/cm); } \\
& \theta=\text { ângulo de contato (graus); } \\
& \gamma=\text { peso específico da água (dinas } / \mathrm{cm}^{3} \text { ); e } \\
& r=\text { raio da garganta dos poros. }
\end{aligned}
$$

Segundo Kochina (1952), é possível estimar a altura de ascensão capilar em um meio poroso, em função do diâmetro efetivo dos grãos e da porosidade, como mostra a Equação 3.10:

$$
h_{c}=\frac{0,45(1-\eta)}{d_{10} \cdot \eta}
$$

Onde:

$$
\begin{aligned}
& h c=\text { altura da ascensão capilar }(\mathrm{cm}) ; \\
& \eta=\text { porosidade efetiva; e } \\
& d_{10}=\text { diâmetro efetivo dos grãos }(\mathrm{cm}) .
\end{aligned}
$$

A Figura 7 mostra um exemplo de como o solo pode se comportar. Normalmente, o solo é formado por poros de diversos diâmetros, como ilustra a figura citada na qual cada tubo de vidro possui diâmetro diferente dos outros. O fluido no exemplo é água, assim como o material de construção do tubo é vidro. Portanto, temos no exemplo o encontro de dois fluidos - água e ar - em contato com a parede de vidro. Desta forma, pode-se notar as diferentes elevações capilares conforme o diâmetro do tubo, ou seja, diferentes pontos de saturação, de acordo com os diferentes tamanhos de gargantas de poros. 


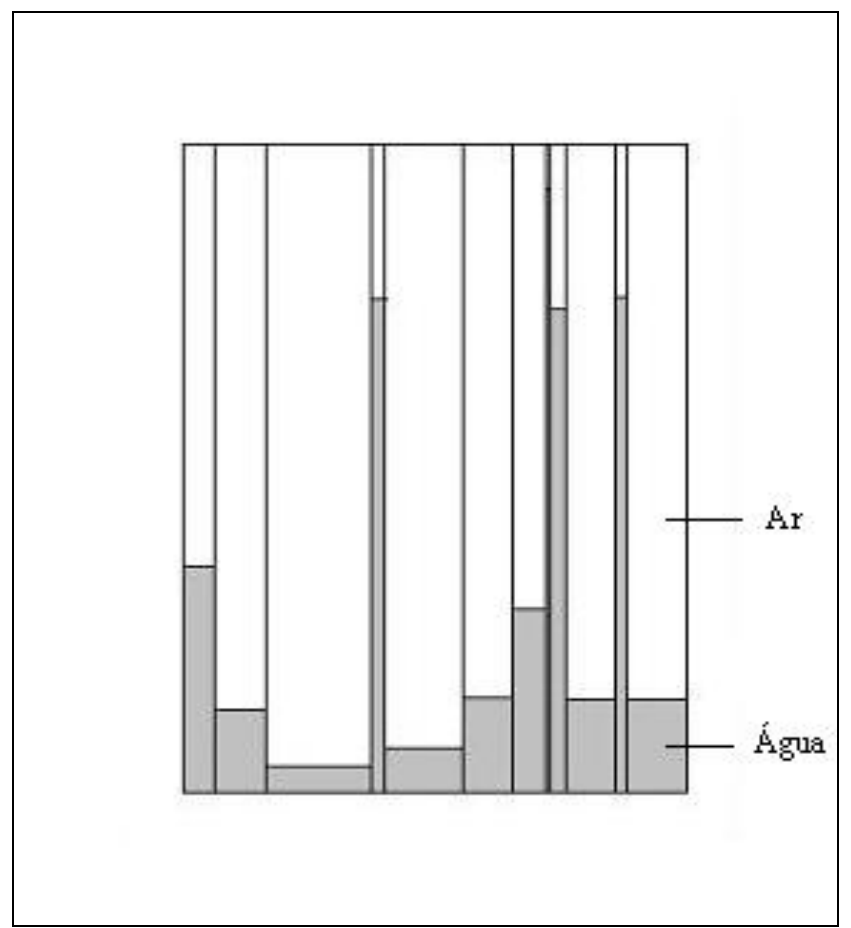

Figura 7 - Esquema mostrando a elevação capilar para diferentes gargantas de poros Fonte: adaptado de Ferreira, 2003

A Tabela 3 mostra as variações nas alturas das franjas capilares observadas experimentalmente em vários materiais, no exemplo, a porosidade das amostras é de aproximadamente 41\% . A altura capilar visível é o nível onde a saturação da água é próxima a 1.

Tabela 3 - Altura capilar visível em materiais não consolidados

\begin{tabular}{ccc}
\hline Material & Tamanho do Grão (mm) & Altura Capilar (mm) \\
\hline Cascalho fino & $2-5$ & 0,25 \\
Areia muito grossa & $1-2$ & 0,65 \\
Areia grossa & $0,5-1$ & 1,35 \\
Areia média & $0,2-0,5$ & 2,46 \\
Areia fina & $0,1-0,2$ & 4,28 \\
Areia muito fina & $0,05-0,1$ & 10,55 \\
Silte & $0,02-0,05$ & $>20,0$ \\
\hline \multicolumn{2}{c}{ Fonte: Lohmon, 1972, apud Fetter, 1993}
\end{tabular}




\subsubsection{Drenagem e embebição}

Segundo Fetter (1993) a gasolina, em trajetória descendente, rompe a força capilar que retém a água e acumula-se, tornando esta zona saturada de combustível em fase livre e não mais de água. No entanto, a água e o ar, em sua saída, podem ficar retidos no meio poroso, conforme mostra Figura 8, representada por água e óleo em um micromodelo de vidro. Este fenômeno geralmente é chamado na literatura por um anglicismo: “trapeamento”. Este termo designa uma redução do espaço ocupado pela gasolina, o que faz com que a gasolina ocupe outros poros espalhando-se lateralmente.

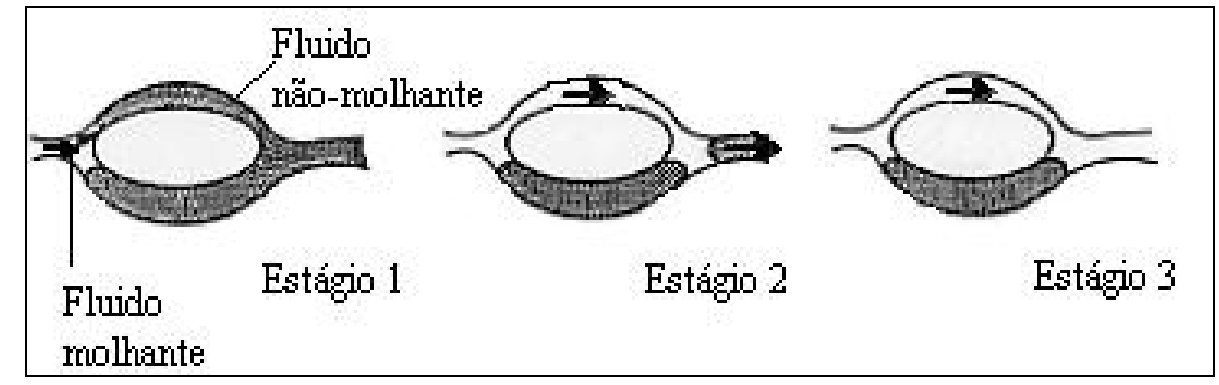

Figura 8 - “Trapeamento” de água

Fonte: Adaptado de Chatzis e Dullien, 1983

“Embebição” é o termo usado para descrever o fluido molhante aumentando a saturação sobre o não-molhante (como na Figura 8). Para tanto, é necessário que $\mathrm{P}_{\mathrm{nw}} \leq \mathrm{P}_{\mathrm{w}}+\mathrm{P}_{\mathrm{c}}$. Assim, o fluido molhante desloca o não-molhante. Ao contrário de “embebição”, o termo “drenagem” é utilizado para descrever o fluido não-molhante deslocando o molhante e para isto é necessário $\mathrm{P}_{\mathrm{nw}} \geq \mathrm{P}_{\mathrm{w}}+\mathrm{P}_{\mathrm{c}}$. Em um capilar contendo o encontro de água e óleo, para que a água seja deslocada pelo óleo, a pressão do óleo deve ser tal que $\mathrm{P}_{\mathrm{o}} \geq \mathrm{P}_{\mathrm{w}}+\mathrm{P}_{\mathrm{c}}$ (FERREIRA, 2003).

Como visto anteriormente: 


$$
\begin{aligned}
& P_{c}=\text { pressão capilar; } \\
& P_{n w}=\text { pressão do fluido não-molhante; e } \\
& P_{w}=\text { pressão do fluido molhante. }
\end{aligned}
$$

3.6 REGIÃO METROPOLITANA DE SÃO PAULO E O MUNICÍPIO DE GUARULHOS

Segundo dados da Cetesb (maio de 2006) - Tabela 4, das 1664 áreas contaminadas identificadas no Estado de São Paulo, 35\% encontram-se nas cidades do interior, 21,3\% nos municípios da Região Metropolitana de São Paulo, 30\% no Município de São Paulo e 13,7\% no Litoral e Vale do Paraíba. O que mostra que juntos, somente a capital e a RMSP, somam mais de $51 \%$ das áreas identificadas. Outro fator de relevância é que os tanques de armazenamento subterrâneos de combustíveis foram responsáveis por 73\% desses acidentes e a gasolina foi o produto com maior vazamento.

Tabela 4 - Áreas contaminadas no Estado de São Paulo - Novembro 2005

\begin{tabular}{ccccccc}
\hline $\begin{array}{c}\text { Região/ } \\
\text { Atividade }\end{array}$ & Comercial & Industrial & Resíduos & $\begin{array}{c}\text { Postos de } \\
\text { combustível }\end{array}$ & $\begin{array}{c}\text { Acidentes } \\
\text { desconhecidos }\end{array}$ & Total \\
\hline $\begin{array}{c}\text { São Paulo } \\
\text { RMSP }-\end{array}$ & 27 & 45 & 20 & 406 & 2 & 500 \\
$\begin{array}{c}\text { outros } \\
\text { Interior }\end{array}$ & 14 & 73 & 11 & 253 & 4 & 355 \\
Litoral & 10 & 32 & 11 & 70 & 12 & 581 \\
$\begin{array}{c}\text { Vale do } \\
\text { Paraíba }\end{array}$ & 1 & 20 & 0 & 83 & 1 & 124 \\
Total & 100 & 259 & 65 & 1221 & 19 & 1664 \\
\hline
\end{tabular}


Para a distribuição das áreas contaminadas foram consideradas as seguintes regiões:

São Paulo: Capital do Estado;

RMSP - outros: 38 municípios da Região Metropolitana de São Paulo, excluindose a Capital;

Litoral: municípios do Litoral Sul, Baixada Santista, Litoral Norte e Vale do Ribeira;

Vale do Paraíba: municípios do Vale Paraíba e da Mantiqueira e

Interior: municípios não relacionados anteriormente.

A população do estado de São Paulo é de 40,3 milhões de habitantes, conforme o endereço eletrônico do Governo do Estado de São Paulo (2006), enquanto que a população da RMSP é 17,8 milhões habitantes. Assim, a população da RMSP representa 48,2 \% do Estado, enquanto que em área, representa 3,2\%. O que permite concluir que um número muito grande de pessoas convive com este problema cotidianamente.

A Figura 9 mostra a distribuição de áreas contaminadas identificadas por atividade no Estado de São Paulo com base nos dados de maio de 2006 fornecidos pela Cetesb. Através do gráfico, pode-se destacar a grande quantidade de áreas contaminadas por postos de gasolina, diante das demais atividades.

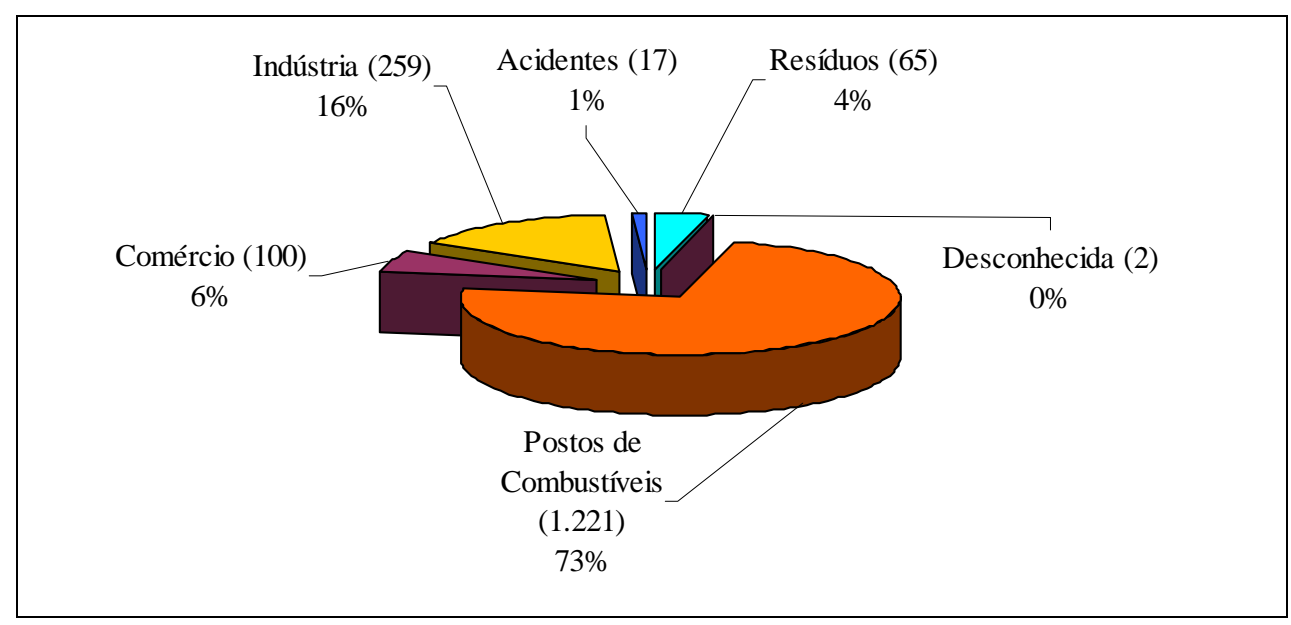

Figura 9 - Distribuição de áreas contaminadas por atividade

Fonte: Cetesb, maio de 2006 
A cidade de Guarulhos, com uma área legal de 341 km² e altitude de 759 m, localizase a nordeste da Região Metropolitana de São Paulo, sendo um dos 39 municípios que a integra. Está inserida em uma malha rodoviária bastante importante: Rodovia Presidente Dutra (São Paulo - Rio de Janeiro), Rodovia Fernão Dias Paes Leme (São Paulo - Belo Horizonte) e Rodovia Ayrton Senna (acesso ao Vale do Paraíba). Apresenta-se posicionada estrategicamente no principal eixo de desenvolvimento do País: São Paulo / Rio de Janeiro / Minas Gerais e faz divisa com a capital do estado, conforme pode-se notar na Figura 10.

Na Tabela 5, pode-se observar os municípios que compõem a RMSP individualmente, com a dimensão de suas áreas e sua população. Nesta tabela é possível visualizar a densidade demográfica de cada cidade, destacando o número de habitantes que pode estar exposto às contaminações por hidrocarbonetos provenientes de postos de combustíveis, destacando que em Guarulhos ainda existe uma grande área desabitada. 


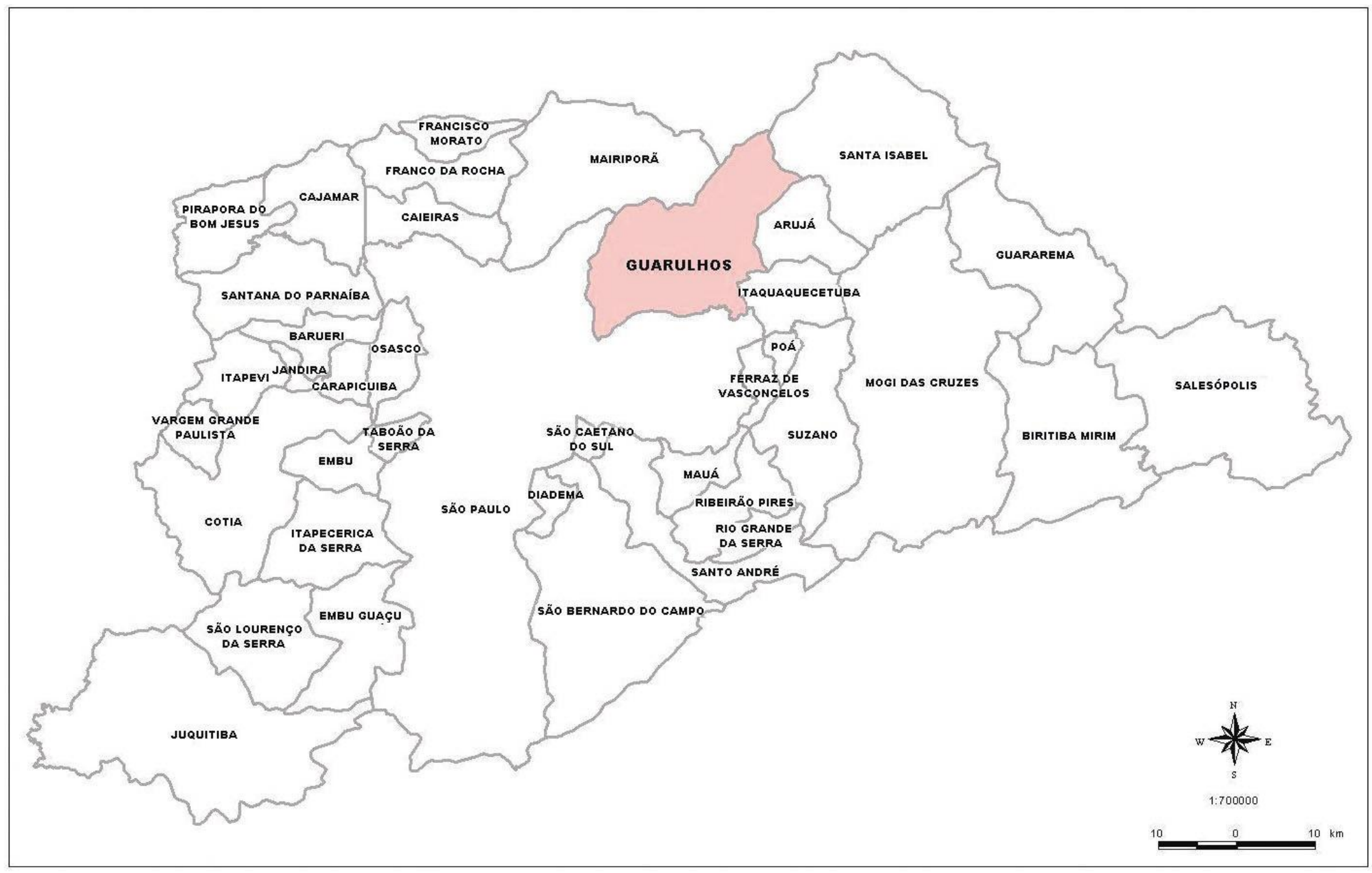

Figura 10 - Mapa da Região Metropolitana de São Paulo 
Tabela 5 - Municípios da Região Metropolitana de São Paulo

\begin{tabular}{|c|c|c|c|}
\hline Município & Área $\left(\mathbf{k m}^{2}\right)$ & População (hab) & Densidade demográfica (hab/km²) \\
\hline Arujá & 96 & 59.080 & 615,42 \\
\hline Barueri & 61 & 208.028 & 3410,30 \\
\hline Biritiba Mirim & 44 & 24.567 & 558,34 \\
\hline Caieiras & 104 & 70.849 & 681,24 \\
\hline Cajamar & 135 & 50.244 & 372,18 \\
\hline Carapicuíba & 36 & 343.668 & 9546,33 \\
\hline Cotia & 325 & 148.082 & 455,64 \\
\hline Diadema & 32 & 356.389 & 11137,16 \\
\hline Embu & 68 & 206.781 & 3040,90 \\
\hline Embu-Guaçu & 171 & 56.709 & 331,63 \\
\hline Ferraz de Vasconcelos & 25 & 141.939 & 5677,56 \\
\hline Francisco Morato & 45 & 133.248 & 2961,07 \\
\hline Franco da Rocha & 143 & 107.997 & 755,22 \\
\hline Guararema & 262 & 21.880 & 83,51 \\
\hline GUARULHOS & 341 & 1.071.299 & 3141,64 \\
\hline Itapecerica da Serra & 136 & 129.156 & 949,68 \\
\hline Itapevi & 79 & 162.421 & 2055,96 \\
\hline Itaquaquecetuba & 83 & 272.416 & 3282,12 \\
\hline Jandira & 22 & 91.721 & 4169,14 \\
\hline Juquitiba & 550 & 26.479 & 48,14 \\
\hline Mairiporã & 307 & 59.708 & 194,49 \\
\hline Mauá & 67 & 363.112 & 5419,58 \\
\hline Mogi das Cruzes & 731 & 329.680 & 451,00 \\
\hline Osasco & 68 & 650.993 & 9573,43 \\
\hline Pirapora do Bom Jesus & 99 & 12.338 & 124,63 \\
\hline Poá & 17 & 95.724 & 5630,82 \\
\hline Ribeirão Pires & 107 & 104.336 & 975,10 \\
\hline Rio Grande da Serra & 31 & 36.352 & 1172,65 \\
\hline Salesópolis & 418 & 14.330 & 34,28 \\
\hline Santa Isabel & 361 & 43.473 & 120,42 \\
\hline Santana de Parnaíba & 176 & 74.722 & 424,56 \\
\hline Santo André & 181 & 648.443 & 3582,56 \\
\hline São Bernardo do Campo & 411 & 700.405 & 1704,15 \\
\hline São Caetano do Sul & 12 & 140.144 & 11678,67 \\
\hline São Lourenço da Serra & 192 & 12.185 & 63,46 \\
\hline São Paulo & 1.509 & 10.406.166 & 6896,07 \\
\hline Suzano & 185 & 228.439 & 1234,81 \\
\hline
\end{tabular}




\begin{tabular}{lccc}
\hline \multicolumn{1}{c}{ Município } & Área (km²) & População (hab) & Densidade demográfica (hab/(km²) \\
\hline Taboão da Serra & 20 & 197.460 & 9873,00 \\
Vargem Grande Paulista & 38 & 32.548 & 856,53 \\
Total na RMSP & 7688 & 17.833 .511 & 2319,66
\end{tabular}

A população de Guarulhos supera um milhão de habitantes (segundo endereço eletrônico da Prefeitura Municipal de Guarulhos, 2006), sendo, portanto, a segunda cidade mais populosa do estado, superada apenas pela capital. Por sua condição geográfica e climática, Guarulhos apresentava uma cobertura vegetal primitiva nativa representada pela Mata Atlântica, também denominada Floresta Cantareira e pela Mata Planaltina ou de Transição, que, com a expansão populacional e industrial sofreu grande desgaste, estando reduzida a algumas pequenas áreas preservadas.

Atualmente, a cidade tem como áreas verdes o Parque Estadual Cantareira (Núcleo Cabuçu) com 2.550 ha., a fazenda de Itaverava, algumas áreas localizadas na Tapera Grande, Horto Florestal de Guarulhos - que tem uma parte classificada como Reserva Biológica, além de pequenos redutos de mata existentes na cidade: Bosque Maia, Parque Fracalanza, Aeroporto Internacional, entre outros, resultantes do trabalho de paisagismo, que utiliza tanto espécies nativas quanto espécies exóticas e encontram-se preservados pela Legislação de Proteção Permanente.

Além de abrigar o Aeroporto Internacional de São Paulo, com capacidade para atender 17 milhões de passageiros por ano, o município é um importante pólo industrial do Estado, ocupando o sétimo lugar no tocante à produção industrial. Seu parque industrial é o mais diversificado do estado.

Existe uma grande explotação de águas subterrâneas na cidade. Só o Aeroporto Internacional de São Paulo, em Cumbica, por exemplo, utiliza oito poços, que operam 12 h/dia, fornecendo 2.700 m³/dia de água. Há a previsão de duplicar este volume. Existem 
muitos bairros em que as famílias utilizam-se somente de poços para abastecimento próprio, o que agrava o risco, uma vez que em todos os postos pesquisados que apresentam contaminações, estas já alcançaram as águas subterrâneas.

Cartograficamente, a área de interesse, encontra-se sobre terrenos sedimentares de idade Cenozóica, compreendendo os depósitos Terciários da Bacia de São Paulo e as coberturas aluviais mais recentes, de idade Quaternária, encontradas ao longo dos principais rios da região. Os terrenos cristalinos contornam as áreas sedimentares e configuram, praticamente, toda a borda da RMSP (COUTINHO, 1980). Sob o contexto hidrogeológico, os sedimentos da Bacia de São Paulo assentados sobre o substrato cristalino constituem dois grandes sistemas aqüíferos distintos: o Sistema Aqüífero Cristalino e o Sistema Aqüífero São Paulo (COUTINHO, 1980).

Segundo este autor, o sistema aqüífero da RMSP é composto por rochas sedimentares da Bacia de São Paulo, que está localizada no Planalto Paulistano e apresenta relevo suavizado de morros e espigões relativamente baixos, com suas drenagens fluindo para os Rios Tietê, Pinheiros e Tamanduateí e seus tributários.

Regionalmente o aqüífero possui espessura média de 100 m e máxima de 290 m e ao longo dos depósitos aluviais aflora muito próximo à superfície. O nível base local deste aqüífero é o Rio Tietê e a descarga das águas é em direção a ele.

Coutinho (1980) explica ainda que o Sistema Aqüífero Cristalino caracteriza-se por duas zonas distintas de sistema de fluxo da água subterrânea: a rocha alterada onde a água percola, principalmente nos interstícios resultantes do intemperismo e a rocha sã ou pouco alterada, onde a água flui preferencialmente pelas fissuras e fraturas.

As formações São Paulo e Itaquaquecetuba, pertencentes ao Sistema Aqüífero São Paulo não podem ser separadas em aqüíferos distintos devido à ausência de estudos neste sentido. 


\subsection{CONTAMINAÇÕES EM GUARULHOS}

No banco de dados do Cadastro de Áreas Contaminadas, divulgado pela Cetesb e atualizado em novembro/2005, consta que na cidade de Guarulhos foram identificadas 46 áreas contaminadas, sendo que 78\% dos empreendimentos são postos de combustíveis. Do restante, ainda que não sejam postos, apenas 4 locações não apresentam combustíveis líquidos como principal contaminante.

O processo de recuperação de áreas contaminadas adota o princípio de “aptidão para o uso” e é constituído por seis etapas: investigação detalhada, avaliação de risco, investigação para remediação, projeto de remediação, remediação e monitoramento.

Das contaminações geradas por postos de combustíveis, quase todas possuem como fonte de contaminação o armazenamento. Somente um deles tem como fonte de contaminação um derramamento que ocorreu durante o abastecimento de um dos tanques. Destas contaminações, apenas seis já possuem proposta de remediação, o que representa 17\%, enquanto que $61 \%$ não apresentaram ainda sua proposta. No entanto, 31\% já estão com remediação em andamento. Dos empreendimentos que possuem áreas contaminadas e ainda não apresentaram proposta de remediação, somente um deles está na fase de investigação detalhada, os demais ainda encontram-se na etapa de investigação confirmatória.

As investigações realizadas nestas áreas contaminadas, principalmente por combustíveis líquidos, mostram que $17 \%$ atingiram áreas fora da propriedade do empreendimento responsável pelo vazamento. Como meio impactado, percebe-se que $81 \%$ dos vazamentos já alcançaram o subsolo e destes, $40 \%$ estão também no solo superficial. No entanto, o maior agravante é que apenas dois vazamentos não atingiram as águas subterrâneas, porém, ambos encontram-se na etapa de investigação confirmatória, o que leva a crer que há 
possibilidade de também estarem contaminadas as águas subterrâneas.

Como principais contaminantes, pode-se destacar, além dos combustíveis líquidos presentes em 100\% das áreas, que 8,3\% apresentam hidrocarbonetos policíclicos aromáticos (PAH), 16,7\% solventes aromáticos e 41,7\% apresentam os três contaminantes.

As ações emergenciais efetivamente realizadas pelos proprietários dos empreendimentos são apresentadas no gráfico da Figura 11, que ilustra a situação atual, mas em 11 casos, ainda não registrou-se nenhuma ação.

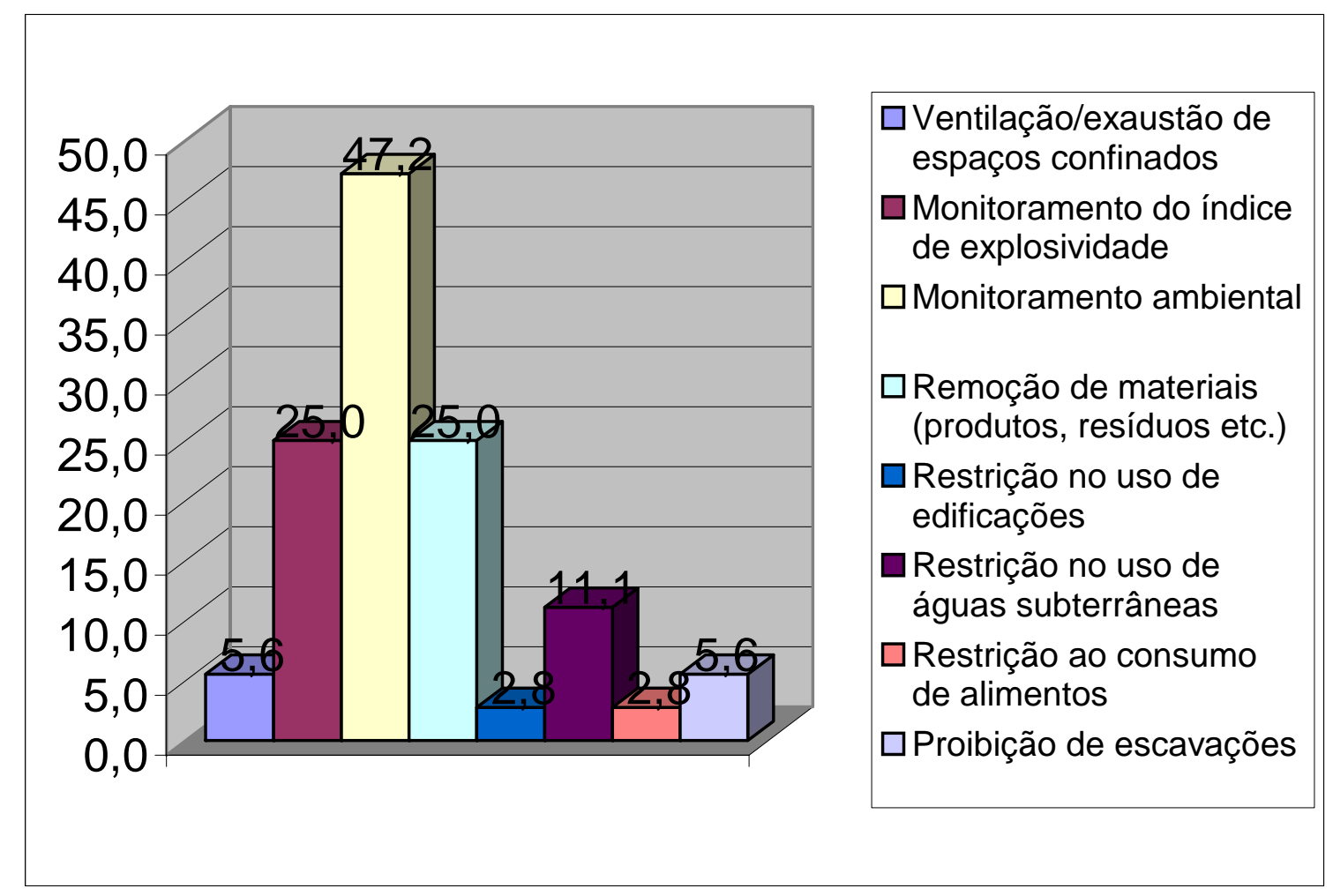

Figura 11 - Ações emergenciais e de controle institucional

Já com relação aos processos de remediação, como visto anteriormente, 61,1\% ainda não possuem remediação em andamento. Dos outros 38,9\% que já estão sendo remediados de alguma forma, três estão utilizando bombeamento e tratamento, dois extração de vapores do solo (SVE), outros três optaram pela remoção de solo/resíduo e cinco deles estão recuperando 
a fase livre. O gráfico da Figura 12 apresenta a situação atual dos processos de remediação atualmente utilizados.

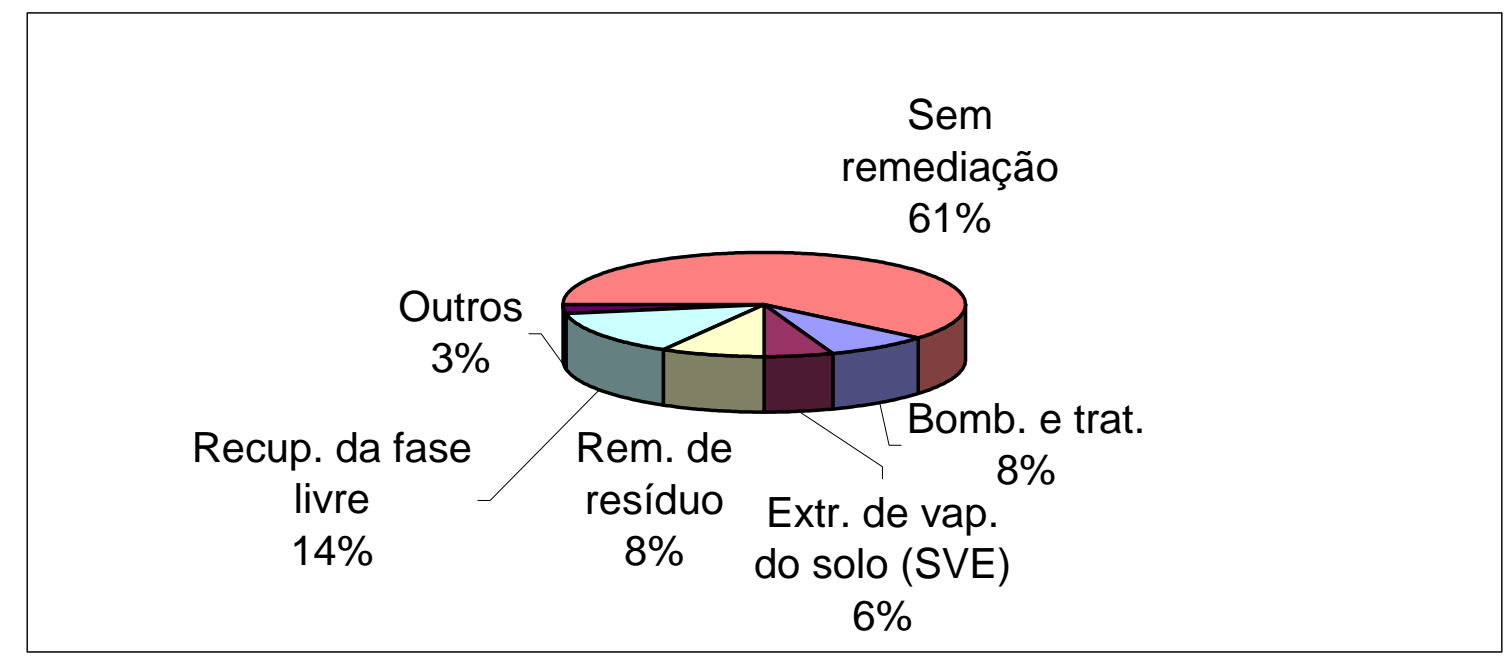

Figura 12 - Processos de remediação utilizados

\subsection{METODOLOGIAS QUE PRECEDEM A REMEDIAÇÃO}

Muitas vezes, quando é percebido um vazamento, este já se encontra bastante avançado, tornando-se difícil a quantificação de contaminante. Muitos autores apresentaram trabalhos no sentido de quantificar o volume vazado retido por capilaridade na zona saturada e não-saturada. Lenhard e Parker (1990), Busby et al. (1995), Farr et al. (1990), Ferreira (2003) entre outros, utilizaram as curvas de saturação do solo. Já Huntley et al. (1994), relaciona as diferentes espessuras encontradas nos poços de monitoramento às granulometrias heterogêneas existentes no solo ao redor.

Os mecanismos de transferências de massa do contaminante de uma fase para a outra ocorrem de forma dinâmica. A quantidade de produto presente em cada fase pode alterar-se 
tanto devido à biodegradabilidade como por transferência de massa da fase livre, para fase vapor, ou da fase vapor para adsorvida, ou de fase livre para dissolvida e assim por diante. Esta situação induz a erros significativos associados à quantificação de combustível presente na subsuperfície (LAGREGA, 1994; FERREIRA, 2000).

Através do mapeamento da pluma de contaminação em fase livre e adsorvida, é possível estimar-se a concentração do contaminante no solo e no vapor deste, desde que seja conhecida a massa inicial de contaminantes que, neste momento, distribui-se nas diversas fases (FERREIRA, 2003). Segundo a EPA (1991), a fase vapor pode espalhar os contaminantes numa área maior do aqüífero numa velocidade até 10.000 vezes maior do que através do movimento da água subterrânea.

Segundo Pereira (2000), Bucci (2000) e Miller (2001), as alterações na granulometria, teor de umidade e heterogeneidade do solo, causam variações na retenção capilar. Estas variações são responsáveis pelas diferenças de espessura encontradas quando se associa a fase livre existente no poço de monitoramento à fase livre que existe sobre o nível d’água. Nos locais com efeitos capilares maiores, como argilas e siltes, esta diferença exagerada é mais notada.

O Manual de Gerenciamento de Áreas Contaminadas, Lopes et al. (2001) explica as diferenças entre remediação ou recuperação ${ }^{2}$ de uma determinada área contaminada e divide as medidas de remediação em dois tipos:

a) medidas de contenção ou isolamento da contaminação e

b) medidas para o tratamento dos meios contaminados visando a eliminação ou redução dos níveis de contaminação a níveis aceitáveis ou previamente definidos.

Assim, neste estudo, considera-se recuperação como sendo remediação (contenção e

\footnotetext{
${ }^{2}$ Recuperação significa readquirir uma condição, enquanto que remediação significa dar remédio, sanear, tornar uma área saudável (LOPES et al., 2001).
} 
tratamento) e compatibilização ao uso atual ou futuro da área.

Para o estudo de passivo ambiental, os poços de monitoramento são muito importantes, uma vez que é através deles que são feitas as investigações para delimitação da pluma de contaminação. As análises químicas de solo e água, informações sobre litologia e potenciometria local, anisotropia do terreno, partem destes poços.

O volume de combustível presente na contaminação, muitas vezes também é estimado através das análises realizadas nestes poços de monitoramento. Alguns autores - Oliveira (1997), Pereira (2000), Ferreira (2003), entre outros - realizaram estudos com o intuito de encontrar técnicas para que, através da altura de fase livre seja possível mensurar o volume de combustível contido no solo. A informação incorreta quanto à quantidade de combustível pode levar a uma escolha errada de técnica de remediação, o que implicaria em um custo super ou subestimado.

Segundo a EPA (1991) a implantação dos poços de monitoramento, através dos quais é realizado o mapeamento da pluma de fase livre, é um processo de tentativa e erro. A abertura de um poço em um determinado local é baseada nos resultados das análises do poço que o precedeu. Para a investigação de LNAPLs, na construção dos poços de monitoramento, deve-se cuidar para que os filtros estendam-se desde acima da franja capilar até abaixo do nível d’água.

Segundo Miller (2001), algumas técnicas de remediação utilizam água do próprio aqüífero para promover a expulsão do combustível da zona não saturada, no entanto, esta situação pode causar um enclausuramento do líquido não-molhante, o que causaria um agravamento no quadro da contaminação ao invés de uma remediação. Os combustíveis presentes no solo devido à contaminação, apresentam uma certa geometria. Esta geometria quando é quebrada devido à infiltração de água, faz com que o contaminante desça, chegando mais rapidamente em contato com a água subterrânea modificando e aumentando o quadro de 
contaminação local.

Neste cenário, encontram-se inúmeras tecnologias que podem ser utilizadas para remediação destas áreas contaminadas com hidrocarbonetos. Até 28 de outubro de 2003, o Banco de Dados de Tecnologia de Remediação e Caracterização da Agência de Proteção Ambiental dos Estados Unidos da América (EPA REACH IT - US Environmental Protection Agency Remediation and Characterization Technology Database) relacionou 1.294 tecnologias de remediação (STIER, 2004). Devido, principalmente a esta variedade de tratamentos encontrados atualmente, é necessário que o tratamento seja cuidadosamente escolhido, uma vez que se pode incorrer no erro de escolher-se uma tecnologia inovadora mas que não atenda ao tipo de remediação necessária para o caso em si.

Conforme Stier (2004), para que uma tecnologia de remediação seja escolhida com acerto, deve-se considerar a geologia, hidrogeologia, hidrogeoquímica, características físicas e químicas dos contaminantes, aspectos regionais (custos de energia, preço de mão-de-obra) e aspectos políticos. Lopes et al. (2001) acrescenta ainda o tempo e recursos disponíveis.

A Figura 13 mostra um fluxograma de decisão quanto à tecnologia de remediação a ser escolhida. Nele, estão incluídos os principais envolvidos na questão: os proprietários, os consultores e as autoridades. 


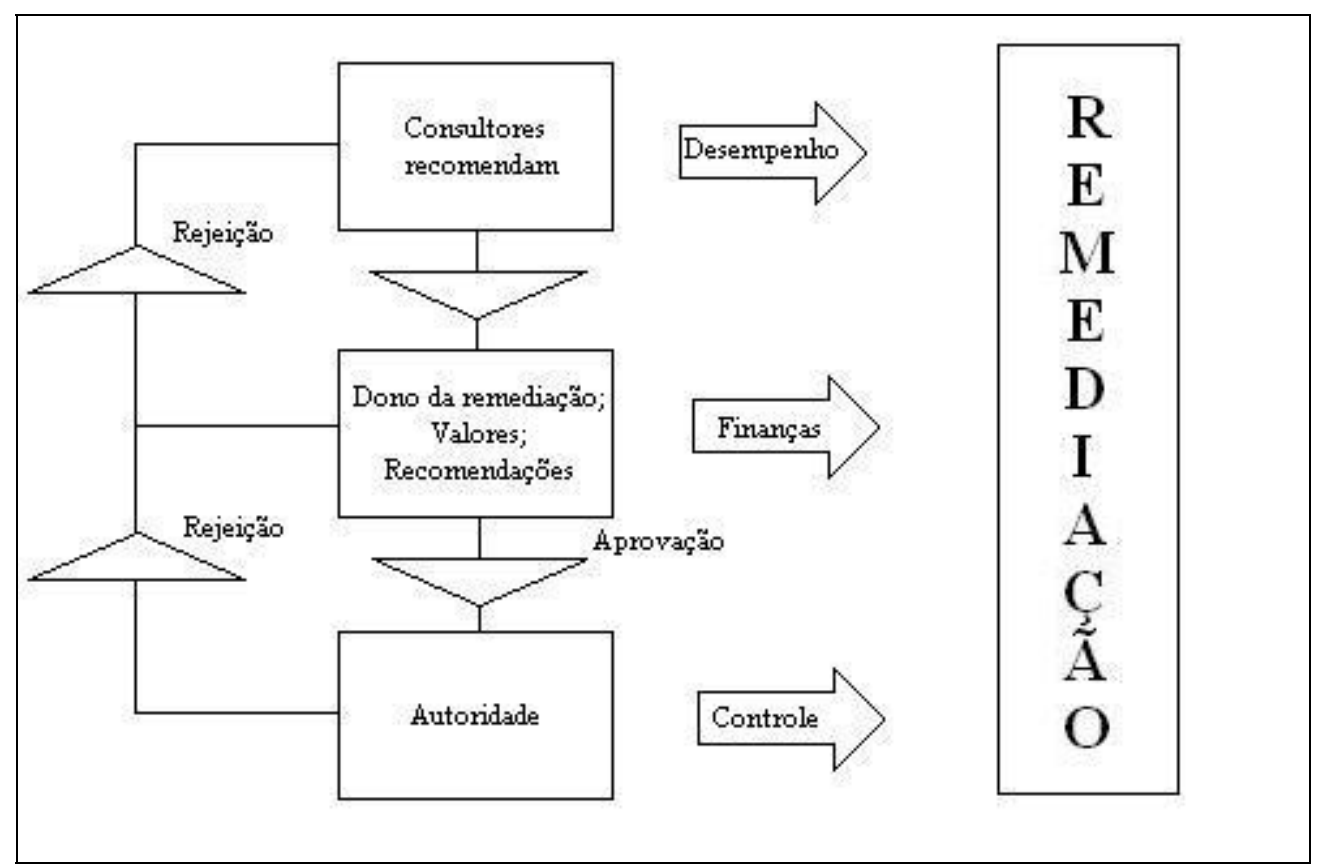

Figura 13 - Fluxograma de decisão quanto à tecnologia de remediação a ser escolhida Fonte: adaptado de Stier, 2004

Normalmente, a decisão é tomada pelo proprietário da área contaminada. Como nem sempre o proprietário tem experiência ou conhecimento sobre o assunto, esta decisão deve estar baseada na recomendação de um consultor e supervisionada pela autoridade competente. (STIER, 2004).

Este autor afirma que normalmente, o processo de remediação tende a responder a um questionamento:
a) a área contaminada justifica a pesquisa?
b) a área contaminada requer uma ação de remediação?
c) qual ação de remediação é necessária?
d) a ação de remediação, uma vez concluída, atingiu sua meta?

Para amparar as decisões nas necessidades das ações de remediação, utiliza-se a análise de risco. Segundo o autor supra citado, ela deve ser utilizada em todas as fases de 
remediação, pois, quando aplicada holisticamente, a análise de risco subsidia as decisões do gerenciamento do risco tornando mais eficiente o uso dos recursos para proteger a saúde pública e o meio ambiente, como apresentado a seguir.

\subsubsection{Análise de risco}

Segundo a USEPA (1989) o processo de análise de risco, em linhas gerais, possui quatro etapas definidas: coleta e avaliação de dados, análise de exposição, análise de toxidade e caracterização do risco. A análise de risco mostra-se mais eficaz quando é aplicada como um modelo de tomada de decisão para o processo de remediação de uma área contaminada como um todo (SONG, 2004).

A análise de risco é de extrema importância para o reconhecimento do cenário no qual está inserida determinada área contaminada. Quando utilizada de forma apropriada, através dela, pode-se avaliar com eficiência as opções de reutilização da área contaminada.

Segundo Song (2004), a análise de risco serve para:

promover a discussão sobre as incertezas versus certezas das condições de uma contaminação;

aumentar o reconhecimento das incertezas e das escolhas para saná-las;

apresentar fundamentos lógicos para facilitar a comunicação dos "atores" envolvidos;

orientar a pesquisa fornecendo uma base para o planejamento de coleta de dados; e

garantir que as razões para a conclusão da remediação são compatíveis com as que foram tomadas para iniciá-la. 
A análise de risco é definida por este autor como:

$$
\text { Risco }=\text { Exposição X Perigo }
$$

Em uma análise de risco, a análise da exposição e a análise do perigo são avaliadas separadamente. A avaliação da exposição trata do cenário da exposição e a dose calculada. A avaliação dos vários cenários de exposição que fazem referência tanto às condições presentes quanto futuras, é um dos objetivos da análise de risco (SONG, 2004).

Assim, para garantir que a análise de risco irá se desenvolver de forma adequada no auxílio do gerenciamento deste, é importante que a localização de cenários de exposição se inicie antes do processo de remediação. Para cada cenário de exposição que permite uma análise quantitativa é desenvolvida uma estimativa de dose, a partir das hipóteses relativas à magnitude, freqüência e duração da exposição. A equação geral de dose é a seguinte:

$$
\text { Dose }=\frac{C \cdot I R \cdot F C \cdot A F \cdot E F \cdot E D}{B W \cdot A T}
$$

Onde:

$C=$ concentração média à qual a população receptora pode ser exposta num período especificado;

$I R=$ taxa de assimilação de um meio no ambiente (e.g., quantidade de água consumida por dia);

$F C=$ fração de assimilação que está contaminada pela área;

$A F=$ fração de contaminantes no meio que é absorvida pelo organismo;

$E F=$ freqüência de exposição; 


$$
\begin{aligned}
& E D=\text { duração da exposição; } \\
& B W=\text { peso corpóreo; e } \\
& A T=\text { período no qual a exposição é calculada. }
\end{aligned}
$$

A avaliação do perigo consiste na identificação do perigo, que é uma determinação qualitativa dos tipos de efeitos à saúde que uma substância química pode causar e análise de dose referência, que avalia a relação quantitativa entre a dose e a severidade de um efeito à saúde em particular.

Para a caracterização do risco, conforme Song (2004) pode ser exemplificado com a caracterização dos riscos cancerígenos e não-cancerígenos. Estes riscos associados a exposições orais e dermatológicas para uma substância química são estimados pela combinação de doses estimadas com os valores de toxicidade das substâncias químicas seguindo a equação:

$$
\begin{gathered}
\text { Risco }=\text { LADD.SF } \\
H Q=\frac{A D D}{A T}
\end{gathered}
$$

Onde:

$L A D D=$ dose diária média para expectativa de vida $(70$ anos por convenção);

$S F=$ fator de ingestão oral;

$H Q$ = quociente de perigo não-cancerígeno;

$A D D=$ dose diária média; $\mathrm{e}$

$A T$ = período no qual a exposição é calculada. 
Já os riscos de câncer por inalação e não-cancerígenos são estimados de maneira similar:

$$
\begin{aligned}
\text { Risco } & =C \cdot U R F \cdot \frac{E F \cdot E D}{A T} \\
H Q & =\frac{C}{R f C} \times \frac{E F \cdot E D}{A T}
\end{aligned}
$$

Onde:

$C=$ concentração média à qual a população receptora pode ser exposta em um período especificado;

$\mathrm{URF}$ = fator de risco por unidade de inalação;

$E F$ = freqüência de exposição;

$E D$ = duração da exposição;

$A T$ = período no qual a exposição é calculada;

$H Q$ = quociente de perigo não-cancerígeno; e

$R f C$ = concentração de referência de inalação.

Ainda, segundo Song (2004), os riscos associados à exposição de misturas de substâncias químicas numa área são geralmente analisados assumindo a aditividade dos riscos, como segue:

$$
\begin{aligned}
& \text { RiscoCumulativo }=\sum_{i} \text { Risco }_{i} \\
& H I=\sum_{i} H Q_{i}
\end{aligned}
$$


Onde:

HI = índice de perigo; e

$H Q$ = quociente de perigo não-cancerígeno.

O índice de perigo pode ser calculado em separado para cada grupo de substâncias químicas que simula o mesmo instrumento alvo ou tem o mesmo modo de ação. Conforme EPA (1991), a aditividade é a hipótese padrão, pois é reconhecido que o conhecimento científico corrente, via de regra, é bastante limitado para abranger as misturas.

Song (2004) afirma que mesmo para áreas contaminadas em que a remediação é, sem dúvida, necessária, a análise de risco também é necessária, uma vez que, a partir desta análise é possível distinguir qual a melhor remediação a ser utilizada no local. Embora as análises de risco possam conduzir a escolhas de remediação mais custosas, a utilização de cenários de exposição muito conservadores mostra que estas escolhas são necessárias.

As alternativas de remediação, além de diversas, alteram-se de acordo com o cenário apresentado (CUNHA, 1997). Para exemplificar como a análise de risco pode auxiliar na escolha da remediação mais adequada, Song (2004) mostra uma situação em que uma área contaminada esteja expondo seus trabalhadores a uma contaminação por um determinado produto que possua risco de câncer inaceitável para a saúde destes. Assim, os cálculos do risco de câncer cumulativo devem ocorrer de forma a identificar qual é a substância química. Remove-se então, a concentração mais alta desta substância química dos cálculos de concentração de exposição e o risco cumulativo é recalculado. Repete-se então este procedimento até que este risco estimado seja aceitável.

A idéia principal de Song (2004), é usar a estrutura da análise de risco para estimar os riscos pós-remediação. Em alguns casos, esta avaliação é conduzida em conjunto com monitoramento periódico do desempenho da remediação, em monitoramento periódico das 
plumas de contaminantes, dentre outras.

\subsubsection{Ações Corretivas com Base no Risco - ACBR}

O Risk Based Corrective Action - RBCA é um procedimento eficiente de tomada de decisões baseadas em risco, desenvolvido pela American Society for Testing and Materials (ASTM). Tendo como modelo a norma ASTM 204-01 Guide for Risk Based Corrective Action at Chemical Release Sites (RBCA), a Cetesb (2004) elaborou uma metodologia, a ACBR Ações Corretivas com Base no Risco, direcionada, especificamente, a áreas com problemas de contaminação por hidrocarbonetos derivados de petróleo (HDP).

A análise de risco visa estabelecer as concentrações limites nos pontos de exposição identificados, as taxas de ingresso, os riscos associados, bem como as concentrações limites para os compostos de interesse na área em estudo, a fim de assegurar que os receptores identificados não estejam expostos a riscos crônicos à saúde humana, conforme os critérios de riscos adotados (CETESB, 2004).

O ACBR caracteriza-se pela utilização dos dados de análise de risco, análise de exposição e modelos de transporte de massa em meio saturado e não saturado.

Para avaliação efetuada pelo ACBR, é fundamental a elaboração de cenários de exposição. Estes cenários devem representar a evolução do contaminante partindo da origem da contaminação até chegar aos receptores potenciais, passando pelos diferentes caminhos de exposição (CETESB, 2004).

No procedimento ACBR, o processo de análise de risco baseia-se numa classificação inicial da área quanto à necessidade de ações imediatas seguida por três estágios de coleta, 
tratamento e interpretação dos dados: Nível 1, Nível 2 e Nível 3 - ou no RBCA Tier 1, Tier 2 e Tier 3. Estes estágios tornam-se progressivamente mais específicos e complexos à medida que o estudo sobre a área e o contaminante é desenvolvido.

Previamente à interpretação dos dados, a metodologia ACBR Nível 2 estabelece que se deva classificar a área quanto à urgência da necessidade de ações de resposta inicial, baseando-se em informações coletadas durante as etapas de investigação. Esta classificação tem como finalidade orientar a implementação ou não de ações emergenciais destinadas a minimizar os riscos agudos, bem como de ações que proporcionem a contenção da expansão da contaminação (espalhamento) de eventuais hidrocarbonetos presentes em fase livre, dissolvida ou na forma de vapor (CETESB, 2004).

No Nível 1 de avaliação, os valores de concentração dos compostos químicos de interesse, obtidos no ponto de exposição, devem ser comparados com os valores aceitáveis de concentração, chamados Níveis de Avaliação Baseados no Risco (NABR), como apresentados para o Estado de São Paulo no Sub-Anexo 01 da metodologia ACBR (CETESB, 2004) Anexo A. Os NABR são resumidos em tabelas, denominadas Tabelas de Referência, que relacionam os cenários de exposição às concentrações de referência para cada composto considerado - Anexo I.

Neste nível, o principal objetivo é gerar uma base de informações para que sejam tomadas decisões relativas ao processo de gerenciamento ambiental. A partir destes dados pode-se decidir se é necessário uma análise mais aprofundada do caso ou se já é necessária a implementação de ações corretivas.

O ACBR permite que, no caso de metas impraticáveis de remediação, ou a existência de limitações tecnológicas ou ainda, de recursos financeiros, parta-se para um nível de maior detalhamento de informações, “considerando a coleta de informações adicionais da área para o estabelecimento de Concentração Meta Baseada no Risco (CMEA) nos NÍVEIS 2 e 3.” 
(CETESB, 2004). Nestes níveis, compara-se os valores observados na área-fonte, nos pontos de exposição e nos pontos de conformidade com as Concentrações Meta Específicas da Área.

Segundo ACBR, nos NÍVEIS 2 e 3 podem ser utilizados modelos matemáticos de transporte, de atenuação natural e de biodegradação de contaminantes para que sejam calculadas as concentrações dos possíveis contaminantes nos pontos de exposição e nos pontos de conformidade.

A classificação da urgência da área é baseada na norma ASTM E1739-95 (2000) Standard Guide for Risk-Based Corrective Action (RBCA) Applied at Petroleum Release Sites, desenvolvida pela ASTM, em conjunto com exemplos de classificação de cenários e potenciais respostas iniciais. Essa classificação é baseada no grau de perigo atual e futuro para a saúde humana, segurança e para o meio ambiente.

Área “Classe 1” são associadas com riscos imediatos à saúde humana, à segurança e ao meio ambiente; Áreas “Classe 2” são associadas com riscos de curto prazo (0 - 2 anos); áreas “Classe 3” são associadas com riscos de longo prazo (maiores que 2 anos) e Áreas “Classe 4” não estão associadas a qualquer risco potencial razoável à saúde humana, à segurança e ao meio ambiente.

A partir desta classificação, é que se deve executar um plano de remediação. Como já citado anteriormente, existem inúmeras tecnologias de remediação, da mesma forma, são bastante variadas as formas de classificação para estas tecnologias, conforme descrito a seguir. 


\subsection{TECNOLOGIAS DE REMEDIAÇÃO COMUMENTE UTILIZADAS}

\subsubsection{Bombeamento e tratamento (Pump \& Treat)}

Os sistemas de contenção hidráulica convencionais - Pump \& Treat - são ainda utilizados na maioria dos sítios contaminados, conforme afirma Nobre, M. M. e Nobre, R. C. M. (2003). Apesar da necessidade de remover grandes volumes de água do subsolo, de forma a extrair os contaminantes, essa metodologia pode ser uma medida eficiente de remediação, em certas condições, devido às lentas taxas de desorção e dissolução dos compostos.

Segundo Schenk (2004), o bombeamento de águas subterrâneas contaminadas ocorre para tratamento e posterior reinjeção no solo. Normalmente o tratamento é feito com caixa separadora de água e óleo ou com carvão ativado e remoção de gases (air strippers). Contudo, os compostos BTEX, são moderadamente hidrofóbicos, com isso ficam adsorvidos pelos materiais do aqüífero, conforme já mostrado anteriormente, sendo uma constante fonte de contaminação. Este motivo, torna difícil a remoção completa destes compostos por bombeamento. Este fator, torna a tecnologia de Pump \& Treat proibitiva para remoção de contaminação residual e inviável economicamente, quando utilizada isoladamente.

A utilização de Pump \& Treat com carvão ativado, não são considerados destrutivos, transferindo a contaminação de uma fase para a outra, não tornando inócuo o contaminante (STIER, 2004).

O insucesso de sistemas Pump \& Treat, cita Nobre, M. M. e Nobre, R. C. M. (2003), normalmente resulta de uma caracterização preliminar insuficiente ou inadequada do problema. No entanto, sistemas de bombeamento de águas subterrâneas bem executados 
podem controlar a migração da pluma para regiões mais afastadas, permitindo a remoção de fontes secundárias da contaminação, além de ser uma necessidade indiscutível antes da implementação da maioria das tecnologias de remediação, em sítios que apresentam fase livre de contaminante.

\subsubsection{Remoção de gases (Air Strippers)}

Segundo Negrão (2002), a tecnologia de air strippers ou air stripping consiste na extração de água subterrânea contaminada, para aumentar a área de contato dos compostos orgânicos voláteis com o ar, o que resulta no particionamento dos compostos voláteis presentes na água contaminada. A remoção por aeração permite a transferência de contaminantes orgânicos da fase líquida para a fase gasosa (SILVA, 2004). Stripping é a técnica de extração do contaminante orgânico do solo ou da água por aplicação de vácuo ou ar (FERREIRA, 2000).

Silva (2004) explica que se trata de uma tecnologia não destrutiva, o que significa que, no processo de Air Strippers, a corrente de água contaminada é misturada com uma corrente de ar descontaminado e, este contato, faz com que o ar remova as substâncias orgânicas dissolvidas na água. Os métodos de aeração incluem packed towers, aeração por difusão, aeração por bandejas e por jateamento.

Esta tecnologia é muito utilizada para tratamento de águas subterrâneas contaminadas com compostos orgânicos com constantes maiores que 0,01 atmosferas $\mathrm{m}^{3} / \mathrm{mol}$. BTEX, Cloroetano, TCE, DCE e PCE são exemplos de contaminantes retirados com sucesso através desta tecnologia. Nos projetos de remediação de águas subterrâneas, este processo costuma 
ser realizado de duas formas diferentes: através de colunas de stripping ou de tanques de aeração.

Negrão (2002), descreve os equipamentos de air stripper, da seguinte maneira: o modelo padrão de air stripper de coluna é composto por um jato de água contaminada no topo da coluna, que é distribuída sobre o material de enchimento (packer). Há um ventilador que força um fluxo de ar no sentido contrário ao escoamento da água. A água descontaminada fica armazenada num tanque na base da coluna. Podem ser adicionados ao air stripper padrão, alguns equipamentos auxiliares, tais como: aquecedores de ar para aumentar a eficiência da remoção de gases; sensores de nível no tanque de armazenamento de água para automatização do sistema; de dispositivos de segurança, tais como medidores diferenciais de pressão; sensores de nível crítico para o tanque d’água; componentes a prova de explosão; controladores de emissão de gases e sistemas de tratamento de gases, tais como unidade de carvão granulado ativado, oxidadores catalíticos ou catalisadores térmicos. 


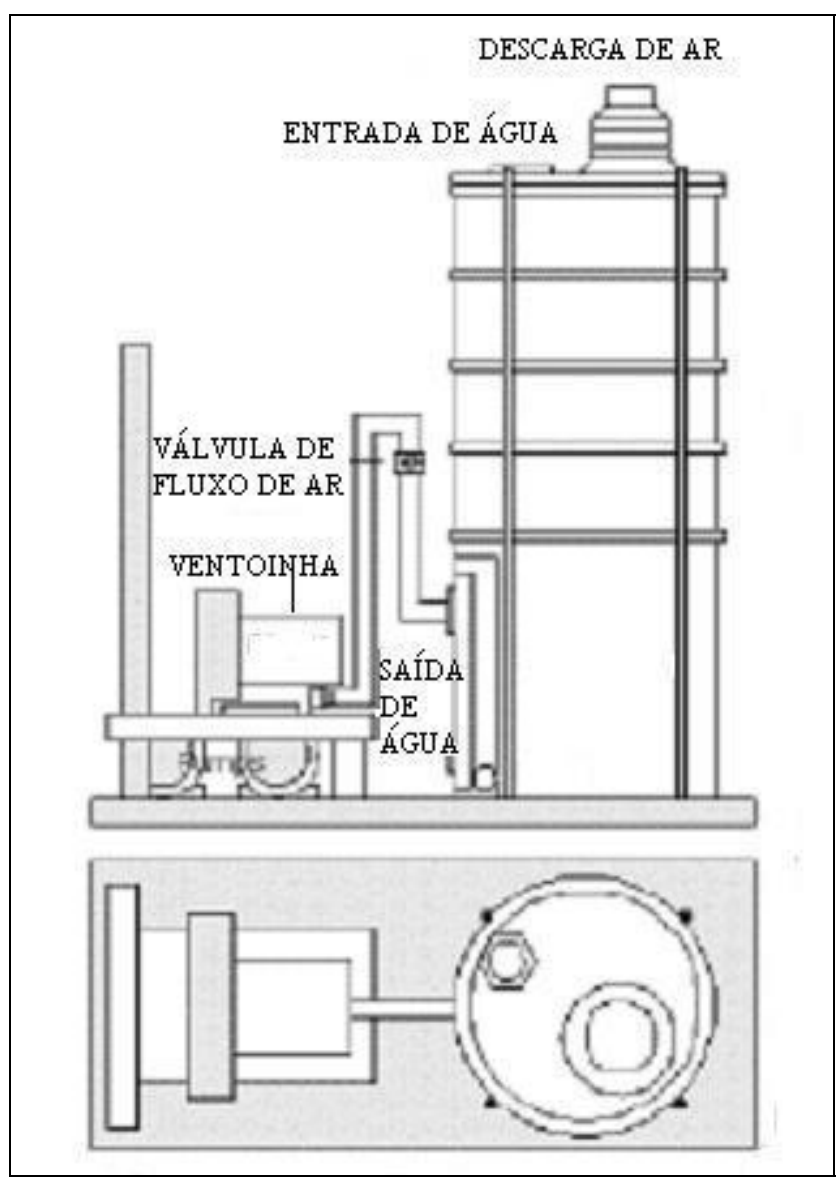

Figura 14 - Esquematização de um Air Stripper de coluna

Fonte: Negrão, 2002

Já os tanques de aeração retiram os compostos voláteis através da introdução de bolhas de ar no tanque aonde a água contaminada é armazenada (NEGRÃO, 2002). Um sistema de ventiladores e manifolds de distribuição das bolhas de ar são projetados para garantir um ótimo contato água-ar, de maneira que não seja necessário nenhum material de preenchimento (packers). As chicanas e as unidades múltiplas garantem um tempo de residência adequado para que o fracionamento ocorra. Os tanques de aeração são tipicamente oferecidos em unidades de operação contínua. Uma das vantagens do tanque de aeração é a altura reduzida da unidade (menos de 2m de altura) em comparação com os strippers de torre (5 a 12 m de altura). 
A habilidade de poder modificar as configurações dos sistemas de air strippers aumenta significantemente a eficiência de remoção dos gases. Negrão (2002) afirma que umas das mais recentes inovações são os chamados Low Profile Air Strippers (tamanho reduzido). Essas unidades acomodam várias bandejas numa única câmara de tamanho reduzido, de maneira a maximizar a área de contado ar-água, além de reduzir o espaço ocupado pelo stripper. Devido ao seu tamanho reduzido, estas unidades têm sido utilizadas amplamente em projetos de remediação de águas subterrâneas (NEGRÃO, 2002).

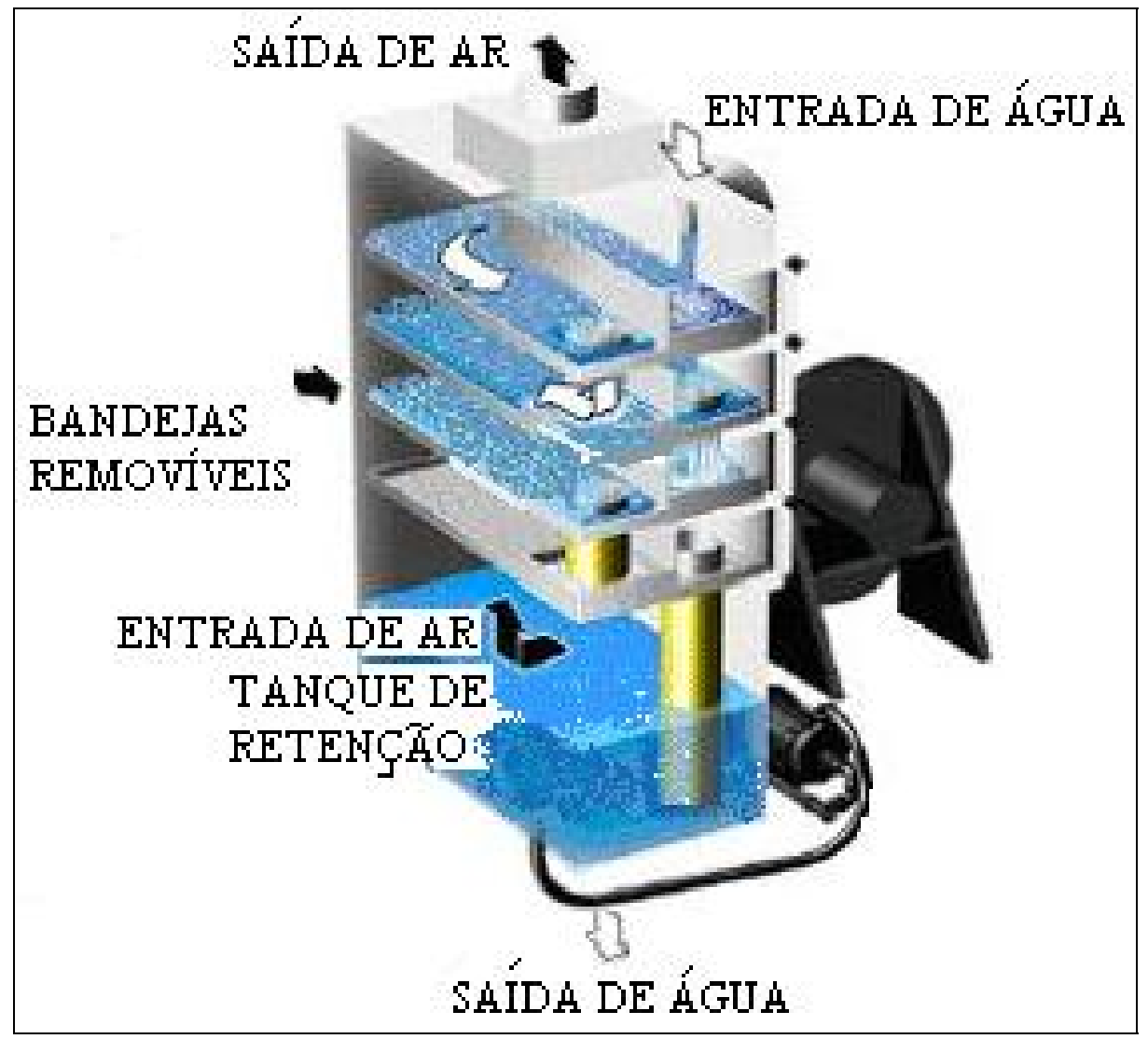

Figura 15 - Esquematização de um Low Profile Air Strippers

Fonte: Negrão, 2002

Negrão (2002), define também alguns fatores limitantes na utilização da tecnologia de air strippers: 
> existência de compostos orgânicos no solo (ex: ferro acima de 5ppm, dureza acima de 800ppm) ou incrustações de matérias biológicas no equipamento, exigindo prétratamento ou limpeza periódica do sistema;

$>$ eficiente somente para água contaminada por compostos orgânicos voláteis (COV) ou semivoláteis (SCOV) com constantes de Henry maiores que 0,01;

$>$ deve se considerar a quantidade e tipo de material de preenchimento (packer) que deve ser usado na torre;

os custos com energia para operar o sistema são tipicamente elevados;

compostos de baixa volatilidade a temperatura ambiente podem exigir préaquecimento da água subterrânea; e

a emissão de gases pode exigir tratamento dependendo das taxas de emissão.

Por ser uma tecnologia não destrutiva ele apresenta como desvantagens, segundo Silva (2004), a geração de resíduos que necessitam disposição adequada. O gás removido requer tratamento, os tempos de retenção são bastante baixos, conseqüentemente grandes quantidades de emissões e concentrações de efluentes podem ser processadas. Os padrões de água para consumo humano podem apresentar dificuldades em serem atingidos e as altas concentrações de efluentes podem gerar concentrações perigosas na corrente de ar.

No entanto, ainda observa Silva (2004) como vantagens: o fato de ser uma tecnologia de comprovada confiabilidade; o tempo de montagem do equipamento é relativamente pequeno; a manutenção requer pouca especialização; o processo apresenta-se insensível a flutuações de concentrações do efluente; é aplicável à ampla variação de concentrações no efluente; despoluição de efluentes com alto índice de toxicidade, como no caso dos organohalogenados, agrotóxicos, antibióticos e orgânicos não biodegradáveis. 


\subsubsection{Carvão ativado}

Normalmente o carvão ativado é utilizado em conjunto com outras técnicas, principalmente para extração de compostos orgânicos voláteis, conhecidos como COV’s, através da adsorção (MARTINS, 2004).

Segundo este autor o carvão ativado é derivado de uma variedade de materiais compostos de carbono, incluindo coque de petróleo, madeira, carvão, turfa, caroço de frutas, casca de nozes. É comumente produzido através da utilização de vapor superaquecido - entre 800 a $1.000{ }^{\circ} \mathrm{C}$ - que complementa o processo de alargamento dos poros em toda superfície interna. A distribuição do tamanho dos poros, a área superficial e a composição química da superfície afetam fortemente a capacidade, seletividade, cinética, custo e características do carvão ativado. A faixa de áreas de superfície no carvão ativado varia de 300 a 1500 m²/g, embora carvão de coque de petróleo possa exceder $3.000 \mathrm{~m}^{2} / \mathrm{g}$. Carvão ativado é fornecido comercialmente na forma de partículas ou pó com diâmetro de 2 a 4 mm. O carvão ativado atrai moléculas apolares, como hidrocarbonetos, pelas forças de Van der Waals. As aplicações mais comuns são na remoção de compostos orgânicos que atribuem gosto, odor e riscos à água de beber, limpeza de gases contendo compostos orgânicos voláteis (COV's), descoloração de alimentos e purificação farmacêutica.

O carvão ativado é um material poroso que contém minúsculos poros internos. A Figura 16 mostra o processo de transporte na adsorção na partícula de adsorvente. Explica Martins (2004), que o poluente é chamado de adsorbato ou simplesmente de sorbato, e o sólido é chamado de adsorvente. A capacidade do adsorvente é expressa por vários índices, tais como área superficial ou distribuição do tamanho do poro. A área superficial é um termo 
relativo e refere-se à área ocupada pelas moléculas adsorvidas na monocamada de cobertura sobre a superfície dentro de um adsorvente.

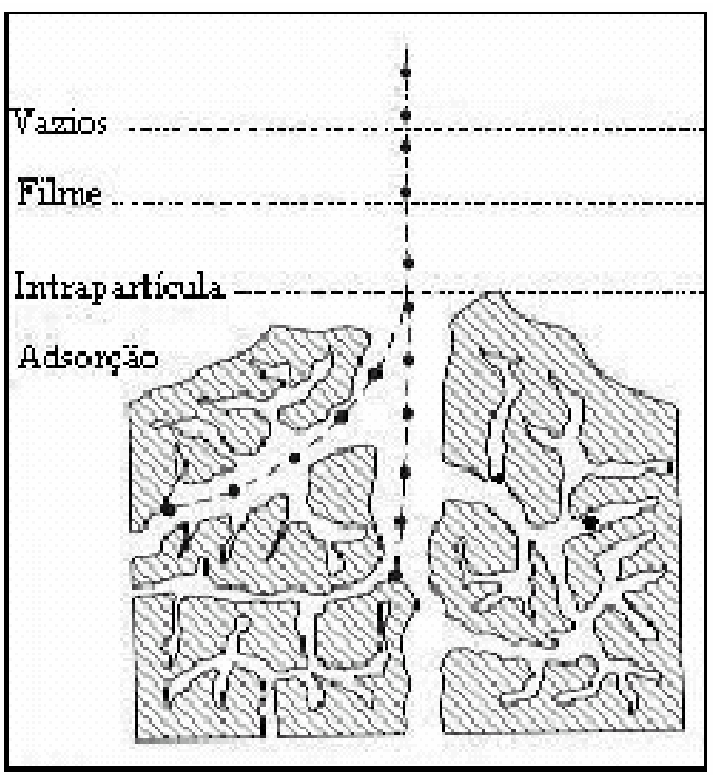

Figura 16 - Processo de transporte no adsorvente

Fonte: adaptado de Martins, 2004

Martins (2004), explica que se utiliza o ar para evitar a fluidização do leito e a abrasão do carvão. A corrente de ar é alimentada no leito no sentido de fluxo para baixo através do equipamento de carvão. O gás entra no topo da superfície do carvão, onde a maioria dos poluentes é removida da corrente de gás antes de atravessar todo o leito. A transferência de massa pode realmente ocorrer somente no topo do carvão.

Após a saturação da superfície do carbono, é necessário que o mesmo seja dirigido a uma regeneração. Segundo Martins (2004), a regeneração é efetivada utilizando calor ou pressão menores para reverter o processo de adsorção. A regeneração a vácuo da atividade do carvão pode ser feita de duas maneiras: regeneração a vácuo somente com uma bomba de vácuo com anel líquido e regeneração a vácuo com bomba de anel líquido e sopradores. A regeneração a vácuo usando somente a bomba de anel líquido remove parcialmente as moléculas de hidrocarbonetos do carvão ativo saturado. Esta regeneração parcial da atividade 
do carvão assegura que ele não se torne muito reativo. A aplicação de sopradores para fazer vácuo na regeneração alcança uma pressão absoluta mais baixa no sistema e, portanto, uma remoção mais profunda de hidrocarbonetos do carvão ativo saturado. Isto resulta numa maior capacidade de adsorção por unidade de volume de carvão. Contudo, esta profunda regeneração do carvão ativo pode torná-lo mais sensível ao superaquecimento na etapa de adsorção, o que prejudicaria o seu desempenho (CONCAWE, 2002).

Martins (2004) cita como vantagens na utilização de carvão ativado a capacidade de recuperar o poluente para o reúso ou venda; a capacidade de operação numa ampla faixa de concentração de poluente; a eficiência de recuperação que pode exceder 98\%, nos casos bem projetados e bem operados; e o longo tempo de vida útil.

Ainda analisa Martins (2004) que existem desvantagem do uso de carvão ativado, por exemplo: não é recomendável a utilização desta técnica se a corrente de gás contiver partículas ou outros materiais que possam entupir o leito adsorvente ou que possam cobrir as partículas individuais do adsorvente; o carvão ativado é inflamável; este material é difícil de regenerar quando o sorbato tem alto ponto de ebulição; ele promove a polimerização ou oxidação de alguns solventes a compostos tóxicos ou insolúveis e requer controle de umidade.

\subsubsection{Biorremediação in situ}

Para Schenk (2004), a biorremediação in situ ocorrerá de forma satisfatória se forem conhecidos e dominados os processo que compõe o sistema, as unidades de extração e tratamento de águas subterrâneas, a dosagem de nutrientes e a re-infiltração das águas no subsolo. 
Conforme este autor, a biorremediação in situ, que envolve o uso de microorganismos naturais para degradar os contaminantes do aqüífero, vem sendo bastante utilizada principalmente pelos baixos custos envolvidos, além de ser uma solução satisfatoriamente viável. Ainda são observados como vantagens a pequena geração de resíduos, o distúrbio mínimo da área, a mínima exposição humana ao material contaminado, potencial reduzido de contaminação cruzada, não ocorrer o esgotamento do aqüífero por bombeamento excessivo e a conversão dos $\mathrm{BTEX}$ em $\mathrm{CO}_{2}$ e $\mathrm{H}_{2} \mathrm{O}$, que são praticamente inofensivos à saúde humana.

Embora apresente as vantagens acima citadas, segundo Schenk, para que esta tecnologia seja utilizada de forma bem sucedida é necessário que o local apresente algumas condições básicas:

a) presença de microorganismos com potencial para biodegradação dos contaminantes;

b) acessibilidade dos poluentes aos microorganismos;

c) indução de enzimas de degradação apropriadas;

d) disponibilidade de receptores de elétrons;

e) disponibilidade de nutrientes inorgânicos;

f) $\mathrm{pH}$ adequado;

g) temperatura adequada; e

h) ausência de substâncias tóxicas.

No entanto, a utilização da gasolina brasileira prejudica algumas destas condições. A presença de etanol causa uma indução das enzimas de degradação dos BTEX à sua própria degradação. Assim, percebe-se que o etanol é degradado muito antes dos compostos BTEX, em efeito diauxico. Quanto ao reagente consumido na biodegradação, dos cinco mais utilizados (oxigênio molecular, nitrato, ferro ferroso, sulfato e dióxido de carbono) dois deles são inviáveis: o oxigênio molecular e o nitrato, pois o etanol utiliza o oxigênio presente para sua degradação e o benzeno é recalcitrante sob condições denitrificantes (ALVAREZ, 2004). 
Outro fator determinante no sucesso da biorremediação é a ausência de fase livre. A flutuação do nível freático, faz com que ocorra uma alteração no desenho da pluma. Se nele houver uma fase livre de contaminante, impedindo a regressão da pluma de contaminação, esta pode causar, por vezes, uma expansão da mesma. A biorremediação tem melhores resultados quando o aqüífero é homogêneo e de alta permeabilidade $\left(>10^{-5} \mathrm{~m} / \mathrm{s}\right)$ (ALVAREZ, 2004).

Embora alguns autores (TECNOHIDRO, 200?; ROCHE, 2006 e NOBRE, M. M. e NOBRE, R. C. M., 2003) citem as tecnologias abaixo relacionadas em classificação distintas, Alvarez (2004) as cita como tipos diferentes de biorremediação:

bioventilação (bioventing) - comumente utilizado para estimular a degradação aeróbia acima do lençol freático. Nesta tecnologia, são utilizadas bombas de vácuo para extração do ar através das zonas insaturadas. Costuma-se utilizar galerias de infiltração para distribuir nutrientes que evitam a dessecação da zona insaturada;

sistema de circulação de água - através deste sistema, retiram-se as águas subterrâneas contaminadas para tratamento em superfície e posteriormente elas são reinjetadas no solo adicionada de aditivos $\left(\mathrm{H}_{2} \mathrm{O}_{2}\right.$ como fonte de oxigênio e outros nutrientes) ;

air sparging - esta tecnologia consiste na injeção de ar comprimido na camada superficial contaminada suprindo-a de oxigênio arrastando os compostos BTEX para um sistema de captura de vapores. No caso do solo não ser de baixa permeabilidade, o que aprisiona e redireciona o fluxo de ar, esta é uma tecnologia bastante eficiente e barata de remediação;

barreiras biológicas - quando as plumas de BTEX são estreitas é possível que seja inserida uma barreira biologicamente ativa incorporada a cortinas de ar para que o oxigênio intensifique o processo de biodegradação oxidativa. Em alguns 
casos pode ser necessário o controle físico ou hidráulico nos movimentos das águas subterrâneas para direcionar os compostos BTEX para a barreira.

Existe um fator que muitas vezes dificulta a biorremediação no Brasil: a heterogeneidade do solo. Este problema complica a distribuição dos reagentes para a biorremediação. Esta tecnologia adapta-se melhor a solos arenosos.

A figura a seguir demonstra o funcionamento do sistema Air Sparging.

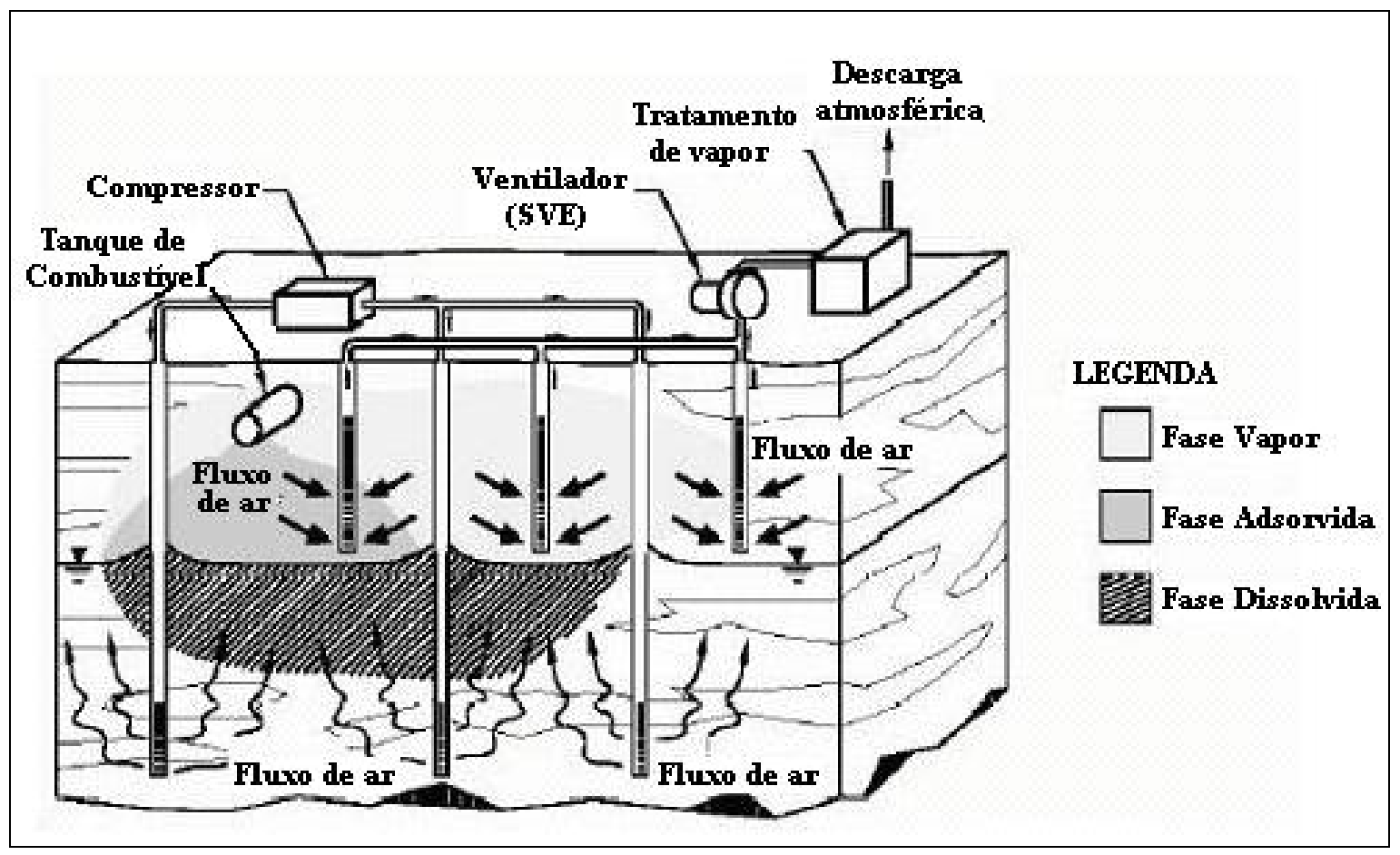

Figura 17 - Sistema Air Sparging associado ao SVE

Fonte: Tecnohidro, 200?

A biorremediação pode ser utilizada para descontaminar tanto o solo quanto a água e se enquadra em duas grandes categorias: in situ e ex situ . Na remediação in situ, o tratamento do solo ou da água subterrânea contaminada é feito no próprio local. É mais eficaz em solos 
permeáveis, como os arenosos. As medidas biocorretivas ex situ consistem em escavar o solo contaminado ou extrair a água subterrânea por bomba para aplicar o tratamento em outro local. Estas apresentam uma maior versatilidade para o tratamento de grande número de contaminantes e tipos de solo (TECNOHIDRO, 200?).

A Figura 18 apresenta um esquema do sistema Biorremediação.

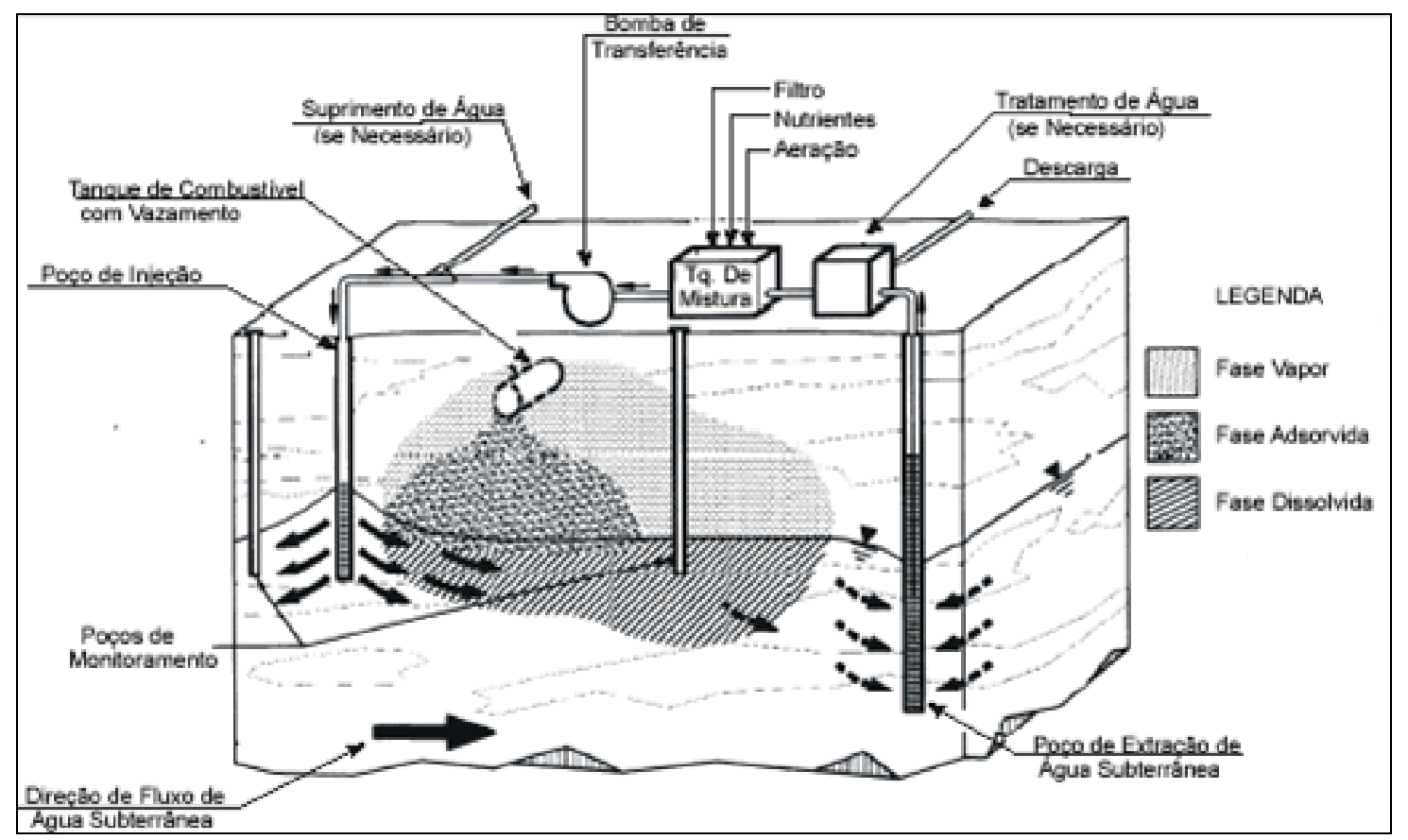

Figura 18 - Sistema Biorremediação in situ

Fonte: Tecnohidro, 200?

\subsubsection{Atenuação natural}

A atenuação natural pode ser considerada uma biorremediação passiva, segundo Alvarez (2004), porém, neste trabalho, optou-se por tratá-la como um outro processo de remediação. Embora possa parecer uma forma de "não fazer nada”, este processo, quando 
aliado à análise de risco, está sendo muito bem aceito por órgãos ambientais no mundo todo. Para que seja eficiente, são necessários estudos que comprovem que o solo possui microorganismos suficientes para eliminar os contaminantes e que haja constante monitoramento da pluma de contaminação (ALVAREZ, 2004).

Este autor define atenuação natural como "combinação de processos naturais biológicos, químicos e físicos que agem sem intervenção humana de forma a reduzir a massa, toxicidade, mobilidade, volume ou concentração dos contaminantes (e.g., biorremediação intrínseca, dispersão, diluição, sorção e volatilização).”

Para que a atenuação natural seja bem sucedida são necessárias as seguintes condições:

a) caracterização adequada da área;

b) plano de monitoramento de longo prazo;

c) avaliação e controle da fonte; e

d) prazo suficiente para que os objetivos da remediação sejam alcançados.

\subsubsection{Injeção de melaço}

A injeção de melaço pode ser considerada um tipo de biorremediação, no entanto, por ser uma tecnologia utilizada muitas vezes como complemento de outras, é preferível tratá-la separadamente. Esta tecnologia consiste em injetar uma mistura de água com melaço (fonte de carbono) para promover uma zona redutora para as bactérias anaeróbicas (FURTADO, 2005).

Para tratamento de contaminações de gasolina com etanol, pode-se exemplificar com a 
utilização da injeção de melaço - que é um concentrado de nutrientes e doador de elétrons, muitas vezes somado a água removida da pluma e tratada por filtro de carvão ativado e desinfetada por peróxido e hidrogênio e UV. O peróxido de hidrogênio deve ser usado com baixa concentração. Portanto não é oxidante para o meio e ainda atua como liberador de oxigênio. A engenharia do programa faz com que o sistema funcione como uma "barreira biológica”, ao mesmo tempo em que o MPE controla a pluma.

A vantagem desta tecnologia é não provocar, como nos processos de oxidação, a geração de subprodutos indesejados, sobretudo em metais (FURTADO, 2005).

\subsubsection{Extração de vapores do solo (SVE)}

O Sistema de Extração de Vapores no Solo (SVE) é uma tecnologia de remediação aplicada para zona não saturada (TECNOHIDRO, 200?). Esta tecnologia consiste na aplicação de vácuo com o objetivo de induzir o fluxo de ar a remover contaminantes voláteis e semivoláteis do solo.

O gás retirado pela extração de vapores do solo deve passar por uma unidade de tratamento de vapores. Extrações verticais são utilizadas em profundidades que variam de 1,5 a $90 \mathrm{~m}$. Extrações horizontais (instaladas em trincheiras ou furos horizontais) podem ser instaladas para aumentar a segurança, dependendo da geometria da pluma e outras especificidades (TECNOHIDRO, 200?).

O rebaixamento do lençol freático pode ser utilizado para reduzir a elevação do nível d'água no poço induzido pelo vácuo ou aumentar a faixa de zona não saturada. A injeção de ar é efetiva para facilitar a extração de contaminantes em profundidades com baixa 
permeabilidade e em zona saturada.

Os contaminantes que são extraídos por meio do uso desta tecnologia são: os compostos orgânicos voláteis (COV’s) e alguns combustíveis. A extração de vapores do solo é aplicada somente para compostos voláteis com constante da Lei de Henry acima de 0,01 ou pressão de vapor maior que 0,5 mm $\mathrm{Hg}$ (0,02 polegadas de $\mathrm{Hg})$. Outros fatores, como umidade e quantidade de matéria orgânica, afetam a permeabilidade de ar no solo e, por conseqüência, a eficiência do sistema. O fato de o processo envolver fluxo contínuo de ar no solo promove biodegradação in situ dos compostos de baixa volatilidade que podem estar presentes (TECNOHIDRO, 200?).

Os dados necessários incluem a profundidade e a área de extensão da contaminação, a concentração de contaminantes, a profundidade do nível d'água, o tipo de solo e as propriedades do mesmo (estrutura, textura, permeabilidade e umidade). Ensaios piloto devem ser realizados para obter informações de desenho, incluindo raio de influência dos poços de extração, taxas de fluxo de gás, vácuo ótimo aplicado e taxas de remoção de contaminantes.

A Figura 19 a seguir ilustra um típico sistema de extração de vapores. 


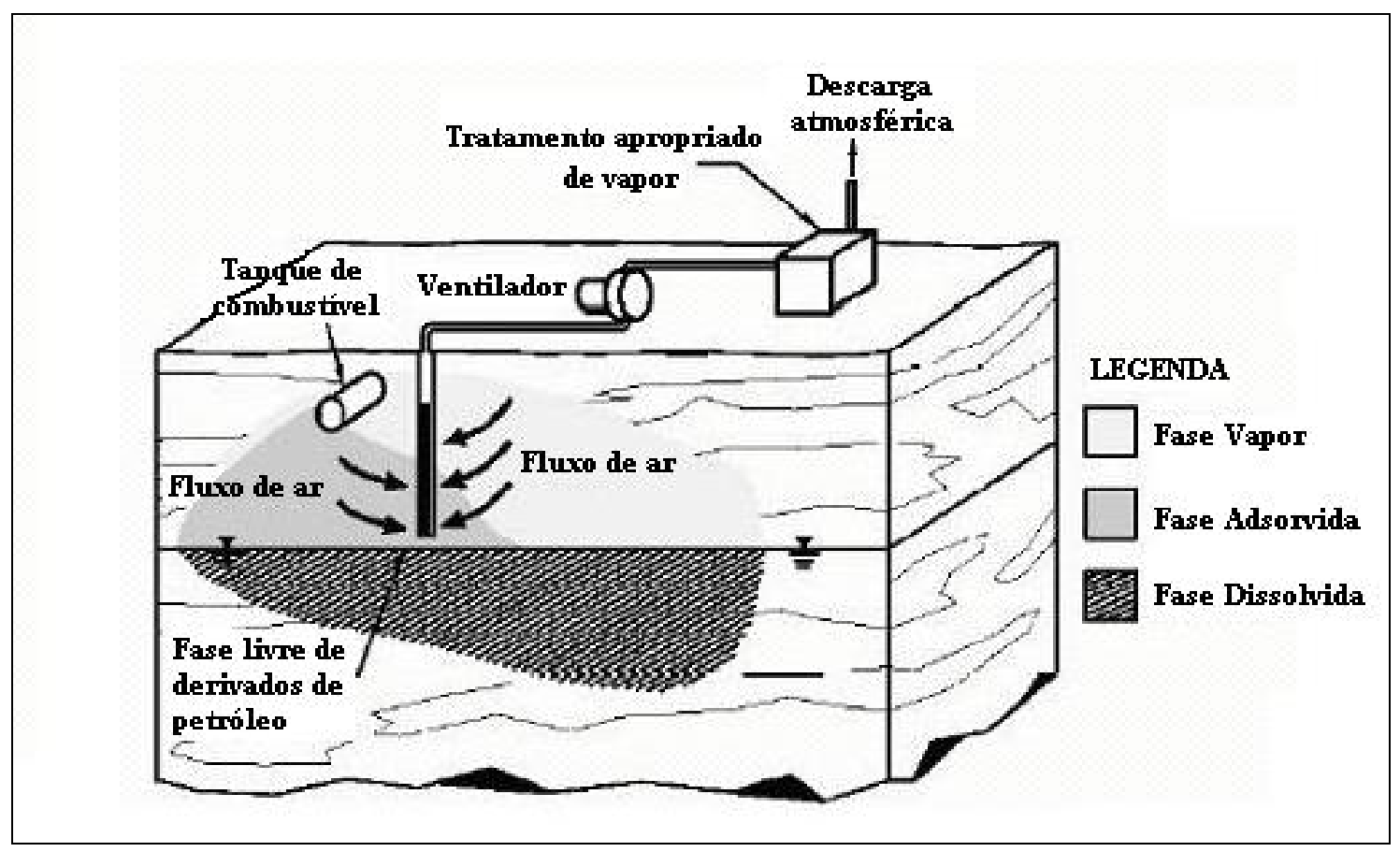

Figura 19 - Sistema de Extração de Vapores

Fonte: Tecnohidro, 200?

Conforme Ackermanm (2004), a extração de vapores do solo (SVE) não deve ser utilizada em solos densos, pois é necessário que ocorra uma ventilação eficiente nos poros. Outro fator que limita a eficiência das operações de SVE é a subpressão. Existem ainda outros fatores limitantes da utilização desta tecnologia (TECNOHIDRO, 200?):

os solos com permeabilidades variáveis podem resultar em envio de fluxo de gás para regiões não contaminadas, uma vez que grandes intervalos de filtro são necessários nos poços de extração;

os solos com alto índice de matéria orgânica ou extremamente secos apresentam alta capacidade de absorção de COV's, o que resulta em redução de taxas de remoção;

o controle da emissão gasosa pode ser necessário para eliminar possíveis danos ao público e ao meio ambiente; 
o resultado da produção de efluentes gasosos, líquidos residuais e resíduos, poderá requerer tratamento com carvão ativado; e

SVE não é efetivo em zona saturada. Porém, pode-se conjugar o rebaixamento do lençol freático para ocorrer maior exposição de zona não saturada.

No entanto, apesar das limitações, esta é uma tecnologia de baixo custo e pode ser resumida em: escavação de solo contaminado, pilha de solo escavado envolta em plástico, instalação de poços de SVE na pilha e extração de gás (ACKERMANM, 2004).

\subsubsection{Barreiras reativas in situ}

A Barreira hidráulica pode ser convencional ou reativa - que tem um custo muito mais alto (SCHENK, 2004). As dificuldades encontradas com os sistemas de contenção hidráulica convencionais - Pump \& Treat - leva ao uso de tecnologias alternativas para melhorar o desempenho do sistema e reduzir o custo total do projeto de remediação, esta saída vem se tornando uma prática cada vez mais comum em projetos de reabilitação de aqüíferos (NOBRE, M. M. e NOBRE, R. C. M., 2003).

Uma das opções de remediação é a utilização de barreiras reativas. O projeto é uma obra de engenharia propriamente dita, já que consiste em instalar no subsolo, a jusante da fonte de contaminação, uma parede subterrânea (FURTADO, 2005). O sistema deve ser projetado de forma que seja favorecida a passagem das águas subterrâneas através de porções reativas - que podem ser aeróbicas ou anaeróbicas para reações mediadas biologicamente - é uma tentativa de fazer melhor uso das tecnologias naturais, de forma a acelerar as reações (NOBRE, M. M. e NOBRE, R. C. M., 2003). 
Na Figura 20, pode-se observar um exemplo de barreiras reativas permeáveis.

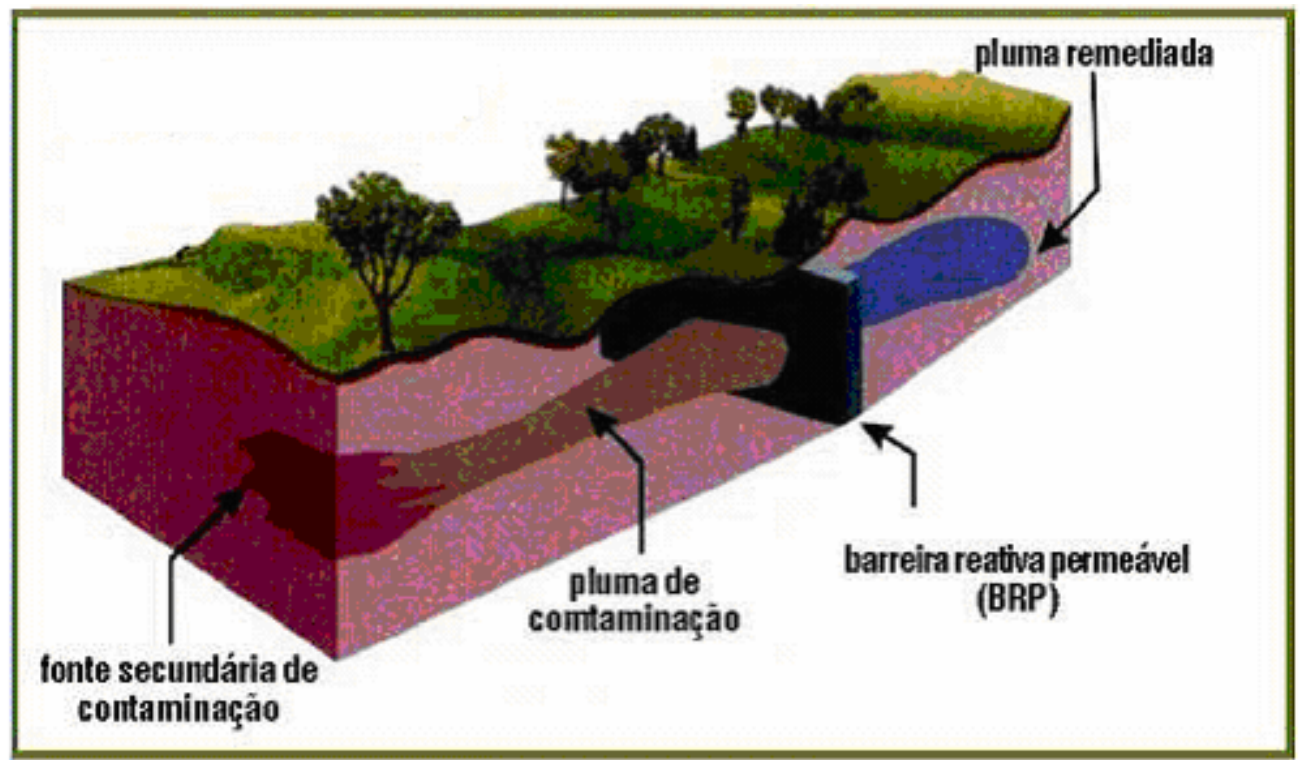

Figura 20 - Representação esquemática de barreiras reativas permeáveis (BRP) Fonte: Nobre, M. M.e Nobre, R. C. M., 2003

As barreiras reativas permeáveis (BRP’s), incluindo os sistemas funnel-and-gate, são considerados técnicas de remediação passiva ou destruição de massa in situ. A tecnologia das BRP’s vem sendo utilizada de forma cada vez maior nos Estados Unidos e Canadá e é considerada uma das alternativas de remediação de maior preferência no mercado, conforme assinala Nobre, M. M. e Nobre, R. C. M. (2003). O padrão de evolução das tecnologias vem focalizando em soluções cada vez mais naturais, incluindo a alteração das condições bioquímicas do subsolo para subsidiar na remediação.

Uma das opções mais utilizadas nas BRP’s é a adição de ferro com valência zero (ALVAREZ, 2004), zinco ou sulfato ferroso (NOBRE, M. M. e NOBRE, R. C. M., 2003) . 


\subsubsection{Extração multifásica (MPE) ou bioslusping}

A Extração Multi-fásica (MPE), tecnologia de remediação no local também conhecida como extração de fase dupla ou bioslurping, segundo Roche (2006), consiste no bombeamento para a remoção de produto em fase livre, água subterrânea com compostos dissolvidos e vapor do solo. É uma tecnologia eficiente quanto à redução da concentração de hidrocarbonetos na zona não saturada do solo. Em locais em que o nível da água não é muito profundo, o bombeamento da fase livre e dissolvida é realizado por meio da aplicação de vácuo nos poços de extração. Quando o nível da água subterrânea atinge profundidade superior a 10 m, recomenda-se a utilização de um sistema que combine a extração de vapores por vácuo com o bombeamento convencional do produto em fase livre e da água subterrânea.

Ackermanm (2004) afirma que esta tecnologia de remediação apresenta uma vantagem sobre o bombeamento simples, pois esta permanece operacional mesmo se a superfície das águas subterrâneas estiver abaixo do ponto de sucção e o ar entrar no tubo de sucção.

Na tecnologia de extração multifásica (MPE) são combinadas bombas de vácuo para extrair vapores e água subterrânea para remover a fase líquida e gasosa do mesmo poço (FURTADO, 2005).

\subsubsection{Fitorremediação}

A fitorremediação, segundo Nobre, M. M. e Nobre, R. C. M. (2003), consiste em plantar vegetais apropriados para promover a extração e/ou biodegradação de contaminantes 
orgânicos ou metais no solo. É uma tecnologia aceita pela EPA (STIER, 2004).

Dinardi et al. (2003) enumeram diferentes categorias de fitorremediação: fitoextração, fitoestabilização, rizofiltração, barreiras hidráulicas, capas vegetais, açudes artificiais fitoestimulação, fitodegradação e fitovolatilização, sendo os três últimos utilizados na remediação de áreas contaminadas por hidrocarbonetos.

Na Figura 21, pode-se observar um esquema de como a planta trata o contaminante.

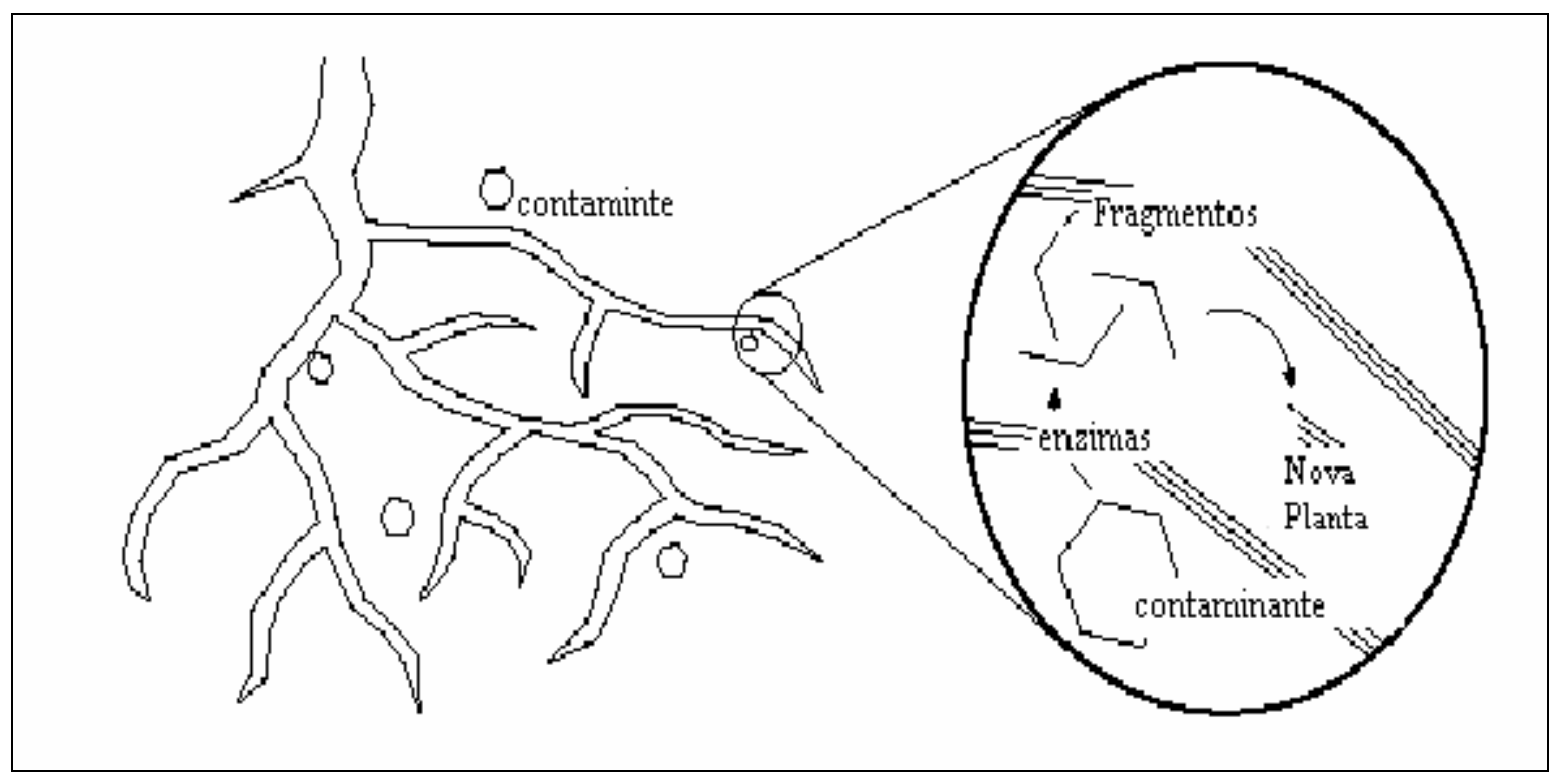

Figura 21 - Representação esquemática de fitodegradação de poluentes.

Fonte: Dinardi et al., 2003

Os autores supra citados enumeram como vantagens da utilização de fitorremediação o fato de poder tratar de diversas maneiras grandes áreas, a baixo custo, com possibilidade de remediar solo, subsolo e águas e, ao mesmo tempo, embelezar o ambiente. No entanto, como desvantagens são apresentadas o longo tempo necessário, o controle das concentrações dos contaminantes para que não comprometa o tratamento e a possibilidade da vegetação entrar na cadeia alimentar do ambiente. 


\subsubsection{Oxidação in situ}

Oxidação in situ é uma tecnologia baseada na injeção de oxidantes químicos em meios contaminados (água subterrânea e solo), com o objetivo de destruir o contaminante através de reações químicas e converter a sua massa em compostos inertes encontrados na natureza (TECNOHIDRO, 200?).

Comenta-se que a oxidação in situ é muito empregada na remediação de solo e água subterrânea. Ela pode ser aplicada a diversos tipos e granulometria de solos (silte e argiloso), no tratamento de compostos orgânicos voláteis (COV’s), incluindo dicloroeteno (DCE), tricloroetileno (TCE), tetracloroetileno (PCE), benzeno, tolueno, etilbenzeno e xilenos, assim como os compostos orgânicos semi-voláteis (SCOV's) tais como os pesticidas, hidrocarbonetos policíclicos aromáticos (HPA’s) e as bifenilas policloradas (PCB’s).

Os oxidantes usualmente aplicados neste processo são: peróxido de hidrogênio $\left(\mathrm{H}_{2} \mathrm{O}_{2}\right)$, permanganato de potássio $\left(\mathrm{KMnO}_{4}\right)$, ozônio $\left(\mathrm{O}_{3}\right)$ e em menor escala o oxigênio dissolvido (OD). O cuidado na utilização do $\mathrm{KMnO}_{4}$, é o seu potencial de ionização, que deve ser suficientemente elevado para quebrar o contaminante (ALVAREZ, 2004).

Conforme Furtado (2005) em solos muito argilosos, onde é difícil a injeção de nutrientes utiliza-se, comumente, processos oxidativos avançados (POA), utilizando agente “Fenton” (peróxido de hidrogênio + catalisador). Normalmente, é utilizado o ferro como agente catalisador, o que gera radicais hidroxilas livres, que oxidam os compostos orgânicos presentes no meio. O peróxido de hidrogênio residual decompõe-se em água e oxigênio e o ferro sofre precipitação. Esta inserção é um processo mais rápido, que deve ser aplicado quando não há fase livre de contaminante (TECNOHIDRO, 200?). 


\subsubsection{Sistema de recuperação de fase livre por skimming}

Skimmer - anglicismo de uso comum na literatura - consiste no equipamento que é inserido na interface hidrocarboneto/água e promove a captação exclusiva da fase livre. Este equipamento pode estar associado à uma bomba que promove a retirada do produto continuadamente e, neste caso, é denominado skimmer ativo, ou possuir um recipiente com capacidade entre 1,5 e $6 \mathrm{~L}$, que deve ser constantemente monitorado e esvaziado - skimmer passivo (MILLER, 2001).

Através da utilização do skimmer, faz-se a extração de fase livre, ou seja, contaminante puro, através da aplicação de vácuo (NOBRE,M. M. e NOBRE, R. C. M., 2003). Este método estimula a biodegradação sem a extração de águas subterrâneas.

\subsubsection{Desadsorção termal}

A desadsorção termal é uma técnica de remediação ex situ também conhecida como Dessorção Termal, Volatilização Térmica em Baixas Temperaturas, Dissociação Térmica e Aquecimento Controlado de Solo (TECNOHIDRO, 200?). Esta tecnologia consiste em separar fisicamente hidrocarbonetos de solos escavados utilizando para tanto calor. Conforme o endereço eletrônico da Tecnohidro (200?), dissociadores térmicos são projetados com o intuito de aquecer solos a temperaturas suficientes para causar a volatilização dos compostos e dissociá-los (separar fisicamente) do solo, sem que haja alteração em suas propriedades físicas. Dependendo dos compostos orgânicos presentes e da temperatura do sistema, estes 
podem ser decompostos parcial ou completamente pelos dissociadores térmicos, embora esta não seja sua função. O objetivo principal é permitir a disposição do solo em seu local de origem ou em uma nova utilização.

Após a volatilização, os hidrocarbonetos são geralmente tratados em uma unidade de tratamento secundária, que podem ser câmaras de oxidação catalítica, condensadores, ou unidade de adsorção de carbono, só então são liberados na atmosfera. Nas câmaras de oxidação, ocorre a destruição dos compostos orgânicos, já nos condensadores e unidades de adsorção de carbono os compostos orgânicos ficam capturados para posterior tratamento ou disposição (TECNOHIDRO, 200?).

Algumas consultorias ambientais, possuem sistema móvel de dessorção termal, que é montado sobre carretas, podendo ser transportado, instalado e utilizado com rapidez para atendimento em vários locais, possibilitando tratamento on site e off site.

Conforme o endereço eletrônico da Essencis (200?), este sistema de tratamento apresenta como vantagens:

custo competitivo;

tempo de tratamento menor devido à capacidade da unidade;

tratamento no local para áreas com grande volume de solo contaminado;

solos tratados podem ser recolocados no local de origem ou em uma nova utilização;

possibilidade de utilização também em solos com elevadas concentrações de hidrocarbonetos de petróleo; e 
capacidade para reduzir o BTEX- Benzeno Tolueno, Etilbenzeno e Xilenos para menos de 500 ppb e o TPH -Teor de Hidrocarboneto Total de Petróleo-para menos de 500 ppm.

A Figura 22 mostra um esquema de desadsorção térmica móvel. 


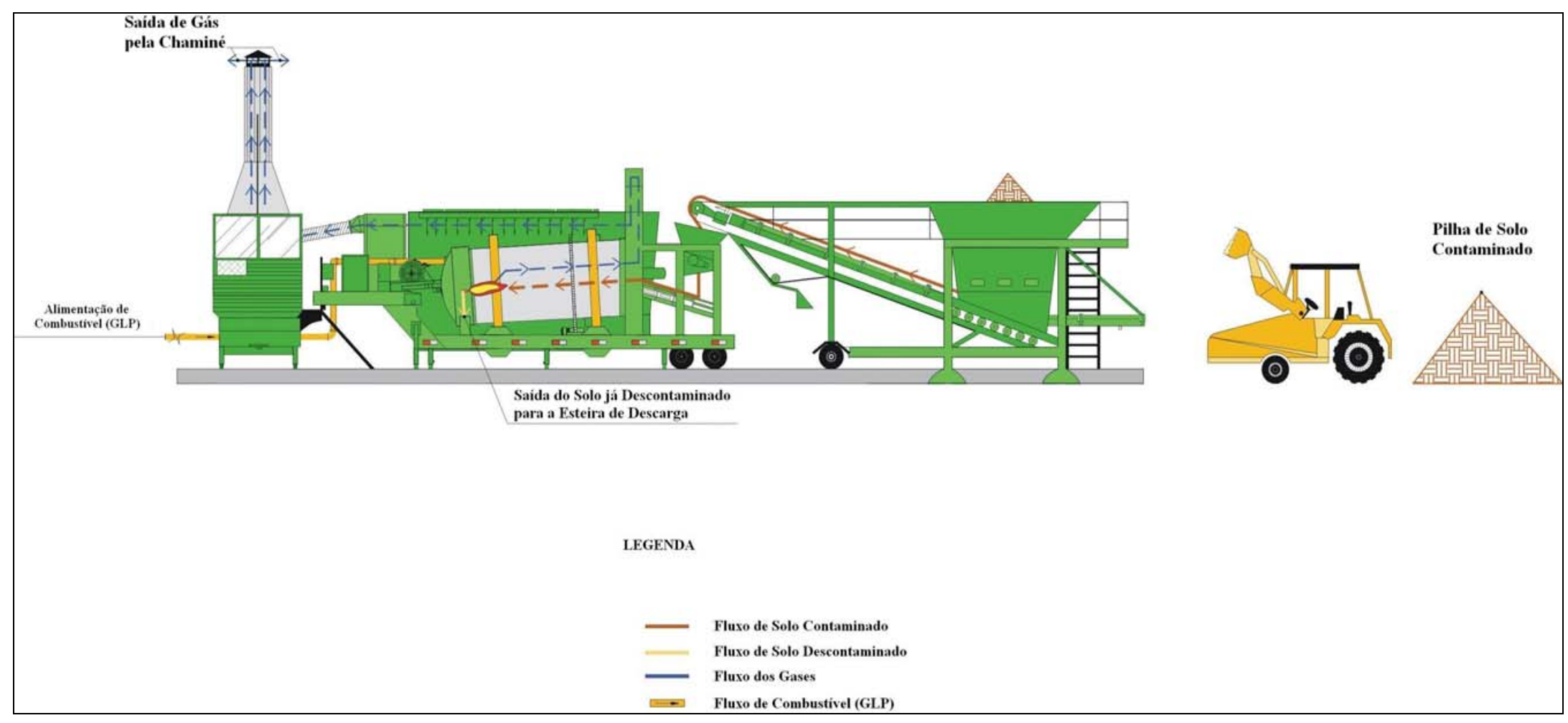

Figura 22 - Esquema de desadsorção térmica móvel

Fonte: Essencis, 200? 


\subsubsection{Lavagem de solo}

A lavagem de solo através de fluidos apropriados promove a "estripagem” e a biodegradação, conforme cita Nobre, M. M. e Nobre, R. C. M. (2003). Através dela, inseremse compostos químicos para acelerar a transferência de fases do contaminante.

A adição de surfactantes através da lavagem de solo, por exemplo, reduz a tensão superficial entre os contaminantes e a água, promovendo a mobilização da fase residual e imiscível a ser extraída (NOBRE, M. M. e NOBRE, R. C. M., 2003). Após o tratamento da água contaminada, algumas metodologias de remediação, induzem a reinjeção destas águas no aqüífero. No entanto, esta reinjeção pode acelerar o processo de dissolução dos contaminantes bem como de outros mecanismos, como a desorção ou processos de oxidação. 


\section{MATERIAIS E MÉTODOS}

O número reduzido de trabalhos a respeito de remediações de áreas contaminadas por hidrocarbonetos provenientes de vazamentos em instalações de postos de gasolina, bem com a ausência de metodologias satisfatórias nas remediações atualmente existentes, serviram como motivação para execução deste estudo.

Através da análise realizada no Cadastro de Áreas Contaminadas (CETESB, 2005), foram selecionados aleatoriamente 5 casos para estudo detalhado da documentação existente nos processos de licenciamento ambiental e/ou de reclamações da população existentes na Cetesb - Agência Ambiental de Guarulhos.

O objetivo deste trabalho consiste não em refazer as análises realizadas pela equipe técnica da Cetesb, mas apresentar e discorrer sobre as opções tecnológicas que podem ser utilizadas baseadas nos dados relativos à contaminação, apresentados pelas empresas de consultoria e análises laboratoriais, contratadas pelos estabelecimentos comerciais e/ou "bandeira”3 para investigação das áreas contaminadas por vazamentos oriundos das instalações destes postos. Para a realização desta pesquisa verificou-se a situação atual das contaminações, tais como: dimensões das plumas de contaminação, a ocorrência de remediação na área, qual o tipo de remediação, entre outras informações.

Como citado anteriormente, no Cadastro de Áreas Contaminadas (CETESB, 2005), estão relacionados 36 casos de contaminação por postos de combustíveis no município de Guarulhos. Dos 5 casos escolhidos, 2 deles apresentam-se nas etapas de investigação confirmatória e os outros 3 com remediação em andamento (nov. 2005). Em cada um dos

\footnotetext{
${ }^{3}$ Bandeira é a empresa responsável pela comercialização dos combustíveis para o posto, ou seja, é a distribuidora de combustíveis. Ex.: BR, ESSO, Ipiranga, SHELL, Texaco, entre outras.
} 
casos foi analisado o mapeamento das contaminações existentes e já identificadas, o quanto as águas subterrâneas já foram atingidas e o quanto a população está exposta a estas contaminações.

Segundo Lopes et al. (2001), quando, através da análise de risco é constatada que a população está exposta ao risco, faz-se necessário o desenvolvimento de um plano de remediação. Para que a escolha dos processos de remediação seja mais correta possível é necessário que a investigação da área contaminada e a avaliação de risco tenha sido efetivadas cuidadosamente e apresentem exatamente a situação do local. Através do levantamento realizado, constatou-se que foram contratadas várias empresas diferentes para realizar as análises de risco, análises químicas e físicas, estudos de passivo ambiental, confecção do projeto de remediação e a remediação propriamente dita, assim, cada uma destas empresas será denominada neste trabalho por Consultoria A, Consultoria B, Consultoria C, sucessivamente.

A seguir estão descritos os históricos de cada um dos estabelecimentos estudados e a evolução de suas contaminações assim como as discussões a respeito de cada caso. Os 5 postos serão denominados: Caso 1, Caso 2, Caso 3, Caso 4 e Caso 5. Na Figura 23 há uma demarcação aproximada cada um deles no mapa de Guarulhos. 


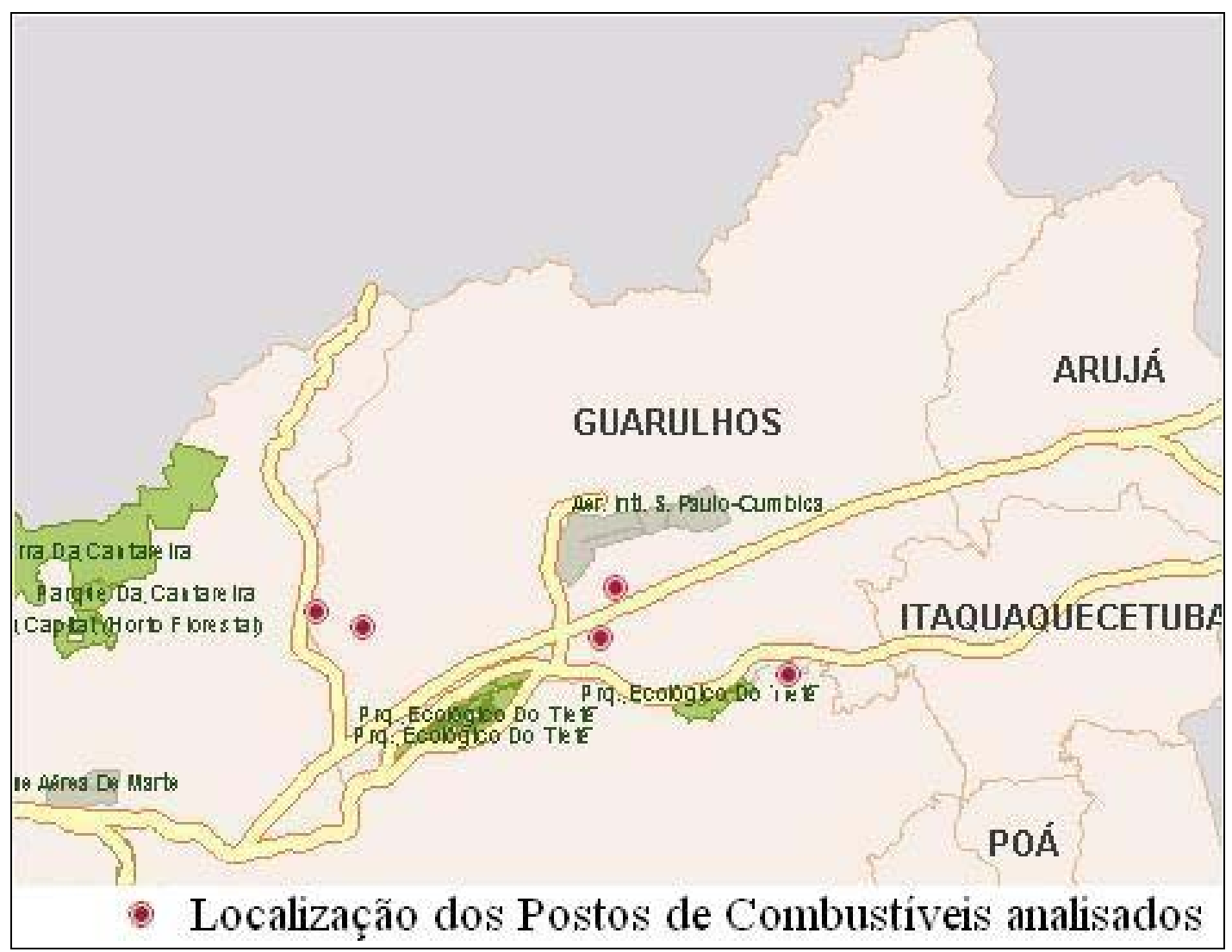

Figura 23 - Município de Guarulhos - demarcação aproximada dos postos analisados Fonte: adaptado de Maplink, 200?

A Figura 24 mostra uma imagem de satélite da cidade de Guarulhos em 2006, com a sobreposição dos casos estudados. Nesta figura, é possível observar que ao Norte do município há cobertura de matas, o que deixa a localização dos postos de combustíveis com maior concentração ao Sul. Desta forma é possível perceber, que embora a densidade demográfica da cidade de Guarulhos seja de 3141,64 habitantes por km², existe um maior número de pessoas concentrados ao Sul do município, tornando a exposição ao problema das áreas contaminadas por hidrocarbonetos provenientes de vazamentos em postos de combustíveis, muito mais abrangente do que se imaginava em princípio. 


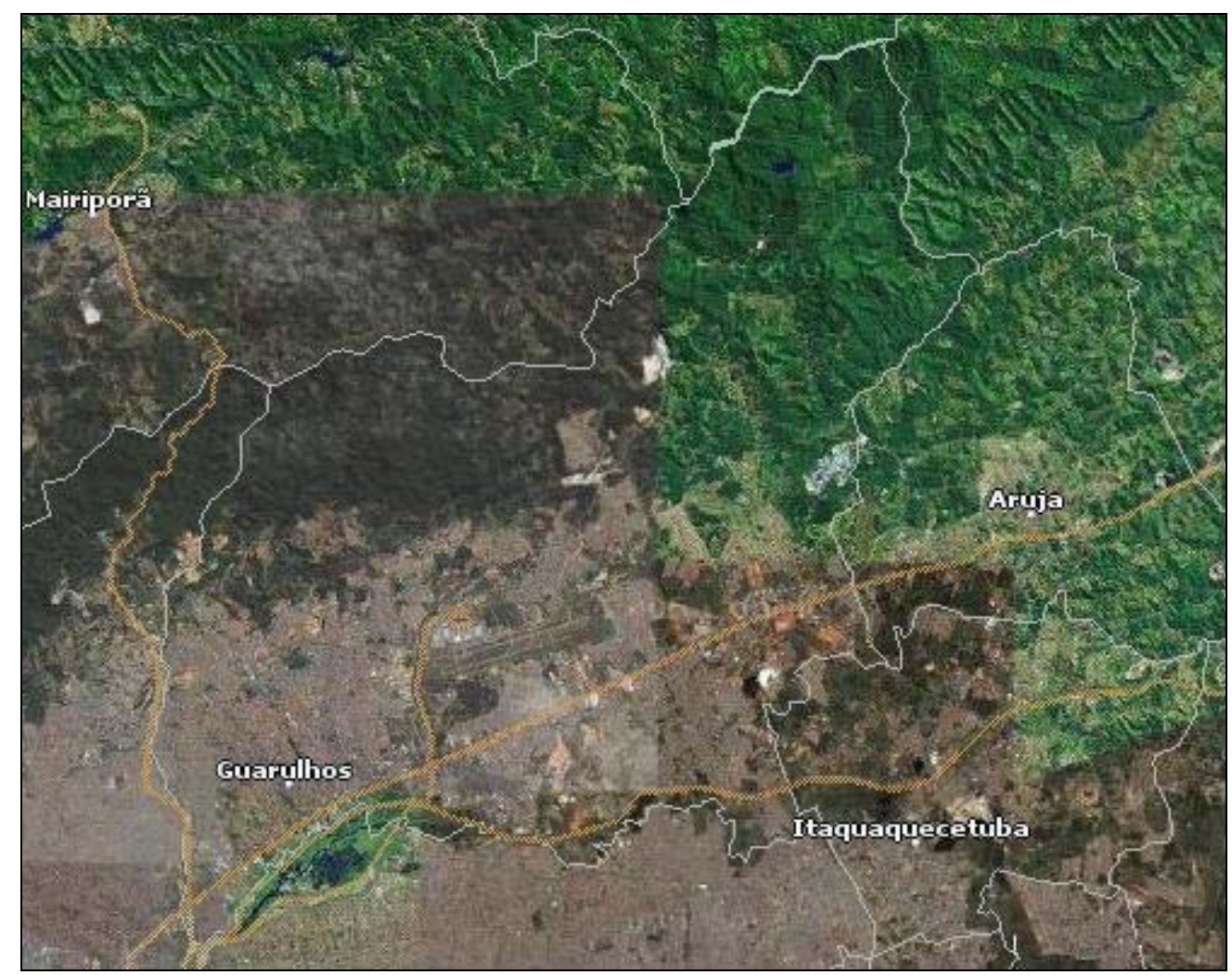

Figura 24 - Imagem de satélite do município de Guarulhos

Fonte: adaptado de GuiaMais online, 200?

\subsection{CASO 1}

O Caso 1 refere-se a um posto que está localizado na Vila Galvão e possui bandeira branca, ou seja, não há predominância de nenhuma marca comercial de combustível no estabelecimento. Este fato, muitas vezes dificulta na escolha de uma tecnologia de remediação, pois quando além do dono do posto há o comprometimento da bandeira, é mais fácil o levantamento da verba necessária para a descontaminação. Segundo os relatórios apensados no processo existente na Cetesb, a área total do terreno é de 720,0 m² e o local 
sempre foi posto de combustível, sem a existência de outro tipo de construção antes disto. As instalações comerciais do posto são compostas por loja de auto-peças, loja de som e alarmes e loja de conveniência, além da atividade de troca de óleo. A tancagem do posto, antes da reforma, era composta por 1 tanque de $30,0 \mathrm{~m}^{3}$ bicompartimentado ${ }^{4}$ e 3 tanques de 30,0 $\mathrm{m}^{3}$ plenos $^{5}$, nos quais são armazenados: álcool, diesel, gasolina comum e gasolina aditivada. A média mensal de combustíveis comercializados é 80.000 L de gasolina, 40.000 L de álcool e 25.000 L de diesel.

Na região, a ocupação do solo é predominantemente comercial, no entanto há existência de poço cacimba na vizinhança, num raio de 100,0 m de distância do estabelecimento, o que o coloca na Classe 2, segundo a classificação da ABNT-NBR 13.786. Esta situação mostra uma população bastante exposta à contaminação, pois a utilização de poço para captação de águas subterrâneas é um agravante, mesmo que a maioria do solo seja de utilização comercial.

Como características da geologia local, pode-se dizer que o embasamento na área do Caso 1 é composto pela Suíte Granítica e pelo Grupo Açungui (Complexo Embu e Complexo Pilar). A litoestratigrafia da Formação São Paulo é composta por estratos de argilas, siltes e areias argilosas finas intercalados entre si. Há esporádica ocorrência de lentes de areias grossas e cascalho fino. O Caso 1 está situado sobre os depósitos aluvionares do Quaternário que são compostos por areias inconsolidadas de granulação variável, argilas e cascalheiras fluviais.

A investigação da Geologia Local foi realizada por meio de sondagens a trado concha e as amostras foram descritas litoestratigraficamente como aterro de areia argilo siltosa, cor cinza, lado a lado com um solo arenoso-argiloso de coloração marrom escuro avermelhado.

\footnotetext{
${ }^{4}$ Bicompartimentado é um tanque que possui dois compartimentos separados para armazenagem de combustíveis diferentes.

${ }^{5}$ Pleno é um tanque que possui apenas armazenagem de um único tipo de combustível de cada vez.
} 
Ocorre também presença de entulho e cristais de rocha, com estado friável e úmido. Este solo é encontrado até a profundidade máxima de 0,85 metros; - no ponto PS01 encontra-se uma argila arenosa, cor cinza escura. A matriz silte argilosa é composta por minerais de quartzo e opacos com granulometria muito fina à fina e apresenta boa seleção de grãos sub-angulosos, o estado é plástico e úmido. A espessura desta camada é de aproximadamente 0,75 m. A camada de areia siltosa cor cinza claro é composta por cristais de quartzo, feldspato e minerais opacos. Apresenta ainda granulometria de fina a grossa, com boa seleção, subangulosos. Estado friável e úmido. A espessura da camada é de aproximadamente 0,09 m.

O sistema hidrogeológico é composto por rochas sedimentares da Bacia de São Paulo. A superfície potenciométrica é o lugar geométrico dos pontos que marcam as alturas potenciométricas de um aqüífero, referidas a uma dada profundidade. O nível d'água encontrado varia de 1,0 a 1,87 m. O Mapa Potenciométrico (Figura 25) foi obtido a partir da interpolação dos dados de carga hidráulica, obtidos a partir da cota 730,0 m estimada. com base na interpolação destes dados desenhou-se as curvas equipotenciais e perpendiculares, as mesmas foram traçadas as direções de fluxo de Sudeste para Noroeste. A análise deste mapa evidencia que a direção preferencial do fluxo da água subterrânea acompanha a topografia da superfície em direção ao Rio Cabuçu de Cima ou Guapira, com carga hidráulica média de 728,35 m sobre o nível do mar. O aqüífero foi caracterizado como de caráter livre a semiconfinado.

Em junho de 2003 o Caso 1 apresentou o Relatório de Investigação de Passivos Ambientais em postos de combustíveis realizada pela Consultoria A. Na área objeto deste estudo não há ocorrência de galerias subterrâneas de águas pluviais ou de água potável, mas há rede de água e esgoto sob responsabilidade do Serviço Autônomo de Água e Esgoto (SAAE) de Guarulhos. Não existem registros de gasodutos, fiações elétricas ou sistemas outros que possam ser considerados riscos iminentes. Na amostragem de campo para a 
realização deste Relatório de Investigação de Passivos Ambientais, foi observado forte odor de combustível durante a amostragem e presença de fase livre de combustível. Em julho do mesmo ano, o Caso 1 recebeu um Auto de Infração - Imposição de Penalidade de Advertência (AIIPA) por não ter solicitado o licenciamento ambiental junto à Cetesb. 


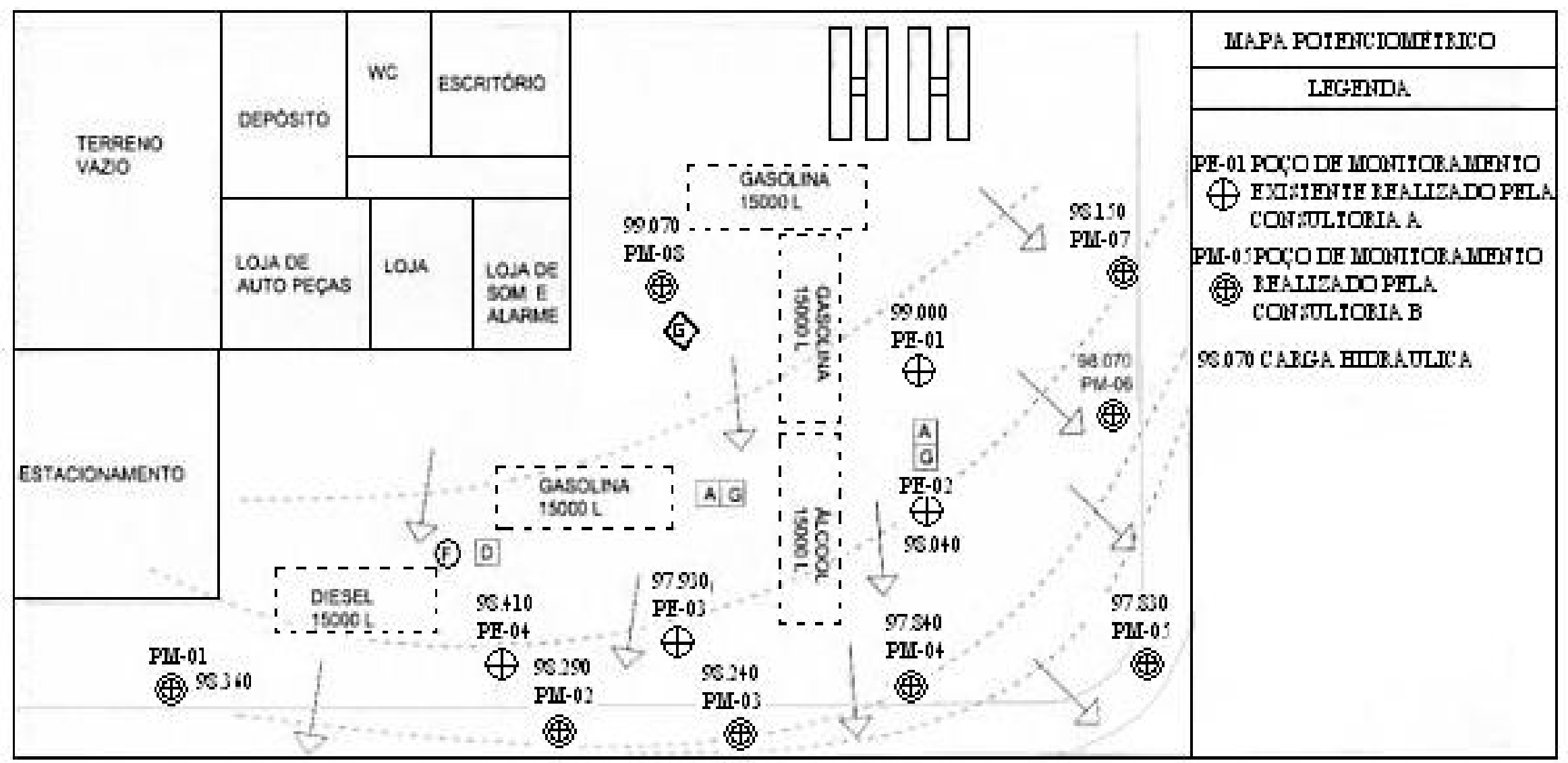

Figura 25 - Caso 1 - Mapa potenciométrico 
Ainda neste relatório, concluiu-se que: todas as concentrações dos compostos de interesse encontradas na água subterrânea oferecem risco à saúde humana, pois os valores obtidos excederam os valores orientadores para solo e água dos Estado de SP - Anexo C para um cenário industrial. Estes valores orientadores, baseavam-se na Portaria $n^{\circ} 1469$ de 28/01/2000, conforme pode ser observado na Tabela 6 que apresenta os resultados obtidos na análise de água da coleta realizada em 22 de maio de 2003.

Tabela 6 - Caso 1 - Análise de água subterrânea (maio de 2003)

\begin{tabular}{cccccc}
\hline Local & $\begin{array}{c}\text { Benzeno } \\
(\boldsymbol{\mu g} / \mathrm{L})\end{array}$ & $\begin{array}{c}\text { Tolueno } \\
(\boldsymbol{\mu g} / \mathrm{L})\end{array}$ & $\begin{array}{c}\text { Etilbenzeno } \\
(\boldsymbol{\mu g} / \mathrm{L})\end{array}$ & $\begin{array}{c}\text { o-Xileno } \\
(\boldsymbol{\mu g} / \mathrm{L})\end{array}$ & $\begin{array}{c}\text { P + m-xilenos } \\
(\boldsymbol{\mu g} / \mathrm{L})\end{array}$ \\
\hline PM-02 & $\mathbf{1 6 5 9 4 , 2 0}$ & $\mathbf{1 4 9 7 0 , 7 0}$ & $\mathbf{1 8 5 5 , 4 0}$ & $\mathbf{4 5 3 5 , 1 0}$ & $\mathbf{5 0 1 2 6 , 0 0}$ \\
PM-03 & $\mathbf{3 5 8 3 0 , 4 0}$ & $\mathbf{7 1 2 6 0 , 1 0}$ & $\mathbf{2 1 5 3 8 , 9 0}$ & $\mathbf{4 4 8 4 9 , 9 8}$ & $\mathbf{1 6 4 2 2 8 , 4 0}$ \\
$\begin{array}{c}\text { Valores } \\
\text { orientadores }^{6}\end{array}$ & 5,00 & 170,00 & - & 300,00 & 300,00 \\
\end{tabular}

Na Tabela 7, encontram-se os valores obtidos quando da análise de solo da amostra coletada em 22 de maio de 2003. A tabela mostra que os valores são muito acima dos valores orientadores para solos e águas subterrâneas no estado de São Paulo.

Tabela 7 - Caso 1 - Análise de solo (maio de 2003)

\begin{tabular}{|c|c|c|c|c|c|}
\hline Local & $\begin{array}{c}\text { Benzeno } \\
(\mu \mathrm{g} / \mathrm{kg})\end{array}$ & $\begin{array}{l}\text { Tolueno } \\
\text { ( } \mu \mathrm{g} / \mathrm{kg})\end{array}$ & $\begin{array}{c}\text { Etilbenzeno } \\
(\mu \mathrm{g} / \mathrm{kg})\end{array}$ & $\begin{array}{c}\text { o-Xileno } \\
\text { ( } \mu \mathrm{g} / \mathrm{kg})\end{array}$ & $\begin{array}{c}p+\text { m-xilenos } \\
(\mu \mathrm{g} / \mathrm{kg})\end{array}$ \\
\hline PM-02 & 2000,00 & 392,74 & 2210,00 & 552,58 & 1000,00 \\
\hline $\begin{array}{c}\text { Valores } \\
\text { orientadores }^{7}\end{array}$ & 11,5 & 40,00 & 40,00 & 6,00 & 6,00 \\
\hline
\end{tabular}

\footnotetext{
${ }^{6}$ Portaria ${ }^{\circ} 1469$ de 28/01/2000 - Qualidade de água para consumo humano

${ }^{7}$ Valores orientadores para solos e águas subterrâneas no estado de SP (CETESB, 2001) - Anexo C
} 
Em setembro de 2004 ocorreu a concessão de Licença Prévia e Licença de Instalação por parte da Cetesb, baseada na documentação e nas informações fornecidas pelo proprietário do estabelecimento. Nesta data também ocorreu a assinatura do Termo de Ajuste de Conduta (TAC) entre o proprietário e a Cetesb. Esta era uma prática comum de comprometimento para descontaminação da área afetada. ${ }^{8}$ Em novembro de 2004, foi juntada ao processo de licenciamento na Cetesb a investigação detalhada realizada pela Consultoria B.

Em maio de 2005, a Consultoria B, em correspondência, forneceu uma informação contraditória, dizendo que durante a investigação detalhada não existia fase livre, no entanto, alguns parágrafos depois, na mesma carta, relata que após esta investigação iniciou-se a remoção de fase livre nos poços de monitoramento PM 03 e PM 04. O total de combustível recuperado com esta operação foi de 400,0 L de fase livre, encaminhado para uma empresa reprocessadora de óleo.

No final do ano de 2005, mais precisamente em novembro e dezembro, ocorreu a troca de tanques: 2 de 30,0 $\mathrm{m}^{3}$ para gasolina; 1 de 30,0 $\mathrm{m}^{3}$ - bicompartimentado para álcool; 1 de 30,0 $\mathrm{m}^{3}$ - bicompartimentado para gasolina aditivada e diesel. Ainda em dezembro do mesmo ano, a Consultoria B apresentou Relatório de Avaliação de Risco à Saúde Humana, que foi elaborado com base na ACBR. Os furos para análise do solo foram realizados com trado manual. Neste relatório, a consultoria manteve a informação contraditória já notada na correspondência de maio deste ano quanto à existência de fase livre. Para o caso do Posto em questão, os cenários válidos on site foram detectado como sendo vapores provenientes da água subterrânea contaminada, perceptíveis em ambiente externo. Este quadro pode ser prejudicial aos funcionários do posto além de existir a possibilidade de futuros operários de obras ingerirem, inalarem ou estarem em contato dérmico com a contaminação retida no solo. Assim, no Caso 1, o modelamento analítico utilizado para concluir a análise foi executado

\footnotetext{
${ }^{8}$ A utilização do Termo de Ajuste de Conduta - TAC, deixou de ser obrigatória em dezembro de 2004, através de uma decisão da diretoria.
} 
para estes cenários de interesse. Na Figura 26 está delimitada a contaminação em termos de concentrações de COV. Nesta figura é possível perceber que a maior concentração estava localizada próxima aos poços existentes, PE-02 e PE-03, no entanto, esta delimitação foi realizada antes da reforma. Na Figura 27, é possível observar-se a localização dos tanques subterrâneos de armazenamento após a reforma realizada em 2005.

Uma outra contradição, notada durante a análise do Caso 1, é que, no RBCA a Consultoria B afirmou que os efluentes dirigem-se ao SAO (sistema de separação água e óleo) e em outra página diz que os efluentes são dispostos na rede pública de esgotos. Esta contradição impede de que se tenha certeza de que os efluentes resultantes da atividade desenvolvidos no local estejam sendo tratados e dispostos corretamente. O SAO é um sistema de tratamento que requer uma disposição final do efluente, que nesta situação deve ser a rede pública de esgotos, no entanto, da forma como está descrito nos relatórios é impossível afirmar que é assim que ocorre neste posto. 


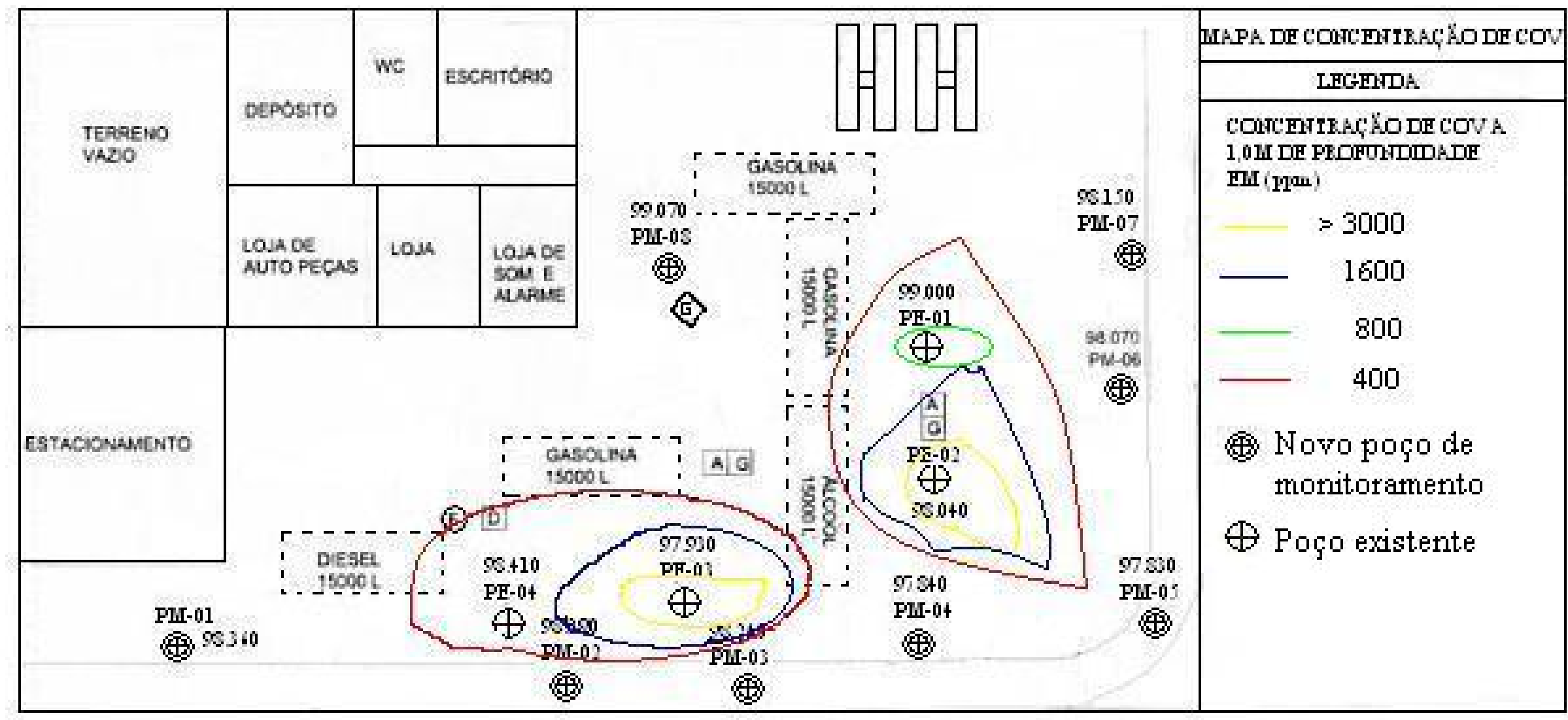

Figura 26 - Caso 1 - Delimitação da pluma de contaminação 


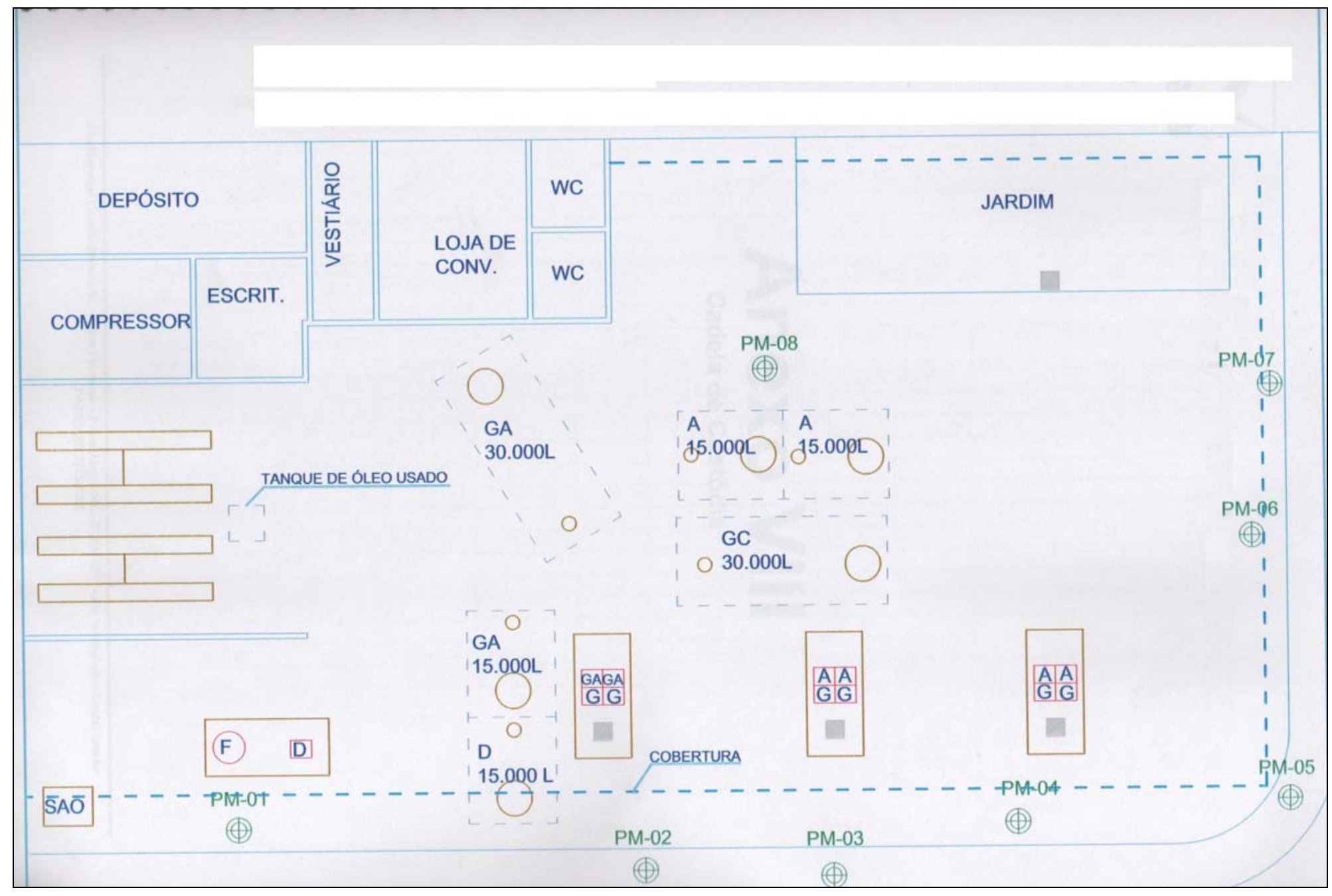

Figura 27 - Caso 1 - Localização dos tanques após a reforma 
Na Tabela 8 é possível notar que os valores, obtidos quando da análise de amostras de água subterrânea coletadas em maio de 2005, pela Consultoria B, encontravam-se abaixo dos valores admissíveis pela Portaria nº 1469 de 28/01/2000 - Qualidade de água para consumo humano. No entanto, na correspondência protocolizada pela Consultoria B, datada deste mesmo mês, foi dito que “iniciou-se a remoção de fase livre após as investigações”, conforme já descrito anteriormente, porém não informou como e qual o equipamento foi utilizado para esta remoção. A ausência de um projeto de remediação e estas informações contraditórias e incompletas são obstáculos para que seja possível uma análise da remediação que está ocorrendo no local.

Tabela 8 - Caso 1 - Análise de água subterrânea (maio de 2005)

\begin{tabular}{cccccc}
\hline Local & $\begin{array}{c}\text { Benzeno } \\
(\boldsymbol{\mu g} / \mathbf{L})\end{array}$ & $\begin{array}{c}\text { Tolueno } \\
(\boldsymbol{\mu g} / \mathbf{L})\end{array}$ & $\begin{array}{c}\text { Etilbenze } \\
\mathbf{n o}(\boldsymbol{\mu g} / \mathbf{L})\end{array}$ & $\begin{array}{c}\text { o-Xileno } \\
(\boldsymbol{\mu g} / \mathbf{L})\end{array}$ & $\begin{array}{c}\mathbf{P}+\mathbf{m}-\mathbf{x i l e n o s} \\
(\boldsymbol{\mu} \mathrm{g} / \mathbf{L})\end{array}$ \\
\hline PM-01 & $<4,0$ & $<4,0$ & $<4,0$ & $<4,0$ & $<4,0$ \\
PM-02 & $<4,0$ & $<4,0$ & $<4,0$ & $<4,0$ & $<4,0$ \\
PM-03 & $<4,0$ & $<4,0$ & $<4,0$ & $<4,0$ & $<4,0$ \\
PM-04 & $<4,0$ & $<4,0$ & $<4,0$ & $<4,0$ & $<4,0$ \\
PM-05 & $<4,0$ & $<4,0$ & $<4,0$ & $<4,0$ & $<4,0$ \\
Valores & 5,00 & 170,00 & - & 300,00 & 300,00 \\
orientadores $^{9}$ & & & & &
\end{tabular}

O Caso 1 utilizou o serviço de mais 6 empresas além das consultorias já citadas. Estas empresas foram contratadas para elaboração do projeto para reforma do posto, instalação dos tanques, testes de estanqueidade, análises laboratoriais e disposição adequada dos resíduos provenientes desta operação, no entanto, embora já esteja efetuando remoção de fase livre, até junho de 2006 não havia sido apresentado um plano de remediação para este posto.

\footnotetext{
${ }^{9}$ Portaria n 1469 de 28/12/2000 - Qualidade de água para consumo humano
} 


\section{2. $\quad$ CASO 2}

O posto referente ao Caso 2 está localizado no bairro dos Pimentas e possui bandeira Ipiranga associada a ele. A área total do terreno é de 710,0 $\mathrm{m}^{2}$. O local é provido de galeria de drenagem de águas pluviais, rede de água e esgoto e rede elétrica.

O estabelecimento promove troca de óleo. A tancagem do posto era composta por 4 tanques de 15,0 $\mathrm{m}^{3}$ sendo 2 de gasolina comum, 1 de álcool e 1 de diesel e mais 1 tanque de 10,0 m³ também para diesel. Existe controle diário do volume dos tanques através de controle eletrônico e a movimentação média mensal é de 68,0 m³ de gasolina, 70,0 m³ de álcool e 45,0 $\mathrm{m}^{3}$ de diesel.

Na região, a ocupação do solo é predominantemente residencial. Há uma favela em cota inferior ao posto, no entanto não há registro de poço de captação de água subterrânea na vizinhança, nem de hospitais, num raio de 200,0 m de distância do estabelecimento. Somente no posto existe de um poço cacimba que se encontra desativado.

Em um dos relatórios apresentados, o Caso 2 declara que é abastecido por rede pública de água e esgoto. Porém, no estudo de passivo ambiental apresentado pela Consultoria $C$ e na ACBR, foi informado que é utilizado fossa séptica e poço absorvente para disposição de efluentes.

A inspeção realizada para o relatório de passivo ambiental deu-se em 10 de abril de 2003, pela Consultoria C. Os 4 poços perfurados para coleta de material a ser enviado para análise, foram realizados com a utilização de trado manual. Os resultados constantes deste documento são: índices de explosividade com valores nulos com relação ao Limite Inferior de Explosividade (LIE); não foram detectados valores de BTEX, nem PAH acima dos padrões de referência no solo além dos poços de monitoramento PM-03 e PM-04. Na Tabela 9, pode-se observar que os valores de concentração obtidos nas análises das amostras coletadas nesta 
fase não excedem os padrões de referência seja da Cetesb (2001) ou os Risk-Based Screening Level (RBSL) calculados para o empreendimento.

Tabela 9 - Caso 2 - Análise de solo (abril de 2003)

\begin{tabular}{|c|c|c|c|c|c|c|}
\hline \multirow[b]{2}{*}{ Parâmetros } & \multirow[b]{2}{*}{$\begin{array}{c}\text { SD - 1/8,0 } \\
(\mu \mathrm{g} / \mathrm{kg})\end{array}$} & \multirow[b]{2}{*}{$\begin{array}{c}\text { SD - 2/11,0 } \\
(\mu \mathrm{g} / \mathrm{kg})\end{array}$} & \multirow[b]{2}{*}{$\begin{array}{c}\mathrm{SD}-3 / 10,0 \\
(\mu \mathrm{g} / \mathrm{kg})\end{array}$} & \multirow[b]{2}{*}{$\begin{array}{c}S D-4 / 10,0 \\
(\mu \mathrm{g} / \mathrm{kg})\end{array}$} & \multicolumn{2}{|c|}{ Padrões de referência } \\
\hline & & & & & $\begin{array}{l}\text { Cetesb } \\
(\mu \mathrm{g} / \mathrm{kg})\end{array}$ & $\begin{array}{l}\text { RBSL }^{10} \\
(\mu \mathrm{g} / \mathrm{kg})\end{array}$ \\
\hline Ben & $<1,00$ & $<1,00$ & $<1,00$ & $<1,00$ & 1500,0 & 15,0 \\
\hline Tolueno & $<1,00$ & $<1,00$ & $<1,00$ & $<1,00$ & 40000,0 & 37000,0 \\
\hline Etilbenzeno & $<1,00$ & $<1,00$ & $<1,00$ & $<1,00$ & ne & 36000,0 \\
\hline Xilenos totais & $<1,00$ & $<1,00$ & $<1,00$ & $<1,00$ & 6000,0 & 480000,0 \\
\hline
\end{tabular}

Na Tabela 10 estão relacionados os valores de concentração obtidos nas amostras de água subterrânea para os diferentes poços de monitoramento em uso no posto. Nesta, pode-se observar que a água coletada no PM-03 apresentou valor acima do recomendado pela Portaria n 1469/00 para o parâmetro benzeno, enquanto que o PM-04, como exceção do parâmetro xileno, todos os compostos BTEX apresentaram valores acima dos admissíveis.

Tabela 10 - Caso 2 - Análise de água subterrânea (abril de 2003)

\begin{tabular}{cccccc}
\hline Parâmetros & $\begin{array}{c}\text { PM-01 } \\
(\mu \mathbf{g} / \mathbf{L})\end{array}$ & $\begin{array}{c}\text { PM-02 } \\
(\mu \mathbf{g} / \mathbf{L})\end{array}$ & $\begin{array}{c}\text { PM-03 } \\
(\mu \mathbf{g} / \mathbf{L})\end{array}$ & $\begin{array}{c}\text { PM-04 } \\
(\mu \mathbf{g} / \mathbf{L})\end{array}$ & $\begin{array}{c}\text { Portaria } \\
\mathbf{1 4 6 9} / \mathbf{0 0}(\mu \mathbf{g} / \mathbf{L})\end{array}$ \\
\hline Benzeno & $<1,00$ & $<1,00$ & $\mathbf{1 6 , 9 6}$ & $\mathbf{5 2 , 8 4}$ & 5,0 \\
Tolueno & $<1,00$ & $<1,00$ & $<1,00$ & $\mathbf{2 9 2 , 3 8}$ & 170,0 \\
Etilbenzeno & $<1,00$ & $<1,00$ & $<1,00$ & $\mathbf{5 0 , 2 4}$ & - \\
Xileno & $<1,00$ & $<1,00$ & $<1,00$ & 138,79 & 300,0
\end{tabular}

Na Figura 28 pode-se observar a localização dos poços de monitoramento (PM), bem como das instalações dos tanques antes da reforma. Nos PM-03 e PM-04, foram detectados,

\footnotetext{
${ }^{10}$ RBSL - Risk-Based Screening Level para solo superficial em área residencial
} 


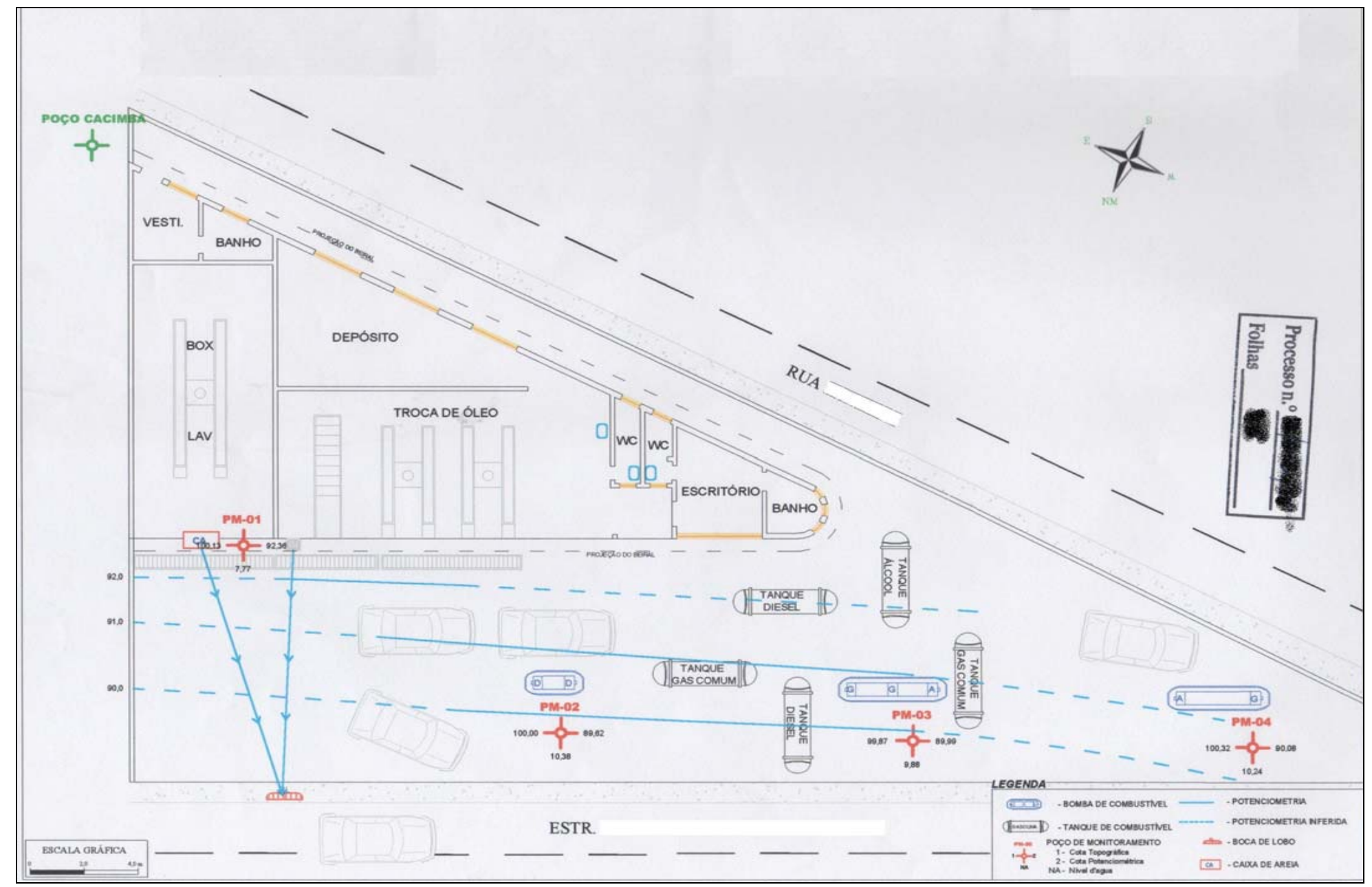

Figura 28 - Caso 2 - Mapa potenciométrico 
presença de benzeno e tolueno em concentrações acima dos valores permitidos na água. Não foi detectada presença de PAH na água, acima dos padrões. Portanto, é possível concluir que existe contaminação, provavelmente de gasolina, na região da pista de abastecimento do posto.

No solo há predominância de argila, localmente arenosa e micácea, marrom a vermelha, com intercalações de areia fina vermelha e amarela. O sentido do fluxo para água subterrânea com orientação de Sul para Norte.

O estabelecimento em questão recebeu um AIIPA da Cetesb, em junho de 2003 por não atender à convocação para licenciamento e reforma, que deveria ter ocorrido até 30 de abril de 2003 e, em fevereiro de 2004, foi novamente advertido por não atender a correspondência.

Em julho de 2004, ocorreu a assinatura do TAC. E iniciou-se a reforma, com substituição dos tanques, sendo que foram colocados 2 tanques de $30,0 \mathrm{~m}^{3}$, sendo 1 bicompartimentado para gasolina aditivada e álcool, 1 pleno para gasolina comum e 1 tanque pleno de 15,0 $\mathrm{m}^{3}$ para diesel. Instalou-se ainda, 1 tanque de 3,0 $\mathrm{m}^{3}$ para armazenamento de óleo lubrificante usado, além da instalação de Gás Natural Veicular (GNV). Em agosto do mesmo ano, foram concedidas pela Cetesb, as Licenças Prévia e de Instalação para o empreendimento. E em abril de 2005 recebeu uma Licença de Operação à Título Precário com validade de 180 dias.

Em monitoramento entregue em outubro de 2005 (efetuado em julho do mesmo ano), constatou-se presença de fase livre de combustível somente no PM-10, bastante distante do local onde estavam localizados os PM-03 e PM-04, que apresentaram contaminações no Laudo de Passivo Ambiental entregue anteriormente. A Consultoria D, no monitoramento apresentado, manteve a informação de que, segundo os proprietários ou responsáveis pelos estabelecimentos localizados nas adjacências do posto, não existe captação de água subterrânea no entorno. Informou ainda que o nível d’água mínimo medido foi de 8,64 m 
(PM-08) e o máximo foi de 11,69 m (PM-07). O gradiente hidráulico obtido é bastante elevado, variando de 22 a 31\%. Neste mesmo monitoramento, consta a informação de que houve remoção de 17,41 L de fase livre através de amostrador acrílico.

Nos monitoramentos apresentados em novembro de 2005, janeiro e abril de 2006, ainda pode ser observado fase livre no PM-10 que continua sendo removida através de amostrador acrílico.

Em dezembro de 2004 e janeiro de 2005, foi efetuada coleta de dados para estudo da Avaliação de Risco pela Consultoria D. Nesta análise concluiu-se que a pluma de fase dissolvida possui 25,0 m de largura e espessura de 2,0 m. No PM-10, foram detectados no solo 359,7 $\mu$ g de xilenos, (Tabela 11) além de traços de naftaleno, acenafteno, acenaftaleno, fluoreno, fenantreno, antraceno, fluoranteno, pireno e criseno, e recomendou-se acompanhamento trimestral da qualidade da água subterrânea por 1 ano. As informações constantes no processo de controle de poluição na Cetesb - Agência de Guarulhos, constam os resultados das análises dos parâmetros PAH's, que podem indicar contaminação por diesel, porém, os parâmetros que interessam a este estudo são os BTEX, anotados nas Tabelas 11 e 12 a seguir. Valores estes utilizados para elaboração do RBCA para o Caso 2. Estas tabelas, baseiam-se nos valores orientadores para solos e para águas subterrâneas no Estado de São Paulo para intervenção industrial, porém, mesmo se os valores de referência fossem os residenciais, ainda assim, não seriam superados.

Com a reforma realizada a partir de dezembro de 2004, ocorreu a destruição dos PM01 a PM-04, assim, a Consultoria D instalou os poços PM-05, PM-06, PM-07, PM-08, PM09, PM-10 e PM-11. Durante a perfuração dos poços, as medições de COV’s apresentaram concentrações nulas, com exceção das medições provenientes da sondagem para a instalação no PM-07 que apresentou valor máximo de 10 ppm. No PM-10 a somatória das concentrações de PAH's obtidas no solo, ultrapassa os valores estabelecidos pela Lista Holandesa ${ }^{11}$, além de

\footnotetext{
${ }^{11}$ Lista Holandesa - Anexo B
} 
apresentar concentrações de benzeno acima dos valores de intervenção preconizados pela listas utilizadas como referência quando da análise de água. A Figura 29, mostra a localização do PM-12 (adicional) que foi utilizado para a possível demarcação da pluma de contaminação no local, segundo a RBCA apresentada.

Na Figura 28 estão demarcadas as instalações dos tanques de combustíveis antes da reforma ocorrida, já na Figura 29, os tanques demarcados são após a reforma.

O Caso 2 foi incluído na Classe 4 quanto a ABNT-NBR 13.786, pois a área contaminada não está associada a qualquer risco potencial à saúde humana, à segurança ou ao meio ambiente. Porém, ainda assim, a análise RBCA impõe como restrição a não-instalação de poços de captação de água subterrânea no local.

Conforme a RBCA efetuada, as concentrações dos compostos de interesse encontradas no solo e na água subterrânea não oferecem riscos à saúde humana, considerando-se tanto os cenários atuais quanto os cenários hipotéticos. 
Tabela 11 - Caso 2 - Análise de solo (fevereiro de 2005)

\begin{tabular}{|c|c|c|c|c|c|c|c|c|c|}
\hline \multirow[t]{2}{*}{ Parâmetros } & \multirow{2}{*}{$\begin{array}{l}\text { PM-05 } \\
(\mu \mathrm{g} / \mathrm{kg})\end{array}$} & \multirow{2}{*}{$\begin{array}{l}\text { PM-06 } \\
(\mu \mathrm{g} / \mathbf{k g})\end{array}$} & \multirow{2}{*}{$\begin{array}{l}\text { PM-07 } \\
(\mu \mathrm{g} / \mathrm{kg})\end{array}$} & \multirow{2}{*}{$\begin{array}{l}\text { PM-08 } \\
(\mu \mathrm{g} / \mathrm{kg})\end{array}$} & \multirow{2}{*}{$\begin{array}{l}\text { PM-09 } \\
(\mu \mathrm{g} / \mathrm{kg})\end{array}$} & \multirow{2}{*}{$\begin{array}{l}\text { PM-10 } \\
(\mu \mathrm{g} / \mathrm{kg})\end{array}$} & \multirow{2}{*}{$\begin{array}{l}\text { PM-11 } \\
(\mu \mathrm{g} / \mathrm{kg})\end{array}$} & \multicolumn{2}{|c|}{$\begin{array}{c}\text { Valores de referência para solo } \\
(\mu \mathrm{g} / \mathrm{kg})\end{array}$} \\
\hline & & & & & & & & Lista Holandesa & Cetesb (2001) \\
\hline Benzeno & 1,00 & $<1$ & $<1$ & $<1,00$ & $<1,00$ & $<1,00$ & $<1,0$ & 1.000 & 3.000 \\
\hline Tolueno & $<1,00$ & 25,98 & $<1,00$ & $<1,00$ & $<1$ & & & 130.000 & 140.000 \\
\hline Etilbenzeno & $<1,00$ & $<1,00$ & $<1,00$ & $<1,00$ & $<1,00$ & $<1,00$ & $<1,00$ & 50.000 & ne \\
\hline Xileno & $<1,00$ & $<1,00$ & $<1,00$ & $<1,00$ & $<1,00$ & 359,70 & $<1,00$ & 25.000 & 15.000 \\
\hline
\end{tabular}

ne: limites não estabelecidos pelas listas de referência

Tabela 12 - Caso 2 - Análise de água subterrânea (fevereiro de 2005)

\begin{tabular}{cccccccccc}
\hline Parâmetros & $\begin{array}{c}\text { PM-05 } \\
(\mu \mathbf{g} / \mathbf{L})\end{array}$ & $\begin{array}{c}\text { PM-06 } \\
(\mu \mathbf{g} / \mathbf{L})\end{array}$ & $\begin{array}{c}\text { PM-07 } \\
(\mu \mathbf{g} / \mathbf{L})\end{array}$ & $\begin{array}{c}\text { PM-08 } \\
(\mu \mathbf{g} / \mathbf{L})\end{array}$ & $\begin{array}{c}\text { PM-09 } \\
(\mu \mathbf{g} / \mathbf{L})\end{array}$ & $\begin{array}{c}\text { PM-10 } \\
(\mu \mathbf{g} / \mathbf{L})\end{array}$ & $\begin{array}{c}\text { PM-11 } \\
(\mu \mathbf{g} / \mathbf{L})\end{array}$ & $\begin{array}{c}\text { Valores de referência para água } \\
(\mu \mathbf{g} / \mathbf{L})\end{array}$ \\
\hline Benzeno & $<1,00$ & $<1,00$ & $<1,00$ & $<1,00$ & $<1,00$ & $<1,00$ & $<1,00$ & 30 & 5 \\
Tolueno & $<1,00$ & $<1,00$ & $<1,00$ & $<1,00$ & $<1,00$ & $<1,00$ & $<1,00$ & 1.000 & 170 \\
Etilbenzeno & $<1,00$ & $<1,00$ & $<1,00$ & $<1,00$ & $<1,00$ & $<1,00$ & $<1,00$ & 150 & ne \\
Xileno & $<1,00$ & $<1,00$ & $<1,00$ & $<1,00$ & $<1,00$ & 39,07 & $<1,00$ & 70 & 300
\end{tabular}

ne: limites não estabelecidos pelas listas de referência 


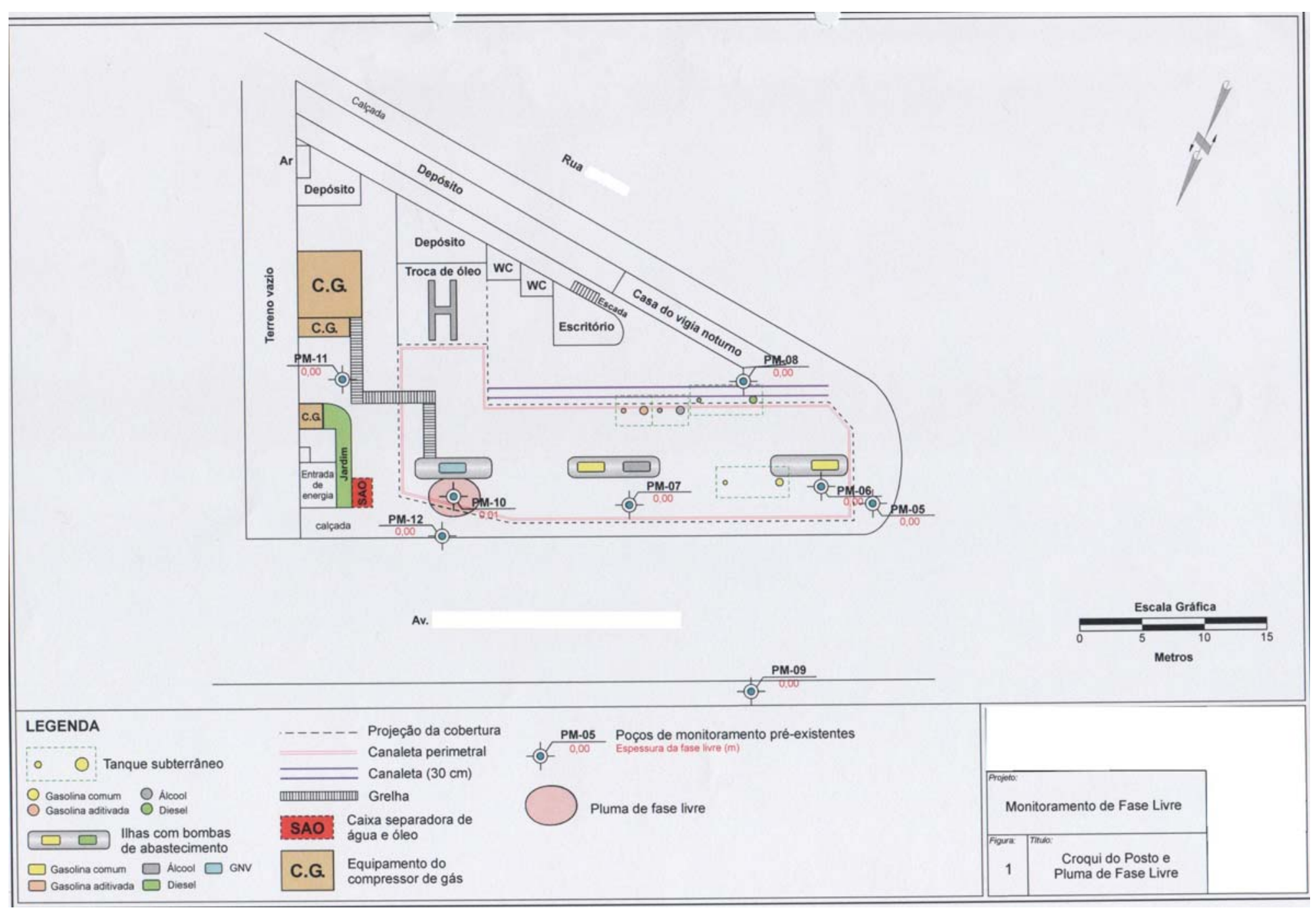

Figura 29 - Caso 2 - Delimitação da pluma de contaminação 
Em janeiro de 2006, o posto em questão recebeu nova Licença de Operação a Título Precário válida por mais 180 dias, até que fossem cumpridas as exigências referentes ao projeto de remediação.

Nos monitoramentos apresentados para o Caso 2 constam os volumes (em litros) recuperados mensalmente através da remoção de fase livre no PM-10, conforme relacionado na Tabela 13.

Tabela 13 - Caso 2 - Volume de combustível recuperado no PM-10

\begin{tabular}{ccc}
\hline Ano & Mês & Volume (L) \\
\hline & Abr & 7,85 \\
& Mai & 0,65 \\
& Jun & 6,43 \\
$\mathbf{2}$ & Jul & 1,85 \\
$\mathbf{0}$ & Ago & 0,53 \\
$\mathbf{0}$ & Set & 0,10 \\
$\mathbf{5}$ & Out & 0,20 \\
& Nov & 0,15 \\
& Dez & 0,20 \\
& Jan & 0,85 \\
$\mathbf{2}$ & Fev & 3,04 \\
$\mathbf{0}$ & Mar & 2,73 \\
$\mathbf{0}$ & Abr & 0,74 \\
$\mathbf{6}$ & Mai & 00 \\
& Total & 25,32
\end{tabular}

Embora em maio de 2006 não tenha sido registrada existência de fase livre, não é possível afirmar que esta não volte a ocorrer pois, no gráfico da Figura 30, pode-se perceber que houve uma redução do volume recuperado nos meses de agosto a dezembro de 2005, com um aumento de volume retirado novamente no início de 2006, sem que haja registro de novo vazamento. 


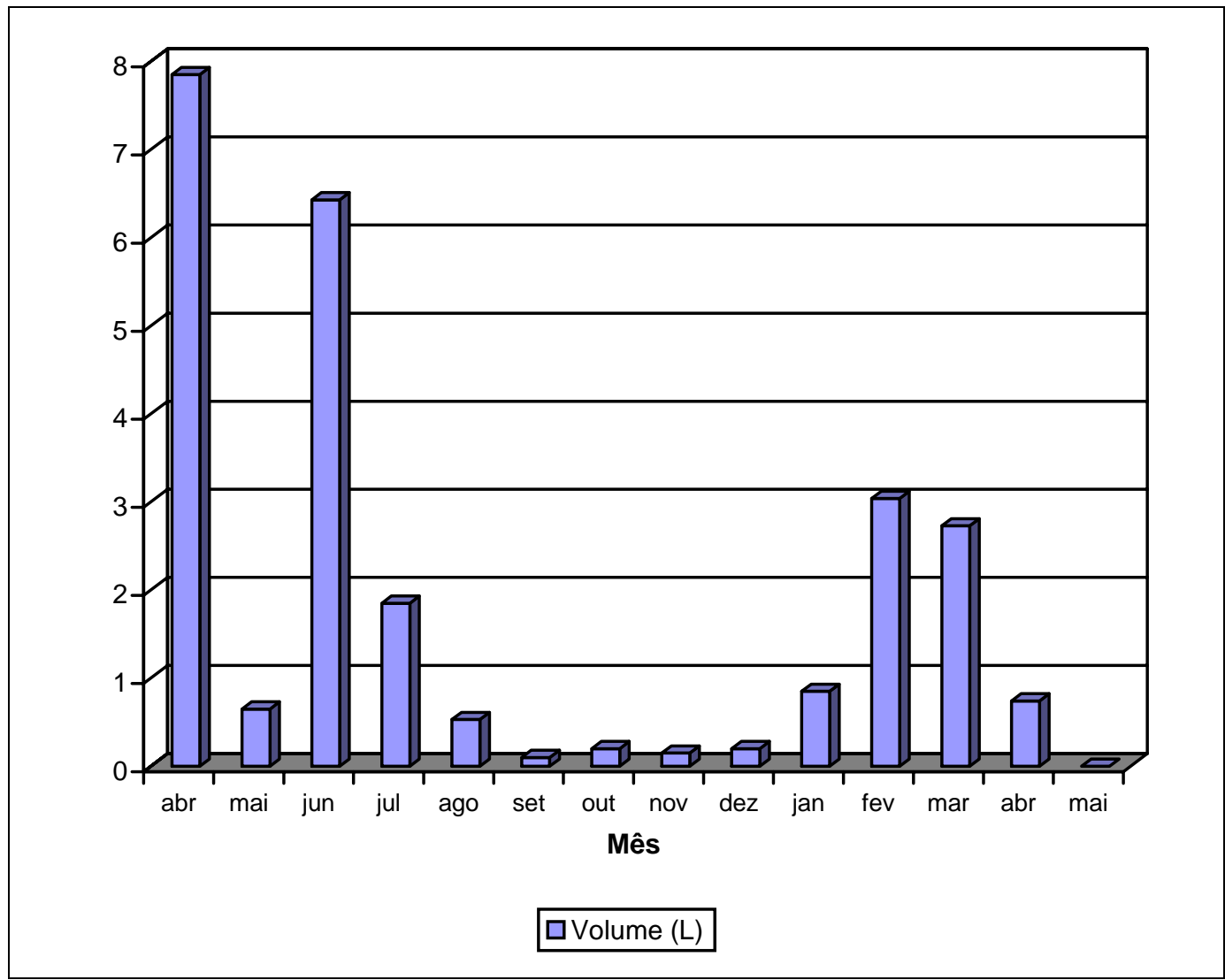

Figura 30 - Caso 2 - Volume de fase livre removida do PM-10

O Caso 2 contou com a contratação de 6 consultorias para análises, para elaboração do projeto para reforma do posto, instalação dos tanques, análises laboratoriais e elaboração do RBCA.

\subsection{CASO 3}

O Caso 3 localiza-se no bairro do Jardim Cumbica, com bandeira SHELL e área de 450,0 $\mathrm{m}^{2}$. Não consta nenhuma reforma no posto apenas com uma mudança de local de bomba e filtro de óleo diesel; sua construção é datada de 1983. A tancagem do posto é composta por 6 tanques de armazenamento subterrâneo de combustíveis, todos com 
capacidade de 15,0 $\mathrm{m}^{3}$, sendo 1 de gasolina comum, 2 de gasolina aditivada, 1 de álcool comum e 1 de álcool aditivado e 1 para diesel comum e um tanque subterrâneo de 5,0 m³ para armazenamento de óleo lubrificante usado. O posto efetua troca de óleo e lavagem de veículos como atividades além da comercialização de combustíveis.

A pavimentação da área de abastecimento e de tancagem é de concreto apresentando trincas visíveis e canteiros. As ruas nos arredores são pavimentadas com asfalto e paralelepípedos, no entanto, as calçadas são concretadas. A água utilizada no empreendimento é fornecida pela concessionária SAAE, entretanto, a água utilizada para fins operacionais é proveniente do poço cacimba.

O entorno do Caso 3 é composto por residências, escola e pequenos comércios, sendo que além do próprio posto, muitos estabelecimentos no entorno utilizam-se de captação de água subterrânea através de poços cacimba para consumo doméstico. Assim, a área de entorno do posto é considerada como Classe 2, segundo a NBR 13.786/01.

A geologia local é representada por material argiloso de cor marrom avermelhada levemente plástico até a profundidade média de 5,0 m, seguido de material argilo-arenoso variado com espessura média de 2,2 m, chegando a grãos grossos de areia em meio a matriz argilosa de cor bege a branca. Quanto à hidrogeologia local, o nível d’água (Na) no aqüífero freático apresenta profundidade de 5,5 m conforme análise da Consultoria E e 7,0 m de profundidade segundo a Consultoria $\mathrm{F}$, mas ambos concordam que o aqüífero presente sob a área estudada é de caráter livre e o fluxo subterrâneo de Leste para Oeste.

Em dezembro de 1998, houve uma reclamação da população vizinha (50,0 m de distância) sobre aparecimento de fase livre nos poços cacimba de um lava-rápido e uma residência. Segundo o proprietário do posto, em outubro 1998, percebeu-se perda de aproximadamente 3,5 $\mathrm{m}^{3}$ de óleo diesel. No entanto, o Caso 3 ainda não havia sido convocado para licenciamento pela Cetesb, portanto ainda não possuia as devidas licenças e não havia assinado o Termo de Ajuste de Conduta - TAC, até junho de 2006. 
Em janeiro de 1999, a Consultoria E concluiu a caracterização da pluma após a realização de 19 sondagens. Deixando no local 5 poços de monitoramento e 4 poços de bombeamento, denominados PB, como pode ser observado na Figura 31.

Segundo o relatório apresentado após as análises do material coletado na sondagem, a Consultoria E informou que havia sido detectada presença de fase livre de óleo diesel em 7 pontos de sondagens (TR-02, TR-03, TR-04, TR-08, TR-09, TR-13 e TR-17). No solo na sondagem TR-06 notou-se presença combustível adsorvido. Nos pontos TR-05, TR-07, TR14 e TR-18, notou-se a existência de gasolina no subsolo.

O mesmo relatório de avaliação da presença de combustíveis no solo e no lençol freático (fevereiro de 1999) informa que não foi encontrada fase livre após a instalação dos poços, porém seria iniciada a remoção da fase livre de óleo, manualmente, no poço raso de abastecimento localizado na residência. O dono do lava-rápido levou algum tempo para permitir a instalação de um skimmer no local. Neste mesmo mês, o posto recebeu um AIIPA Cetesb por não apresentar o plano de remediação e não proceder o bombeamento de fase livre.

A pluma de contaminação de fase livre de óleo diesel sobrenadante ao lençol freático ultrapassa os limites do posto, mas os poços de monitoramento e bombeamento instalados não apresentam fase imiscível de combustível. Assim, o mesmo relatório de avaliação recomenda monitoramento 2 vezes por semana e, desde que a espessura de fase livre não ultrapassasse 5,0 cm, continuasse a remoção por mantas absorventes. Quando o proprietário do lava-rápido permitiu, instalou-se um skimmer automático e em março de 1999 a lâmina de fase livre observada foi removida com manta absorvente. Ainda em maio do mesmo ano, ocorreu visualização de fase livre nos PM-03 e PM-05, que segundo um funcionário, deveu-se a um novo vazamento no filtro de diesel. 


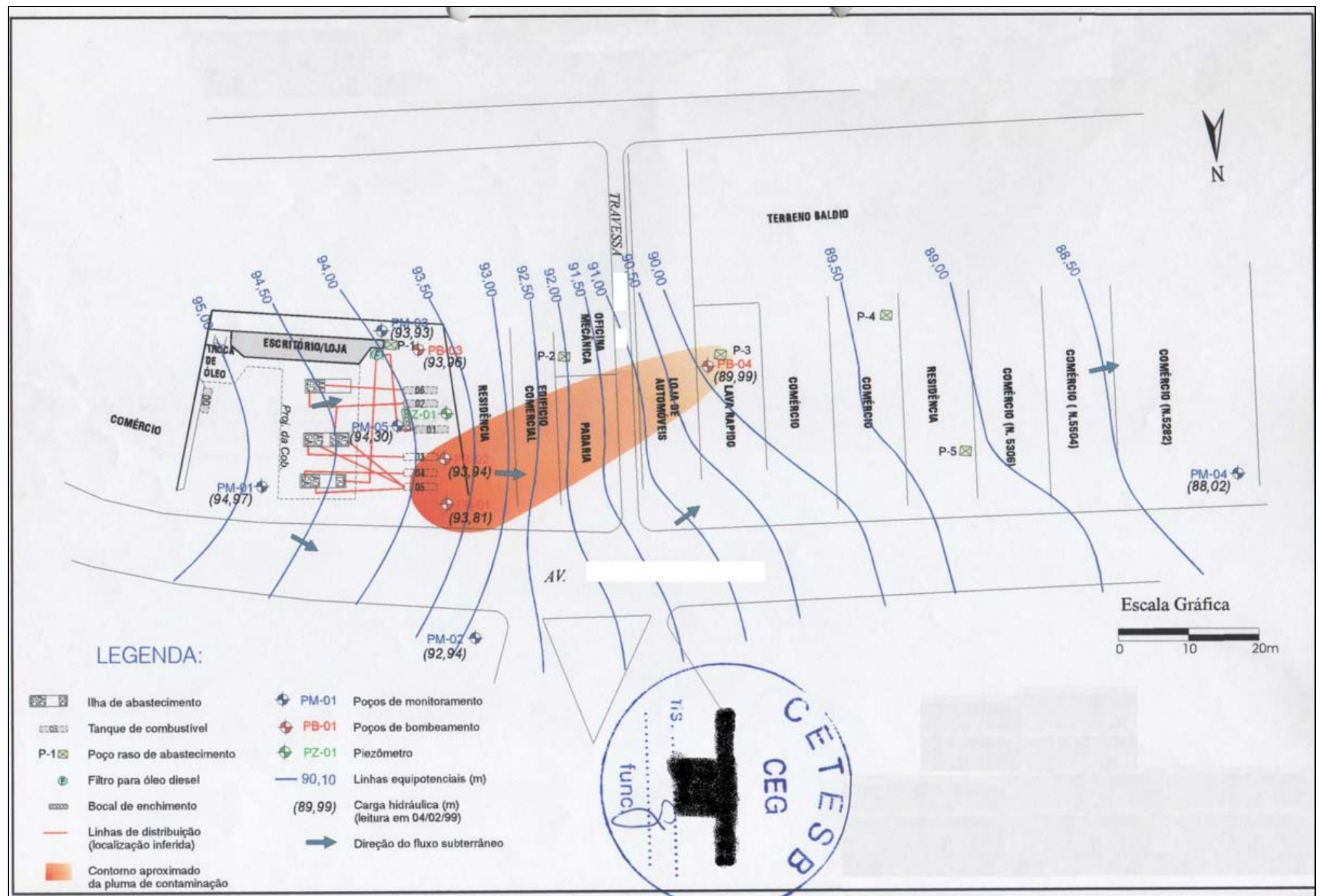

Figura 31 - Caso 3 - Mapa potenciométrico, delimitação da pluma de contaminação e entorno (janeiro de 1999) 
Em agosto de 1999 o posto recebeu um AIIPA da Cetesb por presença de lâmina de 1 a 4 mm de gasolina em fase livre nos poços PB-01, PB-02, PB-03, PM-03 e PM-05. Nesta mesma época, instalou-se bombeamento de fase livre com auto pump no poço cacimba, dirigindo-se para caixa separadora água/óleo e, ao mesmo tempo, skimmer passivo no PM-01. Em monitoramento apresentado em setembro de 1999 a situação manteve-se a mesma. Ainda em novembro, a Consultoria F apresentou o RBCA - Tier 1, o qual classifica o posto como Classe 2 segundo a NBR 13.786, devido a existência de escola e poço de água para consumo doméstico nas proximidades. Neste mesmo relatório concluiu-se que a concentração de benzeno detectada conferia risco à saúde humana.

De março de 1999 a fevereiro de 2000, mensalmente a Consultoria F, apresentou relatórios denominados “Medição da Operação de Saneamento”. Os valores relacionados nestes documentos constam na Tabela 14. Em junho do mesmo ano ocorreu a instalação de skimmer passivo para contínua remoção de fase livre no PB-01 e instalação de auto pump associado a SAO no poço cacimba P-03. Em julho o Caso 3 informou à Cetesb sobre o vazamento de mais $1500 \mathrm{~L}$ de óleo diesel e em agosto o agente credenciado do órgão de controle de poluição do governo do Estado de São Paulo constatou, em inspeção realizada, presença de gasolina nos PB-03, PM-03, PM-05, PB-02 e PB-01 proveniente de novo vazamento.

Tabela 14 - Caso 3 - Volume de combustível recuperado

\begin{tabular}{|c|c|c|}
\hline Ano & Período & Volume (L) \\
\hline \multirow{7}{*}{1999} & de $01 / 03$ a $22 / 04$ & 9,4 \\
\hline & de 23/04 a 19/06 & 48 \\
\hline & de $20 / 06$ a $14 / 07$ & 83 \\
\hline & de $15 / 07$ a $16 / 08$ & 106,0 \\
\hline & de $17 / 08$ a $13 / 09$ & 64,0 \\
\hline & de $14 / 09$ a $14 / 10$ & 73,0 \\
\hline & de $15 / 10$ a $17 / 11$ & 20,0 \\
\hline \multirow{3}{*}{2000} & de $26 / 11$ a 22/12 & 4,5 \\
\hline & de $04 / 01$ a $31 / 01$ & 0,0 \\
\hline & Total & 407,9 \\
\hline
\end{tabular}


Ainda em setembro de 1999, foi detectada presença de fase livre no P-05 e, para remoção, foi instalado no auto pump e outro SAO.

O gráfico da Figura 32 mostra o volume de combustível removido da contaminação existente. Nele, pode-se perceber o aumento de recuperação de fase livre logo após o novo vazamento.

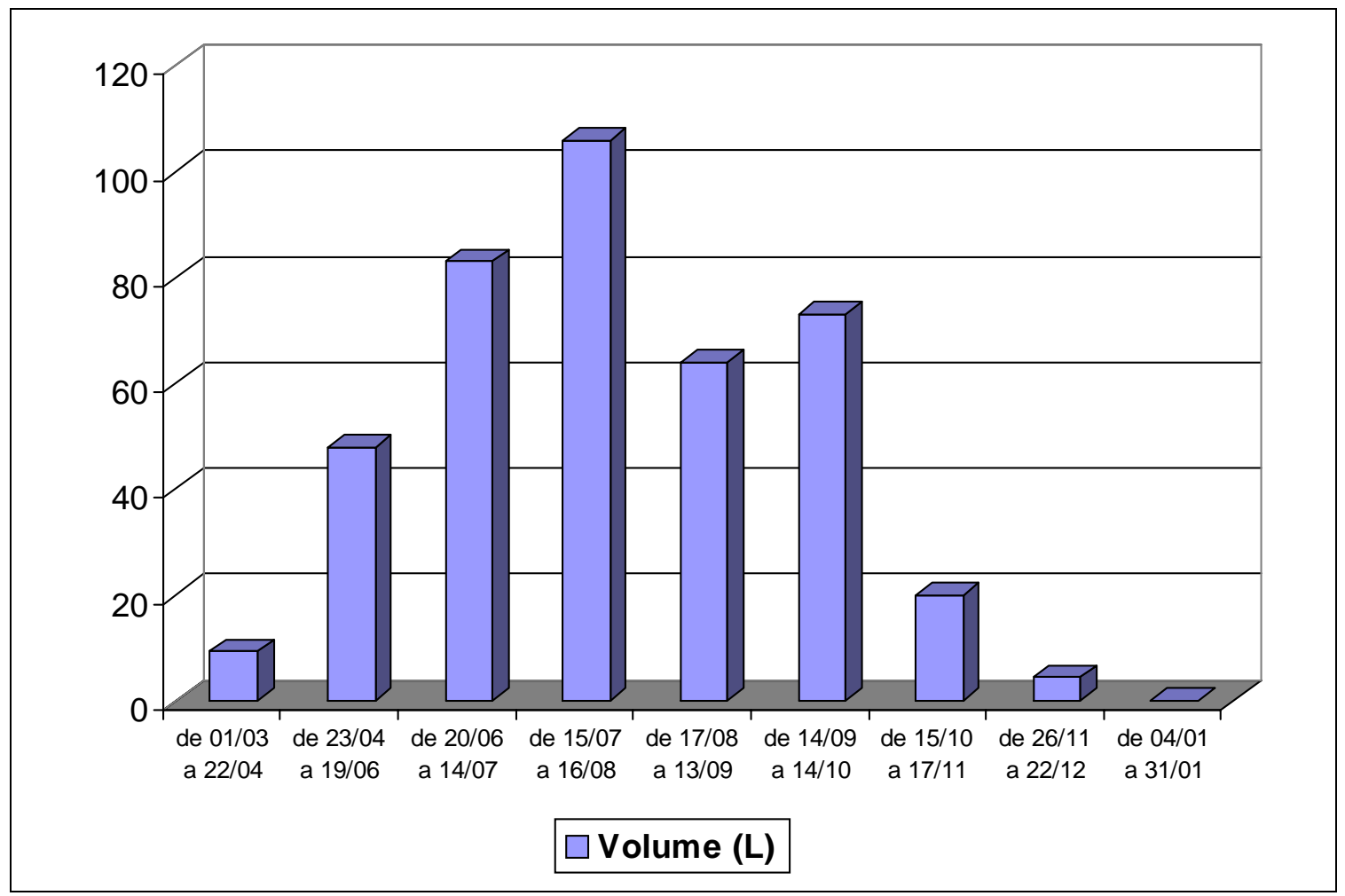

Figura 32 - Caso 3 - Volume de fase livre removida

Em abril de 2000 em virtude de ausência de fase livre por três meses consecutivos, houve a substituição da operação de remoção de fase livre por monitoramento semanal. Em maio do mesmo ano, os proprietários informaram à Cetesb, a paralisação do bombeamento na cacimba do lava-rápido (P-03) por exigência do proprietário e voltou a ser percebida fase livre de diesel nos PM-03, PB-01 e PB-02. Em março de 2001, ocorreu a retomada do bombeamento do P-03 e desativação do sistema implantado na cacimba P-07.

Em abril de 2004 a Consultoria F apresentou Relatório de Investigação Ambiental Complementar, para o Caso 3, no qual as análises laboratoriais das amostras de solo 
indicaram a presença de concentrações detectáveis para parâmetro BTEX no ponto S-03. Bem como para os parâmetros PAH e TPH, porém, os que interessam a este estudo são somente os BTEX. Para água subterrânea dos poços PB-01, PB-02 e PB-03, os valores das concentrações destes compostos também foram detectados, no entanto, todos eles não superam os valores orientadores definidos pela Cetesb (2001). Esta superação só ocorreu para água subterrânea nas amostras dos PM-10, PM-12, PB-01, PB-02, PB-03 e PB-04 para os compostos de benzeno. Para os compostos de tolueno e xileno as amostras dos poços PB-01, PB-02 e PB-03 superaram o valor orientador. Nesta análise, a pluma de fase dissolvida foi delimitada à jusante do empreendimento nos poços PM-09, P-6 e P-7, como mostra a Figura 31. Neste tempo, a pluma de contaminação já foi delimitada alcançando mais 11 terrenos com edificações na vizinhança, conforme Figura 33.

As três sondagens realizadas para este Relatório de Investigação Ambiental Complementar foram executadas a trado obedecendo a Norma para Construção de Poços de Monitoramento e Amostragem - Procedimento (NBR-13.895/97). Durante a coleta não foi visualizada fase livre nas sondagens novas nem nos poços preexistentes. Os resultados analíticos provenientes das amostras de solo encontram-se na Tabela 15.

Tabela 15 - Caso 3 - Análise de solo (abril de 2004)

\begin{tabular}{|c|c|c|c|c|c|}
\hline \multirow[t]{2}{*}{ Parâmetros } & \multirow{2}{*}{$\begin{array}{l}\text { SD-01 } \\
(\mu \mathrm{g} / \mathrm{kg})\end{array}$} & \multirow{2}{*}{$\begin{array}{l}\text { SD-02 } \\
(\mu \mathrm{g} / \mathrm{kg})\end{array}$} & \multirow{2}{*}{$\begin{array}{l}\text { SD-03 } \\
(\mu \mathrm{g} / \mathrm{kg})\end{array}$} & \multicolumn{2}{|c|}{$\begin{array}{c}\text { Padrões de referência } \\
(\mu \mathrm{g} / \mathrm{kg})\end{array}$} \\
\hline & & & & Cetesb & RBSL \\
\hline Benzeno & $<1,00$ & $<1,00$ & 0,01 & 1500,0 & 15,0 \\
\hline Tolueno & $<1,00$ & $<1,00$ & $<1,00$ & 40000,0 & 37000,0 \\
\hline Etilbenzeno & $<1,00$ & $<1,00$ & 0,003 & $\mathrm{Ne}$ & 36000,0 \\
\hline Xilenos totais & $<1,00$ & $<1,00$ & $<1,00$ & 6000,0 & 480000,0 \\
\hline
\end{tabular}

Nas tabelas 16a, 16b e 16c estão listados os resultados analíticos provenientes das amostras de água subterrânea dos poços de monitoramento pré-existentes. 
Tabela 16a - Caso 3 - Análise de água subterrânea (abril de 2004)

\begin{tabular}{|c|c|c|c|c|c|c|c|c|}
\hline \multirow{2}{*}{ Parâmetros } & \multirow{2}{*}{$\begin{array}{l}\text { PM-01 } \\
(\mu \mathrm{g} / \mathrm{L})\end{array}$} & \multirow{2}{*}{$\begin{array}{l}\text { PM-02 } \\
(\mu \mathrm{g} / \mathrm{L})\end{array}$} & \multirow{2}{*}{$\begin{array}{l}\text { PM-05 } \\
(\mu \mathrm{g} / \mathrm{L})\end{array}$} & \multirow{2}{*}{$\begin{array}{l}\text { PM-06 } \\
(\mu \mathrm{g} / \mathrm{L})\end{array}$} & \multirow{2}{*}{$\begin{array}{r}\text { PM-07 } \\
(\mu \mathrm{g} / \mathrm{L})\end{array}$} & \multirow{2}{*}{$\begin{array}{l}\text { PM-8 } \\
(\mu \mathrm{g} / \mathrm{L})\end{array}$} & \multicolumn{2}{|c|}{$\begin{array}{c}\text { Valores de referência } \\
(\mu \mathrm{g} / \mathrm{L})\end{array}$} \\
\hline & & & & & & & $\begin{array}{c}\text { Lista } \\
\text { Holandesa }\end{array}$ & $\begin{array}{l}\text { Cetesb } \\
\text { (2001) }\end{array}$ \\
\hline Benz & $<1,00$ & $<1,00$ & $<1,00$ & $<1,00$ & $<1,00$ & $<1,00$ & 30 & 5 \\
\hline Tolueno & $<1,00$ & $<1,00$ & $<1,00$ & $<1,00$ & $<1,00$ & $<1,00$ & 1.000 & 170 \\
\hline Etilbenzeno & $<1,00$ & $<1,00$ & $<1,00$ & $<1,00$ & $<1,00$ & $<1,00$ & 150 & $\mathrm{Ne}$ \\
\hline Xileno & $<1,00$ & $<1,00$ & $<1,00$ & $<1,00$ & $<1,00$ & $<1,00$ & 70 & 300 \\
\hline
\end{tabular}

Tabela 16b - Caso 3 - Análise de água subterrânea (abril de 2004)

\begin{tabular}{|c|c|c|c|c|c|c|c|c|}
\hline \multirow{2}{*}{ Parâmetros } & \multirow{2}{*}{$\begin{array}{c}\text { PM-09 } \\
(\mu \mathrm{g} / \mathrm{L})\end{array}$} & \multirow{2}{*}{$\begin{array}{c}\text { PM-10 } \\
(\mu \mathrm{g} / \mathrm{L})\end{array}$} & \multirow{2}{*}{$\begin{array}{l}\text { PM-11 } \\
(\mu \mathrm{g} / \mathrm{L})\end{array}$} & \multirow{2}{*}{$\begin{array}{c}\text { PM-12 } \\
(\mu \mathrm{g} / \mathrm{L})\end{array}$} & \multirow{2}{*}{$\begin{array}{l}\text { PB-01 } \\
(\mu \mathrm{g} / \mathrm{L})\end{array}$} & \multirow{2}{*}{$\begin{array}{l}\text { PB-02 } \\
(\mu \mathrm{g} / \mathrm{L})\end{array}$} & \multicolumn{2}{|c|}{$\begin{array}{c}\text { Valores de referência } \\
(\mu \mathrm{g} / \mathrm{L})\end{array}$} \\
\hline & & & & & & & $\begin{array}{c}\text { Lista } \\
\text { Holandesa }\end{array}$ & $\begin{array}{l}\text { Cetesb } \\
(2001)\end{array}$ \\
\hline Benzeno & $<1,00$ & 60,00 & $<1,00$ & 338,00 & 379,00 & 222,00 & 30 & 5 \\
\hline Tolueno & $<1,00$ & 3,00 & $<1,00$ & 10,00 & 997,00 & 574,00 & 1.000 & 170 \\
\hline Etilbenzeno & $<1,00$ & 6,00 & $<1,00$ & 18,00 & 363,00 & 552,00 & 150 & $\mathrm{Ne}$ \\
\hline Xileno & $<1,00$ & $<1,00$ & $<1,00$ & 62,00 & 818,00 & 4151,00 & 70 & 300 \\
\hline
\end{tabular}

Tabela 16c - Caso 3 - Análise de água subterrânea (abril de 2004)

\begin{tabular}{|c|c|c|c|c|c|c|c|}
\hline \multirow{2}{*}{ Parâmetros } & \multirow{2}{*}{$\begin{array}{l}\text { PB-03 } \\
(\mu \mathrm{g} / \mathrm{L})\end{array}$} & \multirow{2}{*}{$\begin{array}{l}\text { PB-04 } \\
(\mu \mathrm{g} / \mathrm{L})\end{array}$} & \multirow{2}{*}{$\begin{array}{c}\text { P-01 } \\
(\mu \mathrm{g} / \mathrm{L})\end{array}$} & \multirow{2}{*}{$\begin{array}{c}\text { P-06 } \\
(\mu \mathrm{g} / \mathrm{L})\end{array}$} & \multirow{2}{*}{$\begin{array}{c}\text { P-07 } \\
(\mu \mathrm{g} / \mathrm{L})\end{array}$} & \multicolumn{2}{|c|}{$\begin{array}{c}\text { Valores de referência } \\
(\mu \mathrm{g} / \mathrm{L})\end{array}$} \\
\hline & & & & & & $\begin{array}{c}\text { Lista } \\
\text { Holandesa }\end{array}$ & $\begin{array}{l}\text { Cetesb } \\
(2001)\end{array}$ \\
\hline Ben & 678,00 & 37,00 & 100 & 00 & 00 & 30 & 5 \\
\hline Tolueno & 816,00 & $<1,00$ & $<1,00$ & $<1,00$ & $<1,00$ & 1.000 & 170 \\
\hline Etilbenzeno & 77,00 & $<1,00$ & $<1,00$ & $<1,00$ & $<1,00$ & 150 & $\mathrm{Ne}$ \\
\hline Xileno & 380,00 & 1,00 & $<1,00$ & $<1,00$ & $<1,00$ & 70 & 300 \\
\hline
\end{tabular}

Em maio de 2004, a Consultoria F apresentou RBCA - Tier 2, para o Caso 3, no qual foram assumidos os parâmetros de exposição para cada receptor, baseados em dados dos Estados Unidos da América e seguem padrões da norma ASTM-1739-95. Segundo RBCA, as concentrações obtidas nas amostras de solo encontram-se abaixo dos Níveis Alvo Específicos 


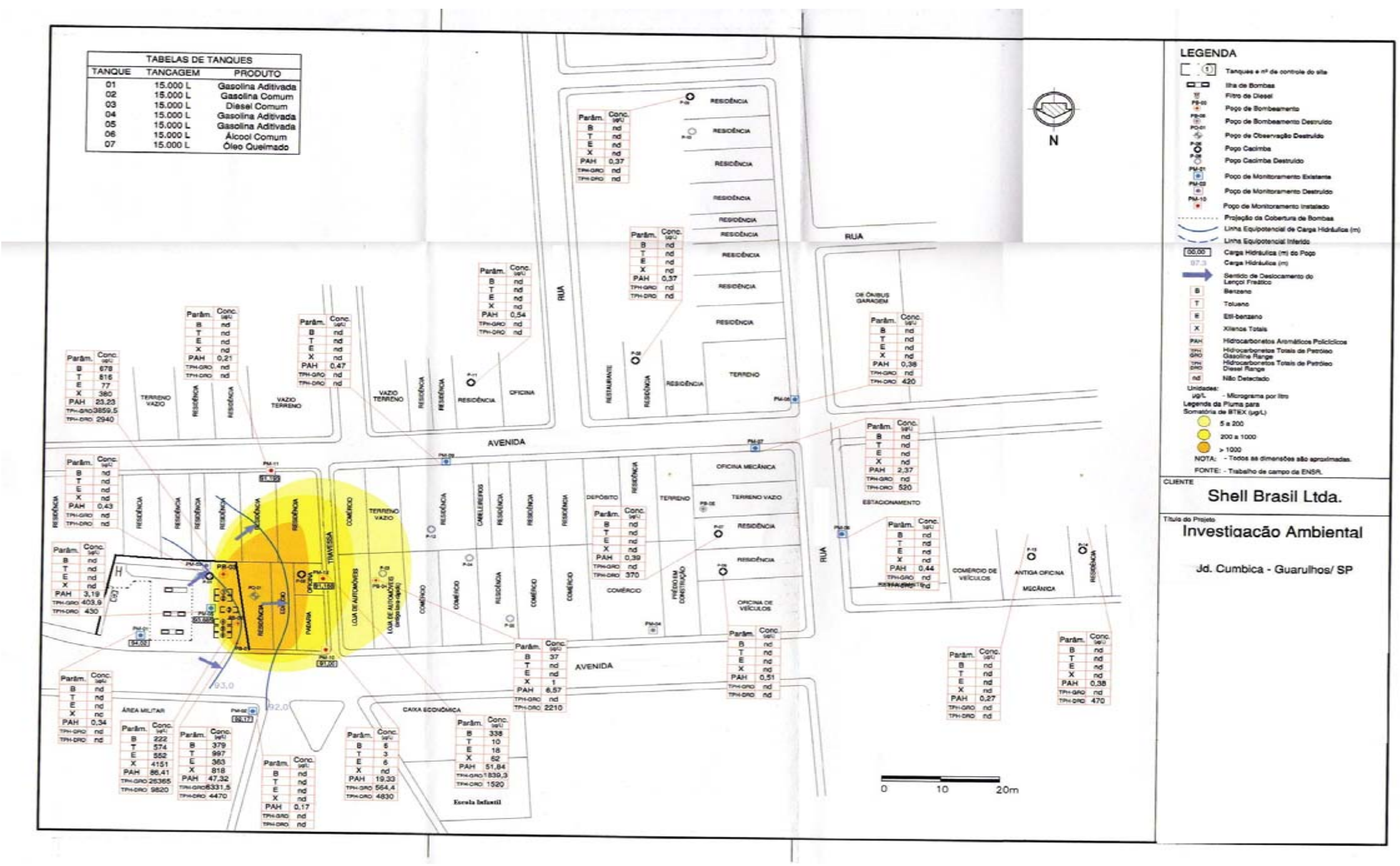

Figura 33 - Caso 3 - Mapa potenciométrico, delimitação da pluma de contaminação e entorno 
da Área, indicando que o solo, nos pontos analisados, não apresenta risco à saúde humana através das vias de exposição consideradas e de acordo com os critérios de risco adotados.

Quanto à água subterrânea, as concentrações obtidas nos poços PM-10, PM-12, PB01, PB-02, PB-03 e PB-04 apresentam risco quando comparados ao SSTL calculado para a via de ingestão de água subterrânea, entretanto estes pontos não são utilizados para captação de água para consumo. Já as análises químicas dos poços utilizados para consumo humano, P-1,P-06, P-07, P-08, P-09, P-11, P-13 e P-14, não apresentaram risco para a via de ingestão de água. Vale ressaltar, que conforme se pode observar nas tabelas 16a, 16b e 16c, estes valores também ultrapassam os valores de referência estipulados pela Cetesb (2001) e alteram a delimitação da pluma de contaminação demarcada nas análises de 1999 (Figura 31), que estendia-se além dos limites do posto, alcançando 6 imóveis vizinhos.

Em janeiro de 2005, o estabelecimento recebeu um Auto de Infração - Imposição de Penalidade de Multa (AIIPM) da Cetesb por falta de monitoramento. Em junho do mesmo ano, recebeu mais AIIPA, seguido de AIIPM (agosto) por ausência de apresentação do plano de remediação e monitoramento.

Em março de 2006, em relatório apresentado pela Consultoria F, não houve visualização de fase livre. Nas amostras de água subterrânea verificou-se também um moderado decaimento nas concentrações de BTEX em relação às verificações anteriores, conforme Tabelas 17, no entanto, as concentrações ainda estão acima dos SSTL's. 
Desta análise, pode-se delimitar a pluma de contaminação ainda a jusante do empreendimento, (Figura 33) nos poços PM-06, P6 e P7. E quanto às águas subterrâneas, as amostras retiradas dos poços PM-10, PM-12 e PB-01, PB-02, PB-03 e PB-04 apresentam risco no caso de consumo e ingestão destas. Vale salientar que o poço cacimba corresponde a um poço raso que capta as águas do aqüífero freático local. Logo, quando compara-se os valores de benzeno das amostras dos PM's e PB's, observa-se que estes ultrapassam o padrão de potabilidade da Portaria n $^{\circ} 518$ e, no caso de PM-21, excede o NABR referente ao contato dermal com a água subterrânea por receptores comerciais. Portanto, tais concentrações representam risco potencial para os trabalhadores do posto que utilizam as águas do referido poço.

A Cetesb recebeu em maio de 2003, maio de 2005 e fevereiro de 2006, ofícios do Ministério Público questionando sobre a contaminação do Caso 3. Todos foram respondidos informando a situação em cada uma das datas.

O Caso 3 utilizou-se do trabalho de 5 empresas entre consultorias e laboratórios de análises para remediação da contaminação existente e até junho de 2006 ainda não havia apresentado plano de remediação.

\subsection{CASO 4}

O Caso 4 encontra-se instalado no bairro de Bonsucesso, com área de terreno de 19.000,0 m². Na documentação apresentada à agência ambiental não existe registro de como estava a tancagem anterior, no entanto, a tancagem atual é composta, desde julho de 1997, de 5 tanques para diesel aditivado com 30,0 $\mathrm{m}^{3}$ de capacidade, 2 tanques de 30,0 $\mathrm{m}^{3}$ com diesel comum, 1 tanque de 15,0 $\mathrm{m}^{3}$ com gasolina aditivada, 1 tanque de 30,0 $\mathrm{m}^{3}$ com gasolina 
comum e 1 tanque de 30,0 m³ com álcool comum. A pavimentação da área de tancagem é em concreto porém as demais áreas são em paralelepípedo. Possui abastecimento de água por rede pública (SAAE) e a galeria de esgoto via caixa separadora água e óleo (CSAO). No entanto, o posto possui um poço cacimba e suas águas, segundo os funcionários, são utilizadas na lavagem dos vidros dos veículos que passam pelo posto, abastecimento dos radiadores dos carros e para lavagem de mãos dos passantes e frentistas do posto.

Além do armazenamento e comércio de combustíveis, o estabelecimento conta ainda com lubrificação, borracharia, auto-elétrico, loja de auto-peças, estacionamento, troca de óleo, bar-lanchonete e restaurante.

O entorno é composto por indústrias, galpões industriais e garagens de transportadoras. As residências mais próximas estão localizadas a cerca de 500,0 m do posto. Segundo informações do Departamento de Águas e Energia Elétrica (DAEE), num raio de 3,5 km da área do posto existem 12 poços cadastrados sendo 9 profundos (com aproximadamente 178,0 m) e 3 rasos (com 12 m). As águas destes poços são destinadas ao uso doméstico e industrial. Portanto segundo a ABNT/NBR 13.786/2001, o posto é Classe 1, inclusive pela existência de rede subterrânea de serviços (água, esgoto, telefone, energia elétrica) e de um poço de abastecimento (PC-01) sob ameaça imediata. Durante a medição do nível d'água nos poços existentes foi constatada película no PB-02. Os poços PM-10, PM-14 e PM-17 estavam secos durante a medição.

O Caso 4 recebeu um AIIPA em dezembro de 1994 por apresentar vazamentos detectados em uma caixa de inspeção da companhia de telefonia, por funcionários desta companhia.

Em 1995 perceberam-se dois vazamentos de combustíveis: o primeiro no tanque $n^{\circ} 06$ e o segundo na linha de distribuição. Diante desta situação providenciou-se uma avaliação através da qual constatou-se presença de combustíveis no solo, lençol freático e presença de combustível em fase livre em uma caixa de inspeção da TELESP. A partir destas 
constatações, houve o início da operação de saneamento do lençol freático através do bombeamento alternado dos poços de monitoramento PM-03 e PM-06,com tratamento e reinfiltração das águas subterrâneas. Ainda neste ano, por início das investigações adicionais do solo/lençol freático e operação do sistema de saneamento, constatou-se um novo vazamento na linha de distribuição. Assim, realizaram-se as investigações adicionais e instalação de novo poço de monitoramento na área do Caso 4. Através das investigações, concluiu-se que a pluma de contaminação referente a este novo vazamento ficou restrita à área do posto. E em dezembro de 1995 o Caso 4 foi multado pela Cetesb, por conta destes vazamentos.

Em 1996 em investigações adicionais, foi detectado mais um vazamento a partir do filtro de óleo diesel, no qual foram instalados 03 poços de bombeamento, 01 de monitoramento e 01 de infiltração (localizados na Figura 34), motivo pelo qual recebeu novo AIIPM da Cetesb em março e setembro. Nesta época, a delimitação da pluma de fase livre de óleo diesel restringiu-se a porção central do posto, com aproximadamente $6.500 \mathrm{~m}^{2}$, englobando a área de tancagem, parte da área das bombas de abastecimento e do filtro de diesel. A partir destas investigações adicionais, ocorreu a elaboração do plano de bombeamento.

Em 1997 houve uma reforma no Caso 4 na qual foram trocados os tanques de estocagem. No ano seguinte, através de avaliação ambiental do solo e águas subterrâneas e análise de risco - serviço este, executado de forma a atender às solicitações da Cetesb obtiveram-se resultados que indicaram presença de fase livre com espessura não superior a 2 cm, porém as concentrações de benzeno superaram o SSTL calculado para o caminho de inalação de vapores provenientes do solo e da água subterrânea em ambientes internos para os trabalhadores administrativos. 


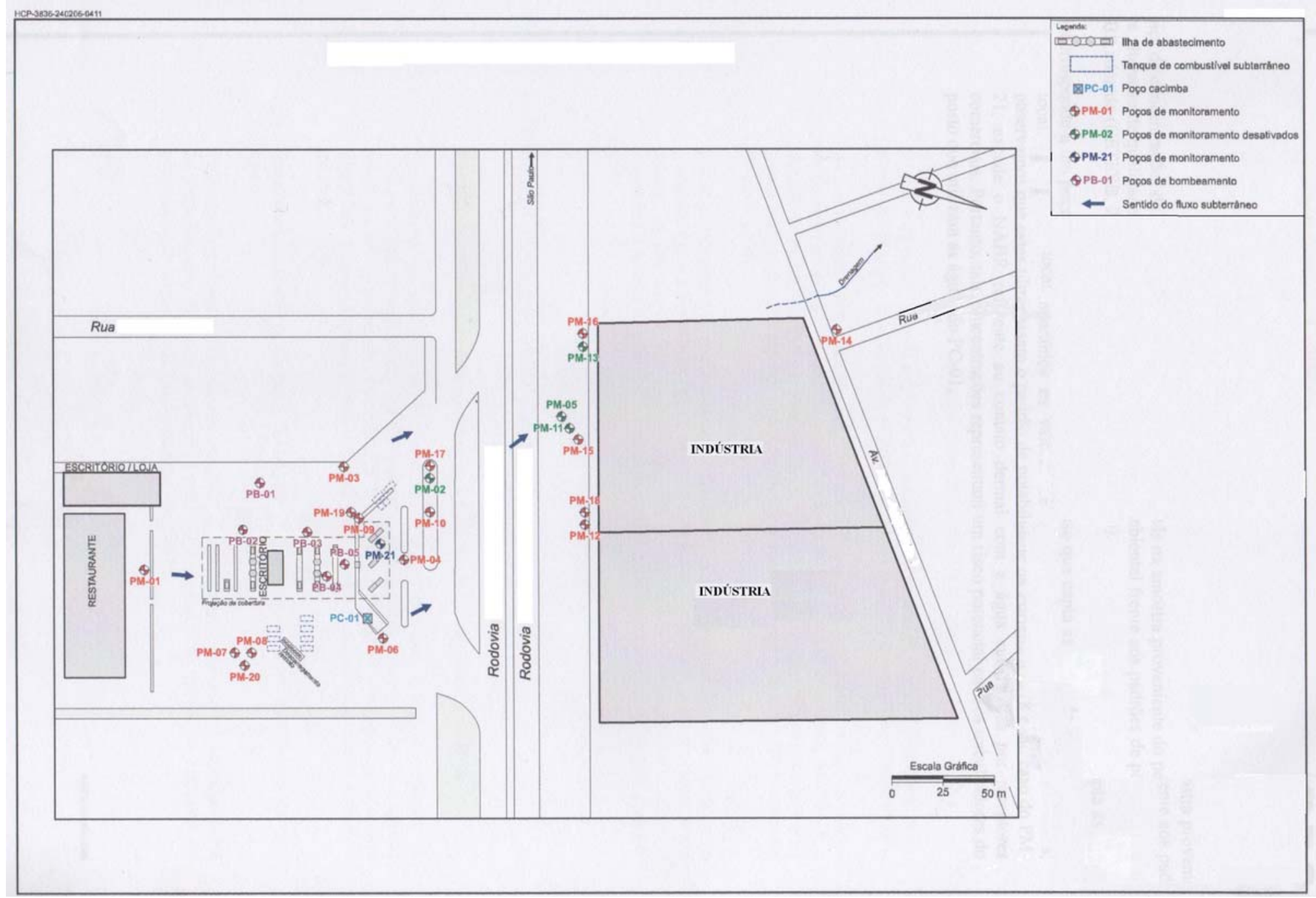

Figura 34 - Caso 4 - Mapa potenciométrico e instalação dos poços de monitoramento 
O estabelecimento foi mais uma vez multado pela Cetesb em janeiro de 1998 por apresentar novo vazamento.

De 2000 a 2001 foram realizadas amostragens durante um ciclo hidrológico (jun. 2000 a jun. 2001), que resultaram em 04 campanhas de monitoramento analítico das águas subterrâneas. A comparação entre as campanhas realizadas indicou que as concentrações dos contaminantes não sofreram variações relevantes, embora o SSTL comparado relacionado ao benzeno tenha sido ultrapassado em todas as campanhas, em pelo menos uma amostra.

Em 2001 foi efetuado monitoramento de vapores orgânicos in door, que durou 1 ano. Nele foram efetuadas 06 campanhas de amostragem por empresa terceirizada, conforme plano de monitoramento de vapores. Os resultados mostraram que as concentrações de BTXE detectadas encontravam-se abaixo do SSTL mais restritivo. Ainda no mesmo ano foi efetuada uma reforma parcial do piso do posto onde houve troca das placas de concreto que apresentavam rachaduras. Conforme carta do empreendimento constante no processo de licenciamento (mar. 2004) houve instalação de mais um tanque identificado como nº 09.

Em julho de 2002, foi apresentado à Cetesb o laudo de estanqueidade de todos os tanques. E em 2003, junto com a solicitação de Licença de Operação, foi apresentado um memorial descritivo para adequação do posto às condições mínimas de reforma. Ainda em 2003 constatou-se, por monitoramento analítico das águas subterrâneas, a ocorrência de pluma de fase livre de óleo diesel abrangendo uma área estimada de 1600 m². Porém, as concentrações dissolvidas dos compostos detectados eram inferiores ao SSTL de inalação de vapores provenientes da água subterrânea em ambientes internos para os trabalhadores administrativos.

Em correspondência datada de março de 2004, a Consultoria E afirma que a região onde está instalado o empreendimento não é provida de rede pública de coleta de esgotos e o posto adotaria reservatório específico para efluentes que se encontrava em projeto.

Em junho de 2005 o Caso 4 assinou o TAC junto à Cetesb e em julho do mesmo ano 
foram realizadas análises, com 4 amostras de solo e 15 amostras de água subterrânea para verificação de BTEX, TPH (GRO e DRO) e PAH. As águas do poço cacimba foram avaliadas frente aos padrões de potabilidade da Portaria $n^{\circ} 518$ do Ministério da saúde (2004) e aos NABR's referentes ao contato dermal (LOPES et al., 2001). Cabe ressaltar que o PC-01 corresponde a um poço raso que capta as águas do aqüífero freático local. Dessa forma, comparando-se os resultados analíticos dos PM's e PB's aos padrões, verifica-se que, de modo geral, as concentrações de benzeno detectadas no centro de massa da pluma excedem aos padrões de potabilidade da Portaria ${ }^{\circ} 518$ e no caso do PB-03 também ultrapassa o NABR para contato dermal com a água por receptores comerciais. Portanto, o posto foi avisado pela consultoria que a continuidade da utilização das águas do PC-01, acarretaria grande risco potencial aos trabalhadores do posto e outros que venham a utilizar esta água, mesmo que os valores obtidos nas análises destas não tenham ultrapassado os limites admissíveis. A Tabela 18 contém os resultados das concentrações de BTEX nas análises efetuadas nas amostras de água coletadas no PC-01 do Caso 4 em julho e dezembro de 2005.

Tabela 18 - Caso 4 - Análises de água subterrânea (mg/L) - 2005

\begin{tabular}{ccccc}
\hline Mês & Benzeno & Tolueno & Etilbenzeno & Xilenos \\
\hline Julho & 0,001 & n.d. & n.d. & n.d. \\
Dezembro & 0,001 & n.d. & n.d. & n.d. \\
Portaria n ${ }^{\circ} \mathbf{5 1 8}$ & 0,005 & 0,17 & 0,2 & 0,3 \\
n.d. - não detectável & & &
\end{tabular}

Na sondagem S-05, foi observada a presença de $0,5 \mathrm{~cm}$ de fase livre de produto e o $\mathrm{Na}$ (nível d’água) a 3,0 m. Já nas sondagens S-01, S-03 e S-04 não foram verificados indícios táctil-visuais da presença de produto. Apenas a S-03 apresentou traços de tolueno e xilenos, nas demais, não foram detectados compostos BTEX, mesmo nas que foram verificados fase livre. Foi detectado PAH somente no S-03 e S-05 (apresentou apenas 2-metilnaftaleno), que não são objeto deste estudo. De acordo com as análises acima citadas, as concentrações de BTEX e PAH detectadas nas amostras de solo dos locais investigados na atual campanha são 
inferiores aos SSTL's mais restritivos aplicáveis ao local, referentes à inalação de vapores orgânicos em ambientes fechados por receptores comerciais. A Tabela 19 contém os resultados das concentrações de BTEX nas análises efetuadas em amostras de solo coletadas no Caso 4 em julho de 2005.

Tabela 19 - Caso 4 - Análises de solo (mg/kg) - 2005

\begin{tabular}{ccccc}
\hline Sondagem & Benzeno & Tolueno & Etilbenzeno & Xilenos \\
\hline S-02 & n.d. & n.d. & n.d. & n.d. \\
S-03 & n.d. & 0,017 & n.d. & 0,008 \\
S-04 & n.d. & n.d. & n.d. & n.d. \\
S-05 & n.d. & n.d. & n.d. & n.d. \\
SSTL $^{1}$ & 0,52 & 67 & 260 & $>500$ \\
SSTL $^{2}$ & 4,4 & 410 & $>630$ & $>500$ \\
SSTL $^{3}$ & 27 & $>750$ & $>630$ & $>500$ \\
SSTL $^{4}$ & 34 & $>750$ & $>630$ & $>500$ \\
SSTL $^{5}$ & 67 & $>750$ & $>630$ & $>500$
\end{tabular}

SSTL - Concentração máxima permitida no solo, calculada pela Análise de Risco RBCA Tier 2;

1 - SSTL relacionado à inalação de vapores orgânicos provenientes do solo em ambientes fechados por receptores comerciais;

2 - SSTL relacionado à inalação de vapores orgânicos e particulados provenientes do solo em ambientes abertos por trabalhadores de eventuais obras;

3 - SSTL relacionado à inalação de vapores orgânicos provenientes do solo em ambientes abertos por receptores residenciais vizinhos off site $(50 \mathrm{~m})$;

4- SSTL relacionado à inalação de vapores orgânicos provenientes do solo em ambientes abertos por trabalhadores comerciais on site;

5 - SSTL relacionado à inalação de vapores orgânicos provenientes do solo em ambientes abertos por receptores residenciais vizinhos off site $(100 \mathrm{~m})$.

Embora não seja objeto deste estudo, é importante citar que com relação aos resultados da campanha anterior (janeiro de 2003) nota-se uma diminuição nos valores de TPH GRO nos poços PM-01 e PM-15 e de TPH DRO nos poços PM-03 e PM-18. Por outro lado verifica-se um aumento nas concentrações de TPH DRO nos poços PM-06 e PM-15. De acordo com RBCA Tier 2, as concentrações dissolvidas de BTEX e PAH, atualmente detectadas nas amostras de água subterrânea, estão abaixo dos SSTLs mais restritivos aplicáveis ao caso, referente à inalação de vapores orgânicos em ambientes fechados por receptores comerciais.

Nestas análises realizadas em julho de 2005, concluiu-se que: 
a) embora a maioria dos locais investigados através da execução de sondagens (área de abastecimento e entorno imediato) tenha apresentado produto no solo e/ou película de fase livre de coloração escura, somente a amostra de solo localizada entre as ilhas de abastecimento apresentou concentrações de BTEX e PAH.

b) a pluma de fase dissolvida ocupava a maior parte da área do posto e se estendia até o PM-15, localizado no outro lado da rodovia em que está o estabelecimento. O centro de massa da pluma encontrava-se na área de abastecimento e entorno imediato, onde predominam as concentrações de BTEX E TPH, além de traços de PAH;

c) embora o poço PC-01 não tivesse apresentado alterações de qualidade frente à Portaria $n^{\circ} 518$ para os parâmetros BTEX, a pluma de fase dissolvida representa uma ameaça ao referido poço, uma vez que este capta água do aqüífero freático, que por sua vez apresentou concentrações superiores aos padrões adotados para consumo e contato dermal;

d) as concentrações de BTEX e PAH detectadas nas amostras de solo e água subterrânea não representavam situação de risco à exposição humana para as vias e receptores considerados, desde que não haja aproveitamento das águas do aqüífero freático local para consumo ou qualquer outro fim.

Com base no exposto a Consultoria E recomendou:

a) instalação de 1 PM adicional entre os PM-04 e PM-09;

b) monitoramento quinzenal do nível d'água dos PM’s e PB’s, com o objetivo de identificar a eventual presença de fase livre de produto e, caso necessário, proceder a sua remoção;

c) monitoramento analítico trimestral das águas subterrâneas para os parâmetros BTEX e PAH, durante 1 ano hidrológico completo, com o intuito de avaliar o comportamento da pluma de fase dissolvida ao longo do tempo; 
d) como medida preventiva, a desativação do poço PC-01, de forma a evitar a eventual ingestão das águas subterrâneas impactadas e/ou o contato dermal por parte dos trabalhadores do posto.

Em dezembro de 2005 foram realizadas novas coletas para análise. Durante a operação, foi observada a presença de fase livre de diesel no PB-02, PB-03 e PB-05, todos situados na pista de abastecimento. Nos poços 02 e 05, o produto apresenta coloração escura e as espessuras observadas atingem 5,0 e 3,0 cm respectivamente. No PB-03, a fase livre apresenta coloração clara e espessura de $0,3 \mathrm{~cm}$. Nesta coleta, foram detectadas concentrações de BTEX e PAH apenas nos poços instalados na pista de abastecimento PB-02, PB-03, PB-04 e PB-05, e entorno imediato PB-01 e PM-04, PM-19 e PM-21, caracterizando uma pluma de fase dissolvida com forma alongada e direção Norte/Sul, como pode ser observado na Figura 35. Com a análise das amostras, foi constatado que os maiores valores foram encontrados na atual área de tancagem.

Quanto às concentrações dissolvidas de BTEX e PAH detectadas nas amostras de água subterrânea da campanha realizada em dezembro de 2005, encontram-se abaixo dos SSTL's mais restritivos aplicáveis ao local, referentes à inalação de vapores em ambientes fechados por receptores comerciais. Não foi constatada a presença de concentrações de contaminantes na amostra proveniente do poço PC-01, portanto, este não apresenta alteração de qualidade ambiental frente aos padrões de potabilidade da Portaria n ${ }^{\circ} 518$ e ao NABR adotado (LOPES et al., 2001). 


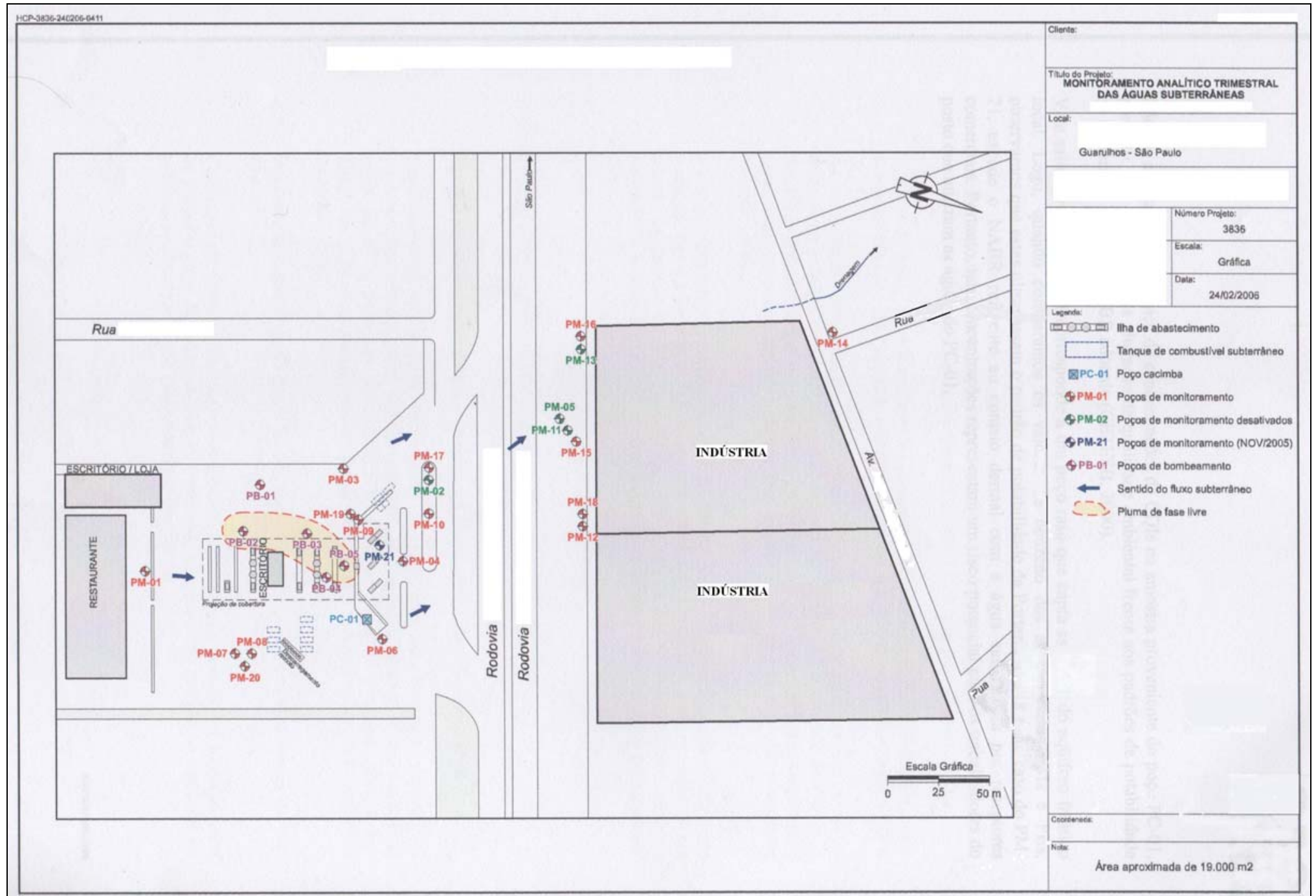

Figura 35 - Caso 4 - Delimitação da pluma de contaminação (dezembro de 2005) 
Ainda com relação ao relatório apresentado referente às coletas de dezembro de 2005 para o Caso 4, a pluma de fase livre conta com aproximadamente $1500 \mathrm{~m}^{2}$ de dimensão, com espessura máxima aparente de $3 \mathrm{~cm}$ nos poços 03 e 05 (Figura 33). As concentrações detectadas são inferiores aos SSTL’s aplicáveis ao local. Contudo, os valores de benzeno excedem o padrão de potabilidade da Portaria $n^{\circ} 518$ e, no caso do PM-21, o NABR de contato dermal por receptores comerciais. O que caracteriza um risco potencial para o aproveitamento das águas do aqüífero freático local, seja para consumo humano ou serviços gerais. Por estes motivos, a consultoria voltou a recomendar a eliminação da fonte primária que dá origem à fase livre; implantação de sistema de remoção de fase livre; desativação preventiva do PC-01 e cuidados no caso de obras que incluam escavações na área do posto.

Em janeiro de 2006 iniciou-se o monitoramento e remoção de fase livre através de bomba diafragma, amostrador de acrílico e interfase meter. A bomba diafragma trabalhou em sistema de rodízio nos poços que apresentaram o produto em fase livre. No mesmo ano, por monitoramento, constatou-se cerca de $47 \mathrm{~cm}$ de fase livre de diesel claro no PB-03, recomendou-se a instalação de uma bomba de diafragma para operar em sistema de rodízio entre os poços que apresentassem fase livre de produto, com acompanhamento diário através do auxílio de um operador. Em março do mesmo ano, em inspeção realizada, constatou-se ocorrência de novo vazamento na tubulação de diesel. Porém já havia uma bomba com caixa separadora para retirada da fase livre no PB-03 e o PC-01 continuava em operação. Toda esta situação repetitiva, bem como a continuidade de utilização das águas do PC-01, demonstraram que estão sendo tomadas apenas medidas paliativas ao contrário do que é necessário por parte dos proprietários. É preciso que seja detectada a fonte de contaminação e seja removida imediatamente, seguida de novo estudo de análise de risco.

No processo de licenciamento constante na Cetesb, só é possível verificar o volume recuperado no ano de 2006, informado pela Consultoria E, conforme Tabela 20 e o gráfico da Figura 36. 
Tabela 20 - Caso 4 - Volume de combustível recuperado

\begin{tabular}{cc}
\hline Período & Volume (L) \\
\hline de 19/12/05 a 31/01/06 & 28 \\
De 01/02 a 28/02 & 74 \\
De 01/03 a 31/03 & 831 \\
De 01/04 a 24/04 & 196 \\
Total & 1129
\end{tabular}

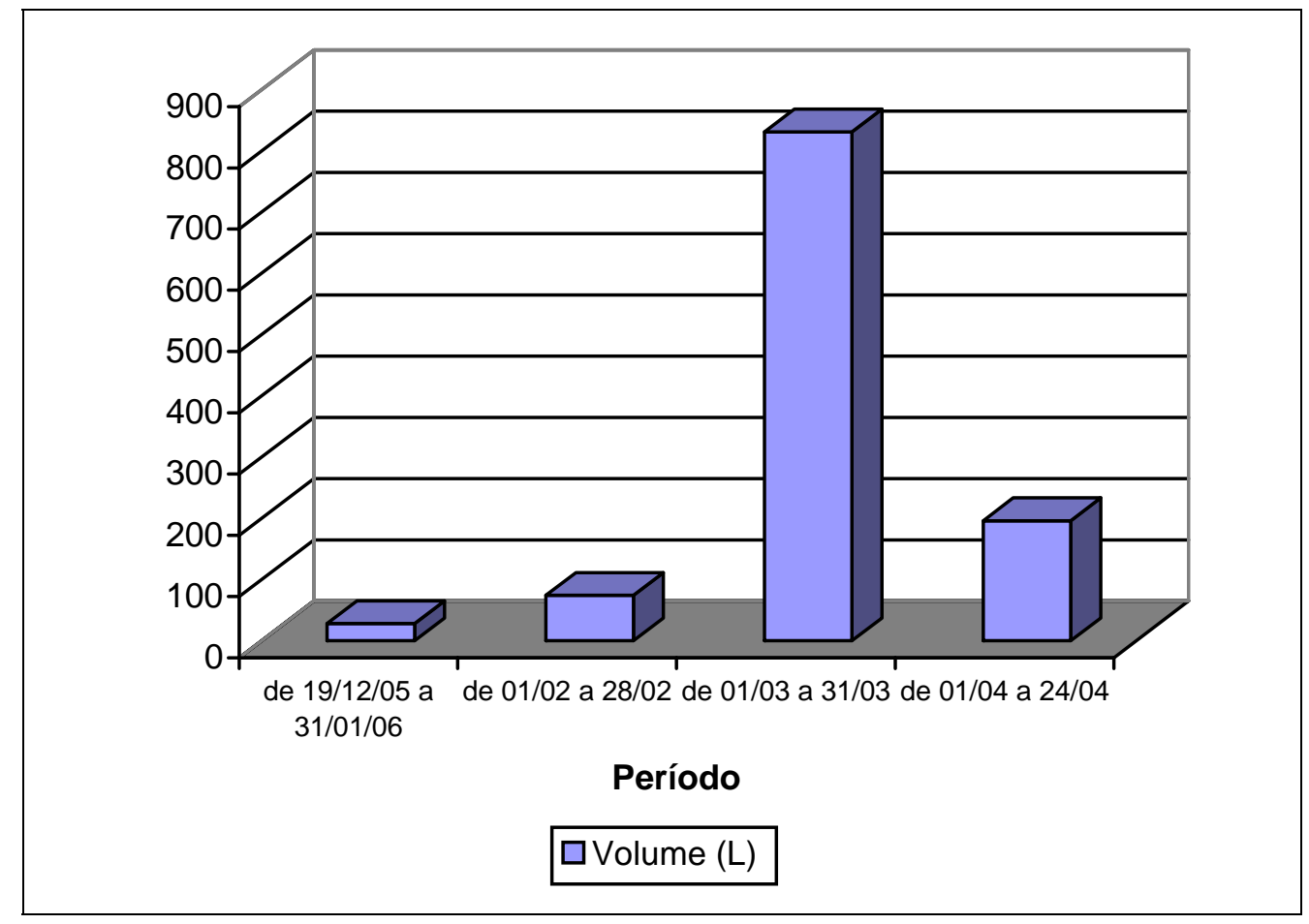

Figura 36 - Caso 4 - Volume de fase livre removida

O empreendimento em questão obteve Licença de Operação em março de 2006 válida até 14/03/11, conforme legislação vigente.

O Caso 4 contou com a contratação de 3 consultorias entre profissionais liberais e empresas contratadas, mas também não apresentou proposta de remediação além de remoção de fase livre. 


\subsection{CASO 5}

O Caso 5 localiza-se na Vila Galvão, com área de aproximadamente 180,0 m². O posto opera desde 1978 sob a bandeira ESSO. São realizadas no posto as atividades de abastecimento, troca de óleo de motor, lavagem de automóveis e loja de conveniência. A ocupação do solo mostra que a região é comercial e residencial, com a existência de água e esgoto encanados, sistema de drenagem de águas pluviais e canalização de rede telefônica, além de existirem prédios com garagens subterrâneas. Conforme investigação no DAEE não existem poços para captação de água subterrânea em um raio de 200 m.

A tancagem do posto era composta por 6 tanques antes da reforma realizada em dezembro de 1999, sendo: 2 de gasolina aditivada, 1 de gasolina comum, 1 de álcool comum, 1 de álcool aditivado, 1 de diesel comum, cada um deles com capacidade de 15,0 $\mathrm{m}^{3}$ (Figura 37). Todos os tanques possuíam descarga direta e controle de estocagem por sistema eletrônico e foram instalados em 1982, segundo o proprietário do posto.

O posto em questão foi alvo de reclamação da população em setembro de 1996 por percepção de odor na pia de estacionamento comercial vizinho. Por este motivo, em outubro do mesmo ano, o tanque $\mathrm{n}^{\circ} 3$ foi esvaziado e desativado e foram instalados 4 poços de monitoramento no posto. Durante a instalação dos poços de monitoramento, foi notado odor de combustível nas sondagens próximas aos tanques, porém não houve ocorrência de fase livre. No primeiro croqui de localização, apresentado pela Consultoria D, o posto está localizado incorretamente.

Quanto à geologia local as sondagens realizadas na área de estudo permitiram identificar do topo para a base, até a profundidade de 10,0 m, as seguintes litologias distintas: o pacote superior é formado por um aterro argilo-arenoso, marrom, com espessura variável; 
argila arenosa multicolor, com espessura média de 5 m;

camada constituída por argila amarela a variegada, compacta, com espessura variável;

$>$ argila, associada com lentes decimétricas de cascalho fino, de extensão lateral restrita e espessura indeterminada;

> argila arenosa, associada com cascalho fino a médio, espessura indeterminada; areia fina a média, variegada, com lentes de cascalho;

a unidade basal é constituída por areia mal selecionada, com presença de cascalho fino a médio, localmente argilosa e espessura indeterminada.

A profundidade do lençol freático oscila entre 7,0 a 7,5 m e o aqüífero existente até a profundidade investigada é de caráter livre e de baixa produtividade. Os valores de carga hidráulica foram obtidos a partir de leituras realizadas em janeiro de 1997 e utilizadas para a confecção do mapa potenciométrico. As linhas equipotenciais, visualizadas na Figura 37, foram elaboradas pela interpolação dos valores de carga hidráulica e o fluxo subterrâneo foi traçado perpendicularmente a estas linhas. A análise deste mapa indica que a direção preferencial de deslocamento do fluxo subterrâneo é de Norte para Sul, no sentido das residências vizinhas ao auto posto e a velocidade do deslocamento do nível d'água é de 1,0 $\mathrm{m} / \mathrm{ano}$.

Em janeiro de 1997 não foi detectada presença de fase livre, no entanto, foi percebido odor de combustível nas sondagens próximas aos tanques de combustível (furos TR 04, 05, 06 e 07). Em abril do mesmo ano, a Cetesb solicitou ao posto nova investigação uma vez que o mapeamento já realizado não havia contemplado o espaço existente atrás do depósito de lubrificantes e no corredor próximo à área de lavagem. Em maio foram instalados mais dois poços de monitoramento PM 05 e PM 06, visando complementar o estudo potenciométrico do local e aumentar a área de mapeamento da possível presença de fase livre, que ainda mostrouse inexistente. Ainda em 1997, foi solicitada pela Cetesb a análise química de BTEX em 
amostras de água subterrânea, a serem apresentadas em setembro de 1997, março e setembro de 1998, porém o posto só se manifestou em dezembro de 1997.

Em janeiro de 1998, a Consultoria D informou que, a partir da leitura do nível d’água obtida em dezembro de 1997, foi confeccionado novo mapa potenciométrico da área, no qual foi possível observar a direção do fluxo preferencial da água subterrânea de Leste para Oeste (Figura 38), diferente do anterior que era de Sul para Norte, (conforme Figura 37). 


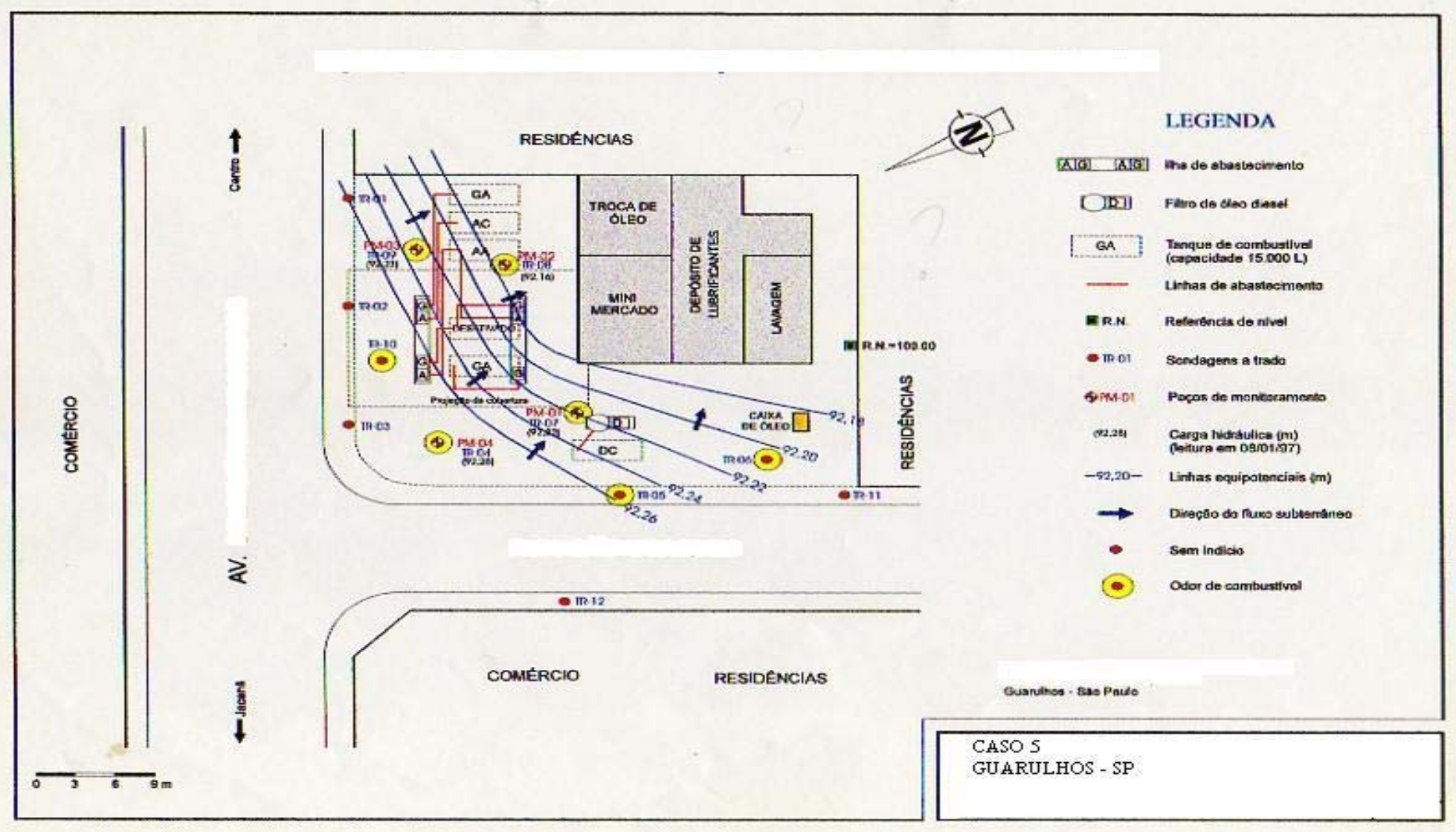

Figura 37 - Caso 5 - Mapa potenciométrico e instalação dos poços de monitoramento 


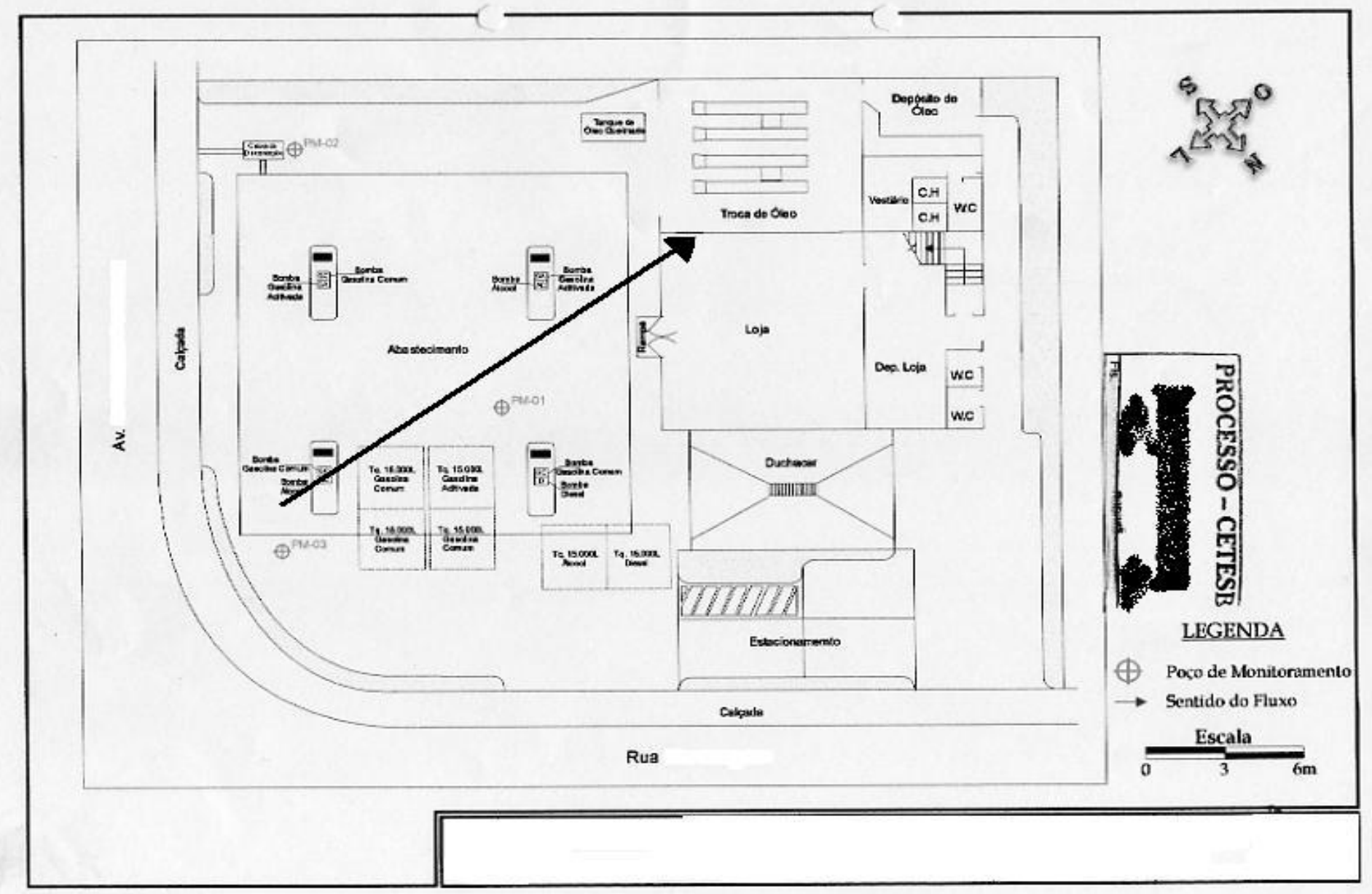

Figura 38 - Caso 5 - Mapa potenciométrico 
Em fevereiro de 1998 ocorreu a amostragem para BTEX, ainda sem que fosse notada presença de fase livre. As medições constantes no relatório desta campanha indicam fluxo subterrâneo de Sul para Norte, como em janeiro de 1997. Na Tabela 21 estão descritos os valores resultantes desta amostragem. As delimitações de fase dissolvida segundo a Consultoria E, podem ser vistas nas Figuras 38, 39, 40 e 41 que se seguem.

Tabela 21 - Caso 5 - Análise de água subterrânea (fevereiro de 1998)

\begin{tabular}{cccccc}
\hline Local & $\begin{array}{c}\text { Identificação } \\
\text { da amostra }\end{array}$ & $\begin{array}{c}\text { Benzeno } \\
(\boldsymbol{\mu g} / \mathbf{L})\end{array}$ & $\begin{array}{c}\text { Tolueno } \\
(\boldsymbol{\mu g} / \mathrm{L})\end{array}$ & $\begin{array}{c}\text { Etilbenzeno } \\
(\boldsymbol{\mu g} / \mathbf{L})\end{array}$ & $\begin{array}{c}\text { Xilenos } \\
(\boldsymbol{\mu g} / \mathbf{L})\end{array}$ \\
\hline PM-01 & AA-01 & $\mathbf{7 7 0 , 0}$ & 200,0 & $\mathbf{8 3 , 0}$ & $\mathbf{5 3 0 , 0}$ \\
PM-02 & AA-02 & $\mathbf{1 7 0 0 , 0}$ & $\mathbf{1 8 0 0 , 0}$ & $\mathbf{5 5 0 , 0}$ & $\mathbf{3 5 0 0 , 0}$ \\
PM-03 & AA-03 & $\mathbf{1 9 0 0 , 0}$ & 480,0 & $\mathbf{4 3 0 , 0}$ & $\mathbf{1 4 0 0 , 0}$ \\
PM-04 & AA-04 & $\mathbf{7 3 0 , 0}$ & 280,0 & $\mathbf{1 7 0 , 0}$ & $\mathbf{7 8 0 , 0}$ \\
PM-05 & AA-05 & $\mathbf{2 1 0 , 0}$ & 60,0 & 13,0 & $\mathbf{1 3 0 , 0}$ \\
PM-06 & AA-06 & $\mathbf{5 9 0 , 0}$ & $\mathbf{5 7 0 , 0}$ & $\mathbf{1 5 0 , 0}$ & $\mathbf{9 0 0 , 0}$ \\
$\begin{array}{c}\text { Lista } \\
\text { Holandesa }\end{array}$ & & 15,0 & 500,0 & 75,0 & 35,0
\end{tabular}

Em agosto de 1998, a Consultoria E informou sobre a instalação de mais 5 PM’s e amostras para BTEX, TPH E PAH's, conforme sugere metodologia RBCA. Ainda em agosto do mesmo ano, em vistoria, a Equipe de Implantação e Avaliação de Tecnologias da Cetesb verificou existência de fase livre no PM-08 e sugeriu retirada da fase livre, apresentação do croqui atualizado com novos PM, análise de risco e monitoramento mensal. No entanto, quanto aos resultados dos monitoramento de fase livre e índice de explosividade, estes devem ser apresentados trimestralmente. 


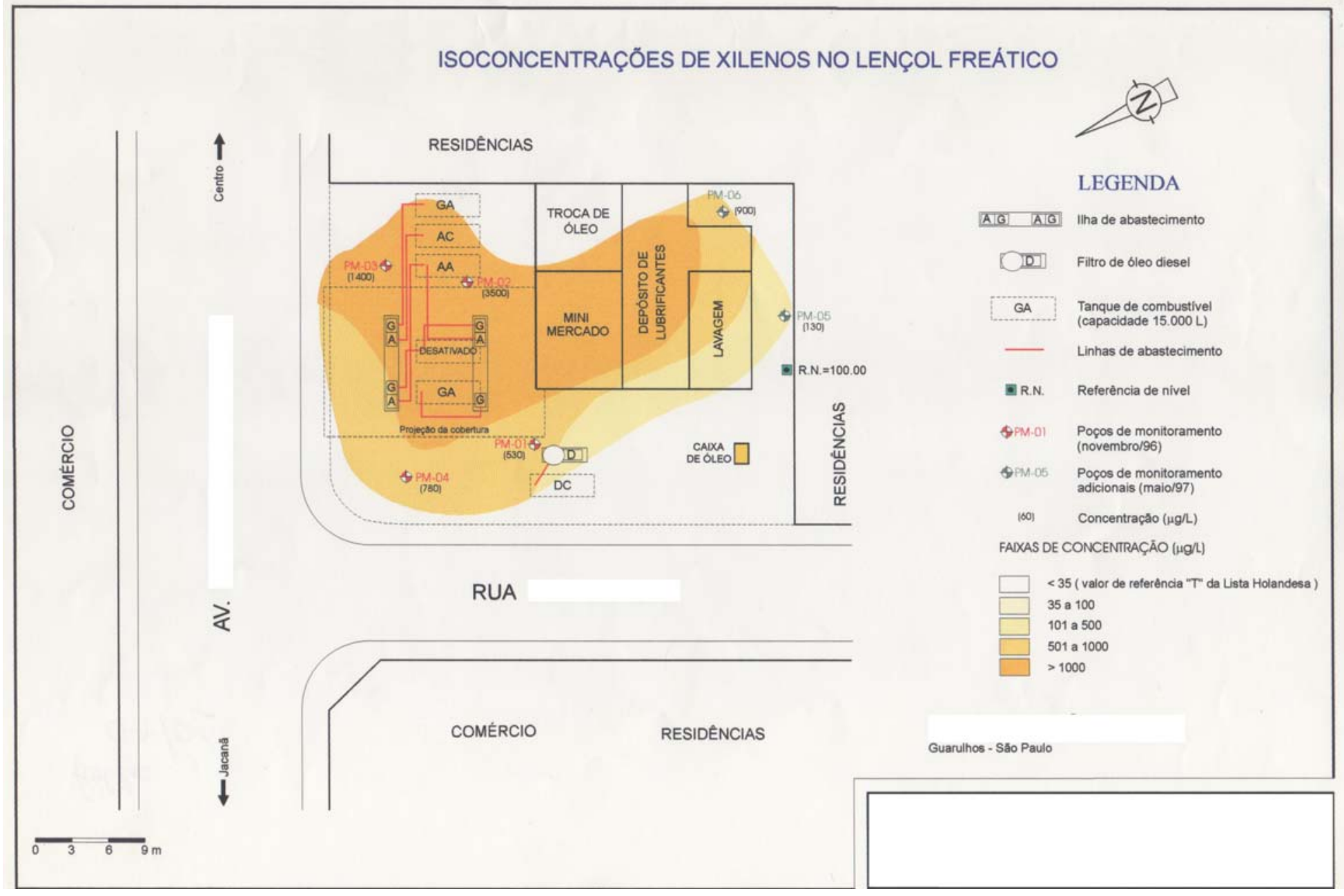

Figura 39 - Caso 5 - Delimitação da pluma de contaminação 


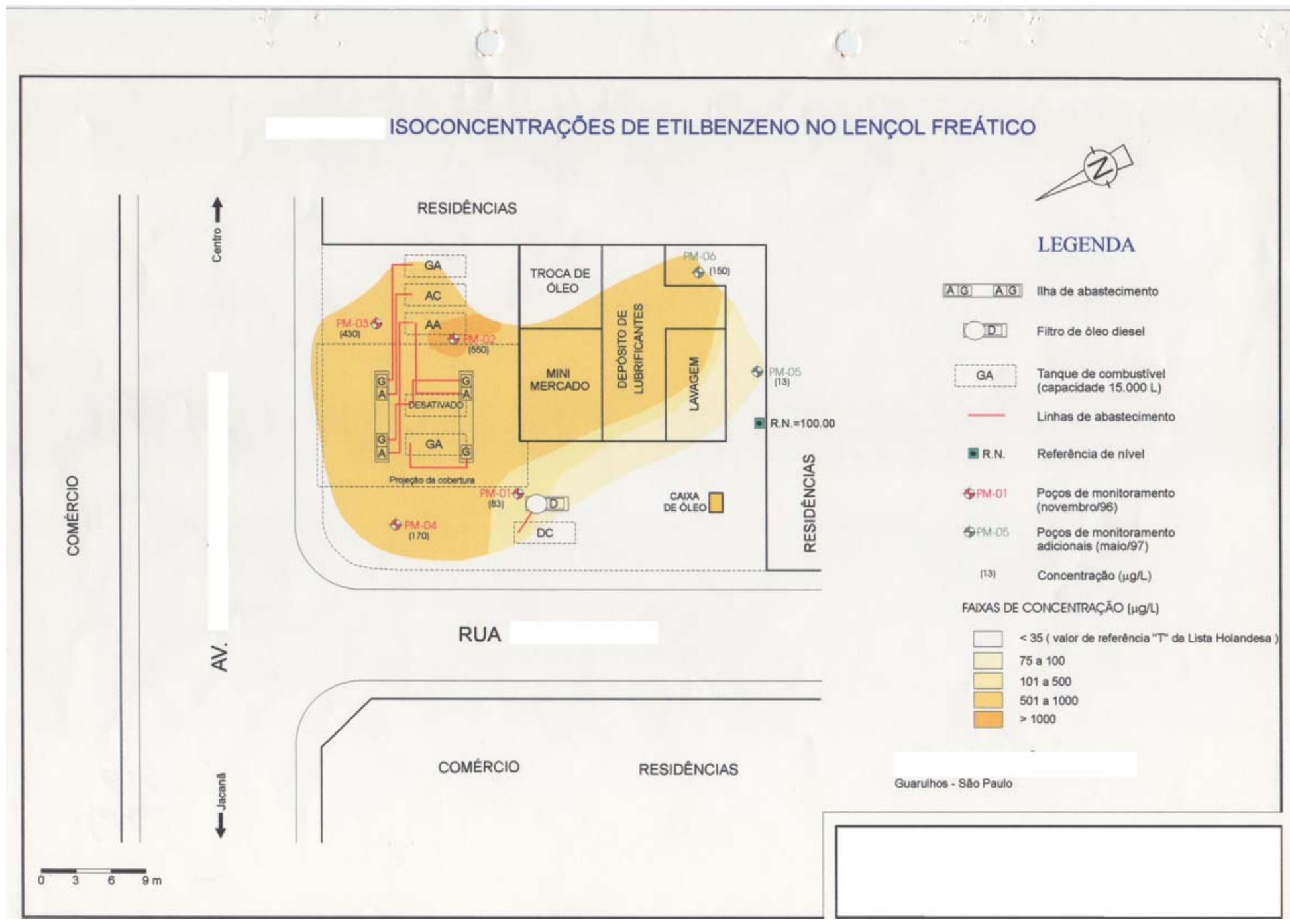

Figura 40 - Caso 5 - Delimitação da pluma de contaminação 


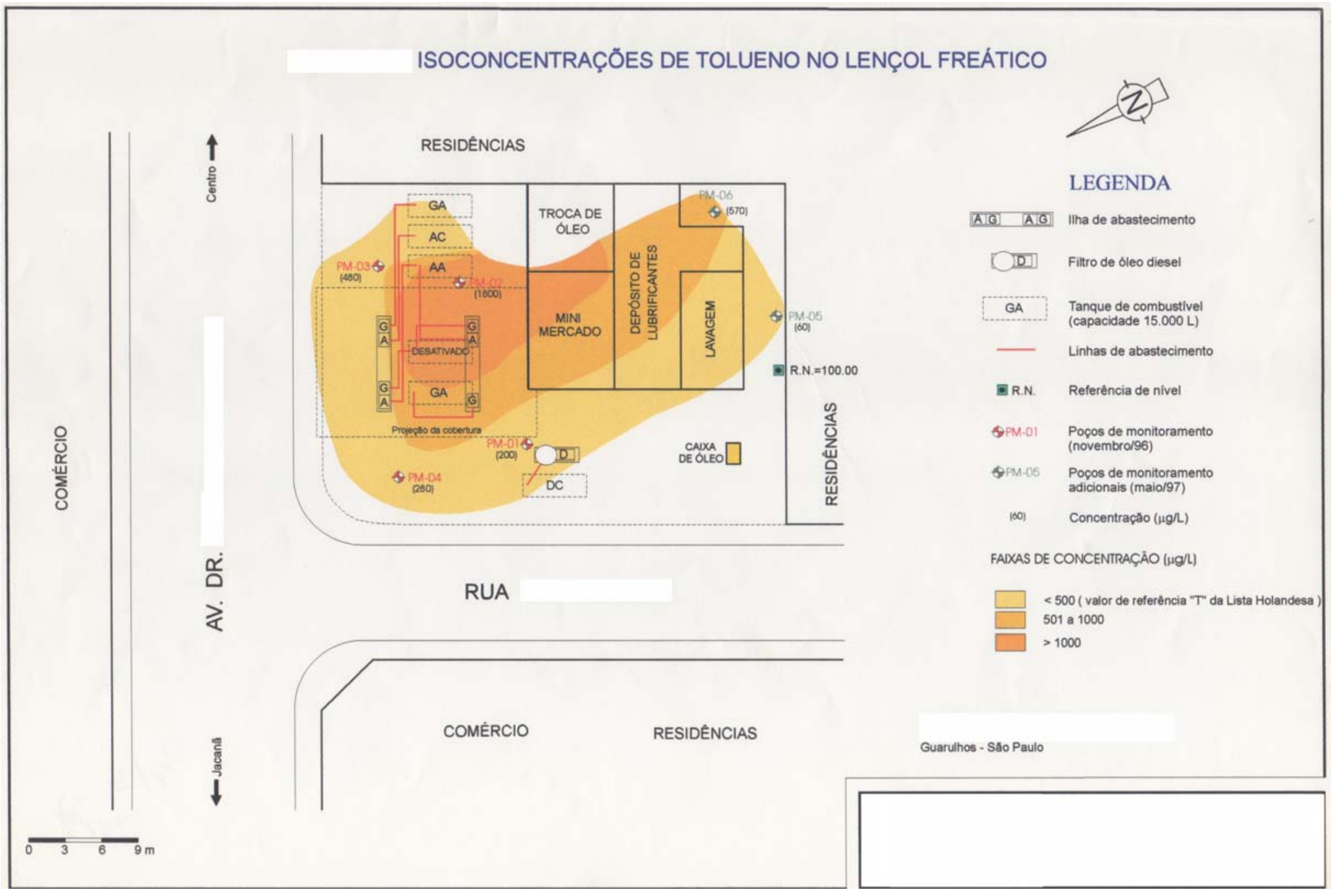

Figura 41 - Caso 5 - Delimitação da pluma de contaminação 


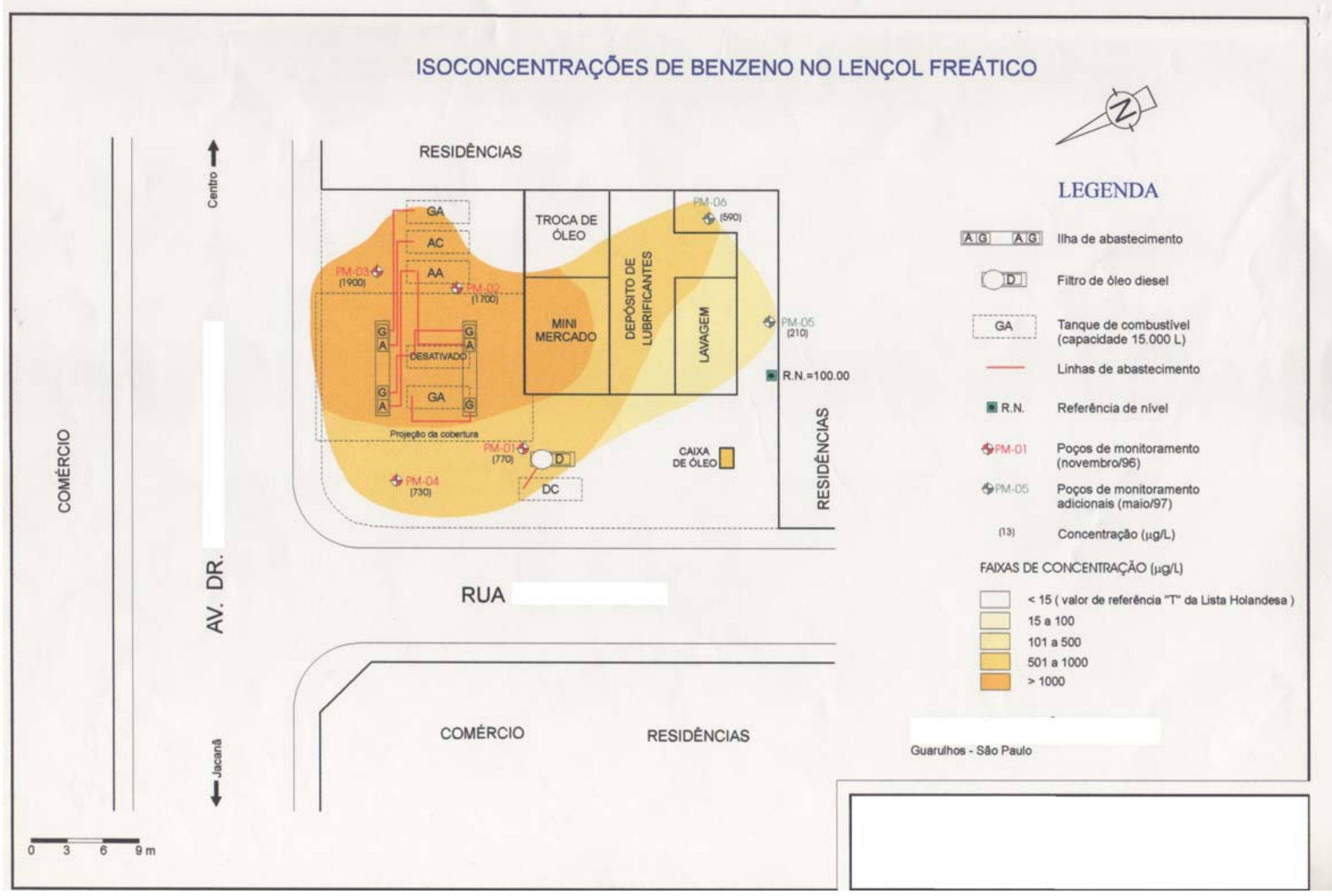

Figura 42 - Caso 5 - Delimitação da pluma de contaminação 
Em dezembro de 1999 foram instalados 3 tanques bicompartimentados de 30,0 $\mathrm{m}^{3}$, sendo destinados a armazenamento de gasolina comum e aditivada, álcool e diesel e 1 tanque de 2,0 $\mathrm{m}^{3}$ para armazenamento de óleo lubrificante usado. Em seguida, foi realizado teste de estanqueidade nos tanques novos. Mas, somente em dezembro de 2002 teve início o Projeto do Laudo de Passivo Ambiental.

O Caso 5 foi convocado para licenciamento em julho de 2002 e solicitou a devida Licença de Operação em abril de 2003, quando apresentou PGR - Plano de Gerenciamento de Risco.

Em amostragem realizada em fevereiro de 2002, concluiu-se que o sentido do fluxo subterrâneo é de Oeste para Leste, conforme é possível observar na Figura 43 e, nas amostras de solo apresentadas, não houve valores de concentrações acima dos parâmetros de valores orientadores da Cetesb, diferente da situação apresentada na água subterrânea (Tabela 22). 


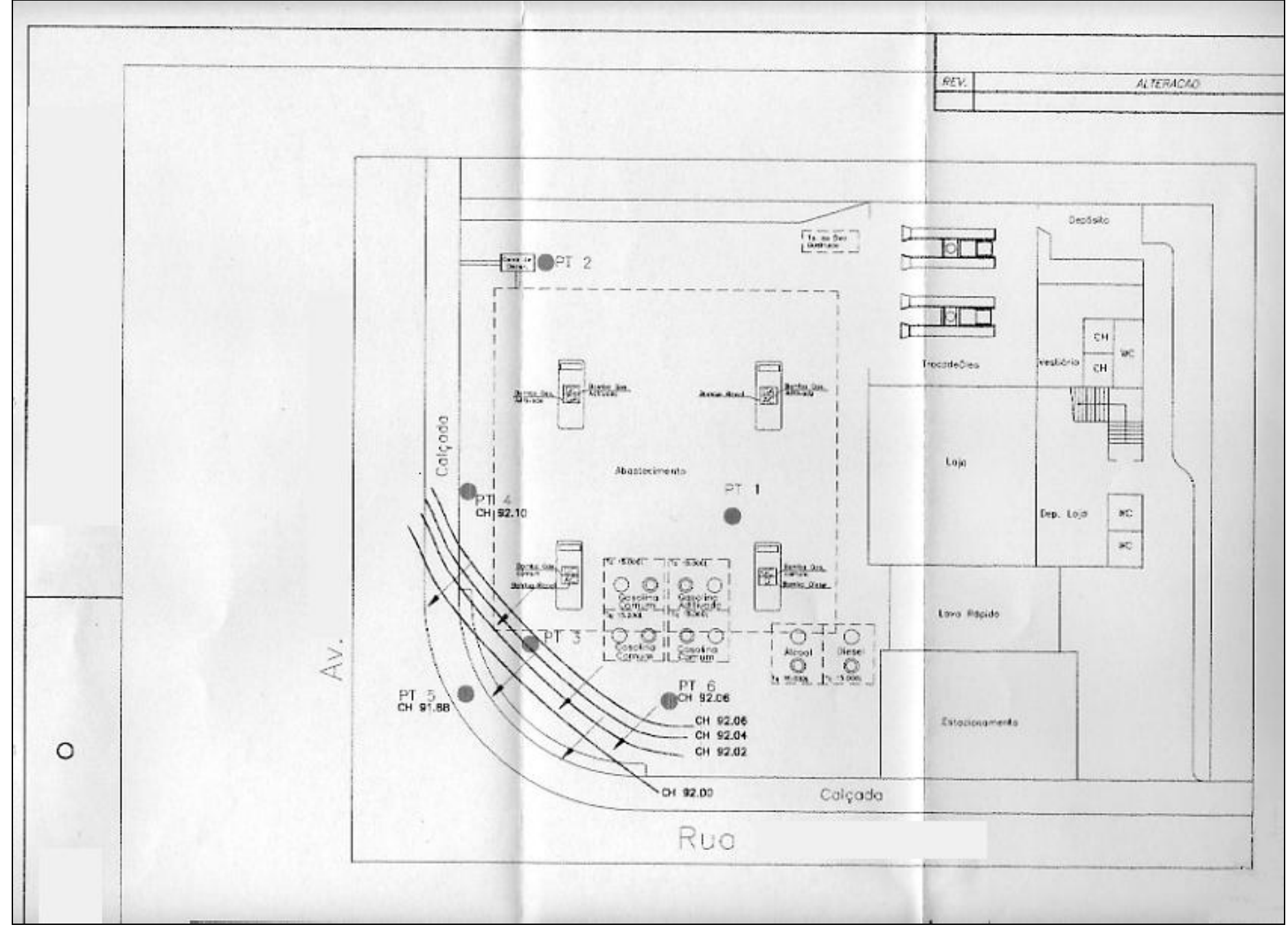

Figura 43 - Caso 5 - Fluxo subterrâneo observado em fevereiro de 2002 
Tabela 22 - Caso 5 - Análises de água subterrânea (fevereiro de 2002)

\begin{tabular}{ccccc}
\hline Local & Benzeno $(\mu \mathrm{g} / \mathrm{L})$ & Tolueno $(\mu \mathrm{g} / \mathrm{L})$ & Etilbenzeno $(\mu \mathrm{g} / \mathrm{L})$ & Xilenos $(\boldsymbol{\mu g} / \mathrm{L})$ \\
\hline PM-01 & $\mathbf{5 8 , 4}$ & $\mathbf{5 1 7 , 0}$ & $\mathbf{2 0 4 , 0}$ & $\mathbf{1 0 9 7 , 0}$ \\
PM-02 & $\mathbf{1 7 0 0 , 0}$ & $\mathbf{1 8 0 0 , 0}$ & $\mathbf{5 5 0 , 0}$ & $\mathbf{3 5 0 0 , 0}$ \\
PM-03 & $\mathbf{1 9 0 0 , 0}$ & $\mathbf{4 8 0 , 0}$ & $\mathbf{4 3 0 , 0}$ & $\mathbf{1 4 0 0 , 0}$ \\
PM-04 & $\mathbf{7 3 0 , 0}$ & $\mathbf{2 8 0 , 0}$ & $\mathbf{1 7 0 , 0}$ & $\mathbf{7 8 0 , 0}$ \\
Valores & 5,0 & 170,0 & - & 300,0 \\
orientadores* & & & &
\end{tabular}

*Valores orientadores da Cetesb, 2001

Embora as concentrações apresentadas estejam excedendo os valores dos níveis aceitáveis baseados no risco (NABR), como a região não é abastecida com a utilização de água subterrânea através de poços, estas concentrações não oferecem risco à saúde humana.

Em Laudo de Passivo Ambiental entregue em janeiro de 2003, no qual pode-se verificar os valores de concentração de compostos BTEX na água subterrânea conforme Tabela 23.

Tabela 23 - Caso 5 - Análises de água subterrânea (janeiro de 2003)

\begin{tabular}{ccccc}
\hline Local & Benzeno $(\mu \mathrm{g} / \mathrm{L})$ & Tolueno $(\mu \mathrm{g} / \mathrm{L})$ & Etilbenzeno $(\boldsymbol{\mu g} / \mathrm{L})$ & Xilenos $(\boldsymbol{\mu g} / \mathrm{L})$ \\
\hline PM-01 & $\mathbf{5 8 , 4}$ & $\mathbf{5 1 7 , 0}$ & $\mathbf{2 0 4 , 0}$ & $\mathbf{1 0 9 7 , 0}$ \\
PM-02 & $<0,02$ & $<0,02$ & $<0,02$ & $<0,02$ \\
PM-03 & $<0,02$ & $<0,02$ & $<0,02$ & $<0,02$ \\
Valores & 5,0 & 170,0 & - & 300,0 \\
orientadores* & & & \\
*Valores orientadores da Cetesb, 2001 & & \\
0,02 é o limite de detecção & &
\end{tabular}

No mesmo Laudo de Passivo Ambiental (janeiro de 2003), têm-se os valores de concentração de compostos BTEX no solo que estão descritos na Tabela 24. 
Tabela 24 - Caso 5 - Análises de solo (janeiro de 2003)

\begin{tabular}{ccccc}
\hline Local & Benzeno $(\boldsymbol{\mu g} / \mathbf{k g})$ & Tolueno $(\boldsymbol{\mu g} / \mathbf{k g})$ & Etilbenzeno $(\boldsymbol{\mu g} / \mathbf{k g})$ & Xilenos $(\boldsymbol{\mu g} / \mathbf{k g})$ \\
\hline S-01 & 421,0 & $<0,02$ & $<0,02$ & $<0,02$ \\
S-02 & $<0,02$ & $<0,02$ & $<0,02$ & $<0,02$ \\
S-03 & $<0,02$ & $<0,02$ & $<0,02$ & $<0,02$ \\
S-04 & $<0,02$ & $<0,02$ & $<0,02$ & $<0,02$ \\
Valores & 1500,0 & 40000,0 & - & 6000,0 \\
orientadores* & & & \\
*Valores orientadores da Cetesb (2001) & & \\
0,02 é o limite de deteção &
\end{tabular}

No novo Laudo de Passivo Ambiental datado de março de 2004, os resultados para os parâmetros BTEX são idênticos aos de janeiro de 2003.

O Caso 5 apresentou à Cetesb o Laudo de Passivo Ambiental e Avaliação de Risco RBCA - Tier I em março de 2004 e assinou o TAC em setembro do mesmo ano. O posto em questão obteve a Licença de Operação em junho de 2005. Depois disto, não consta no processo mais nenhum monitoramento.

O Caso 5 contratou para execução dos planejamentos, remediações, reformas remediação da contaminação e análises laboratoriais sete empresas. 


\section{TRATAMENTO DE DADOS}

É importante comentar que o gerenciamento de uma contaminação envolve a remoção de fase livre de produto, a investigação da contaminação remanescente, a avaliação e gerenciamento de riscos e finalmente as medidas de remediação. Os 5 casos analisados apresentaram remoção de fase livre do produto e, em dois deles, também investigação da contaminação remanescente, porém, nenhum deles apresentou plano de remediação para avaliação do órgão ambiental.

Em uma área contaminada por hidrocarbonetos o primeiro passo é cessar a fonte de contaminação. Uma vez que o objeto deste estudo é posto de combustíveis, é comum que a fonte de contaminação seja o tanque de abastecimento enterrado, ou alguma das tubulações, a bomba de gasolina, ou mesmo algum acidente que possa ocorrer durante a descarga de combustíveis. Os casos estudados, com exceção do Caso 3, mostraram que foi obedecida a instrução inicial de cessar esta fonte, removendo o tanque ou a tubulação com vazamento. No entanto, o que ocorreu em alguns casos, é que não se tratava de uma única fonte, ou seja, que a contaminação, mesmo cessada a fonte inicial, continuava a aumentar por haver ainda outra fonte contaminando, que pode ter iniciado o vazamento depois da fonte inicial cessada, aumentando assim, o tempo de bombeamento da fase livre de combustível. Porém, não é possível descartar a informação de que o combustível retido no solo por capilaridade ou por adsorção, nas fases residual e adsorvida, torna-se uma fonte contínua de contaminação (FERREIRA, 2000).

O Caso 3 é o único dos analisados que não efetuou reforma desde sua instalação realizada em 1983, os demais já realizaram reformas inclusive contempladas com troca dos tanques e, mesmo assim, a contaminação continua presente. Um exemplo deste problema é o Caso 4, que efetuou reforma em 1997 e reforma parcial do piso em 2001, após utilização de 
“bombeamento e tratamento” (1995). Continua bombeando sempre que apresenta fase livre de combustível nos monitoramentos que executa. Isto pode indicar que o solo ainda contém combustível e que as propriedades físico-químicas deste contaminante, somadas às características hidrogeológicas do local, permitem que o fluido fique transitando de uma fase para a outra, reiniciando o aparecimento de fase livre nos poços de monitoramento.

Embora todos os casos analisados tenham comunicado à Cetesb e apresentado documentação quanto à remoção de fase livre e monitoramento, nenhum deles apresentou um projeto de remediação. No entanto, o que motivou a escolha do Caso 3 para apresentação da proposta de remediação, é que este foi o único que não realizou reforma. Como o solo pode ser considerado uma fonte constante de contaminação do lençol freático, por conter combustível em fase residual ou adsorvida, não é de causar estranheza o fato de que, para que ocorra remediação completa da área, faz-se necessária a remoção do solo para tratamento ex situ.

A maioria das contaminações está restrita à área do posto. Nas situações avaliadas por este trabalho, pode-se perceber que nos Caso 3 e Caso 4, a contaminação extrapolou os limites do empreendimento, as demais não chegaram a sair das instalações do posto. Com a diferenciação de que no Caso 4, calcula-se que a pluma de contaminação tenha alcançado apenas a calçada do próprio posto não tendo atingido o território subterrâneo de nenhum imóvel vizinho, enquanto que no Caso 3, a pluma já deve ter-se expandido por baixo de, no mínimo, 11 imóveis entre residências e estabelecimentos comerciais.

Em todos os casos estudados, a contaminação já atingiu as águas subterrâneas e todos já se encontram removendo fase livre. Porém, após a remoção da fase livre e dissolvida, serão necessárias novas análises laboratoriais dos parâmetros tratados para a verificação da qualidade destas águas, só assim, será possível avaliar a possibilidade de recuperação das mesmas.

Nos processos analisados, foram constatadas algumas contradições descritas pelas 
consultorias na elaboração dos relatórios e das análises de risco. Estas contradições podem ser provenientes de informações inconsistentes fornecidas pelo proprietário ou mesmo por empregados do posto. Ou ainda, por desconhecimento da importância dos detalhes referentes ao imóvel ou à contaminação em si, por parte dos profissionais envolvidos, principalmente por tratar-se de um assunto pouco explorado no Brasil.

É sabido que os custos empregados em remoção de fase livre, ou bombeamento e tratamento, ou outros tipos de tratamento in situ efetivados nas remediações das água subterrâneas, ocorrem diluídos nos diversos anos em que ocorrerá esta retirada da fase livre. No entanto, os custos para remediações ex situ, que remove o solo para tratamento ou disposição adequada, embora possam parecer maiores em princípio, ocorrem apenas uma vez, além de extinguir completamente a contaminação. Assim, não haverá mais a passagem de fluido da fase adsorvida ou residual para a fase livre, acabando também com a necessidade de nova remoção de fase livre, que é comum ocorrer por vários anos quando não se remove o solo. Este reaparecimento de fase livre, só ocorrerá no caso de um novo vazamento que será mais difícil de ocorrer, uma vez que a remoção de solo os tanques de combustíveis e tubulações foram instalados recentemente, em conformidade com as normas ABNT e com todos os testes de estanqueidade realizados.

Dos 5 postos analisados, apenas em 2 deles há registro de reclamações da população. No Caso 3, ainda não é possível perceber os benefícios da atuação do órgão ambiental, pois embora a Cetesb já tenha autuado o estabelecimento com 3 AIIPA’s e 2 AIIPM’s, este ainda não realizou a reforma necessária e não cessou a fonte de contaminação. Já no Caso 5, após as incursões e ações da Cetesb e da reforma realizada em dezembro de 1999, não há registro de nenhuma reclamação da população vizinha desde setembro de 1996. 


\section{RESULTADO: PROPOSTAS DE REMEDIAÇÃO}

A descontaminação de solo que este trabalho propõe não avaliou os custos do projeto, considerando apenas a melhor tecnologia aplicável ao local.

Um projeto de remediação deve ser elaborado, para ser utilizado como a base técnica para o órgão gerenciador ou órgão de controle ambiental avaliar a possibilidade de autorizar

ou não a implantação e operação dos sistemas de remediação propostos. Desta forma, o projeto deverá conter todas as informações sobre a área contaminada, levantadas nas etapas anteriores do gerenciamento.

Com base nos levantamentos apresentados no capítulo 3 deste trabalho, uma vez que dos casos analisados somente o Caso 3 e o Caso 5 ainda apresentaram, até junho de 2006, concentrações de contaminantes acima do permitido pela legislação e ambos oferecem risco à saúde humana, além de não terem apresentado proposta de remediação, optou-se por apresentar e discutir as melhores tecnologias que podem ser aplicadas aos dois casos acima citados.

Com relação ao Caso 1, como relatado anteriormente, são necessárias novas análises e nova elaboração do ACBR. A última análise apresentada, datada de maio de 2005 informou que, em águas subterrâneas, os valores para BTEX não alcançaram os limites estabelecidos pela Portaria n 1469 de 28/12/2000 - Qualidade de água para consumo humano, no entanto, diante das contradições verificadas nos documentos constantes no processo, bem como da informação que estava ocorrendo remoção de fase livre, estas análises podem estar incorretas.

O Caso 3 ainda não efetuou reforma, isto será um elemento facilitador para a efetivação da remediação. A contaminação inicialmente percebida era de óleo diesel, no entanto, a Consultoria E em monitoramento realizado em 1999, percebeu gasolina nos subsolo do posto e as análises laboratoriais apresentadas, em abril de 2004 (Tabelas 16a, 16b e 16c), 
mostram presença de compostos BTEX o que é uma característica de contaminações por gasolina.

Um projeto de remediação deve conter uma série de informações, além do projeto em si. São elas: histórico completo do posto, descrição geológica e hidrogeológica, plantas em escala contendo as dimensões do posto, localização dos tanques, bombas e tubulações existentes, detalhamento da (s) tecnologia (s) escolhida (s), detalhamento da implantação e operação do sistema de remediação, cronograma de atividades, se a tecnologia escolhida apresentar a necessidade de remoção de solo, é preciso que se tenha a estimativa da quantidade de solo a ser removido, os planos de segurança dos trabalhadores e vizinhança e o plano de monitoramento da eficiência do sistema, com pontos de coleta de dados definidos, parâmetros a serem analisados, freqüência de amostragem e os limites ou padrões definidos como objetivos a serem atingidos pela remediação para interpretação dos resultados.

Para este caso, tendo em vista a não remoção da (s) fonte (s) de contaminação, faz-se necessária reforma urgente, inclusive para adequação ao licenciamento ambiental que exige reforma completa, incluindo troca dos tanques instalados há mais de 15 anos. E, além da pluma de contaminação ser bastante extensa, as instalações do posto datam de 1983, ou seja, os tanques já têm mais de 20 anos, estando propensos a apresentar vazamentos e a velocidade de migração das águas subterrâneas estimada é de 38 m/ano.

Como pode ser observado no item 4.3 o entorno do Caso 3 é composto por residências, escola e pequenos comércios, sendo que além do próprio posto, muitos estabelecimentos no entorno utilizam-se de captação de água subterrânea através de poços cacimba para consumo doméstico. Assim é prioritária a preservação da segurança dos moradores ou dos comerciantes nos arredores do posto, além dos próprios empregados do posto. Portanto, é necessário, como medida preventiva, a desativação deste poço de forma a evitar a eventual ingestão das águas subterrâneas impactadas e/ou o contato dermal por parte dos trabalhadores do posto. 
Como a pluma de contaminação estimada através do levantamento realizado já se encontra externa aos limites do empreendimento estendendo-se pelo subsolo de algumas residências e empreendimentos (Figura 43), não é possível que seja utilizada a remoção de todo solo contaminado para tratamento ex situ, embora seja o mais aconselhável para uma situação em que os tanques e a tubulação ainda não tenham sido retiradas. No entanto, com a remoção dos tanques para efetivação da reforma completa, o solo contido nos limites do posto, pode ser mais facilmente removido para que se possa ser tratado com desadsorção térmica, que pode inclusive ser realizada no próprio posto, com recolocação do próprio solo no local. Para a região fora dos limites deste, pode ser realizada remoção de gases (Air Strippers), pois na Tabela 17 é possível visualizar alta concentração de compostos BTEX para a inalação de vapores orgânicos provenientes do solo em ambientes abertos por receptores residenciais vizinhos off site nos poços de monitoramento existentes nos arredores do posto. Além da execução dos trabalhos de desadsorção térmica e air strippers, deve ser realizado monitoramento para acompanhamento da atenuação natural da contaminação remanescente, inclusive com a utilização de medidas de aceleração da degradação dos hidrocarbonetos dos meios contaminados.

A escolha de, no mínimo três tecnologias para a remediação desta contaminação, deve-se ao tipo de solo que compõe a região, à velocidade de migração das águas subterrâneas que é estimada em 38 m/ano e a direção do fluxo subterrâneo que dificultará o retorno do contaminante para a área do posto. 


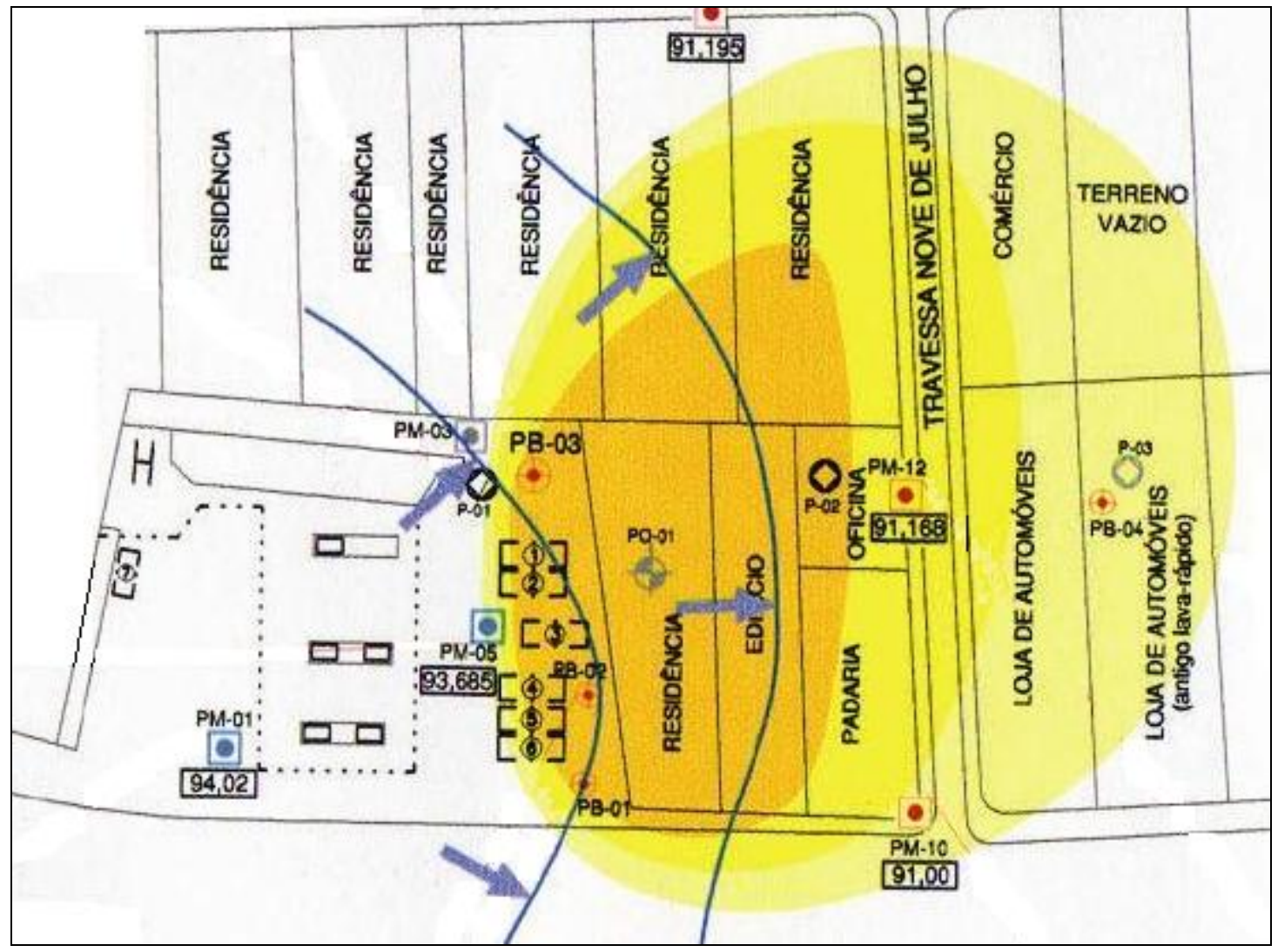

Figura 44 - Caso 3 - Ampliação da delimitação da pluma de contaminação

Para que sejam possíveis a implantação e operação do sistema de remediação, são necessárias algumas complementações de informações, tais como: plantas com todas as medidas das áreas do posto e delimitação da profundidade da pluma de contaminação. No entanto, de posse dos dados já analisados, pode-se considerar que a área do posto é $450 \mathrm{~m}^{2}$, a profundidade máxima do nível d’água determinada nas sondagens realizadas é de 7,0 m e conforme a Figura 43 a pluma de contaminação está ocupando aproximadamente 1/5 do empreendimento. Assim, pode-se estimar que deverá ser removido, aproximadamente 36,0 m³ de solo contaminado, o que só pode ser confirmado após teste piloto. Lembrando que é necessário cuidar da segurança dos imóveis vizinhos, para que não sejam abalados com a retirada dos tanques para troca, nem mesmo da retirada do solo para tratamento.

O solo retirado para tratamento, deverá passar por uma unidade de desadsorção térmica a ser conduzida até o posto para facilitar a recolocação do solo no local de origem, bem como para que sejam minimizados os custos com o transporte do solo. Após a 
recolocação do solo são necessárias novas análises dos parâmetros BETX para que seja determinada a nova delimitação da pluma e seja decidido, qual a melhor tecnologia a ser empregada para aceleração da atenuação natural da contaminação remanescente no local. Para tanto, recomenda-se instalação de 3 PM's adicionais dentro do posto aproximadamente na mesma posição em que estão hoje os PB-01, PB-02 e PB-03 (Figura 43), em substituição aos que serão fatalmente destruídos durante a reforma; implantação de sistema de remoção de gases - Air Strippers; implantação de monitoramento quinzenal do nível d'água dos PM’s e PB's, com o objetivo de identificar a eventual presença de fase livre de produto e, caso necessário, proceder a sua remoção; e monitoramento analítico trimestral das águas subterrâneas para os parâmetros BTEX e PAH, durante 1 ano hidrológico completo, com o intuito de avaliar o comportamento da pluma de fase dissolvida ao longo do tempo.

Uma vez que o nível d’água neste posto não é muito profundo - cerca de 7,0 m - outra possibilidade para remediação desta área é a implantação de um sistema de extração multifásica - MPE, para que sejam retiradas a fase livre, a água subterrânea com compostos dissolvidos e o vapor do solo, todos em um só sistema. No entanto, é importante lembrar que para que qualquer tecnologia empregada apresente um resultado satisfatório, a primeira medida a ser tomada é a eliminação da fonte de contaminação. Em locais como este, o bombeamento da fase livre e dissolvida pode ser realizado por meio da aplicação de vácuo nos poços de extração. As demais recomendações após a eliminação das fases livre e dissolvida são as mesmas: implantação de monitoramento quinzenal do nível d'água dos PM’s e PB's; e monitoramento analítico trimestral das águas subterrâneas para os parâmetros BTEX e PAH.

No Caso 4, embora as instalações sejam mais recentes (aproximadamente 1997), vem ocorrendo uma série de vazamentos e a remoção de fase livre tem sido uma constante no local. Embora as consultorias tenham informado que a fase livre verificada, nas diferentes situações apresentadas no item 4.4, sejam resultantes de diversos vazamentos diferentes, é 
necessário que seja refeita uma avaliação nas tubulações enterradas e aéreas do posto, bem como novo teste de estanqueidade dos tanques.

É necessária a imediata paralisação da captação do poço cacimba, como primeira medida a ser tomada, pois a utilização das suas águas coloca em risco a saúde dos trabalhadores do posto e dos clientes que possam vir a utilizar-se destas águas. Como tecnologia para remediação da área, o baixo nível d’água (3,0 m) e o solo silte argiloso são fatores que indicam a Extração Multi-fásica (MPE) com tratamento adequado. Esta tecnologia é possível neste caso inclusive por tratar-se de pluma que contém contaminante em mais de uma fase. Outra opção é a utilização de Air Strippers para remoção de gases no local, pois, embora as análises realizadas não tenham apresentado risco à exposição humana, ocorreram novos vazamentos o que invalida a análise de risco realizada anteriormente.

Na Figura 45 observa-se que, conforme as análises já realizadas, a pluma de contaminação encontra-se sob a pista de abastecimento e já existem quatro poços que estão sendo utilizados para bombeamento e que podem ser aproveitados para instalação desta nova proposta de remediação. No entanto, assumindo que, em uma nova análise realizada nas instalações do posto, seja constatadas a deterioração dos equipamentos e real necessidade de troca dos tanques e tubulações, com quebra do piso do posto para a retirada dos equipamentos, é recomendado que seja retirado também o solo do local para que tratamento em desadsorção térmica. Desta forma, é possível garantir que o solo no local deixará de ser também uma fonte de contaminação.

Outra alternativa para recuperação deste solo, ainda assumindo a troca dos tanques e tubulações, é a escavação do solo contaminado e a disposição em pilhas do material escavado envolto em plástico, com a instalação de sistema de extração de vapores. Neste caso, o período de exposição à tecnologia é maior, porém tem como vantagem o custo inferior ao tratamento com desadsorção térmica. 


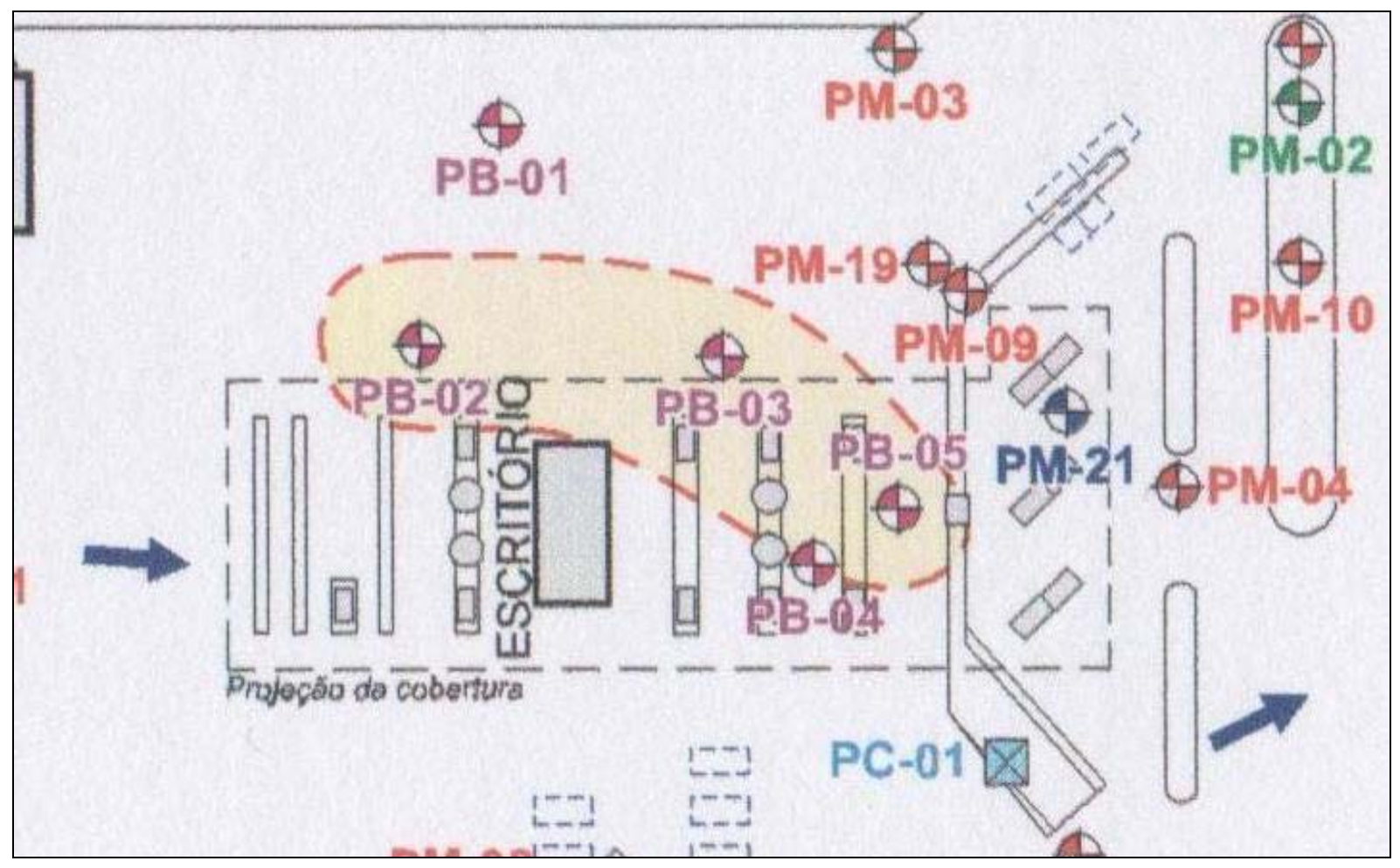

Figura 45 - Caso 4 - Ampliação da delimitação da pluma de contaminação 


\section{CONCLUSÕES}

Os estudos realizados permitiram concluir que:

a) os tanques enterrados a mais de 20 anos têm grande probabilidade de apresentar vazamentos;

b) os combustíveis contendo etanol (gasolina e álcool hidratado) espalham-se mais rapidamente que os combustíveis sem este aditivo;

c) nos casos analisados, é possível perceber os benefícios da atuação do órgão ambiental junto aos postos nos quais ocorreu vazamento, pois, os que tiveram reclamação da população vizinha, após a intervenção da Cetesb, seja com aplicação de AIIPA’s, AIIPM’s, ou com a convocação para solicitação do licenciamento ambiental, estes não foram mais objeto de reclamações da comunidade. No Caso 4, não foi mais notada existência de fase livre no poço da empresa de telefonia e no Caso 5, não houve mais percepção de odor de combustível no estabelecimento comercial. Somente no Caso 3 ainda não foi possível concluir se houve melhora, pois, conforme citado anteriormente, este ainda encontra-se removendo fase livre sem ter realizado a reforma do estabelecimento;

e) com este estudo nota-se que postos de gasolina, quando não tomadas as devidas precauções quanto à qualidade dos equipamentos e instalações, são empreendimentos que apresentam grande potencial poluidor. Os tanques para armazenamento de combustíveis, enterrados há mais de 15 anos, normalmente podem contaminar uma grande área em extensão de solo e também as águas subterrâneas da região na qual ocorreu o vazamento. Este aqüífero pode ser recuperado com tratamento do solo e das águas, no entanto, esta remediação não é simples e requer vários estudos para que seja escolhida a melhor opção de tratamento; e

f) de acordo com a documentação analisada, nos cinco postos, houve redução da pluma de contaminação com a remoção de fase livre, no entanto, é preciso lembrar que o solo 
contaminado com gasolina contendo etanol em fase residual ou adsorvida, pode ser considerado uma fonte incessante de contaminação, uma vez que o combustível transita constantemente de uma fase para outra, justificando assim a constante remoção de fase livre como etapa de remediação aplicada ao local. No entanto, é necessário que seja aplicada uma remediação mais dirigida ao local, como a proposta no item 5 deste trabalho, pois só assim é possível garantir que não haverá mais ocorrência de fase livre, a não ser se for constatado novo vazamento. Porém, é difícil de acontecer novo vazamento quando os equipamentos são novos e testados. Se mesmo com todos os cuidados tomados acontecer algum tipo de perfuração no tanque ou nas tubulações dos postos de combustíveis que estão passando por reformas recentes para atender a convocação da Cetesb, estes possuem equipamentos para que isto seja constatado rapidamente, impedindo que a contaminação seja extensa e profunda; e

g) A ACBR visa estabelecer as concentrações limites nos pontos de exposição identificados, as taxas de ingresso, os riscos associados, bem como as concentrações limites para os compostos de interesse na área em estudo, a fim de assegurar que os receptores identificados não estejam expostos a riscos crônicos à saúde humana, conforme os critérios de riscos adotados (CETESB, 2004). No entanto, dizer que não apresenta risco à saúde humana, não quer dizer que a área não esteja contaminada, assim, mesmo que não apresente risco à saúde humana a área pode estar contaminada e o solo e/ou as águas subterrâneas necessitam alguma remediação. 


\section{REFERÊNCIAS BIBLIOGRÁFICAS}

ACKERMANM, M. Limpeza por meio de extração multifásica de uma área contaminada com vários VOC. In: MOERI, E.; COELHO, R.; MARKER, A. (Ed.). Remediação e revitalização de áreas contaminadas. São Paulo: Signus Editora, 2004.

AMERICAN PETROLEUM INSTITUTE. A guide to the assessment and remediation to underground petroleum releases. 3.ed. Washington, 1996. 1628 p. (API Publication)

BARKER, J. F. et al. The influence of methanol in gasoline fuels on the formation of dissolved plumes, and on the fate ant natural remediation of methanol and BTEX dissolved in groundwater, 1991. In: WEST COST CONFERENCE ON HYDROCARBON CONTAMINATED SOILS AND GROUNDWATER, 1., 1990, Newport Beach. Hydrocarbon contaminated soils and groundwater : analysis, fate, environmental and public health effects, remediation. Chelsea: Lewis, 1991. v. 2.

BEAR, J. Dynamics of fluids in porous media. New York: Dover Publications, 1972. 764 p.

BRASIL. Conselho Nacional do Meio Ambiente. Resolução CONAMA n 273, de 29 de novembro de 2000. Brasília, 2000. Disponível em: < http://www.cetesb.sp.gov.br/licenciamentoo/legislacao/federal/resolucoes/2000_Res_CONA MA_273.pdf >. Acesso em: jan. 2005.

BUCCI, E. M. (2000) Remediação de áreas contaminadas por vazamentos de tanques de combustíveis em postos de serviços. São Paulo, 152 p. Dissertação (Mestrado) Saneamento Ambiental, Universidade Mackenzie de São Paulo.

BUSBY, R. D.; LENHARD, R. J.; ROLSTON, D. E. An investigation of saturationcappilary pressure relations in two and three-fluid systems for several NAPLS in different porous media. Ground Water, Dublin, v. 33, n. 4, p. 570-578, July./Aug. 1995.

CAMARGO, E. C. G.; FELGUEIRAS, C. A.; MONTEIRO, A. M. V. A importância da modelagem da anisotropia na distribuição espacial de variáveis ambientais utilizando procedimentos geoestatísticos. In: X SIMPÓSIO BRASILEIRO DE SENSORIAMENTO REMOTO (SBSR), Paraná, 2001. Resumos... São Paulo: INPE, 2001. p.395-402. Disponível em: $\quad<$ http://marte.dpi.inpe.br/col/dpi.inpe.br/lise/2001/09.14.15.14/doc/0395.402.280.pdf> . Acesso em: mar.2006.

CHATZIS, I.; DULLIEN, F. A. L. Dynamic immiscible displacement mechanisms in pore douplets: theory versus experiment. Journal of Colloid and Interface Science, New York, v. 91, n. 1, p. 199-222, Jan. 1983. 
contaminadas. Banco de Dados. desenvolvido pela Cetesb. São Paulo, 2004. Disponível em: <http://www.cetesb.sp.gov.br/Solo/areas_contaminadas/cadastro.asp $>$. Acesso em: jan. 2005- jun. 2006.

COMPANHIA DE TECNOLOGIA DE SANEAMENTO AMBIENTAL. Ações corretivas baseadas em risco (ACBR) aplicadas a áreas contaminadas com hidrocarbonetos derivados de petróleo e outros combustíveis líquidos - procedimentos. Manual de procedimentos desenvolvido pela Cetesb. São Paulo, 2004. Disponível em: < http://www.cetesb.sp.gov.br/Ambiente/camaras/texto_ca/documentos/acbr.pdf $>$. Acesso em: jan. 2005- jun. 2006.

CONSERVATION OF CLEAN AIR AND WATER IN EUROPE. VOC emissions from loading gasoline onto sea-going tankers in EU-15: control technology and cost-effectiveness. Brussels, 2002. (Report, $\mathrm{n}^{0}$ 6/02). Disponível em: < http://www.concawe.be >. Acesso em: jun. 2005.

CUNHA, R. C. A. Avaliação de risco em áreas contaminadas por fontes industriais desativadas. 1997. 152 f. Tese (Doutorado) - Instituto de Geociências, Universidade de São Paulo, São Paulo, 1997.

DINARDI, A. L.; FORMAGI, V. M.; CONEGLIAN, C. M. R.; BRITO, N. N.; DRAGONI SOBRINHO, G.; TONSO, S.; PELEGRINI, R. Fitorremediação. In: III FÓRUM DE ESTUDOS CONTÁBEIS, 2003, Limeira. Anais... Limeira: Centro Superior de Educação Tecnológica (CESET) e Curso de Tecnologia em Saneamento Ambiental - Laboratório de Pesquisas Ambientais - UNICAMP, 2003. p. 1 - 15.

DULLIEN, F. A. L. Porous media, fluid transport and pore structure. 2 ed. San Diego: Academic Press, 1992. 574 p.

EMPRESA METROPOLITANA DE PLANEJAMENTO DA GRANDE SÃO PAULO. Carta geológica da região metropolitana da Grande São Paulo. Compilado por José Moacyr Vianna Coutinho. São Paulo, 1980. 1 mapa. Escala 1: 100.000.

ESSENCIS. Tecnologias de remediação disponíveis. São Paulo, 200? Disponível em $<$ http://www.essencis.com.br/serv_udt.asp $>$. Acesso em: mai. 2006

ESTADOS UNIDOS. Environmental Protection Agency. Technology Transfer. Site characterization for subsurface remediation. Washington: US Government Printing Office, 1991. 259 p. (Seminar Publication. EPA/625/4-91/026). Disponível em: http://www.epa.gov/OUST/cat/sitchasu.pdf. Acesso em: out. 2005.

FERREIRA, S. B. Estudos laboratoriais para avaliação do potencial de contaminação de água e do solo por gasolina oxigenada. 2000. $229 \mathrm{f}$. Dissertação (Mestrado) - Escola de Engenharia de São Carlos, Universidade de São Paulo, São Carlos, 2000. 
FERREIRA, S. M. Relação entre a espessura real e aparente da gasolina com etanol e da gasolina pura em colunas de laboratório. 2003. 119 f. Dissertação (Mestrado) - Instituto de Geociências, Universidade de São Paulo, São Paulo, 2003.

; OLIVEIRA, E.; DUARTE, U. Comportamento da gasolina com etanol (E-20) e da gasolina pura após a simulação de um vazamento em colunas de laboratório. Revista do Instituto de Geociências, São Paulo, v. 4, p. 91-102, out. 2004.

FETTER, C. W. Contaminant hidrogeology. New York: Macmillan Publishing, 1993. 458 p.

FURTADO, M. Remediação de solo - Para afastar o perigo que se esconde nos subterrâneos das grandes cidades, meios legais e econômicos devem fomentar obras de descontaminação. Revista Química e Derivados, São Paulo, p. 28-44, mai. 2005. Disponível em: $<$ http://www.quimica.com.br/revista/qd437/solos1.htm>. Acesso em: mar. 2006.

GUIAMAIS ONLINE. Guias de ruas e CEP's. São Paulo, 200?. Disponível em: $<$ http://www.guiamais.com.br/ruas/?localeUfId=SP\&localeCityId=Guarulhos $>$. Acesso em: jun. 2006.

HUNTLEY, D.; WALLACE, J. W.; HAWK, R. N. Nonaqueous phase hydrocarbon in a finegrained sandstone: 2. Effect of local sediment variabilitu on the estimation of hydrocarbon volumes. Ground Water, Dublin, v. 32, n. 5, p. p. 778-783, Sept.-Oct. 1994.

HURTADO, A. L. B. Variabilidade da condutividade hidráulica do solo em valores fixos de umidade e de potencial matricial. 2004. $94 \mathrm{f}$. Tese (Doutorado) - Escola Superior de Agricultura “Luiz de Queiroz”, Universidade de São Paulo, São Paulo, 2004.

KOCHINA, P. Ë. Theory of ground water movement. New Jersey: Princeton University, 1952. $613 \mathrm{p}$.

LAGREGA, M. D.; BUCKINGHAM, P. L.; EVANS, J. C. Hazardous waste management. New York: McGraw-Hill, 1994. 1146 p.

LENHARD, R. J.; PARKER, J.C. Estimation of free hydrocarbon volume from fluid levels in monitoring wells. Ground Water, Dublin, v. 28, n. 1, p. 57-67, Jan. 1990.

LOPES, A. G. et al. Manual de gerenciamento de áreas contaminadas. São Paulo: CETESB. Atualizado em outubro de $2001 . \quad$ Disponível em: <http://www.cetesb.sp.gov.br/Solo/areas_contaminadas/manual.asp>. Acesso em: jan. 2006.

MAPLINK. Localize qualquer endereço. São Paulo, 200?. Disponível em: 
$<$ http://maplink.uol.com.br/mapa.asp?aplicativo=sp\&comando=mostra\%20endereco\&enderec $\mathrm{o}=\mathrm{C} 282045-$

R.\%20Dr.\%20Timóteo\%20Penteado\%202002\&legenda=\&enderecoape=\&rota=Y\&maparapi do=\&municipio=GUARULHOS\&bairro=Picanço\&gravar=R.\%20Dr.\%20Timóteo\%20Pentea

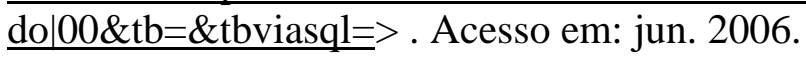

MARKER A. et al. Integral approach to contaminated sites management in urban-industrial agglomerates of developing countries-example São Paulo, Brazil. In: INTERNATIONAL FZK/TNO CONFERENCE ON CONTAMINED SOIL, 5., 1995, Maastricht. Contaminated soil'95. New York: Springer, 1995. p. 99-100.

; GÜNTHER M. A.; CUNHA, R. C. A. Contaminated sites and urban ecology in São Paulo, Brazil. In: BREUSTE, J.; FELDMANN, H.; UHLMANN, O. (Ed.). Urban ecology. New York: Springer, 1998. p. 446-451.

; CUNHA R. C. A.; GÜNTHER M. A. Avaliação de áreas contaminadas na Região Metropolitana de São Paulo. Saneamento Ambiental, São Paulo, v. 4, n. 25, p. 36-39, 1993.

MARTINS, D. O. Estudo do controle de emissões de compostos orgânicos voláteis em tanques de armazenamento de produtos químicos. 2004. $181 \mathrm{f}$. Dissertação (Mestrado) Escola Politécnica - Departamento de Engenharia Ambiental, Universidade Federal da Bahia, Salvador, 2004.

MILLER, A. Remediação de fase livre de gasolina por bombeamento duplo : estudo de caso - São Paulo. 2001. 133 f. Dissertação (Mestrado) - Instituto de Geociências, Universidade de São Paulo, São Paulo, 2001.

MOERI, E.; COELHO, R.; MARKER, A. (Ed.). Remediação e revitalização de áreas contaminadas. São Paulo: Signus Editora, 2004.

MORRISON, R.; BOYD, R. Alcanos - Substituição de radicais. In: Química orgânica. Lisboa: Fundação Calouste Gulbenkian, 1973. p. 93-142.

NEGRÃO, P. Extração de compostos orgânicos voláteis de águas subterrâneas através de air strippers. Clean News. São Paulo, n. 05, 2002. Disponível em: $<$ http://www.clean.com.br/artigos/cleannews/cleannews5_strippers.pdf $>$. Acesso em: mar/2006.

NOBRE, M. M.; NOBRE, R. C. M. Remediação de solos - técnicas alternativa melhoram desempenho. Revista Química e Derivados. São Paulo, n. 417, 2003. Disponível em: < http://www.quimica.com.br/revista/qd417/solo1.htm>. Acesso em: mar/2006.

OLIVEIRA, E. Contaminação de aqüíferos por hidrocarbonetos provenientes de 
vazamentos de tanques de armazenamento subterrâneo. 1992. 112 f. Dissertação (Mestrado) - Instituto de Geociências, Universidade de São Paulo, São Paulo, 1992.

Ethanol flushing of gasoline residuals - microscale and field scale experiments. 1997. 291 f. Tese (Doutorado) - University of Waterloo, Waterloo, 1997.

; BARKER, J.; BANKS, J. Efeitos da variação do nível d’água em fase livre de gasolina pura e de gasolina com etanol. In: CONGRESSO BRASILEIRO DE ÁGUAS SUBTERRÂNEAS, 10., São Paulo, 1998. Resumos... São Paulo: ABAS, 1998. p.10.

PENNER, G. C. Estudos laboratoriais da contaminação do solo por gasolina com o uso de detetor de fotoionização. 2000. 107 f. Dissertação (Mestrado) - Escola de Engenharia São Carlos, Universidade de São Paulo, São Carlos, 2000.

PEREIRA, M. A. C. Alteração da espessura da fase livre da gasolina sob ação cosolvente do etanol. 2000. 85 f. Dissertação (Mestrado) - Instituto de Geociências, Universidade de São Paulo, São Paulo, 2000.

PREFeITURA DE GUARUlhOS. Portal da cidade de Guarulhos. 2003. Disponível em: $<$ http://www.guarulhos.sp.gov.br $>$. Acesso em: ago. 2005.

ROCHE, R. Vamos entender o que é remediação e seus métodos? Disponível em: $<$ http://www.postoecologico.com.br/artigos2.php?id_artigo=25 $>$. 2006. Acesso em: mai. 2006.

RUSSEL, J. B. Concentração e solubilidade. In: Química geral. São Paulo: McGraw-Hill do Brasil, 1981. p. 347-360.

SÁNCHEZ, L. E. A desativação de empreendimentos industriais: um estudo sobre o passivo ambiental. 1998. 178 f. Tese (Livre-Docência) - Escola Politécnica, Universidade de São Paulo, São Paulo, 1998.

Revitalização de Áreas Contaminadas. In: MOERI, E.; COELHO, R.; MARKER, A. (Ed.). Remediação e revitalização de áreas contaminadas. São Paulo: Signus Editora, 2004.

SÃO PAULO (Estado). Região metropolitana de São Paulo. 2006. Disponível em: <www.stm.sp.gov.br>. Acesso em: mai.2006.

SÃO PAULO (Estado). Secretaria do Meio Ambiente. Resolução SMA n 5, de 28 de março de 2001. Dispõe sobre a aplicação e o licenciamento ambiental das fontes de poluição a que se refere a Resolução n. 273, de 29 de novembro de 2000, do Conselho Nacional do Meio Ambiente (CONAMA). São Paulo: CETESB. Disponível em: 
<http://www.cetesb.sp.gov.br/licenciamentoo/legislacao/estadual/resolucoes/resolucoes.asp $>$. Acesso em: jan. 2005.

SCHENK, T. Desenvolvimento e aplicação de técnicas microbiológicas progressivas para a remediação de contaminantes orgânicos no solo e nas águas subterrâneas. In: MOERI, E.; COELHO, R.; MARKER, A. (Ed.). Remediação e revitalização de áreas contaminadas. São Paulo: Signus Editora, 2004.

SILVA, C. C. G. Otimização de uma unidade de air stripping para remover BTEX de águas residuárias. 2004. 251 f. Dissertação (Mestrado) - Faculdade de Engenharia Química, Universidade Estadual de Campinas, Campinas, 2004.

SONG, S. O papel da análise de risco na remediação de áreas contaminadas. In: MOERI, E.; COELHO, R.; MARKER, A. (Ed.). Remediação e revitalização de áreas contaminadas. São Paulo: Signus Editora, 2004.

STIER, T. Seguindo as tendências das tecnologias de remediação. Será que às vezes não escolhemos a abordagem errada? In: MOERI, E.; COELHO, R.; MARKER, A. (Ed.). Remediação e revitalização de áreas contaminadas. São Paulo: Signus Editora, 2004.

TECHOHIDRO. Tecnologias. São Paulo, 200? Disponível em $<$ http://www.tecnohidro.com.br/tec04.htm>. Acesso em: mar. 2006.

WINGE, M. (Coord.). Glossário Geológico Ilustrado. 2001-2006. Disponível em: <http://www.unb.br/ig/glossario/verbete/anisotropia.htm>. Acesso em: mar. 2006. 


\section{ANEXOS}

ANEXO A - Sub-Anexo 01 - Níveis de Avaliação Baseados no Risco (NABR) - valores (referência no texto sobre ACBR)

ANEXO B - Lista Holandesa

ANEXO C - Valores orientadores para solos e águas subterrâneas no Estado de São Paulo 2001

ANEXO D - Valores orientadores para solos e águas subterrâneas no Estado de São Paulo 2005 
ANEXO A

Níveis de Avaliação Baseados no Risco (NABR) 
(a que se refere o artigo 1ํ, inciso VII, alínea "a", da Decisão de Diretoria n 010/2006/C)

\section{TABELAS DE REFERÊNCIA NÍVEIS ACEITAVEIS BASEADOS NO RISCO ESTADO DE SÃO PAULO}

(1) Os valores de RBSL calculados são comparados com os limites físicos de Solubilidade em Água (<S), Concentração de Saturação de Vapor (< Csat,vap) e Concentração de Saturação no Solo (< Csat,solo). Se o valor calculado estiver for a destes limites, este é considerado como for a da realidade e está apresentado na tabela em itálico.

(

2) NA - Não Aplicável 


\begin{tabular}{|l|c|}
\hline NOME: & BENZENO \\
\hline CAS RN: & $71-43-2$ \\
\hline FORMULA: & C6H6 \\
\hline
\end{tabular}

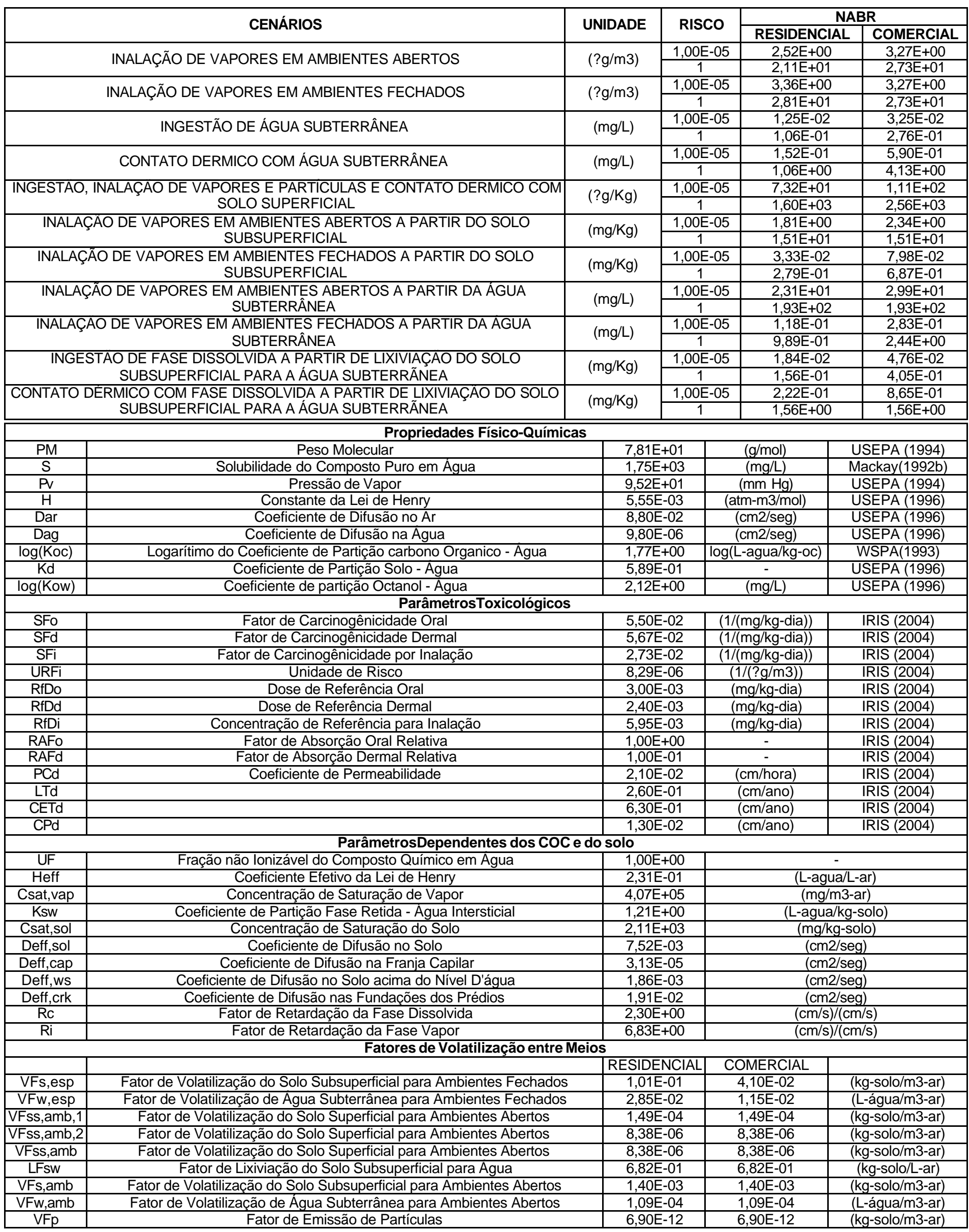




\begin{tabular}{|l|c|}
\hline NOME: & ETILBENZENO \\
\hline CAS RN: & $100-41-4$ \\
\hline FÓRMULA: & C6H10 \\
\hline
\end{tabular}

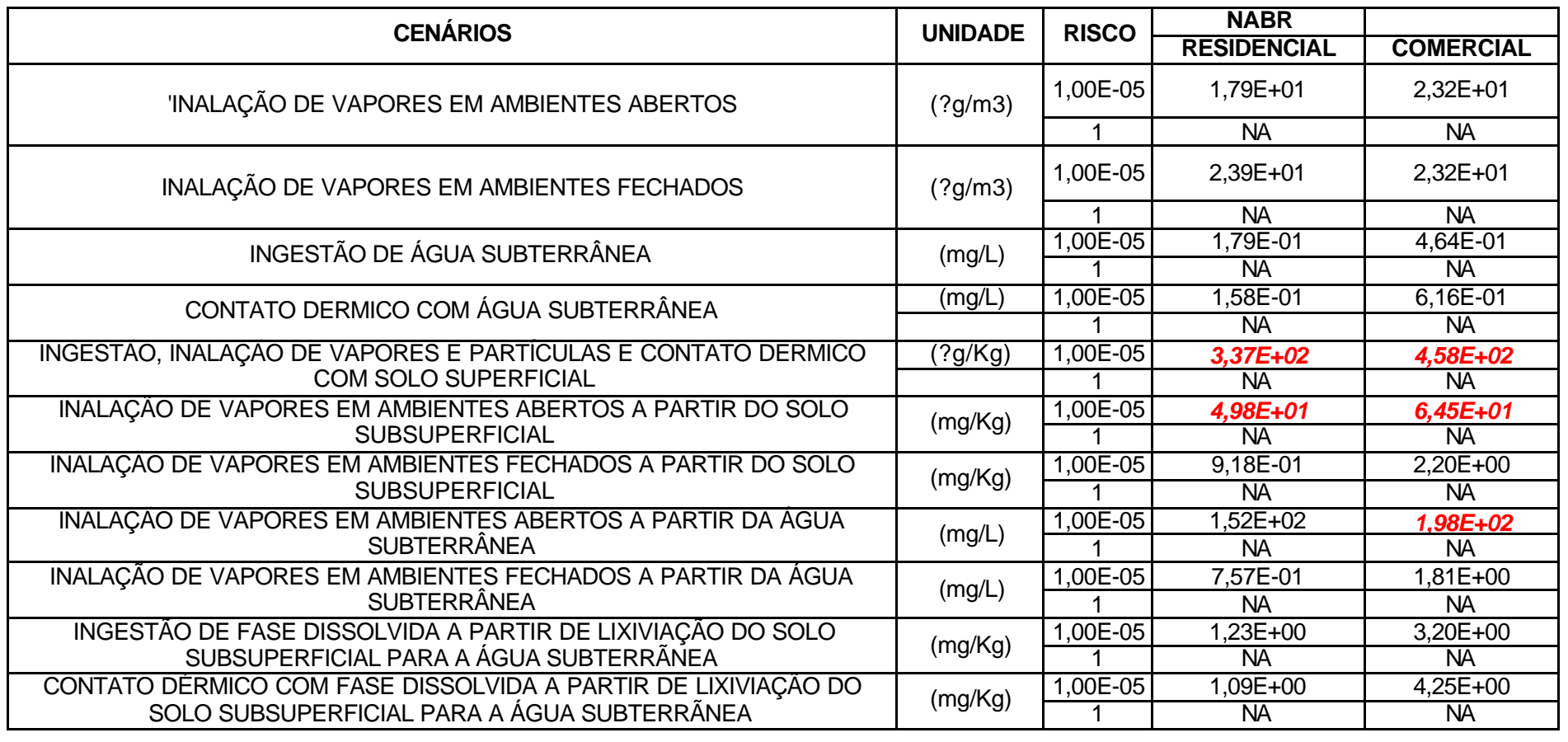

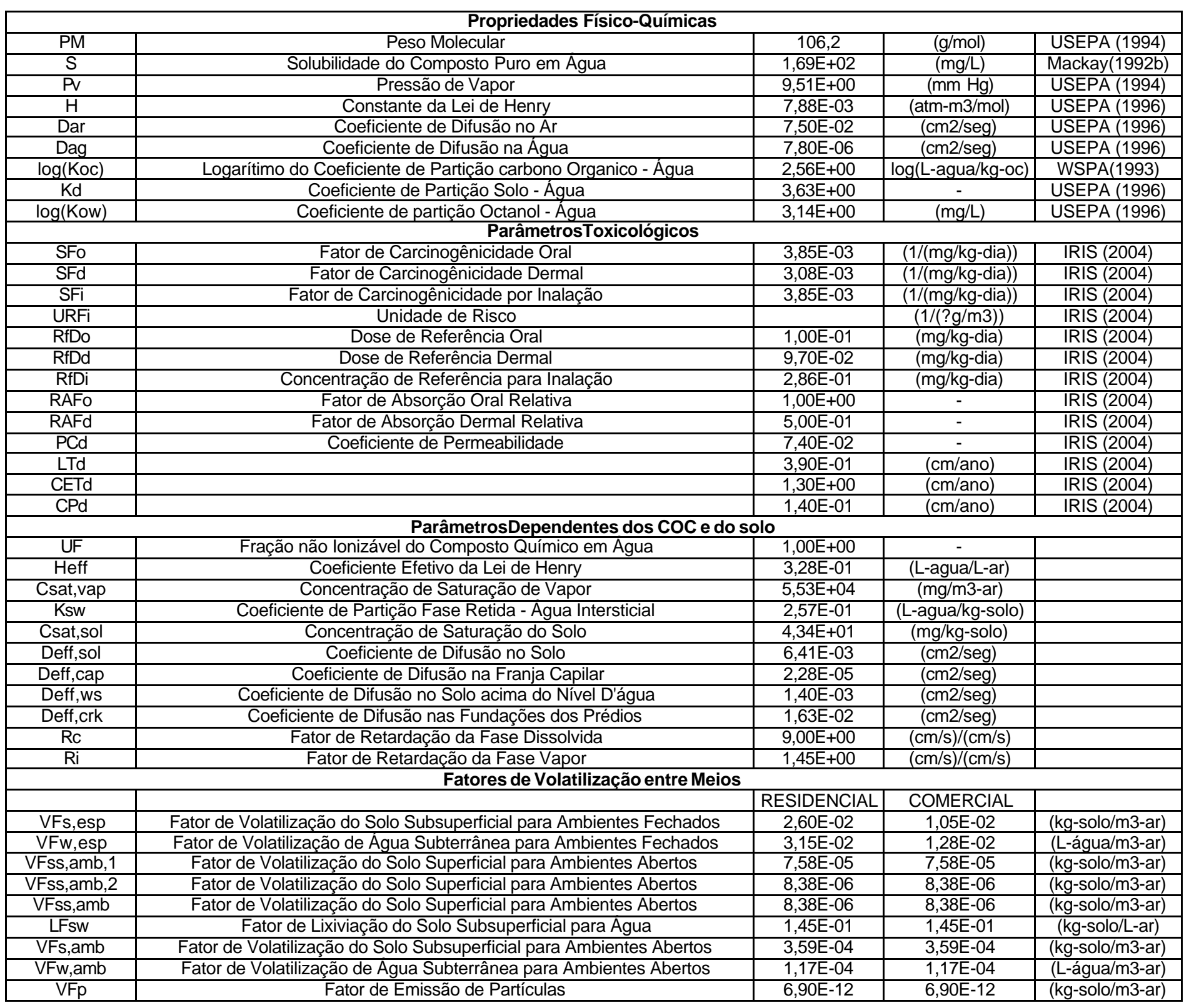




\begin{tabular}{|l|c|}
\hline NOME: & TOLUENO \\
\hline CAS RN: & $108-88-3$ \\
\hline FORMULA: & C7H8 \\
\hline
\end{tabular}

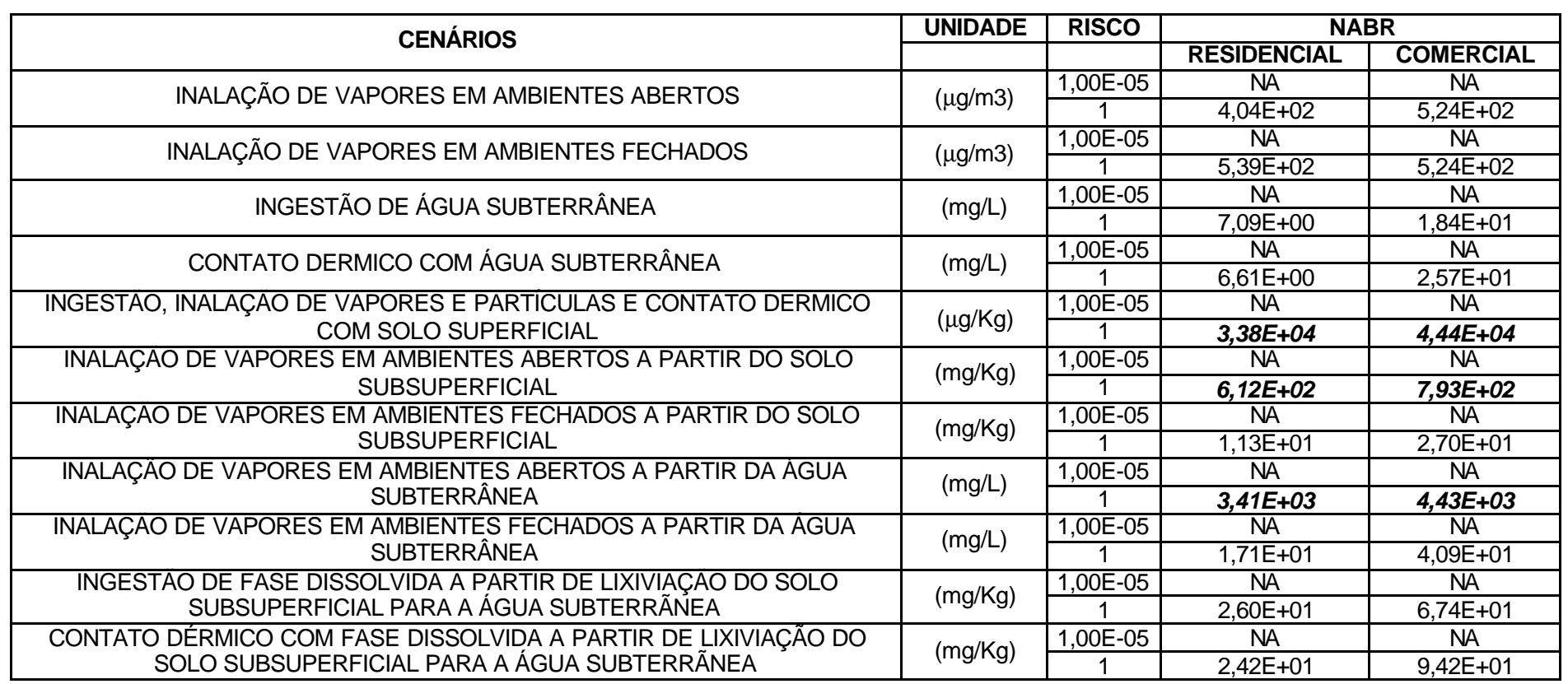

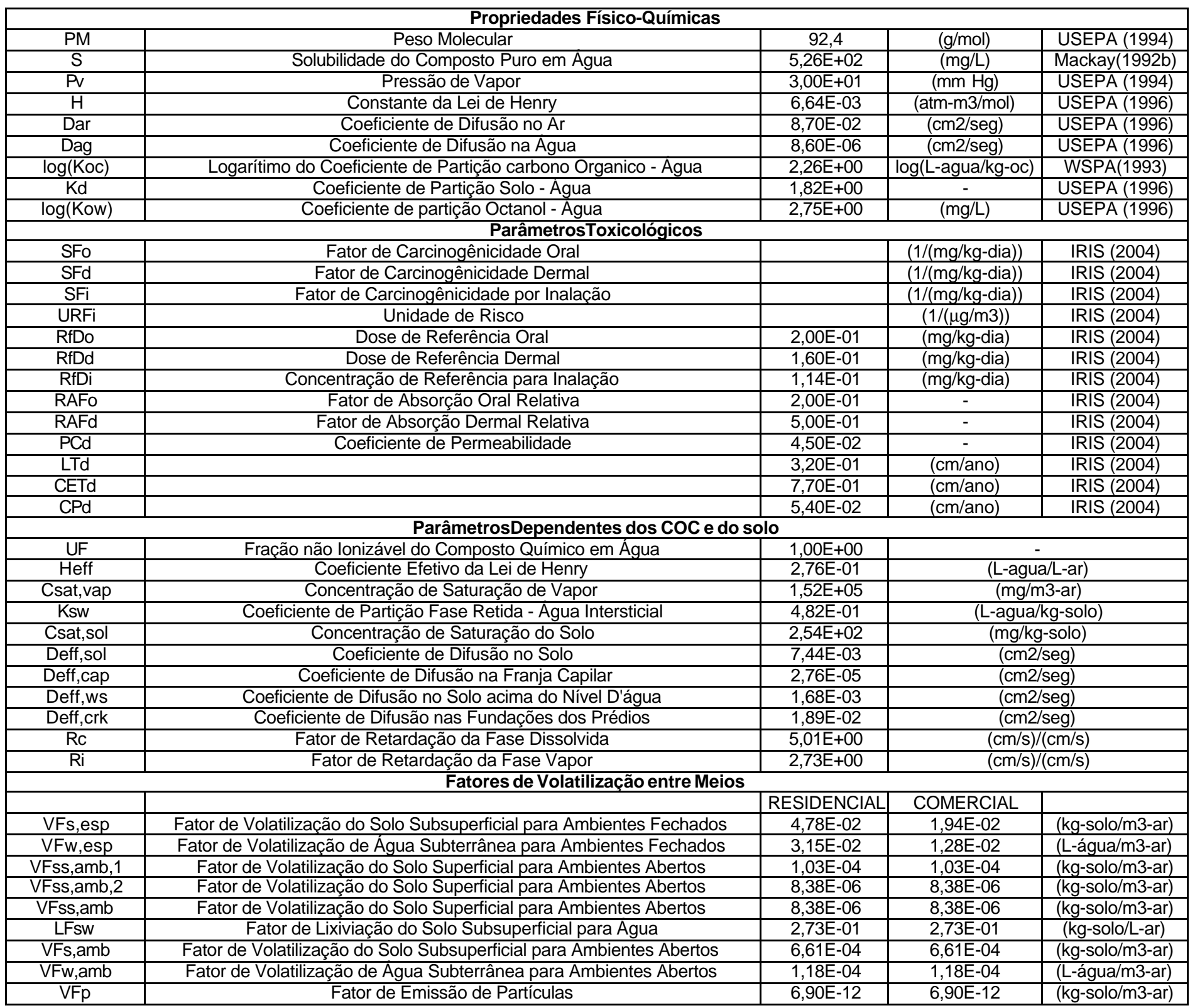




\begin{tabular}{|l|c|}
\hline NOME: & XILENOS (TOTAIS) \\
\hline CAS RN: & $1330-20-7$ \\
\hline FORMULA: & C8H10 \\
\hline
\end{tabular}

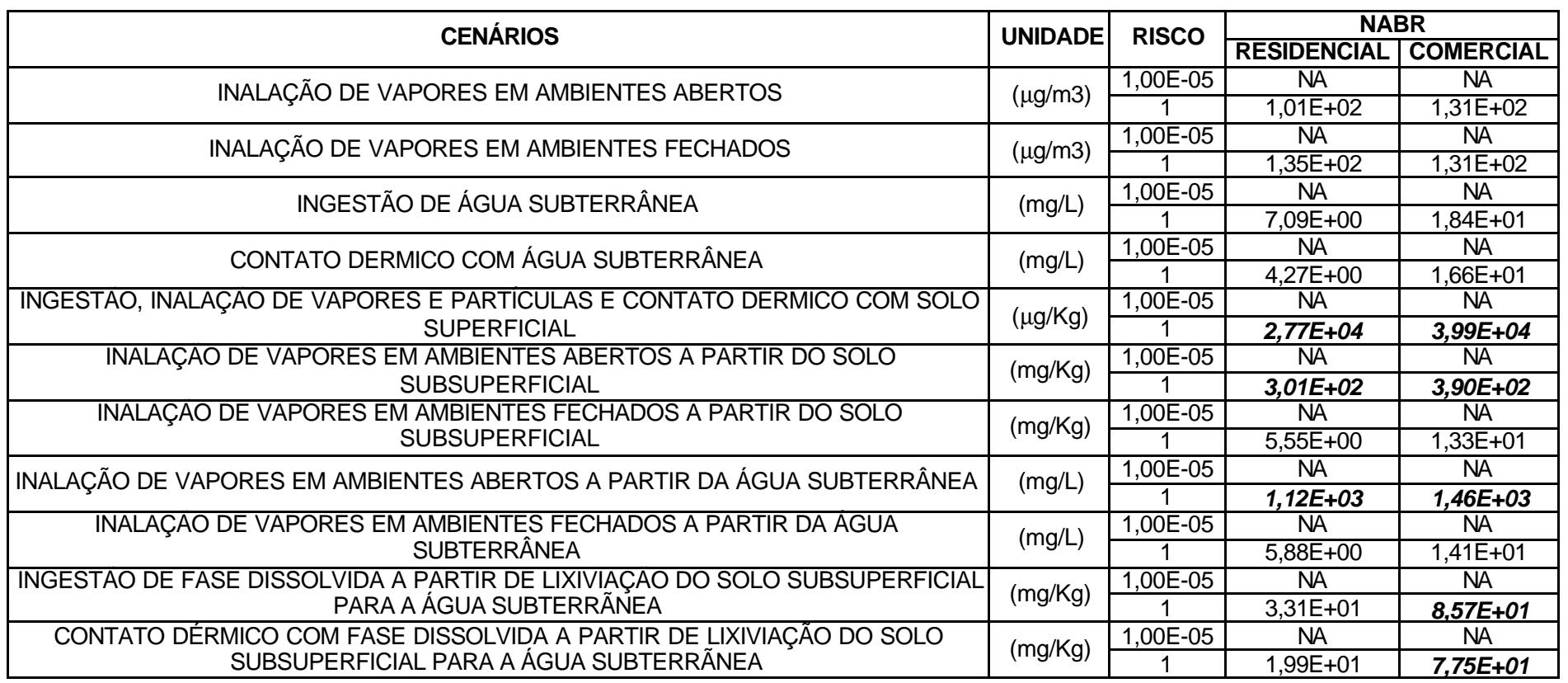

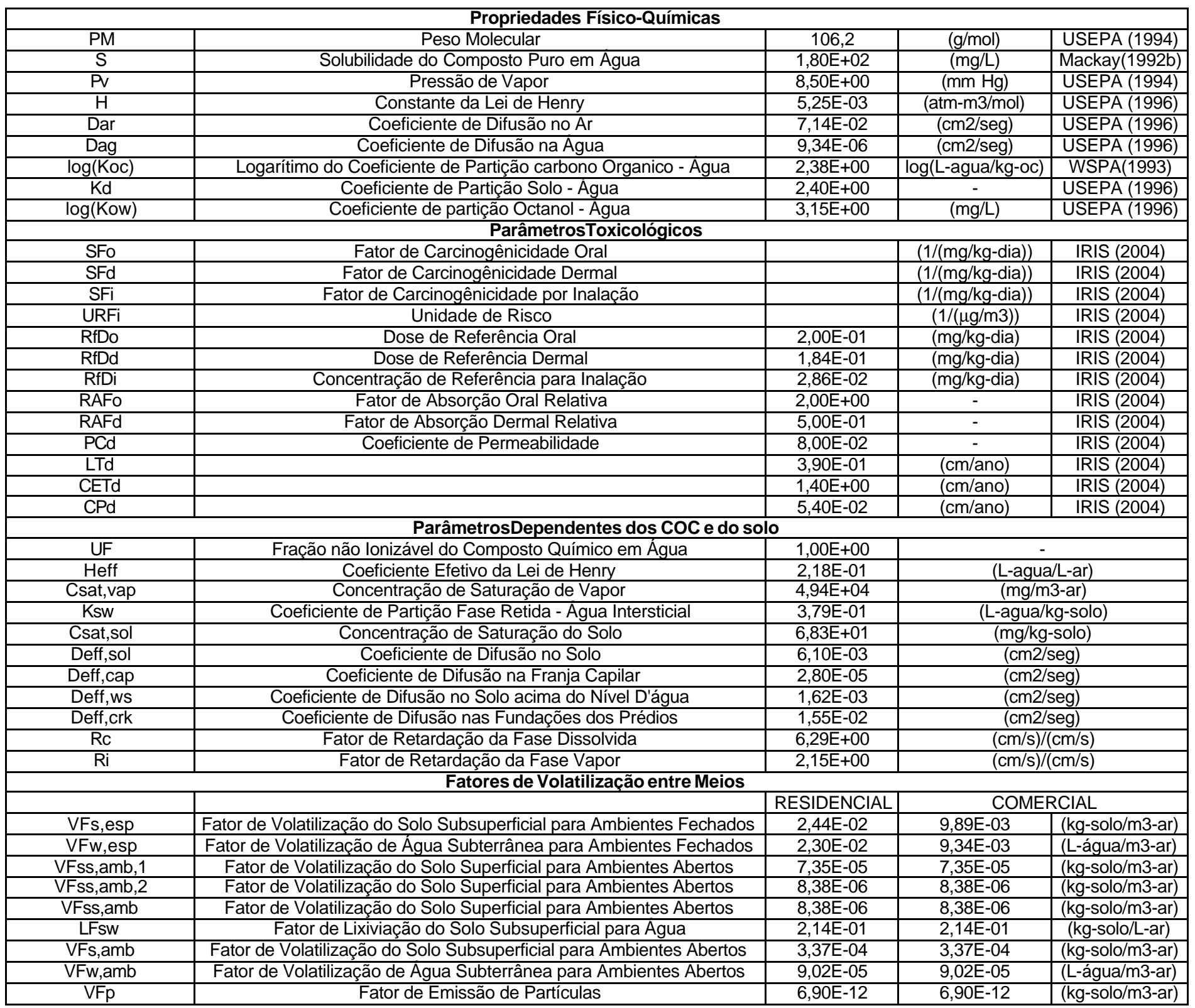




\begin{tabular}{|l|c|}
\hline NOME: & ACENAFTALENO \\
\hline CAS RN: & $208-96-8$ \\
\hline FORMULA: & C12H8 \\
\hline
\end{tabular}

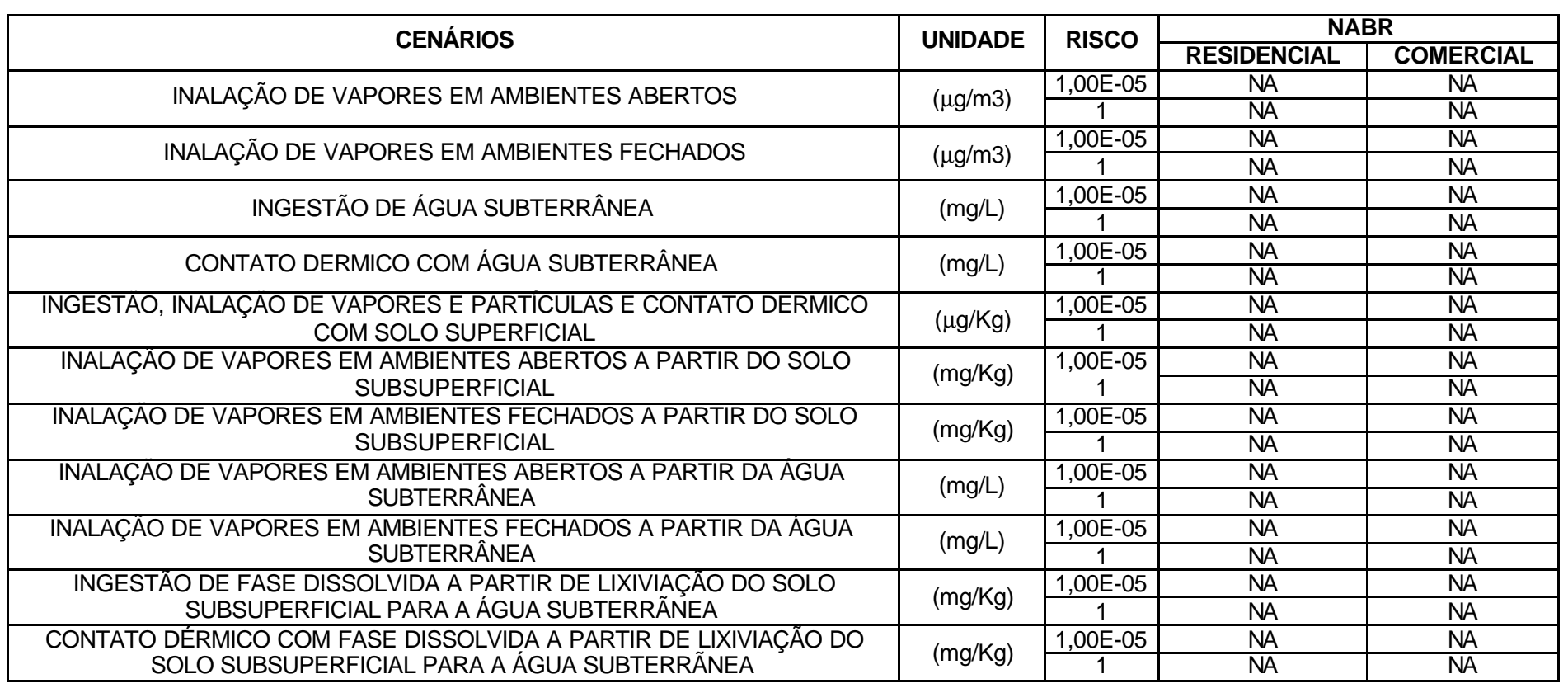

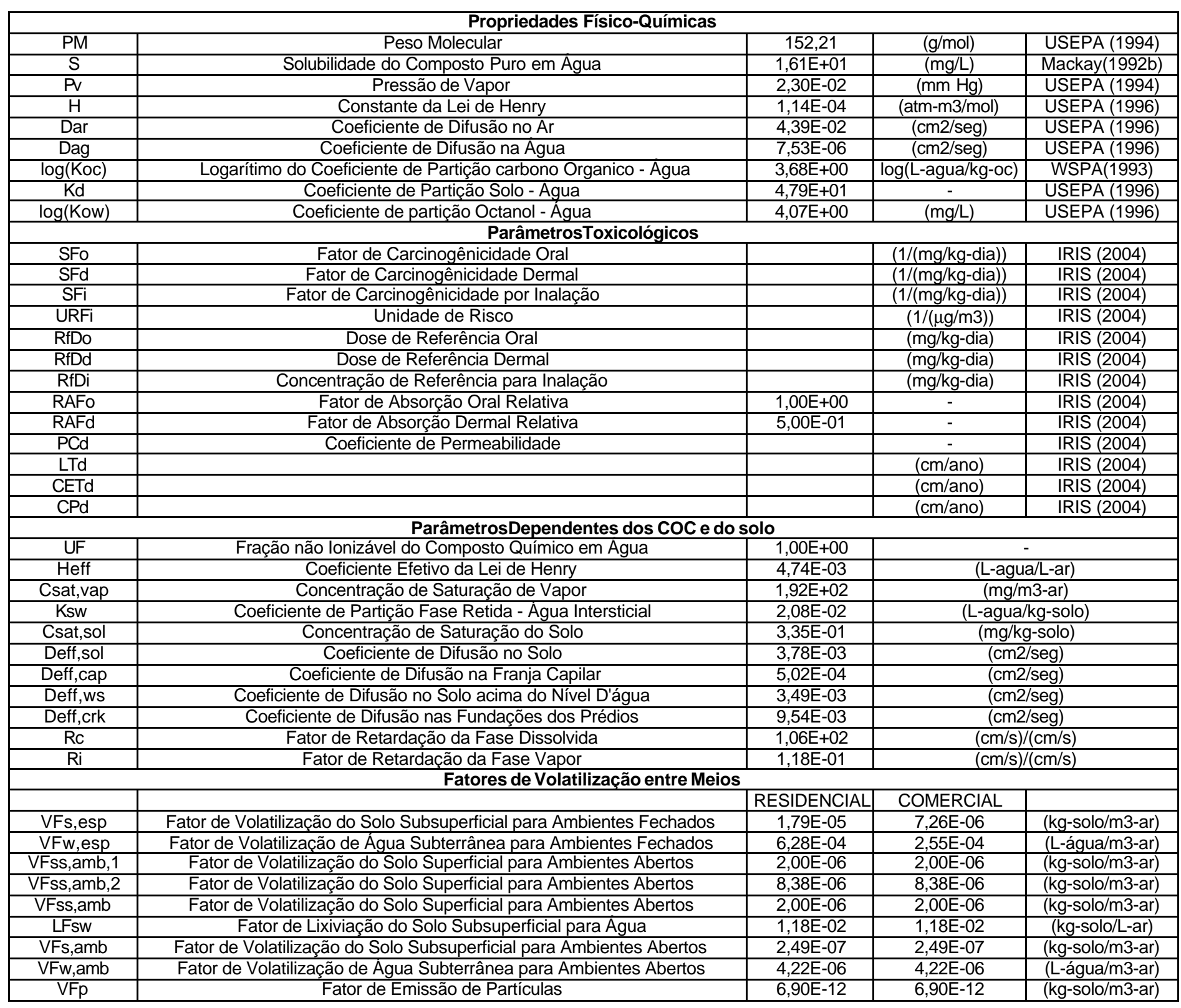




\begin{tabular}{|l|c|}
\hline NOME: & ACENAFTENO \\
\hline CAS RN: & $83-32-9$ \\
\hline FÓRMULA: & C12H10 \\
\hline
\end{tabular}

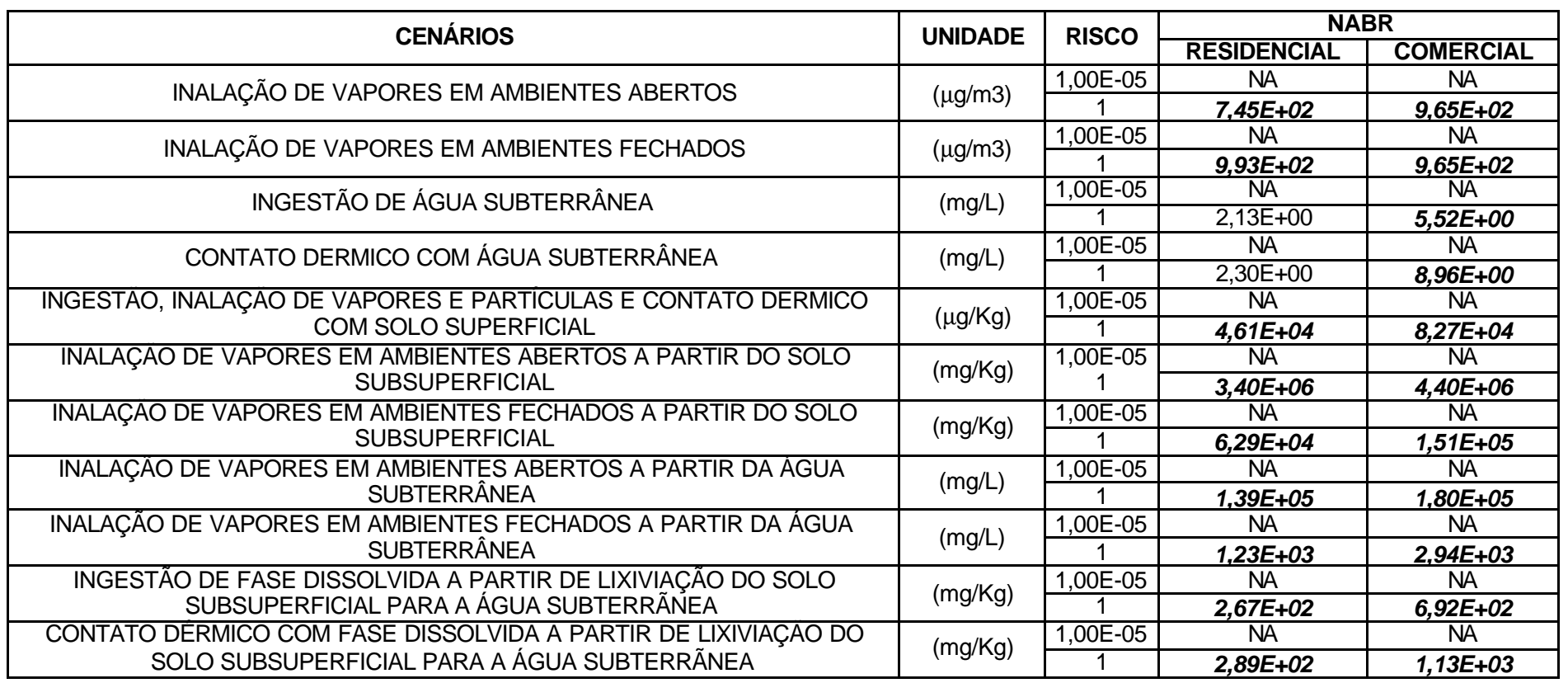

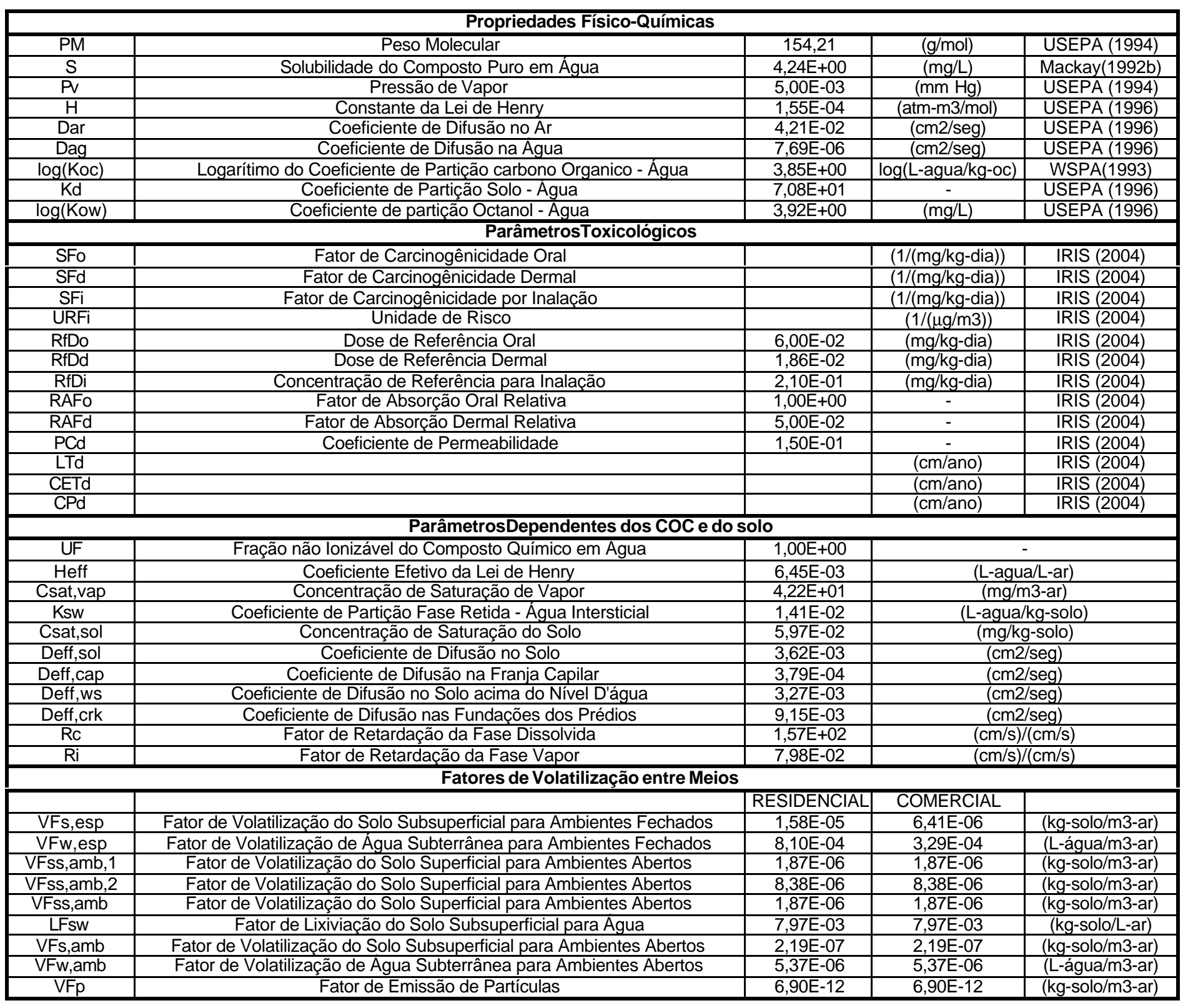




\begin{tabular}{|l|c|}
\hline NOME: & ANTRACENO \\
\hline CAS RN: & $120-12-7$ \\
\hline FÓRMULA: & C14H10 \\
\hline
\end{tabular}

\begin{tabular}{|c|c|c|c|c|}
\hline \multirow{2}{*}{ CENÁRIOS } & \multirow{2}{*}{ UNIDADE } & \multirow{2}{*}{ RISCO } & \multicolumn{2}{|c|}{ NABR } \\
\hline & & & RESIDENCIAL & COMERCIAL \\
\hline \multirow{2}{*}{ INALAÇÃO DE VAPORES EM AMBIENTES ABERTOS } & \multirow{2}{*}{$(\mu \mathrm{g} / \mathrm{m} 3)$} & $1,00 \mathrm{E}-05$ & $\overline{N A}$ & NA \\
\hline & & 1 & $3,72 E+03$ & $4,83 E+03$ \\
\hline \multirow{2}{*}{ INALAÇÃO DE VAPORES EM AMBIENTES FECHADOS } & \multirow{2}{*}{$(\mu \mathrm{g} / \mathrm{m} 3)$} & $1,00 \mathrm{E}-05$ & $\mathrm{NA}$ & $\mathrm{NA}$ \\
\hline & & 1 & $4,96 E+03$ & $4,83 E+03$ \\
\hline \multirow{2}{*}{ INGESTÃO DE ÁGUA SUBTERRÂNEA } & \multirow{2}{*}{$(\mathrm{mg} / \mathrm{L})$} & $1,00 \mathrm{E}-05$ & NA & $\mathrm{NA}$ \\
\hline & & 1 & $1,06 E+01$ & $2,76 E+01$ \\
\hline \multirow{2}{*}{ CONTATO DERMICO COM ÁGUA SUBTERRÂNEA } & \multirow{2}{*}{$(\mathrm{mg} / \mathrm{L})$} & $1,00 \mathrm{E}-05$ & NA & $\mathrm{NA}$ \\
\hline & & 1 & $1,93 E+01$ & $7,49 E+01$ \\
\hline \multirow{2}{*}{$\begin{array}{c}\text { INGESTAO, INALAÇAO DE VAPORES E PARTICULAS E CONTATO DERMICO } \\
\text { COM SOLO SUPERFICIAL }\end{array}$} & \multirow[b]{2}{*}{$(\mu \mathrm{g} / \mathrm{Kg})$} & $1,00 \mathrm{E}-05$ & $\mathrm{NA}$ & $\mathrm{NA}$ \\
\hline & & 1 & $2,30 E+05$ & $4,14 E+05$ \\
\hline \multirow{2}{*}{$\begin{array}{c}\text { INALAÇAO DE VAPORES EM AMBIENTES ABERTOS A PARTIR DO SOLO } \\
\text { SUBSUPERFICIAL }\end{array}$} & \multirow{2}{*}{$(\mathrm{mg} / \mathrm{Kg})$} & $1,00 \mathrm{E}-05$ & NA & $\overline{N A}$ \\
\hline & & 1 & $2,16 E+08$ & $2,80 E+08$ \\
\hline \multirow{2}{*}{$\begin{array}{c}\text { INALAÇÄO DE VAPORES EM AMBIENTES FECHADOS A PARTIR DO SOLO } \\
\text { SUBSUPERFICIAL }\end{array}$} & \multirow{2}{*}{$(\mathrm{mg} / \mathrm{Kg})$} & 1,00E-05 & $\mathrm{NA}$ & $\mathrm{NA}$ \\
\hline & & 1 & $4,04 E+06$ & $9,67 E+06$ \\
\hline \multirow{2}{*}{$\begin{array}{c}\text { INALAÇAO DE VAPORES EM AMBIENTES ABERTOS A PARTIR DA AGUA } \\
\text { SUBTERRÂNEA }\end{array}$} & \multirow{2}{*}{$(\mathrm{mg} / \mathrm{L})$} & $1,00 \mathrm{E}-05$ & NA & NA \\
\hline & & 1 & $1,97 E+06$ & $2,55 E+06$ \\
\hline \multirow{2}{*}{$\begin{array}{l}\text { INALAÇÃO DE VAPORES EM AMBIENTES FECHADOS A PARTIR DA ÁGUA } \\
\text { SUBTERRÂNEA }\end{array}$} & \multirow{2}{*}{$(\mathrm{mg} / \mathrm{L})$} & 1,00E-05 & NA & NA \\
\hline & & 1 & $1,83 E+04$ & $4,38 E+04$ \\
\hline \multirow{2}{*}{$\begin{array}{c}\text { INGESTÃO DE FASE DISSOLVIDA A PARTIR DE LIXIVIAÇÃO DO SOLO } \\
\text { SUBSUPERFICIAL PARA A ÁGUA SUBTERRÃNEA }\end{array}$} & \multirow{2}{*}{$(\mathrm{mg} / \mathrm{Kg})$} & 1,00E-05 & $\mathrm{NA}$ & $\mathrm{NA}$ \\
\hline & & 1 & $5,56 E+03$ & $1,44 E+04$ \\
\hline \multirow{2}{*}{$\begin{array}{c}\text { CONTATO DERMICO COM FASE DISSOLVIDA A PARTIR DE LIXIVIAÇAO DO } \\
\text { SOLO SUBSUPERFICIAL PARA A ÁGUA SUBTERRÃNEA }\end{array}$} & \multirow{2}{*}{$(\mathrm{mg} / \mathrm{Kg})$} & 1,00E-05 & $\mathrm{NA}$ & $\mathrm{NA}$ \\
\hline & & 1 & $1,01 E+04$ & $3,91 E+04$ \\
\hline
\end{tabular}

\begin{tabular}{|c|c|c|c|c|}
\hline \multicolumn{5}{|c|}{ Propriedades Físico-Químicas } \\
\hline PM & Peso Molecular & 178,23 & $(\mathrm{~g} / \mathrm{mol})$ & USEPA (1994) \\
\hline $\mathrm{S}$ & Solubilidade do Composto Puro em Agua & $4,50 \mathrm{E}-02$ & $(\mathrm{mg} / \mathrm{L})$ & Mackay(1992b) \\
\hline $\mathrm{PV}$ & Pressão de Vapor & $2,03 \mathrm{E}-03$ & $(\mathrm{~mm} \mathrm{Hg})$ & USEPA (1994) \\
\hline $\mathrm{H}$ & Constante da Lei de Henry & $6,50 \mathrm{E}-05$ & (atm-m3/mol) & USEPA (1996) \\
\hline Dar & Coeficiente de Difusão no $\mathrm{Ar}$ & $3,24 \mathrm{E}-02$ & (cm2/seg) & USEPA (1996) \\
\hline Dag & Coeficiente de Difusão na Água & 7,74E-06 & $(\mathrm{cm} 2 / \mathrm{seg})$ & USEPA (1996) \\
\hline $\log (\mathrm{Koc})$ & Logarítimo do Coeficiente de Partição carbono Organico - Água & $4,47 \mathrm{E}+00$ & $\log (\mathrm{L}-\mathrm{agua} / \mathrm{kg}-\mathrm{oc})$ & WSPA(1993) \\
\hline Kd & Coeficiente de Partição Solo - Água & $2,95 \mathrm{E}+02$ & - & USEPA (1996) \\
\hline $\log ($ Kow $)$ & Coeficiente de partição Octanol - Agua & $4,55 \mathrm{E}+00$ & $(\mathrm{mg} / \mathrm{L})$ & USEPA (1996) \\
\hline \multicolumn{5}{|c|}{ ParâmetrosToxicológicos } \\
\hline SFo & Fator de Carcinogênicidade Oral & & $(1 /(\mathrm{mg} / \mathrm{kg}-\mathrm{dia}))$ & IRIS (2004) \\
\hline SFd & Fator de Carcinogênicidade Dermal & & $(1 /(\mathrm{mg} / \mathrm{kg}-\mathrm{dia}))$ & IRIS (2004) \\
\hline SFi & Fator de Carcinogênicidade por Inalação & & $(1 /(\mathrm{mg} / \mathrm{kg}-\mathrm{dia}))$ & IRIS (2004) \\
\hline URFi & Unidade de Risco & & $(1 /(\mu \mathrm{g} / \mathrm{m} 3))$ & IRIS (2004) \\
\hline RfDo & Dose de Referência Oral & $3,00 \mathrm{E}-01$ & (mg/kg-dia) & IRIS (2004) \\
\hline $\mathrm{RfDd}$ & Dose de Referência Dermal & $2,28 \mathrm{E}-01$ & (mg/kg-dia) & IRIS (2004) \\
\hline RfDi & Concentração de Referência para Inalação & $1,05 \mathrm{E}+00$ & (mg/kg-dia) & IRIS (2004) \\
\hline RAFo & Fator de Absorção Oral Relativa & $1,00 \mathrm{E}+00$ & 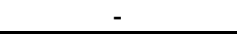 & IRIS (2004) \\
\hline RAFd & Fator de Absorção Dermal Relativa & $5,00 \mathrm{E}-02$ & - & IRIS (2004) \\
\hline PCd & Coeficiente de Permeabilidade & $2,20 \mathrm{E}-01$ & - & IRIS (2004) \\
\hline LTd & & & (cm/ano) & IRIS (2004) \\
\hline CETd & & & (cm/ano) & IRIS (2004) \\
\hline $\mathrm{CPd}$ & & & (cm/ano) & IRIS (2004) \\
\hline \multicolumn{5}{|c|}{ ParâmetrosDependentes dos COC e do solo } \\
\hline UF & Fração não lonizável do Composto Químico em Agua & $1,00 \mathrm{E}+00$ & & \\
\hline Heff & Coeficiente Efetivo da Lei de Henry & $2,70 \mathrm{E}-03$ & \multicolumn{2}{|c|}{ (L-agua/L-ar) } \\
\hline Csat,vap & Concentração de Saturação de Vapor & $1,98 \mathrm{E}+01$ & \multicolumn{2}{|c|}{ (mg/m3-ar) } \\
\hline Ksw & Coeficiente de Partição Fase Retida - Agua Intersticial & $3,39 \mathrm{E}-03$ & \multicolumn{2}{|c|}{ (L-agua/kg-solo) } \\
\hline Csat,sol & Concentração de Saturação do Solo & 1,52E-04 & \multicolumn{2}{|c|}{ (mg/kg-solo) } \\
\hline Deff,sol & Coeficiente de Difusão no Solo & $2,82 \mathrm{E}-03$ & \multicolumn{2}{|c|}{$(\mathrm{cm} 2 / \mathrm{seg})$} \\
\hline Deff,cap & Coeficiente de Difusão na Franja Capilar & $8,95 \mathrm{E}-04$ & \multicolumn{2}{|c|}{$(\mathrm{cm} 2 / \mathrm{seg})$} \\
\hline Deff,ws & Coeficiente de Difusão no Solo acima do Nível D'água & $2,75 \mathrm{E}-03$ & \multicolumn{2}{|c|}{$(\mathrm{cm} 2 / \mathrm{seg})$} \\
\hline Deff,crk & Coeficiente de Difusão nas Fundações dos Prédios & $7,05 \mathrm{E}-03$ & \multicolumn{2}{|c|}{$(\mathrm{cm} 2 / \mathrm{seg})$} \\
\hline Rc & Fator de Retardação da Fase Dissolvida & $6,51 \mathrm{E}+02$ & \multirow{2}{*}{\multicolumn{2}{|c|}{$\frac{(\mathrm{cm} / \mathrm{s}) /(\mathrm{cm} / \mathrm{s})}{(\mathrm{cm} / \mathrm{s}) /(\mathrm{cm} / \mathrm{s})}$}} \\
\hline $\mathrm{Ri}$ & Fator de Retardação da Fase Vapor & 1,92E-02 & & \\
\hline \multicolumn{5}{|c|}{ Fatores de Volatilização entre Meios } \\
\hline & & RESIDENCIAL & COMERCIAL & \\
\hline VFs,esp & Fator de Volatilização do Solo Subsuperficial para Ambientes Fechados & $1,23 \mathrm{E}-06$ & 4,99E-07 & (kg-solo/m3-ar) \\
\hline VFw,esp & Fator de Volatilização de Água Subterrânea para Ambientes Fechados & $2,72 \mathrm{E}-04$ & $1,10 \mathrm{E}-04$ & (L-água/m3-ar) \\
\hline VFss,amb,1 & Fator de Volatilização do Solo Superficial para Ambientes Abertos & $5,25 \mathrm{E}-07$ & $5,25 \mathrm{E}-07$ & (kg-solo/m3-ar) \\
\hline VFss,amb,2 & Fator de Volatilização do Solo Superficial para Ambientes Abertos & $8,38 \mathrm{E}-06$ & $8,38 \mathrm{E}-06$ & (kg-solo/m3-ar) \\
\hline VFss,amb & Fator de Volatilização do Solo Superficial para Ambientes Abertos & $5,25 \mathrm{E}-07$ & $5,25 \mathrm{E}-07$ & (kg-solo/m3-ar) \\
\hline LFsw & Fator de Lixiviação do Solo Subsuperficial para Agua & $1,91 \mathrm{E}-03$ & $1,91 \mathrm{E}-03$ & (kg-solo/L-ar) \\
\hline VFs,amb & Fator de Volatilização do Solo Subsuperficial para Ambientes Abertos & $1,72 \mathrm{E}-08$ & $1,72 \mathrm{E}-08$ & (kg-solo/m3-ar) \\
\hline VFw,amb & Fator de Volatilização de Agua Subterrânea para Ambientes Abertos & 1,89E-06 & 1,89E-06 & (L-água/m3-ar) \\
\hline VFp & Fator de Emissão de Partículas & $6,90 \mathrm{E}-12$ & $6,90 \mathrm{E}-12$ & (kg-solo/m3-ar) \\
\hline
\end{tabular}




\begin{tabular}{|l|c|}
\hline NOME: & BENZO(a)ANTRACENO \\
\hline CAS RN: & $56-55-3$ \\
\hline FÓRMULA: & C18H12 \\
\hline
\end{tabular}

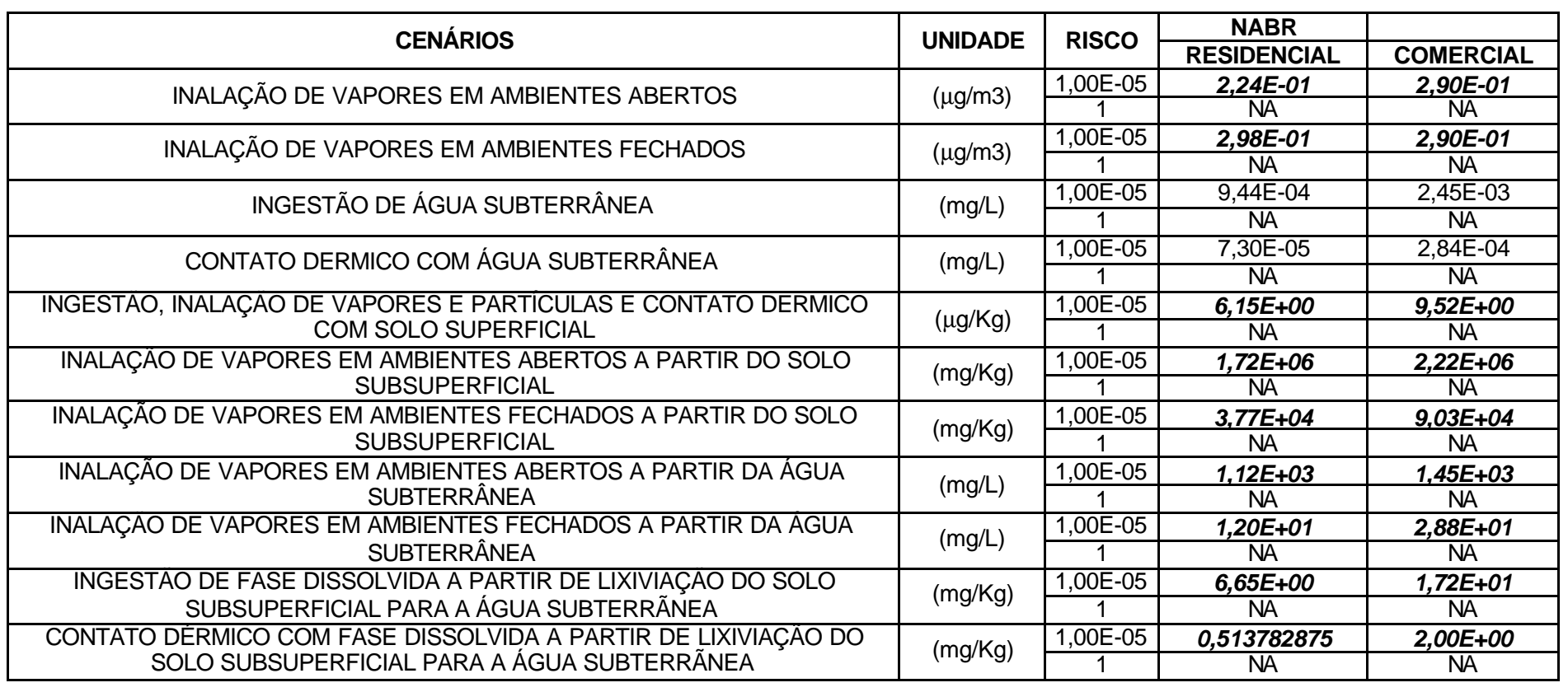

\begin{tabular}{|c|c|c|c|c|}
\hline \multicolumn{5}{|c|}{ Propriedades Físico-Químicas } \\
\hline PM & Peso Molecular & 228,3 & $(\mathrm{~g} / \mathrm{mol})$ & USEPA (1994) \\
\hline $\mathrm{S}$ & Solubilidade do Composto Puro em Agua & $9,40 \mathrm{E}-03$ & $(\mathrm{mg} / \mathrm{L})$ & Mackay(1992b) \\
\hline $\mathrm{PV}$ & Pressão de Vapor & $4,64 \mathrm{E}-07$ & $(\mathrm{~mm} \mathrm{Hg})$ & USEPA (1994) \\
\hline $\mathrm{H}$ & Constante da Lei de Henry & $3,35 \mathrm{E}-06$ & (atm-m3/mol) & USEPA (1996) \\
\hline Dar & Coeficiente de Difusão no $\mathrm{Ar}$ & $5,10 \mathrm{E}-02$ & (cm2/seg) & USEPA (1996) \\
\hline Dag & Coeficiente de Difusão na Água & $9,00 \mathrm{E}-06$ & $(\mathrm{~cm} 2 / \mathrm{seg})$ & USEPA (1996) \\
\hline $\log (\mathrm{Koc})$ & Logarítimo do Coeficiente de Partição carbono Organico - Agua & $5,60 \mathrm{E}+00$ & $\mid \log (\mathrm{L}$-agua/kg-oc) & WSPA(1993) \\
\hline Kd & Coeficiente de Partição Solo - Agua & $3,98 \mathrm{E}+03$ & - & USEPA (1996) \\
\hline $\log (\mathrm{Kow})$ & Coeficiente de partição Octanol - Água & $5,70 \mathrm{E}+00$ & $(\mathrm{mg} / \mathrm{L})$ & USEPA (1996) \\
\hline \multicolumn{5}{|c|}{ ParâmetrosToxicológicos } \\
\hline SFo & Fator de Carcinogênicidade Oral & 7,30E-01 & $(1 /(\mathrm{mg} / \mathrm{kg}-\mathrm{dia}))$ & IRIS (2004) \\
\hline SFd & Fator de Carcinogênicidade Dermal & $2,35 \mathrm{E}+00$ & $(1 /(\mathrm{mg} / \mathrm{kg}-\mathrm{dia}))$ & IRIS (2004) \\
\hline SFi & Fator de Carcinogênicidade por Inalação & $3,08 \mathrm{E}-01$ & $(1 /(\mathrm{mg} / \mathrm{kg}-\mathrm{dia}))$ & IRIS (2004) \\
\hline URFi & Unidade de Risco & $8,80 \mathrm{E}-05$ & $(1 /(\mu \mathrm{g} / \mathrm{m} 3))$ & IRIS (2004) \\
\hline RfDo & Dose de Referência Oral & & (mg/kg-dia) & IRIS (2004) \\
\hline RfDd & Dose de Referência Dermal & & (mg/kg-dia) & IRIS (2004) \\
\hline RfDi & Concentração de Referência para Inalação & $1,00 \mathrm{E}+00$ & (mg/kg-dia) & IRIS (2004) \\
\hline RAFo & Fator de Absorção Oral Relativa & $1,00 \mathrm{E}+00$ & - & IRIS (2004) \\
\hline RAFd & Fator de Absorção Dermal Relativa & $1,30 \mathrm{E}-01$ & - & IRIS (2004) \\
\hline PCd & Coeficiente de Permeabilidade & $8,10 \mathrm{E}-01$ & - & IRIS (2004) \\
\hline LTd & & & (cm/ano) & IRIS (2004) \\
\hline CETd & & & $(\mathrm{cm} / \mathrm{ano})$ & IRIS (2004) \\
\hline $\mathrm{CPd}$ & & & (cm/ano) & IRIS (2004) \\
\hline \multicolumn{5}{|c|}{ ParâmetrosDependentes dos COC e do solo } \\
\hline$\overline{U F}$ & Fração não lonizável do Composto Químico em Agua & $\overline{1,00 \mathrm{E}+00}$ & \multirow{2}{*}{\multicolumn{2}{|c|}{ (L-agua/L-ar) }} \\
\hline Heff & Coeficiente Efetivo da Lei de Henry & $1,39 \mathrm{E}-04$ & & \\
\hline Csat,vap & Concentração de Saturação de Vapor & $5,80 \mathrm{E}-03$ & \multirow{2}{*}{\multicolumn{2}{|c|}{$\frac{\text { (mg/m3-ar) }}{\text { (L-agua/kg-solo) }}$}} \\
\hline Ksw & Coeficiente de Partição Fase Retida - Agua Intersticial & $2,51 \mathrm{E}-04$ & & \\
\hline Csat,sol & Concentração de Saturação do Solo & $2,36 \mathrm{E}-06$ & \multicolumn{2}{|c|}{$\frac{(\text { L-agua } / \mathrm{kg} \text {-solo) }}{(\mathrm{mg} / \mathrm{kg} \text {-solo })}$} \\
\hline Deff,sol & Coeficiente de Difusão no Solo & $5,59 \mathrm{E}-03$ & \multicolumn{2}{|c|}{ (cm2/seg) } \\
\hline Deff,cap & Coeficiente de Difusão na Franja Capilar & $2,01 \mathrm{E}-02$ & \multicolumn{2}{|c|}{$(\mathrm{cm} 2 / \mathrm{seg})$} \\
\hline Deff,ws & Coeficiente de Difusão no Solo acima do Nível D'água & $5,64 \mathrm{E}-03$ & \multicolumn{2}{|c|}{$(\mathrm{cm} 2 / \mathrm{seg})$} \\
\hline Deff,crk & Coeficiente de Difusão nas Fundações dos Prédios & $1,14 \mathrm{E}-02$ & \multicolumn{2}{|c|}{$(\mathrm{cm} 2 / \mathrm{seg})$} \\
\hline $\mathrm{Rc}$ & Fator de Retardação da Fase Dissolvida & $8,77 \mathrm{E}+03$ & \multirow{2}{*}{\multicolumn{2}{|c|}{$\frac{(\mathrm{cm} / \mathrm{s}) /(\mathrm{cm} / \mathrm{s})}{(\mathrm{cm} / \mathrm{s}) /(\mathrm{cm} / \mathrm{s})}$}} \\
\hline $\mathrm{Ri}$ & Fator de Retardação da Fase Vapor & $1,42 \mathrm{E}-03$ & & \\
\hline \multicolumn{5}{|c|}{ Fatores de Volatilização entre Meios } \\
\hline & & RESIDENCIAL & COMERCIAL & \\
\hline VFs,esp & Fator de Volatilização do Solo Subsuperficial para Ambientes Fechados & 7,91E-09 & $3,21 \mathrm{E}-09$ & (kg-solo/m3-ar) \\
\hline VFw,esp & Fator de Volatilização de Agua Subterrânea para Ambientes Fechados & $2,48 \mathrm{E}-05$ & $1,01 \mathrm{E}-05$ & (L-água/m3-ar) \\
\hline VFss,amb,1 & Fator de Volatilização do Solo Superficial para Ambientes Abertos & $4,57 \mathrm{E}-08$ & $4,57 \mathrm{E}-08$ & (kg-solo/m3-ar) \\
\hline VFss,amb,2 & Fator de Volatilização do Solo Superficial para Ambientes Abertos & $8,38 \mathrm{E}-06$ & $8,38 \mathrm{E}-06$ & (kg-solo/m3-ar) \\
\hline VFss,amb & Fator de Volatilização do Solo Superficial para Ambientes Abertos & 4,57E-08 & 4,57E-08 & (kg-solo/m3-ar) \\
\hline LFsw & Fator de Lixiviação do Solo Subsuperficial para Água & $1,42 \mathrm{E}-04$ & $1,42 \mathrm{E}-04$ & (kg-solo/L-ar) \\
\hline VFs,amb & Fator de Volatilização do Solo Subsuperficial para Ambientes Abertos & $1,30 \mathrm{E}-10$ & $1,30 \mathrm{E}-10$ & (kg-solo/m3-ar) \\
\hline VFw,amb & Fator de Volatilização de Agua Subterrânea para Ambientes Abertos & $2,00 \mathrm{E}-07$ & $2,00 \mathrm{E}-07$ & (L-água/m3-ar) \\
\hline VFp & Fator de Emissão de Partículas & $6,90 \mathrm{E}-12$ & $6,90 \mathrm{E}-12$ & (kg-solo/m3-ar) \\
\hline
\end{tabular}




\section{CENÁRIOS}

INALAÇÃO DE VAPORES EM AMBIENTES ABERTOS

INALAÇÃO DE VAPORES EM AMBIENTES FECHADOS INGESTÃO DE ÁGUA SUBTERRÂNEA

CONTATO DERMICO COM ÁGUA SUBTERRÂNEA

INGESTAO, INALAÇAO DE VAPORES E PARTICULAS E CONTATO DERMICO COM SOLO SUPERFICIAL

INALAÇAO DE VAPORESEM AMBIENTES ABERTOS A PARTIR DO SOLO

SUBSUPERFICIAL

INALAÇAO DE VAPORES EM AMBIENTES FECHADOS A PARTIR DO SOLO SUBSUPERFICIAL

INALAÇÃO DE VAPORES EM AMBIENTES ABERTOS A PARTIR DA ÁGUA SUBTERRÂNEA

INALAÇÃO DE VAPORES EM AMBIENTES FECHADOS A PARTIR DA ÁGUA

SUBTERRÂNEA

INGESTAO DE FASE DISSOLVIDA A PARTIR DE LIXIVIAÇAO DO SOLO SUBSUPERFICIAL

PARA A ÁGUA SUBTERRÃNEA

CONTATO DERMICO COM FASE DISSOLVIDA A PARTIR DE LIXIVIAÇAO DO SOLO

SUBSUPERFICIAL PARA A ÁGUA SUBTERRÃNEA

\begin{tabular}{|c|c|c|c|}
\hline \multirow{2}{*}{ UNIDADE } & \multirow{2}{*}{ RISCO } & \multicolumn{2}{|c|}{ NABR } \\
\hline & & RESIDENCIAL & COMERCIAL \\
\hline \multirow{2}{*}{ (mg/m3) } & $1,00 \mathrm{E}-05$ & $9,44 E-03$ & $1,22 E-02$ \\
\hline & 1 & $\overline{N A}$ & $\mathrm{NA}$ \\
\hline \multirow{2}{*}{$(\mathrm{mg} / \mathrm{m} 3)$} & $1,00 \mathrm{E}-05$ & $1,26 E-02$ & $1,22 E-02$ \\
\hline & 1 & $\mathrm{NA}$ & NA \\
\hline \multirow{2}{*}{ (mg/L) } & $1,00 \mathrm{E}-05$ & 9,44E-05 & $2,45 E-04$ \\
\hline & 1 & NA & $\mathrm{NA}$ \\
\hline \multirow{2}{*}{$(\mathrm{mg} / \mathrm{L})$} & $1,00 \mathrm{E}-05$ & 4,92E-06 & 1,92E-05 \\
\hline & 1 & $\mathrm{NA}$ & $\mathrm{NA}$ \\
\hline \multirow{2}{*}{$(\mathrm{mg} / \mathrm{Kg})$} & $1,00 \mathrm{E}-05$ & $6,15 E-01$ & 9,52E-01 \\
\hline & 1 & $\mathrm{NA}$ & NA \\
\hline \multirow{2}{*}{$(\mathrm{mg} / \mathrm{Kg})$} & $1,00 \mathrm{E}-05$ & $4,22 E+05$ & $5,47 E+05$ \\
\hline & 1 & $\mathrm{NA}$ & $\overline{N A}$ \\
\hline \multirow{2}{*}{$(\mathrm{mg} / \mathrm{Kg})$} & 1,00E-05 & $1,26 E+04$ & $3,03 E+04$ \\
\hline & 1 & NA & NA \\
\hline \multirow{2}{*}{$(\mathrm{mg} / \mathrm{L})$} & 1,00E-05 & $1,07 E+02$ & $1,38 E+02$ \\
\hline & 1 & $\mathrm{NA}$ & NA \\
\hline \multirow{2}{*}{$(\mathrm{mg} / \mathrm{L})$} & 1,00E-05 & $1,48 E+00$ & $3,54 E+00$ \\
\hline & 1 & $\mathrm{NA}$ & NA \\
\hline \multirow{2}{*}{$(\mathrm{mg} / \mathrm{Kg})$} & $1,00 \mathrm{E}-05$ & $1,71 E+00$ & $4,43 E+00$ \\
\hline & 1 & $\overline{\mathrm{NA}}$ & $\overline{\mathrm{NA}}$ \\
\hline \multirow{2}{*}{$(\mathrm{mg} / \mathrm{Kg})$} & $1,00 \mathrm{E}-05$ & 8,91E-02 & $3,47 E-01$ \\
\hline & 1 & $\mathrm{NA}$ & $\mathrm{NA}$ \\
\hline
\end{tabular}

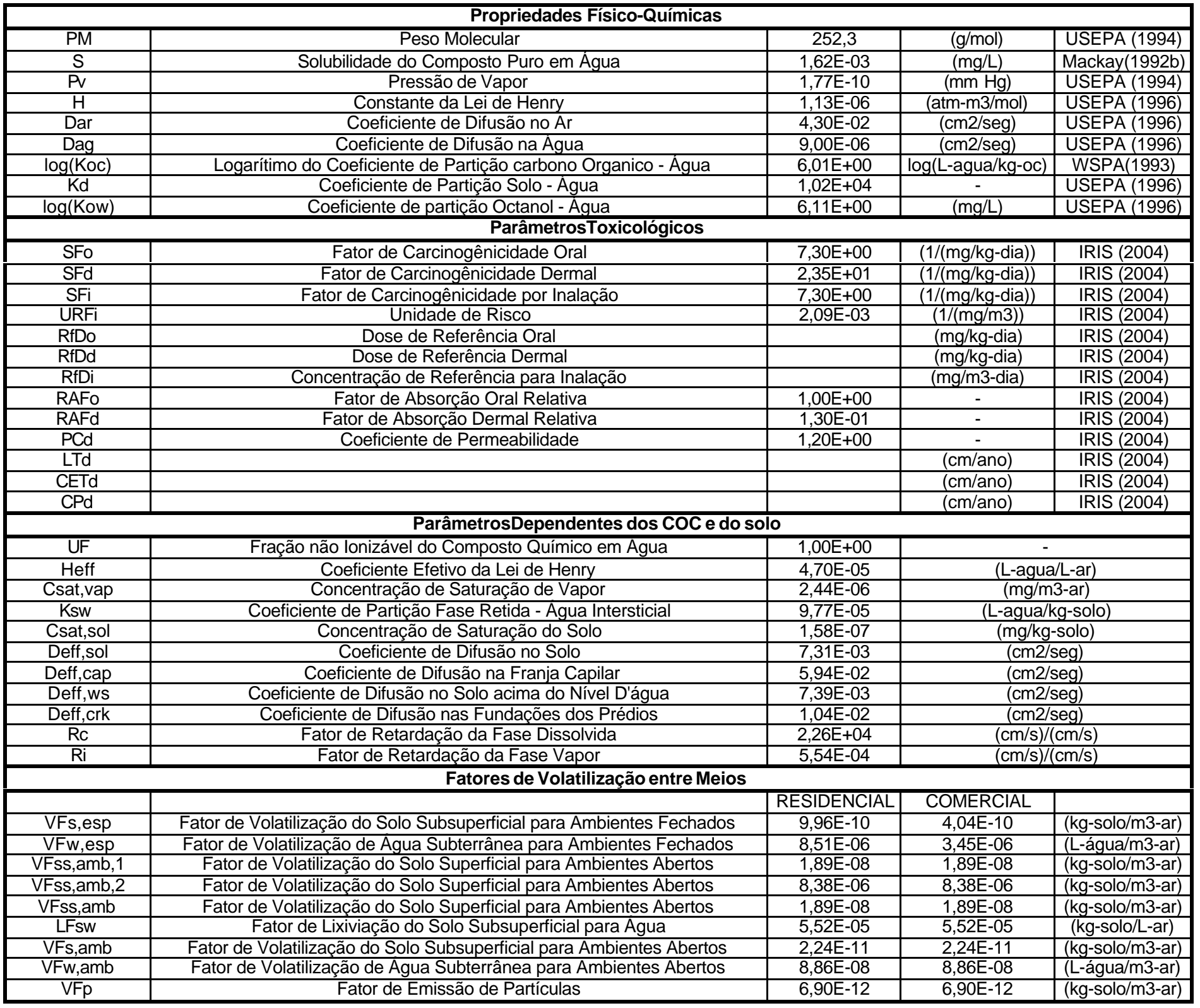




\begin{tabular}{|l|c|}
\hline NOME: & BENZO(b)FLUORANTENO \\
\hline CAS RN: & $205-99-2$ \\
\hline FÓRMULA: & C20H12 \\
\hline
\end{tabular}

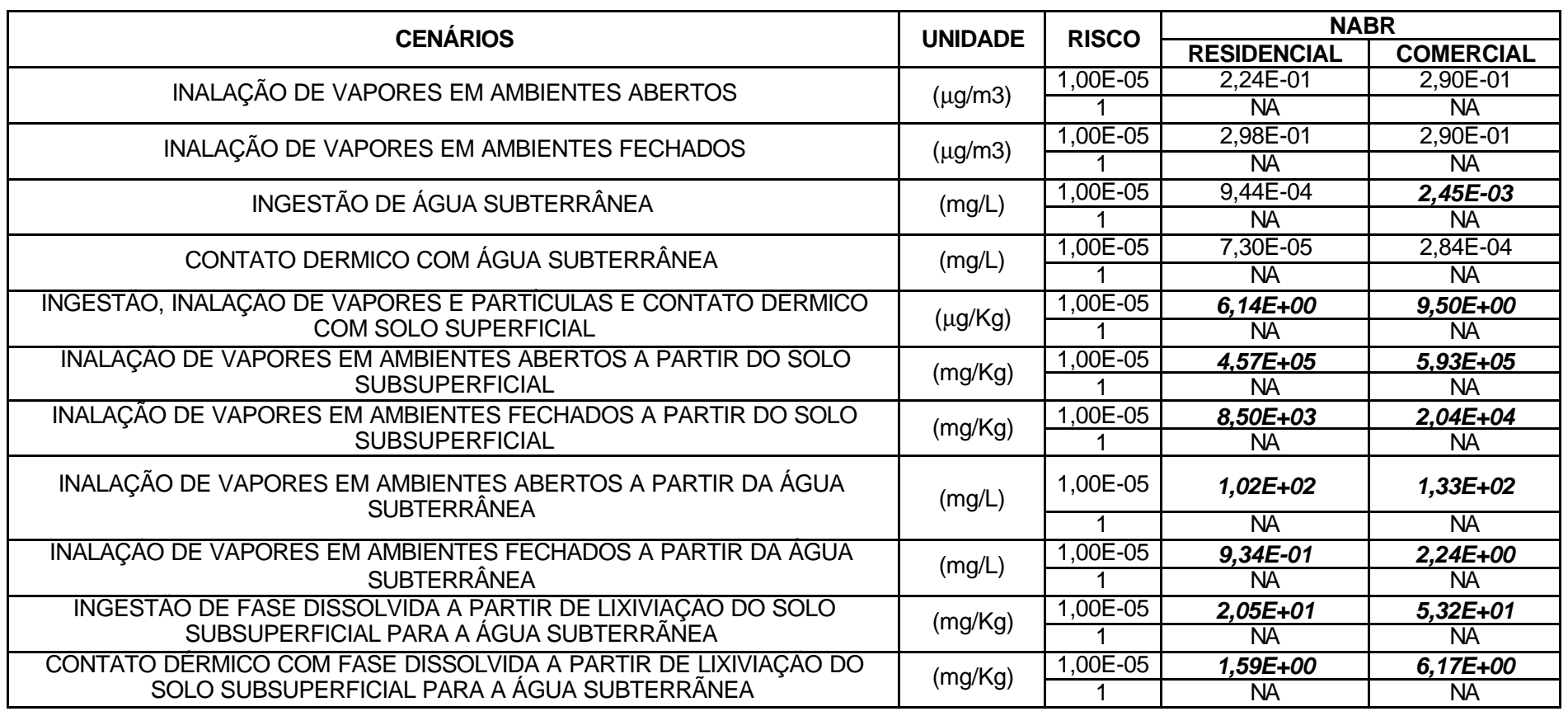

\begin{tabular}{|c|c|c|c|c|}
\hline \multicolumn{5}{|c|}{ Propriedades Físico-Químicas } \\
\hline $\mathrm{PM}$ & Peso Molecular & 252 & $(\mathrm{~g} / \mathrm{mol})$ & USEPA (1994) \\
\hline $\mathrm{S}$ & Solubilidade do Composto Puro em Água & 1,50E-03 & $(\mathrm{mg} / \mathrm{L})$ & Mackay(1992b) \\
\hline $\mathrm{PV}$ & Pressão de Vapor & $5,07 \mathrm{E}-05$ & $(\mathrm{~mm} \mathrm{Hg})$ & USEPA (1994) \\
\hline $\mathrm{H}$ & Constante da Lei de Henry & $1,11 \mathrm{E}-04$ & $(\mathrm{~atm}-\mathrm{m} 3 / \mathrm{mol})$ & USEPA (1996) \\
\hline Dar & Coeficiente de Difusão no Ar & $2,26 \mathrm{E}-02$ & (cm2/seg) & USEPA (1996) \\
\hline Dag & Coeficiente de Difusão na Água & 5,56E-06 & (cm2/seg) & USEPA (1996) \\
\hline $\log (\mathrm{Koc})$ & Logarítimo do Coeficiente de Partição carbono Organico - Água & $6,09 \mathrm{E}+00$ & $\log (\mathrm{L}-\mathrm{agua} / \mathrm{kg}-\mathrm{oc})$ & WSPA(1993) \\
\hline Kd & Coeficiente de Partição Solo - Agua & $1,23 \mathrm{E}+04$ & - & USEPA (1996) \\
\hline $\log ($ Kow $)$ & Coeficiente de partição Octanol - Agua & $6,20 \mathrm{E}+00$ & $(\mathrm{mg} / \mathrm{L})$ & USEPA (1996) \\
\hline \multicolumn{5}{|c|}{ ParâmetrosToxicológicos } \\
\hline SFo & Fator de Carcinogênicidade Oral & $7,30 \mathrm{E}-01$ & $(1 /(\mathrm{mg} / \mathrm{kg}-\mathrm{dia}))$ & IRIS (2004) \\
\hline SFd & Fator de Carcinogênicidade Dermal & $2,35 \mathrm{E}+00$ & $(1 /(\mathrm{mg} / \mathrm{kg}-\mathrm{dia}))$ & IRIS (2004) \\
\hline SFi & Fator de Carcinogênicidade por Inalação & $3,08 \mathrm{E}-01$ & $(1 /(\mathrm{mg} / \mathrm{kg}$-dia $))$ & IRIS (2004) \\
\hline URFi & Unidade de Risco & $8,80 \mathrm{E}-05$ & $(1 /(\mu \mathrm{g} / \mathrm{m} 3))$ & IRIS (2004) \\
\hline RfDo & Dose de Referência Oral & & (mg/kg-dia) & IRIS (2004) \\
\hline RfDd & Dose de Referência Dermal & & (mg/kg-dia) & IRIS (2004) \\
\hline RfDi & Concentração de Referência para Inalação & $1,00 \mathrm{E}+00$ & (mg/m3-dia) & IRIS (2004) \\
\hline RAFo & Fator de Absorção Oral Relativa & $1,00 \mathrm{E}+00$ & - & IRIS (2004) \\
\hline RAFd & Fator de Absorção Dermal Relativa & $1,30 \mathrm{E}-01$ & - & IRIS (2004) \\
\hline $\mathrm{PCd}$ & Coeficiente de Permeabilidade & $8,10 \mathrm{E}-01$ & - & IRIS (2004) \\
\hline LTd & & $2,20 \mathrm{E}+00$ & (cm/ano) & IRIS (2004) \\
\hline CETd & & $1,00 \mathrm{E}+01$ & (cm/ano) & IRIS (2004) \\
\hline $\mathrm{CPd}$ & & $4,60 \mathrm{E}+01$ & (cm/ano) & IRIS (2004) \\
\hline \multicolumn{5}{|c|}{ ParâmetrosDependentes dos COC e do solo } \\
\hline UF & Fração não lonizável do Composto Químico em Agua & $1,00 \mathrm{E}+00$ & & \\
\hline Heff & Coeficiente Efetivo da Lei de Henry & $4,62 \mathrm{E}-03$ & \multicolumn{2}{|c|}{ (L-agua/L-ar) } \\
\hline Csat,vap & Concentração de Saturação de Vapor & $6,99 \mathrm{E}-01$ & \multicolumn{2}{|c|}{ (mg/m3-ar) } \\
\hline Ksw & Coeficiente de Partição Fase Retida - Água Intersticial & $8,13 \mathrm{E}-05$ & \multicolumn{2}{|c|}{ (L-agua/kg-solo) } \\
\hline Csat,sol & Concentração de Saturação do Solo & $1,22 \mathrm{E}-07$ & \multicolumn{2}{|c|}{ (mg/kg-solo) } \\
\hline Deff,sol & Coeficiente de Difusão no Solo & $1,95 \mathrm{E}-03$ & \multirow{2}{*}{\multicolumn{2}{|c|}{$\frac{(\mathrm{cm} 2 / \mathrm{seg})}{(\mathrm{cm} 2 / \mathrm{seg})}$}} \\
\hline Deff,cap & Coeficiente de Difusão na Franja Capilar & $3,78 \mathrm{E}-04$ & & \\
\hline Deff,ws & Coeficiente de Difusão no Solo acima do Nível D'água & $1,86 \mathrm{E}-03$ & \multicolumn{2}{|c|}{$\frac{(\mathrm{cm} 2 / \mathrm{seg})}{(\mathrm{cm} 2 / \mathrm{seg})}$} \\
\hline Deff,crk & Coeficiente de Difusão nas Fundações dos Prédios & $4,91 \mathrm{E}-03$ & \multicolumn{2}{|c|}{ (cm2/seg) } \\
\hline $\mathrm{Rc}$ & Fator de Retardação da Fase Dissolvida & $2,71 \mathrm{E}+04$ & \multicolumn{2}{|c|}{$(\mathrm{cm} / \mathrm{s}) /(\mathrm{cm} / \mathrm{s})$} \\
\hline Ri & Fator de Retardação da Fase Vapor & $4,61 \mathrm{E}-04$ & \multicolumn{2}{|c|}{$(\mathrm{cm} / \mathrm{s}) /(\mathrm{cm} / \mathrm{s})$} \\
\hline \multicolumn{5}{|c|}{ Fatores de Volatilização entre Meios } \\
\hline & & RESIDENCIAL & COMERCIAL & \\
\hline VFs,esp & Fator de Volatilização do Solo Subsuperficial para Ambientes Fechados & $3,51 \mathrm{E}-08$ & $1,42 \mathrm{E}-08$ & (kg-solo/m3-ar) \\
\hline VFw,esp & Fator de Volatilização de Agua Subterrânea para Ambientes Fechados & $3,19 \mathrm{E}-04$ & $1,30 \mathrm{E}-04$ & (L-água/m3-ar) \\
\hline VFss,amb,1 & Fator de Volatilização do Solo Superficial para Ambientes Abertos & 8,85E-08 & 8,85E-08 & (kg-solo/m3-ar) \\
\hline VFss,amb,2 & Fator de Volatilização do Solo Superficial para Ambientes Abertos & $8,38 \mathrm{E}-06$ & $8,38 \mathrm{E}-06$ & (kg-solo/m3-ar) \\
\hline VFss,amb & Fator de Volatilização do Solo Superficial para Ambientes Abertos & $8,85 \mathrm{E}-08$ & $8,85 \mathrm{E}-08$ & (kg-solo/m3-ar) \\
\hline LFsw & Fator de Lixiviação do Solo Subsuperficial para Água & 4,59E-05 & 4,59E-05 & (kg-solo/L-ar) \\
\hline VFs,amb & Fator de Volatilização do Solo Subsuperficial para Ambientes Abertos & $4,89 \mathrm{E}-10$ & $4,89 \mathrm{E}-10$ & (kg-solo/m3-ar) \\
\hline VFw,amb & Fator de Volatilização de Água Subterrânea para Ambientes Abertos & $2,18 \mathrm{E}-06$ & $2,18 \mathrm{E}-06$ & (L-água/m3-ar) \\
\hline VFp & Fator de Emissão de Partículas & $6,90 \mathrm{E}-12$ & $6,90 \mathrm{E}-12$ & (kg-solo/m3-ar) \\
\hline
\end{tabular}




\begin{tabular}{|l|c|}
\hline NOME: & BENZO(g,h,i)PERILENO \\
\hline CAS RN: & $191-24-2$ \\
\hline FÓRMULA: & C22H12 \\
\hline
\end{tabular}

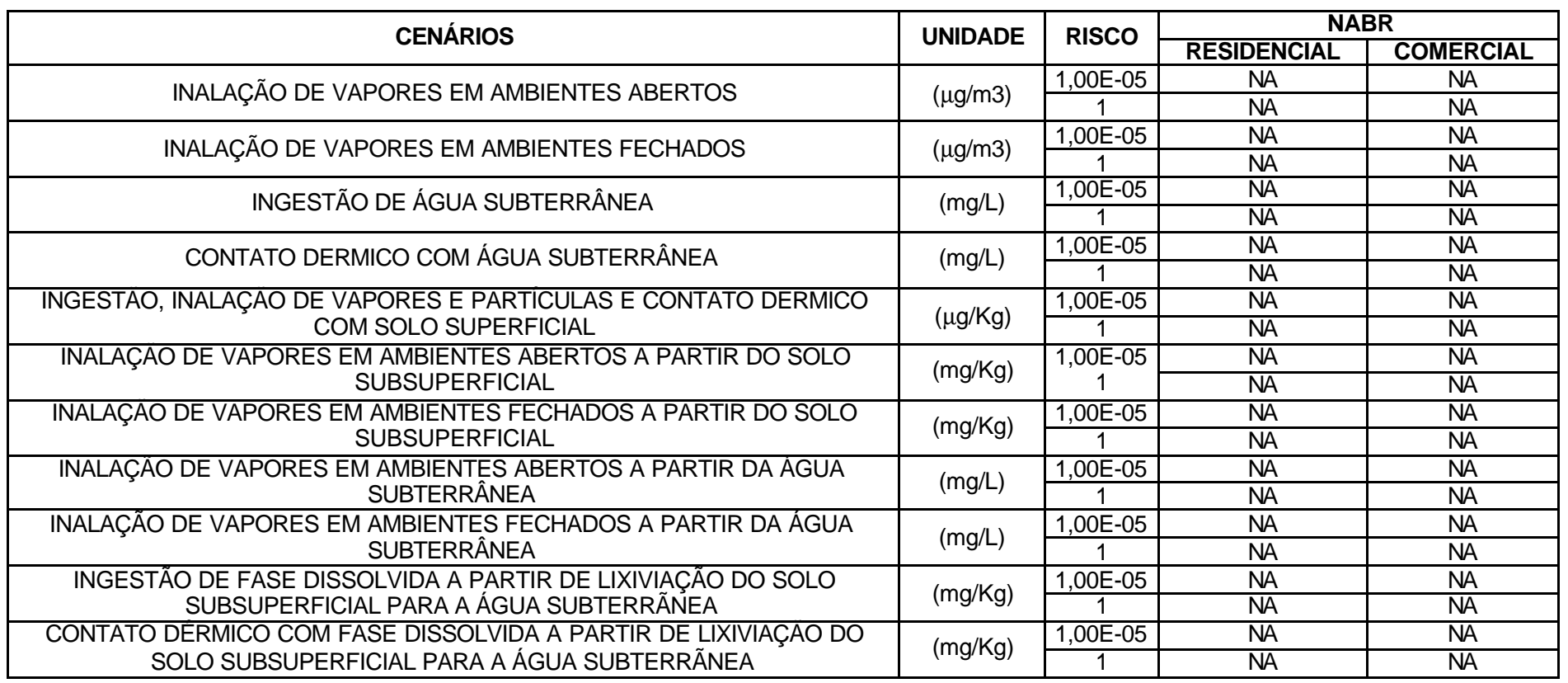

\begin{tabular}{|c|c|c|c|c|}
\hline \multicolumn{5}{|c|}{ Propriedades Físico-Químicas } \\
\hline PM & Peso Molecular & 276 & $(\mathrm{~g} / \mathrm{mol})$ & USEPA (1994) \\
\hline $\mathrm{S}$ & Solubilidade do Composto Puro em Agua & $2,60 \mathrm{E}-04$ & $(\mathrm{mg} / \mathrm{L})$ & USEPA (1996) \\
\hline $\mathrm{PV}$ & Pressão de Vapor & $1,41 \mathrm{E}-14$ & $(\mathrm{~mm} \mathrm{Hg})$ & USEPA (1994) \\
\hline $\mathrm{H}$ & Constante da Lei de Henry & $1,60 \mathrm{E}-06$ & $(\mathrm{~atm}-\mathrm{m} 3 / \mathrm{mol})$ & USEPA (1996) \\
\hline Dar & Coeficiente de Difusão no $\mathrm{Ar}$ & $4,90 \mathrm{E}-02$ & $(\mathrm{~cm} 2 / \mathrm{seg})$ & USEPA (1996) \\
\hline Dag & Coeficiente de Difusão na Água & $5,56 \mathrm{E}-06$ & $(\mathrm{~cm} 2 / \mathrm{seg})$ & USEPA (1996) \\
\hline $\log (\mathrm{Koc})$ & Logarítimo do Coeficiente de Partição carbono Organico - Água & $6,89 \mathrm{E}+00$ & $\log (\mathrm{L}-\mathrm{agua} / \mathrm{kg}-\mathrm{oc})$ & USEPA (1996) \\
\hline $\mathrm{Kd}$ & Coeficiente de Partição Solo - Água & $7,76 \mathrm{E}+04$ & - & USEPA (1996) \\
\hline $\log ($ Kow $)$ & Coeficiente de partição Octanol - Água & $6,58 \mathrm{E}+00$ & $(\mathrm{mg} / \mathrm{L})$ & USEPA (1996) \\
\hline \multicolumn{5}{|c|}{ ParâmetrosToxicológicos } \\
\hline SFo & Fator de Carcinogênicidade Oral & & $(1 /(\mathrm{mg} / \mathrm{kg}$-dia $))$ & IRIS (2004) \\
\hline SFd & Fator de Carcinogênicidade Dermal & & $(1 /(\mathrm{mg} / \mathrm{kg}-\mathrm{dia}))$ & IRIS (2004) \\
\hline $\mathrm{SFi}$ & Fator de Carcinogênicidade por Inalação & & $(1 /(\mathrm{mg} / \mathrm{kg}-\mathrm{dia}))$ & IRIS (2004) \\
\hline URFi & Unidade de Risco & & $(1 /(\mu \mathrm{g} / \mathrm{m} 3))$ & IRIS (2004) \\
\hline RfDo & Dose de Referência Oral & & (mg/kg-dia) & IRIS (2004) \\
\hline $\mathrm{RfDd}$ & Dose de Referência Dermal & & (mg/kg-dia) & IRIS (2004) \\
\hline RfDi & Concentração de Referência para Inalação & & (mg/m3-dia) & IRIS (2004) \\
\hline RAFo & Fator de Absorção Oral Relativa & $1,00 \mathrm{E}+00$ & - & IRIS (2004) \\
\hline RAFd & Fator de Absorção Dermal Relativa & $1,00 \mathrm{E}-01$ & - & IRIS (2004) \\
\hline PCd & Coeficiente de Permeabilidade & $1,20 \mathrm{E}+00$ & - & IRIS (2004) \\
\hline LTd & & $2,90 \mathrm{E}+00$ & (cm/ano) & IRIS (2004) \\
\hline CETd & & $1,40 \mathrm{E}+01$ & (cm/ano) & IRIS (2004) \\
\hline CPd & & $1,30 \mathrm{E}+02$ & (cm/ano) & IRIS (2004) \\
\hline \multicolumn{5}{|c|}{ ParâmetrosDependentes dos COC e do solo } \\
\hline UF & Fração não lonizável do Composto Químico em Agua & $1,00 \mathrm{E}+00$ & & \\
\hline Heff & Coeficiente Efetivo da Lei de Henry & $6,65 \mathrm{E}-05$ & \multicolumn{2}{|c|}{ (L-agua/L-ar) } \\
\hline Csat,vap & Concentração de Saturação de Vapor & $2,13 \mathrm{E}-10$ & \multirow{2}{*}{\multicolumn{2}{|c|}{$\frac{(\mathrm{mg} / \mathrm{m3}-\mathrm{ar})}{(\mathrm{L}-\mathrm{agua} / \mathrm{kg}-\mathrm{solo})}$}} \\
\hline Ksw & Coeficiente de Partição Fase Retida - Água Intersticial & $1,29 \mathrm{E}-05$ & & \\
\hline Csat,sol & Concentração de Saturação do Solo & 3,35E-09 & \\
\hline Deff,sol & Coeficiente de Difusão no Solo & 5,77E-03 & \multicolumn{2}{|c|}{$\begin{array}{c}\text { (mg/kg-solo) } \\
(\mathrm{cm} 2 / \mathrm{seg})\end{array}$} \\
\hline Deff,cap & Coeficiente de Difusão na Franja Capilar & $2,59 \mathrm{E}-02$ & \multicolumn{2}{|c|}{$(\mathrm{cm} 2 / \mathrm{seq})$} \\
\hline Deff,ws & Coeficiente de Difusão no Solo acima do Nível D'água & $5,83 \mathrm{E}-03$ & \multicolumn{2}{|c|}{$(\mathrm{cm} 2 / \mathrm{seg})$} \\
\hline Deff,crk & Coeficiente de Difusão nas Fundacões dos Prédios & $1,11 \mathrm{E}-02$ & \multicolumn{2}{|c|}{$(\mathrm{cm} 2 / \mathrm{seg})$} \\
\hline $\mathrm{Rc}$ & Fator de Retardação da Fase Dissolvida & $1,71 \mathrm{E}+05$ & \multicolumn{2}{|c|}{$(\mathrm{cm} / \mathrm{s}) /(\mathrm{cm} / \mathrm{s})$} \\
\hline$\overline{\mathrm{Ri}}$ & Fator de Retardação da Fase Vapor & $7,30 \mathrm{E}-05$ & \multicolumn{2}{|c|}{$(\mathrm{cm} / \mathrm{s}) /(\mathrm{cm} / \mathrm{s})$} \\
\hline \multicolumn{5}{|c|}{ Fatores de Volatilização entre Meios } \\
\hline & & RESIDENCIAL & COMERCIAL & \\
\hline VFs,esp & Fator de Volatilização do Solo Subsuperficial para Ambientes Fechados & $1,90 \mathrm{E}-10$ & $7,72 \mathrm{E}-11$ & (kg-solo/m3-ar) \\
\hline VFw,esp & Fator de Volatilização de Água Subterrânea para Ambientes Fechados & 1,17E-05 & 4,77E-06 & (L-água/m3-ar) \\
\hline VFss,amb,1 & Fator de Volatilização do Solo Superficial para Ambientes Abertos & 7,27E-09 & 7,27E-09 & (kg-solo/m3-ar) \\
\hline VFss,amb,2 & Fator de Volatilização do Solo Superficial para Ambientes Abertos & $8,38 \mathrm{E}-06$ & $8,38 \mathrm{E}-06$ & (kg-solo/m3-ar) \\
\hline VFss,amb & Fator de Volatilização do Solo Superficial para Ambientes Abertos & 7,27E-09 & 7,27E-09 & (kg-solo/m3-ar) \\
\hline LFsw & Fator de Lixiviação do Solo Subsuperficial para Agua & $7,28 \mathrm{E}-06$ & $7,28 \mathrm{E}-06$ & (kg-solo/L-ar) \\
\hline VFs,amb & Fator de Volatilização do Solo Subsuperficial para Ambientes Abertos & $3,30 \mathrm{E}-12$ & $3,30 \mathrm{E}-12$ & (kg-solo/m3-ar) \\
\hline VFw,amb & Fator de Volatilização de Água Subterrânea para Ambientes Abertos & $9,89 \mathrm{E}-08$ & $9,89 \mathrm{E}-08$ & (L-água/m3-ar) \\
\hline VFp & Fator de Emissão de Partículas & $6,90 \mathrm{E}-12$ & $6,90 \mathrm{E}-12$ & (kg-solo/m3-ar) \\
\hline
\end{tabular}




\begin{tabular}{|l|c|l|}
\hline NOME: & \multicolumn{2}{|c|}{ BENZO(k)FLUORANTENO } \\
\hline CAS RN: & $207-08-9$ & \\
\hline FÓRMULA: & C20H12 & \\
\hline
\end{tabular}

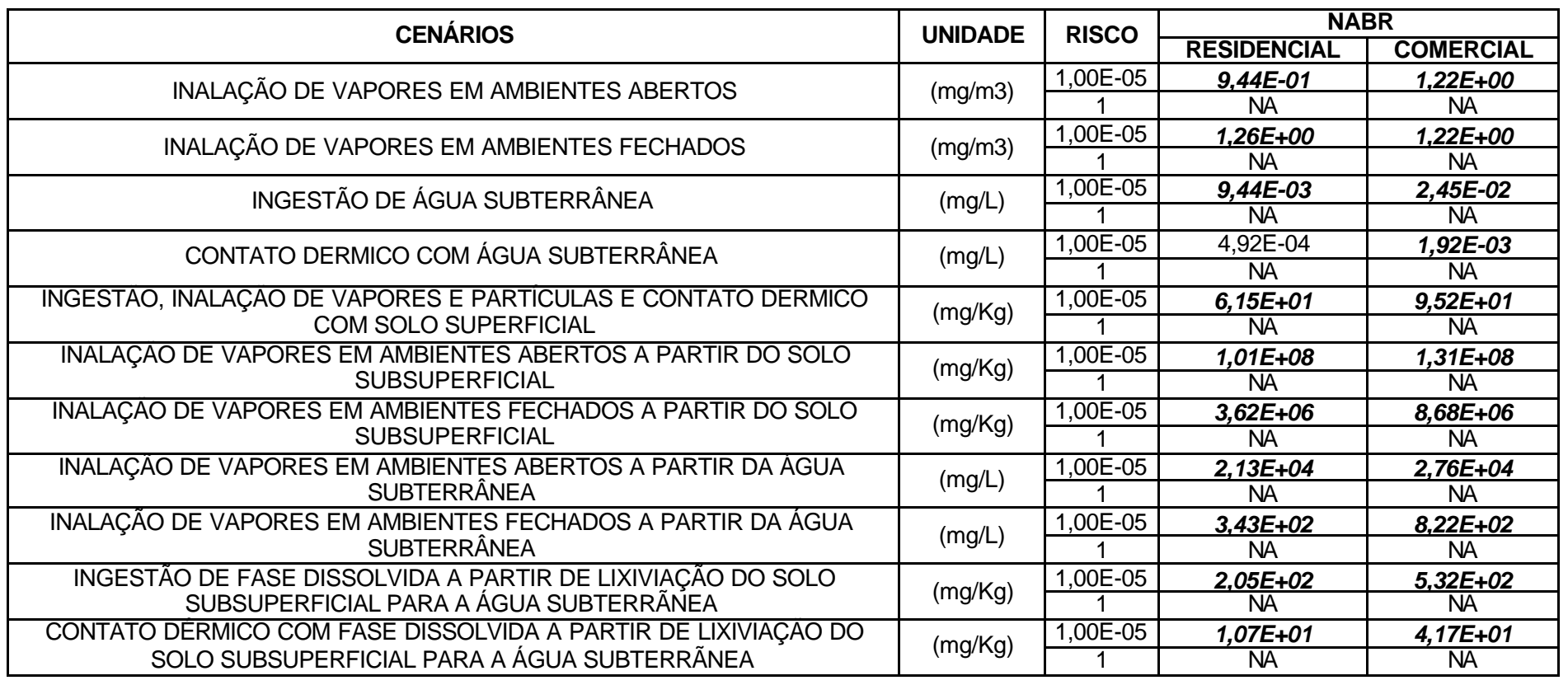

\begin{tabular}{|c|c|c|c|c|}
\hline \multicolumn{5}{|c|}{ Propriedades Físico-Químicas } \\
\hline PM & Peso Molecular & 252,32 & $(\mathrm{~g} / \mathrm{mol})$ & USEPA (1994) \\
\hline $\bar{S}$ & Solubilidade do Composto Puro em Agua & $8,00 \mathrm{E}-04$ & (mg/L) & Mackay(1992b) \\
\hline $\mathrm{PV}$ & Pressão de Vapor & $9,59 \mathrm{E}-11$ & $(\mathrm{~mm} \mathrm{Hg})$ & USEPA (1994) \\
\hline $\mathrm{H}$ & Constante da Lei de Henry & $8,29 \mathrm{E}-07$ & $(\mathrm{~atm}-\mathrm{m} 3 / \mathrm{mol})$ & USEPA (1996) \\
\hline Dar & Coeficiente de Difusão no $\mathrm{Ar}$ & $2,26 \mathrm{E}-02$ & $(\mathrm{~cm} 2 / \mathrm{seg})$ & USEPA (1996) \\
\hline$\overline{D a g}$ & Coeficiente de Difusão na Água & $5,56 \mathrm{E}-06$ & $(\mathrm{~cm} 2 / \mathrm{seg})$ & USEPA (1996) \\
\hline $\log (\mathrm{Koc})$ & Logarítimo do Coeficiente de Partição carbono Organico - Água & $6,09 \mathrm{E}+00$ & $\log (\mathrm{L}-\mathrm{agua} / \mathrm{kg}-\mathrm{oc})$ & WSPA(1993) \\
\hline $\mathrm{Kd}$ & Coeficiente de Partição Solo - Água & $1,23 \mathrm{E}+04$ & - & USEPA (1996) \\
\hline $\log ($ Kow $)$ & Coeficiente de partição Octanol - Água & $6,20 \mathrm{E}+00$ & (mg/L) & USEPA (1996) \\
\hline \multicolumn{5}{|c|}{ ParâmetrosToxicológicos } \\
\hline SFo & Fator de Carcinogênicidade Oral & 7,30E-02 & $(1 /(\mathrm{mg} / \mathrm{kg}-\mathrm{dia}))$ & IRIS (2004) \\
\hline SFd & Fator de Carcinogênicidade Dermal & $2,35 \mathrm{E}-01$ & $(1 /(\mathrm{mg} / \mathrm{kg}-\mathrm{dia}))$ & IRIS (2004) \\
\hline $\mathrm{SFi}$ & Fator de Carcinogênicidade por Inalação & $7,30 \mathrm{E}-02$ & $(1 /(\mathrm{mg} / \mathrm{kg}-\mathrm{dia}))$ & IRIS (2004) \\
\hline URFi & Unidade de Risco & $8,80 \mathrm{E}-06$ & $(1 /(\mathrm{mg} / \mathrm{m3}))$ & IRIS (2004) \\
\hline RfDo & Dose de Referência Oral & & (mg/kg-dia) & IRIS (2004) \\
\hline RfDd & Dose de Referência Dermal & & (mg/kg-dia) & IRIS (2004) \\
\hline RfDi & Concentração de Referência para Inalação & $1,00 \mathrm{E}-01$ & (mg/m3-dia) & IRIS (2004) \\
\hline RAFo & Fator de Absorção Oral Relativa & $1,00 \mathrm{E}+00$ & - & IRIS (2004) \\
\hline RAFd & Fator de Absorção Dermal Relativa & $1,30 \mathrm{E}-01$ & - & IRIS (2004) \\
\hline $\mathrm{PCd}$ & Coeficiente de Permeabilidade & $1,20 \mathrm{E}+00$ & - & IRIS (2004) \\
\hline LTd & & $3,00 \mathrm{E}+00$ & (cm/ano) & IRIS (2004) \\
\hline CETd & & $1,40 \mathrm{E}+01$ & (cm/ano) & IRIS (2004) \\
\hline $\mathrm{CPd}$ & & $1,30 \mathrm{E}+02$ & (cm/ano) & IRIS (2004) \\
\hline \multicolumn{5}{|c|}{ ParâmetrosDependentes dos COC e do solo } \\
\hline UF & Fração não lonizável do Composto Químico em Agua & $1,00 \mathrm{E}+00$ & \multirow{2}{*}{\multicolumn{2}{|c|}{ (L-agua/L-ar) }} \\
\hline Heff & Coeficiente Efetivo da Lei de Henry & $3,45 \mathrm{E}-05$ & & \\
\hline Csat,vap & Concentração de Saturação de Vapor & $1,32 \mathrm{E}-06$ & \multicolumn{2}{|c|}{ (mg/m3-ar) } \\
\hline Ksw & Coeficiente de Partição Fase Retida - Agua Intersticial & 8,13E-05 & \multicolumn{2}{|c|}{ (L-agua/kg-solo) } \\
\hline Csat,sol & Concentração de Saturação do Solo & $6,50 \mathrm{E}-08$ & \multicolumn{2}{|c|}{ (mg/kg-solo) } \\
\hline Deff,sol & Coeficiente de Difusão no Solo & $4,99 \mathrm{E}-03$ & \multicolumn{2}{|c|}{$(\mathrm{cm} 2 / \mathrm{seg})$} \\
\hline Deff,cap & Coeficiente de Difusão na Franja Capilar & $5,00 \mathrm{E}-02$ & \multicolumn{2}{|c|}{$\frac{(\mathrm{cm} 2 / \mathrm{seg})}{(\mathrm{cm} 2 / \mathrm{seg})}$} \\
\hline Deff,ws & Coeficiente de Difusão no Solo acima do Nível D'água & 5,05E-03 & \multirow{2}{*}{\multicolumn{2}{|c|}{$\frac{(\mathrm{cm} 2 / \mathrm{seg})}{(\mathrm{cm} 2 / \mathrm{seg})}$}} \\
\hline Deff,crk & Coeficiente de Difusão nas Fundações dos Prédios & 5,81E-03 & & \\
\hline Rc & Fator de Retardação da Fase Dissolvida & $2,71 \mathrm{E}+04$ & \multicolumn{2}{|c|}{$\frac{(\mathrm{cm} 2 / \mathrm{seg})}{(\mathrm{cm} / \mathrm{s}) /(\mathrm{cm} / \mathrm{s})}$} \\
\hline $\mathrm{Ri}$ & Fator de Retardação da Fase Vapor & $4,61 \mathrm{E}-04$ & \multicolumn{2}{|c|}{$\frac{(\mathrm{cm} / \mathrm{s}) /(\mathrm{cm} / \mathrm{s})}{(\mathrm{cm} / \mathrm{s}) /(\mathrm{cm} / \mathrm{s})}$} \\
\hline \multicolumn{5}{|c|}{ Fatores de Volatilização entre Meios } \\
\hline & & RESIDENCIAL & COMERCIAL & \\
\hline VFs,esp & Fator de Volatilização do Solo Subsuperficial para Ambientes Fechados & $3,47 \mathrm{E}-10$ & $1,41 \mathrm{E}-10$ & (kg-solo/m3-ar) \\
\hline VFw,esp & Fator de Volatilização de Água Subterrânea para Ambientes Fechados & 3,67E-06 & 1,49E-06 & (L-água/m3-ar) \\
\hline VFss,amb,1 & Fator de Volatilização do Solo Superficial para Ambientes Abertos & $1,22 \mathrm{E}-08$ & $1,22 \mathrm{E}-08$ & (kg-solo/m3-ar) \\
\hline VFss,amb,2 & Fator de Volatilização do Solo Superficial para Ambientes Abertos & $8,38 \mathrm{E}-06$ & 8,38E-06 & (kg-solo/m3-ar) \\
\hline VFss,amb & Fator de Volatilização do Solo Superficial para Ambientes Abertos & $1,22 \mathrm{E}-08$ & $1,22 \mathrm{E}-08$ & (kg-solo/m3-ar) \\
\hline LFsw & Fator de Lixiviação do Solo Subsuperficial para Agua & 4,59E-05 & 4,59E-05 & (kg-solo/L-ar) \\
\hline VFs,amb & Fator de Volatilização do Solo Subsuperficial para Ambientes Abertos & 9,33E-12 & 9,33E-12 & (kg-solo/m3-ar) \\
\hline VFw,amb & Fator de Volatilização de Agua Subterrânea para Ambientes Abertos & 4,44E-08 & 4,44E-08 & (L-água/m3-ar) \\
\hline VFp & Fator de Emissão de Partículas & $6,90 \mathrm{E}-12$ & $6,90 \mathrm{E}-12$ & (kg-solo/m3-ar) \\
\hline
\end{tabular}




\begin{tabular}{|l|c|}
\hline NOME: & CRISENO \\
\hline CAS RN: & $218-01-9$ \\
\hline FORMULA: & C18H12 \\
\hline
\end{tabular}

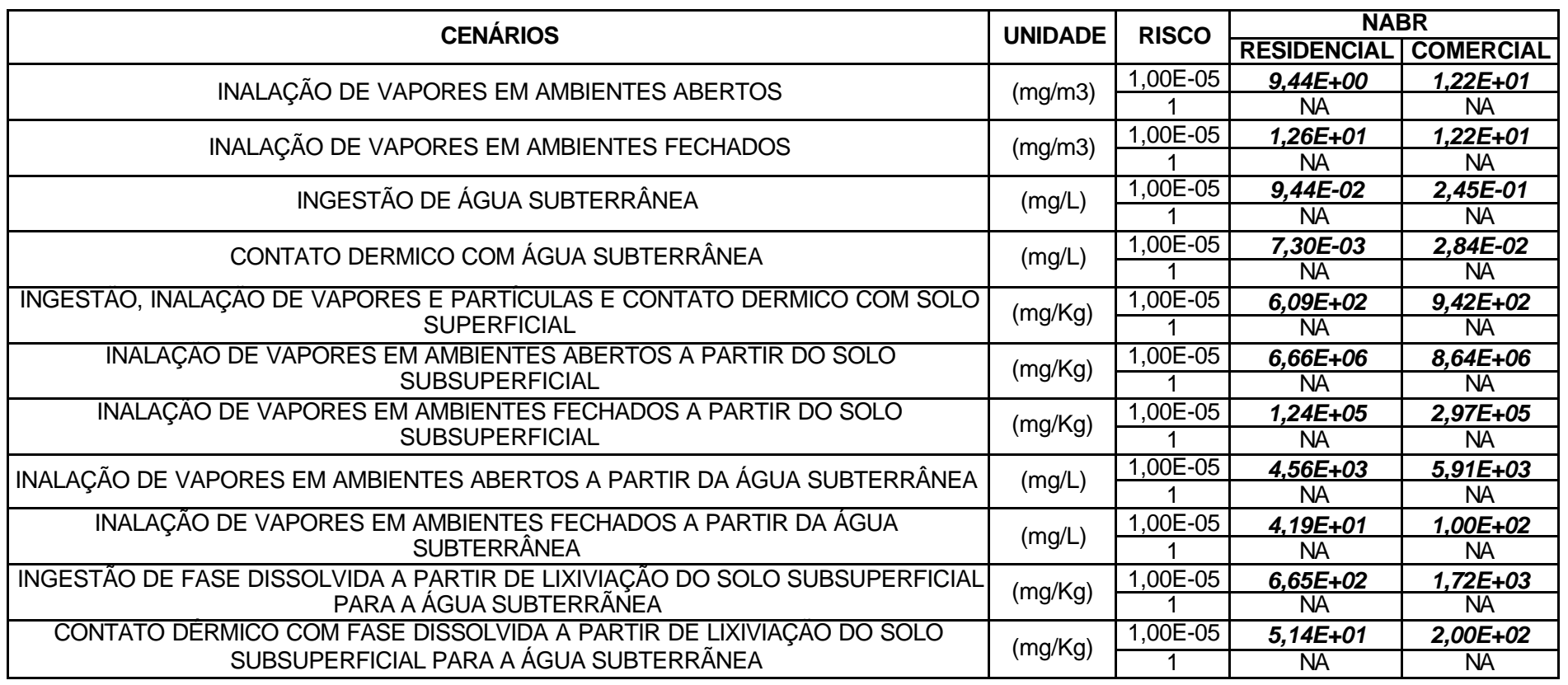

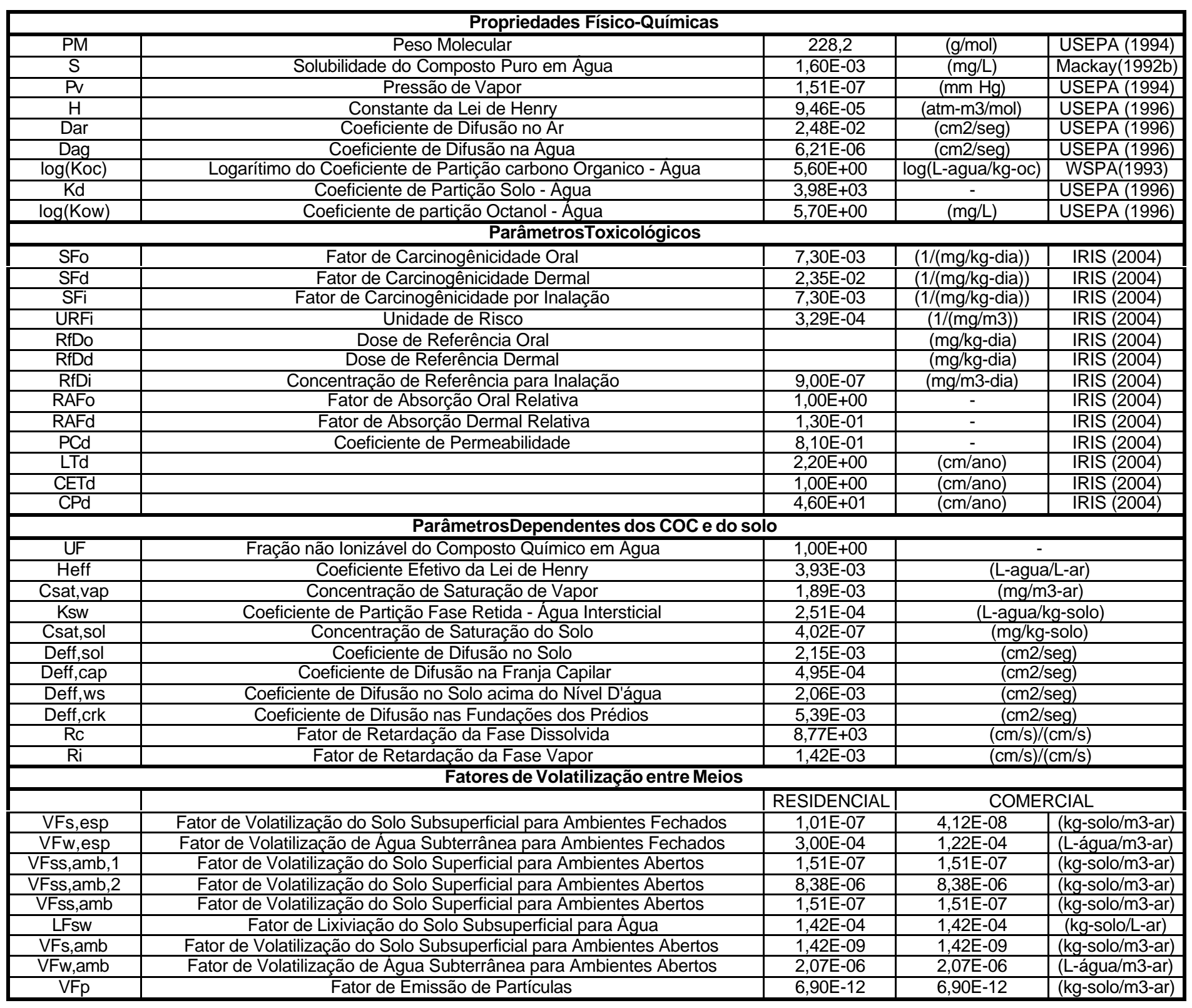




\begin{tabular}{|l|c|}
\hline NOME: & FENANTRENO \\
\hline CAS RN: & $85-01-8$ \\
\hline FÓRMULA: & C14H10 \\
\hline
\end{tabular}

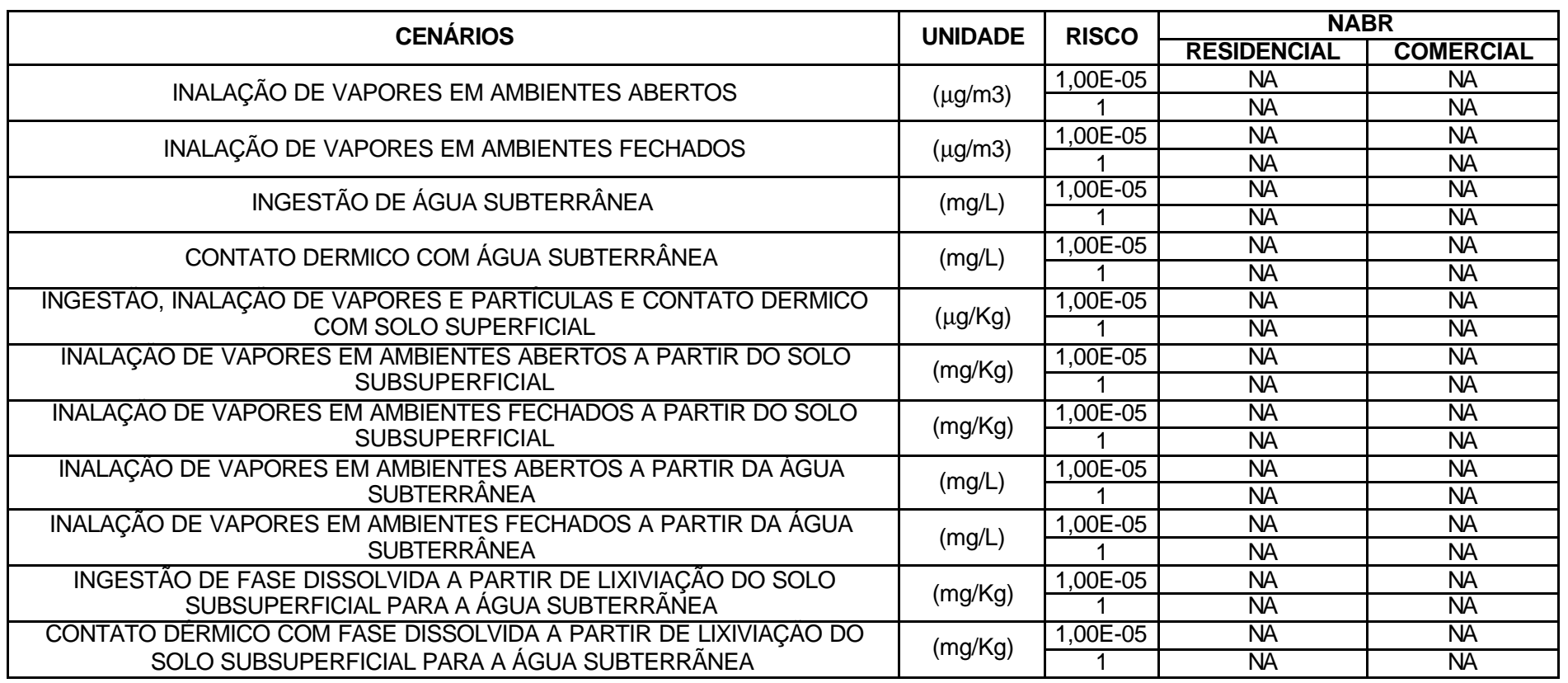

\begin{tabular}{|c|c|c|c|c|}
\hline \multicolumn{5}{|c|}{ Propriedades Físico-Químicas } \\
\hline PM & Peso Molecular & 178,22 & $(\mathrm{~g} / \mathrm{mol})$ & USEPA (1994) \\
\hline $\mathrm{S}$ & Solubilidade do Composto Puro em Agua & $4,81 \mathrm{E}+00$ & $(\mathrm{mg} / \mathrm{L})$ & Mackay(1992b) \\
\hline $\mathrm{PV}$ & Pressão de Vapor & $1,50 \mathrm{E}-04$ & $(\mathrm{~mm} \mathrm{Hg})$ & USEPA (1994) \\
\hline $\mathrm{H}$ & Constante da Lei de Henry & $3,20 \mathrm{E}-05$ & (atm-m3/mol) & USEPA (1996) \\
\hline Dar & Coeficiente de Difusão no Ar & $3,30 \mathrm{E}-02$ & $(\mathrm{~cm} 2 / \mathrm{seg})$ & USEPA (1996) \\
\hline Dag & Coeficiente de Difusão na Água & 7,47E-06 & $(\mathrm{cm} 2 / \mathrm{seg})$ & USEPA (1996) \\
\hline $\log (\mathrm{Koc})$ & Logarítimo do Coeficiente de Partição carbono Organico - Água & $4,16 \mathrm{E}+00$ & $\log (\mathrm{L}-\mathrm{agua} / \mathrm{kg}-\mathrm{oc})$ & WSPA(1993) \\
\hline $\mathrm{Kd}$ & Coeficiente de Partição Solo - Água & $1,45 \mathrm{E}+02$ & - & USEPA (1996) \\
\hline $\log ($ Kow $)$ & Coeficiente de partição Octanol - Agua & $4,57 \mathrm{E}+00$ & $(\mathrm{mg} / \mathrm{L})$ & USEPA (1996) \\
\hline \multicolumn{5}{|c|}{ ParâmetrosToxicológicos } \\
\hline SFo & Fator de Carcinogênicidade Oral & & (1/(mg/kg-dia)) & IRIS (2004) \\
\hline SFd & Fator de Carcinogênicidade Dermal & & $(1 /(\mathrm{mg} / \mathrm{kg}-\mathrm{dia}))$ & $\operatorname{IRIS}(2004)$ \\
\hline SFi & Fator de Carcinogênicidade por Inalação & & $(1 /(\mathrm{mg} / \mathrm{kg}$-dia $))$ & $\operatorname{IRIS}(2004)$ \\
\hline URFi & Unidade de Risco & & $(1 /(\mu \mathrm{g} / \mathrm{m} 3))$ & IRIS (2004) \\
\hline RfDo & Dose de Referência Oral & & (mg/kg-dia) & IRIS (2004) \\
\hline RfDd & Dose de Referência Dermal & & (mg/kg-dia) & IRIS (2004) \\
\hline RfDi & Concentração de Referência para Inalação & & (mg/kg-dia) & IRIS (2004) \\
\hline RAFo & Fator de Absorção Oral Relativa & $1,00 \mathrm{E}+00$ & - & IRIS (2004) \\
\hline RAFd & Fator de Absorção Dermal Relativa & $1,00 \mathrm{E}-01$ & - & IRIS (2004) \\
\hline PCd & Coeficiente de Permeabilidade & $2,30 \mathrm{E}-01$ & - & IRIS (2004) \\
\hline LTd & & $1,10 \mathrm{E}+00$ & (cm/ano) & IRIS (2004) \\
\hline CETd & & $5,60 \mathrm{E}+00$ & (cm/ano) & IRIS (2004) \\
\hline $\mathrm{CPd}$ & & $2,90 \mathrm{E}+00$ & (cm/ano) & IRIS (2004) \\
\hline \multicolumn{5}{|c|}{ ParâmetrosDependentes dos COC e do solo } \\
\hline UF & Fração não lonizável do Composto Químico em Agua & $1,00 \mathrm{E}+00$ & \multirow{2}{*}{\multicolumn{2}{|c|}{$\frac{-}{\text { (L-agua/L-ar) }}$}} \\
\hline Heff & Coeficiente Efetivo da Lei de Henry & 1,33E-03 & & \\
\hline Csat,vap & Concentração de Saturação de Vapor & $1,46 \mathrm{E}+00$ & \multicolumn{2}{|c|}{ (mg/m3-ar) } \\
\hline Ksw & Coeficiente de Partição Fase Retida - Água Intersticial & 6,91E-03 & \multicolumn{2}{|c|}{ (L-agua/kg-solo) } \\
\hline Csat,sol & Concentração de Saturação do Solo & 3,32E-02 & \multicolumn{2}{|c|}{ (mg/kg-solo) } \\
\hline Deff,sol & Coeficiente de Difusão no Solo & $2,93 \mathrm{E}-03$ & \multicolumn{2}{|c|}{$(\mathrm{cm} 2 / \mathrm{seg})$} \\
\hline Deff,cap & Coeficiente de Difusão na Franja Capilar & $1,75 \mathrm{E}-03$ & \multicolumn{2}{|c|}{$(\mathrm{cm} 2 / \mathrm{seg})$} \\
\hline Deff,ws & Coeficiente de Difusão no Solo acima do Nível D'água & $2,90 \mathrm{E}-03$ & \multicolumn{2}{|c|}{$(\mathrm{cm} 2 / \mathrm{seg})$} \\
\hline Deff,crk & Coeficiente de Difusão nas Fundações dos Prédios & 7,20E-03 & \multicolumn{2}{|c|}{$(\mathrm{cm} 2 / \mathrm{seg})$} \\
\hline $\mathrm{Rc}$ & Fator de Retardação da Fase Dissolvida & $3,20 \mathrm{E}+02$ & \multirow{2}{*}{\multicolumn{2}{|c|}{$\frac{(\mathrm{cm} / \mathrm{s}) /(\mathrm{cm} / \mathrm{s})}{(\mathrm{cm} / \mathrm{s}) /(\mathrm{cm} / \mathrm{s})}$}} \\
\hline $\mathrm{Ri}$ & Fator de Retardação da Fase Vapor & 3,92E-02 & & \\
\hline \multicolumn{5}{|c|}{ Fatores de Volatilização entre Meios } \\
\hline & & RESIDENCIAL & COMERCIAL & \\
\hline VFs,esp & Fator de Volatilização do Solo Subsuperficial para Ambientes Fechados & $1,26 \mathrm{E}-06$ & $5,13 \mathrm{E}-07$ & (kg-solo/m3-ar) \\
\hline VFw,esp & Fator de Volatilização de Agua Subterrânea para Ambientes Fechados & $1,38 \mathrm{E}-04$ & $5,61 \mathrm{E}-05$ & (L-água/m3-ar) \\
\hline VFss,amb,1 & Fator de Volatilização do Solo Superficial para Ambientes Abertos & 5,36E-07 & 5,36E-07 & (kg-solo/m3-ar) \\
\hline VFss,amb,2 & Fator de Volatilização do Solo Superficial para Ambientes Abertos & 8,38E-06 & $8,38 \mathrm{E}-06$ & (kg-solo/m3-ar) \\
\hline VFss,amb & Fator de Volatilização do Solo Superficial para Ambientes Abertos & 5,36E-07 & 5,36E-07 & (kg-solo/m3-ar) \\
\hline LFsw & Fator de Lixiviação do Solo Subsuperficial para Agua & 3,91E-03 & 3,91E-03 & (kg-solo/L-ar) \\
\hline VFs,amb & Fator de Volatilização do Solo Subsuperficial para Ambientes Abertos & 1,79E-08 & 1,79E-08 & (kg-solo/m3-ar) \\
\hline VFw,amb & Fator de Volatilização de Água Subterrânea para Ambientes Abertos & 9,85E-07 & 9,85E-07 & (L-água/m3-ar) \\
\hline VFp & Fator de Emissão de Partículas & $6,90 \mathrm{E}-12$ & $6,90 \mathrm{E}-12$ & (kg-solo/m3-ar) \\
\hline
\end{tabular}




\begin{tabular}{|l|c}
\hline NOME: & FLUORANTENO \\
\hline CAS RN: & $206-44-0$ \\
\hline FÓRMULA: & C16H10 \\
\hline
\end{tabular}

\begin{tabular}{|c|c|c|c|c|}
\hline \multirow{2}{*}{ CENÁRIOS } & \multirow{2}{*}{ UNIDADE } & \multirow{2}{*}{ RISCO } & \multicolumn{2}{|c|}{ NABR } \\
\hline & & & RESIDENCIAL & COMERCIAL \\
\hline \multirow{2}{*}{ INALAÇÃO DE VAPORES EM AMBIENTES ABERTOS } & \multirow[b]{2}{*}{$(\mu \mathrm{g} / \mathrm{m} 3)$} & $1,00 \mathrm{E}-05$ & $\mathrm{NA}$ & $\overline{N A}$ \\
\hline & & 1 & $4,96 E+02$ & $6,43 E+02$ \\
\hline \multirow{2}{*}{ INALAÇÃO DE VAPORES EM AMBIENTES FECHADOS } & \multirow{2}{*}{$(\mu \mathrm{g} / \mathrm{m} 3)$} & $1,00 \mathrm{E}-05$ & $\mathrm{NA}$ & NA \\
\hline & & 1 & $6,62 E+02$ & $6,43 E+02$ \\
\hline \multirow{2}{*}{ INGESTÃO DE ÁGUA SUBTERRÂNEA } & \multirow{2}{*}{$(\mathrm{mg} / \mathrm{L})$} & $1,00 \mathrm{E}-05$ & $\mathrm{NA}$ & $\mathrm{NA}$ \\
\hline & & 1 & $1,42 E+00$ & $3,68 E+00$ \\
\hline \multirow{2}{*}{ CONTATO DERMICO COM ÁGUA SUBTERRÂNEA } & \multirow[b]{2}{*}{ (mg/L) } & $1,00 \mathrm{E}-05$ & $\mathrm{NA}$ & $\mathrm{NA}$ \\
\hline & & 1 & $2,46 E-01$ & $9,57 E-01$ \\
\hline \multirow{2}{*}{$\begin{array}{c}\text { INGESTÃO, INALAÇÃO DE VAPORES E PARTICULAS E CONTATO DERMICO } \\
\text { COM SOLO SUPERFICIAL }\end{array}$} & \multirow{2}{*}{$(\mu \mathrm{g} / \mathrm{Kg})$} & $1,00 \mathrm{E}-05$ & $\mathrm{NA}$ & $\mathrm{NA}$ \\
\hline & & 1 & $1,80 E+04$ & $2,78 E+04$ \\
\hline \multirow{2}{*}{$\begin{array}{c}\text { INALAÇĀO DE VAPORES EM AMBIENTES ABERTOS A PARTIR DO SOLO } \\
\text { SUBSUPERFICIAL }\end{array}$} & \multirow{2}{*}{ (mg/Kg) } & $1,00 \mathrm{E}-05$ & NA & NA \\
\hline & & 1 & $4,32 E+08$ & $5,59 E+08$ \\
\hline \multirow{2}{*}{$\begin{array}{c}\text { INALAÇÄO DE VAPORES EM AMBIENTES FECHADOS A PARTIR DO SOLO } \\
\text { SUBSUPERFICIAL }\end{array}$} & \multirow{2}{*}{ (mg/Kg) } & $1,00 \mathrm{E}-05$ & NA & $\mathrm{NA}$ \\
\hline & & 1 & $8,34 E+06$ & $2,00 E+07$ \\
\hline \multirow{2}{*}{$\begin{array}{l}\text { INALAÇAO DE VAPORES EM AMBIENTESS ABERTOS A PARTIR DA AGUA } \\
\text { SUBTERRÂNEA }\end{array}$} & \multirow{2}{*}{ (mg/L) } & 1,00E-05 & $\mathrm{NA}$ & NA \\
\hline & & 1 & $1,05 E+06$ & $1,36 E+06$ \\
\hline \multirow{2}{*}{$\begin{array}{l}\text { INALAÇAO DE VAPORES EM AMBIENTES FECHADOS A PARTIR DA AGUA } \\
\text { SUBTERRÂNEA }\end{array}$} & \multirow{2}{*}{ (mg/L) } & 1,00E-05 & $\mathrm{NA}$ & $\mathrm{NA}$ \\
\hline & & 1 & $1,02 E+04$ & $2,45 E+04$ \\
\hline $\begin{array}{c}\text { INGESTÄO DE FASE DISSOLVIDA A PARTIR DE LIXIVIAÇÄO DO SOLO } \\
\text { SUBSUPERFICIAL PARA A ÁGUA SUBTERRÃNEA }\end{array}$ & $(\mathrm{mg} / \mathrm{Kg})$ & $1,00 \mathrm{E}-05$ & NA & $\mathrm{NA}$ \\
\hline \multirow{2}{*}{$\begin{array}{c}\text { CONTATO DÉRMICO COM FASE DISSOLVIDA A PARTIR DE LIXIVIAÇÃO DO } \\
\text { SOLO SUBSUPERFICIAL PARA A ÁGUA SUBTERRÂNEA }\end{array}$} & \multirow[b]{2}{*}{$(\mathrm{mg} / \mathrm{Kg})$} & $\frac{1}{1,00 \mathrm{E}-05}$ & $\frac{2,69 E+03}{N A}$ & $\frac{6,97 E+03}{N A}$ \\
\hline & & 1 & $4,67 E+02$ & $1,82 E+03$ \\
\hline
\end{tabular}

\begin{tabular}{|c|c|c|c|c|}
\hline \multicolumn{5}{|c|}{ Propriedades Físico-Químicas } \\
\hline PM & Peso Molecular & 202 & $(\mathrm{~g} / \mathrm{mol})$ & USEPA (1994) \\
\hline $\mathrm{S}$ & Solubilidade do Composto Puro em Agua & $2,06 \mathrm{E}-01$ & (mg/L) & Mackay(1992b) \\
\hline PV & Pressão de Vapor & $1,24 \mathrm{E}-06$ & $(\mathrm{~mm} \mathrm{Hg})$ & USEPA (1994) \\
\hline $\mathrm{H}$ & Constante da Lei de Henry & $1,61 \mathrm{E}-05$ & (atm-m3/mol) & USEPA (1996) \\
\hline Dar & Coeficiente de Difusão no $\mathrm{Ar}$ & 3,02E-02 & (cm2/seg) & USEPA (1996) \\
\hline Dag & Coeficiente de Difusão na Agua & $6,35 E-06$ & $(\mathrm{~cm} 2 / \mathrm{seg})$ & USEPA (1996) \\
\hline $\log (\mathrm{Koc})$ & Logarítimo do Coeficiente de Partição carbono Organico - Agua & $5,03 \mathrm{E}+00$ & $\log ($ L-agua/kg-oc) & WSPA(1993) \\
\hline $\mathrm{Kd}$ & Coeficiente de Partição Solo - Agua & 1,07E+03 & - & USEPA (1996) \\
\hline $\log (\mathrm{Kow})$ & Coeficiente de partição Octanol - Agua & $5,12 \mathrm{E}+00$ & $(\mathrm{mg} / \mathrm{L})$ & USEPA (1996) \\
\hline \multicolumn{5}{|c|}{ ParâmetrosToxicológicos } \\
\hline SFo & Fator de Carcinogênicidade Oral & & $(1 /(\mathrm{mg} / \mathrm{kg}$-dia $))$ & IRIS (2004) \\
\hline SFd & Fator de Carcinogênicidade Dermal & & $(1 /(\mathrm{mg} / \mathrm{kg}-$ dia $))$ & IRIS (2004) \\
\hline SFi & Fator de Carcinogênicidade por Inalação & & $(1 /(\mathrm{mg} / \mathrm{kg}-\mathrm{dia}))$ & IRIS (2004) \\
\hline URFi & Unidade de Risco & & $(1 /(\mu \mathrm{g} / \mathrm{m} 3))$ & IRIS (2004) \\
\hline RfDo & Dose de Referência Oral & $4,00 \mathrm{E}-02$ & (mg/kg-dia) & IRIS (2004) \\
\hline RfDd & Dose de Referência Dermal & 1,24E-02 & (mg/kg-dia) & IRIS (2004) \\
\hline RfDi & Concentração de Referência para Inalação & $1,40 \mathrm{E}-01$ & (mg/kg-dia) & IRIS (2004) \\
\hline RAFo & Fator de Absorção Oral Relativa & $1,00 \mathrm{E}+00$ & - & IRIS (2004) \\
\hline RAFd & Fator de Absorção Dermal Relativa & $1,30 \mathrm{E}-01$ & - & IRIS (2004) \\
\hline $\mathrm{PCd}$ & Coeficiente de Permeabilidade & $3,60 \mathrm{E}-01$ & - & IRIS (2004) \\
\hline LTd & & $1,50 \mathrm{E}+00$ & (cm/ano) & IRIS (2004) \\
\hline CETd & & $7,30 \mathrm{E}+00$ & (cm/ano) & IRIS (2004) \\
\hline $\mathrm{CPd}$ & & $8,90 \mathrm{E}+00$ & (cm/ano) & IRIS (2004) \\
\hline \multicolumn{5}{|c|}{ ParâmetrosDependentes dos COC e do solo } \\
\hline UF & Fração não lonizável do Composto Químico em Água & $1,00 \mathrm{E}+00$ & \multirow{2}{*}{\multicolumn{2}{|c|}{ (L-agua/L-ar) }} \\
\hline Heff & Coeficiente Efetivo da Lei de Henry & $6,70 \mathrm{E}-04$ & & \\
\hline Csat,vap & Concentração de Saturação de Vapor & $1,37 \mathrm{E}-02$ & \multicolumn{2}{|c|}{ (mg/m3-ar) } \\
\hline Ksw & Coeficiente de Partição Fase Retida - Água Intersticial & 9,33E-04 & \multirow{2}{*}{\multicolumn{2}{|c|}{$\frac{\text { (L-agua/kg-solo) }}{(\mathrm{mg} / \mathrm{kg}-\mathrm{s} / \mathrm{O})}$}} \\
\hline Csat,sol & Concentração de Saturação do Solo & 1,92E-04 & & \\
\hline Deff,sol & Coeficiente de Difusão no Solo & $2,76 \mathrm{E}-03$ & \multicolumn{2}{|c|}{$\frac{(\mathrm{mg} / \mathrm{kg} \text {-solo) }}{(\mathrm{cm} 2 / \mathrm{seg})}$} \\
\hline Deff,cap & Coeficiente de Difusão na Franja Capilar & $2,95 \mathrm{E}-03$ & \multicolumn{2}{|c|}{$(\mathrm{cm} 2 / \mathrm{seg})$} \\
\hline Deff,ws & Coeficiente de Difusão no Solo acima do Nível D'água & $2,76 \mathrm{E}-03$ & \multicolumn{2}{|c|}{$(\mathrm{cm} 2 / \mathrm{seg})$} \\
\hline Deff,crk & Coeficiente de Difusão nas Fundações dos Prédios & $6,61 \mathrm{E}-03$ & \multicolumn{2}{|c|}{$(\mathrm{cm} 2 / \mathrm{seg})$} \\
\hline Rc & Fator de Retardação da Fase Dissolvida & $2,36 \mathrm{E}+03$ & \multicolumn{2}{|c|}{$\frac{(\mathrm{cm} / \mathrm{s}) /(\mathrm{cm} / \mathrm{s})}{(\mathrm{cm} / \mathrm{c})(\mathrm{cm} / \mathrm{c})}$} \\
\hline $\mathrm{Ri}$ & Fator de Retardação da Fase Vapor & $5,29 \mathrm{E}-03$ & \multicolumn{2}{|c|}{$(\mathrm{cm} / \mathrm{s}) /(\mathrm{cm} / \mathrm{s})$} \\
\hline \multicolumn{5}{|c|}{ Fatores de Volatilização entre Meios } \\
\hline & & RESIDENCIAL & COMERCIAL & \\
\hline VFs,esp & Fator de Volatilização do Solo Subsuperficial para Ambientes Fechados & 7,93E-08 & $3,22 \mathrm{E}-08$ & (kg-solo/m3-ar) \\
\hline VFw,esp & Fator de Volatilização de Água Subterrânea para Ambientes Fechados & $6,48 \mathrm{E}-05$ & $2,63 \mathrm{E}-05$ & (L-água/m3-ar) \\
\hline VFss,amb,1 & Fator de Volatilização do Solo Superficial para Ambientes Abertos & $1,36 \mathrm{E}-07$ & 1,36E-07 & (kg-solo/m3-ar) \\
\hline VFss,amb,2 & Fator de Volatilização do Solo Superficial para Ambientes Abertos & $8,38 \mathrm{E}-06$ & $8,38 \mathrm{E}-06$ & (kg-solo/m3-ar) \\
\hline VFss,amb & Fator de Volatilização do Solo Superficial para Ambientes Abertos & $1,36 \mathrm{E}-07$ & $1,36 \mathrm{E}-07$ & (kg-solo/m3-ar) \\
\hline LFsw & Fator de Lixiviação do Solo Subsuperficial para Água & 5,27E-04 & 5,27E-04 & (kg-solo/L-ar) \\
\hline VFs,amb & Fator de Volatilização do Solo Subsuperficial para Ambientes Abertos & $1,15 \mathrm{E}-09$ & 1,15E-09 & (kg-solo/m3-ar) \\
\hline VFw,amb & Fator de Volatilização de Água Subterrânea para Ambientes Abertos & $4,72 \mathrm{E}-07$ & $4,72 \mathrm{E}-07$ & (L-água/m3-ar) \\
\hline VFp & Fator de Emissão de Partículas & $6,90 \mathrm{E}-12$ & $6,90 \mathrm{E}-12$ & (kg-solo/m3-ar) \\
\hline
\end{tabular}




\begin{tabular}{|l|c|}
\hline NOME: & FLUORENO \\
\hline CAS RN: & $86-73-7$ \\
\hline FÓRMULA: & $\mathrm{C} 13 \mathrm{H} 10$ \\
\hline
\end{tabular}

\section{CENÁRIOS}

INALAÇÃO DE VAPORES EM AMBIENTES ABERTOS

INALAÇÃO DE VAPORES EM AMBIENTES FECHADOS

INGESTÃO DE ÁGUA SUBTERRÂNEA

CONTATO DERMICO COM ÁGUA SUBTERRÂNEA

INGESTAO, INALAÇAO DE VAPORES E PARTICULAS E CONTATO DERMICO

COM SOLO SUPERFICIAL

INALAÇÃO DE VAPORES EM AMBIENTES ABERTOS A PARTIR DO SOLO

SUBSUPERFICIAL

INALAÇAO DE VAPORES EM AMBIENTES FECHADOS A PARTIR DO SOLO

SUBSUPERFICIAL

INALAÇÃO DE VAPORES EM AMBIENTES ABERTOS A PARTIR DA ÁGUA

SUBTERRÂNEA

INALAÇAO DE VAPORES EM AMBIENTES FECHADOS A PARTIR DA AGUA

SUBTERRÂNEA

INGESTAO DE FASE DISSOLVIDA A PARTIR DE LIXIVIACAO DO SOLO

SUBSUPERFICIAL PARA A ÁGUA SUBTERRÃNEA

CONTATO DERMICO COM FASE DISSOLVIDA A PARTIR DE LIXIVIAÇAO DO

SOLO SUBSUPERFICIAL PARA A ÁGUA SUBTERRÃNEA

\begin{tabular}{|c|c|c|c|}
\hline \multirow{2}{*}{ UNIDADE } & \multirow{2}{*}{ RISCO } & \multicolumn{2}{|c|}{ NABR } \\
\hline & & RESIDENCIAL & COMERCIAL \\
\hline \multirow[t]{2}{*}{$(\mu \mathrm{g} / \mathrm{m} 3)$} & 1,00E-05 & $\mathrm{NA}$ & NA \\
\hline & 1 & $4,96 E+02$ & $6,43 E+02$ \\
\hline \multirow[t]{2}{*}{$(\mu \mathrm{g} / \mathrm{m} 3)$} & $1,00 \mathrm{E}-05$ & NA & NA \\
\hline & 1 & $6,62 E+02$ & $6,43 E+02$ \\
\hline \multirow{2}{*}{ (mg/L) } & $1,00 \mathrm{E}-05$ & $\mathrm{NA}$ & $\mathrm{NA}$ \\
\hline & 1 & $1,42 \mathrm{E}+00$ & $3,68 E+00$ \\
\hline \multirow{2}{*}{ (mg/L) } & 1,00E-05 & $\mathrm{NA}$ & $\mathrm{NA}$ \\
\hline & 1 & $1,03 \mathrm{E}+00$ & $4,01 E+00$ \\
\hline \multirow{2}{*}{$(\mu \mathrm{g} / \mathrm{Kg})$} & $1,00 \mathrm{E}-05$ & $\overline{N A}$ & $\mathrm{NA}$ \\
\hline & 1 & $3,07 E+04$ & $5,52 E+04$ \\
\hline \multirow{2}{*}{$(\mathrm{mg} / \mathrm{Kg})$} & 1,00E-05 & $\mathrm{NA}$ & $\mathrm{NA}$ \\
\hline & 1 & $1,23 E+07$ & $1,60 E+07$ \\
\hline \multirow{2}{*}{$(\mathrm{mg} / \mathrm{Kg})$} & $1,00 \mathrm{E}-05$ & $\mathrm{NA}$ & $\mathrm{NA}$ \\
\hline & 1 & $2,30 E+05$ & $5,51 E+05$ \\
\hline \multirow{2}{*}{ (mg/L) } & 1,00E-05 & $\mathrm{NA}$ & $\mathrm{NA}$ \\
\hline & 1 & $2,40 E+05$ & $3,11 E+05$ \\
\hline \multirow{2}{*}{ (mg/L) } & $1,00 \mathrm{E}-05$ & $\mathrm{NA}$ & NA \\
\hline & 1 & $2,23 E+03$ & $5,34 E+03$ \\
\hline \multirow{2}{*}{$(\mathrm{mg} / \mathrm{Kg})$} & $1,00 \mathrm{E}-05$ & $\overline{N A}$ & $\mathrm{NA}$ \\
\hline & 1 & $3,47 E+02$ & $8,99 E+02$ \\
\hline \multirow{2}{*}{$(\mathrm{mg} / \mathrm{Kg})$} & $1,00 \mathrm{E}-05$ & $\overline{N A}$ & $\mathrm{NA}$ \\
\hline & 1 & $2,52 E+02$ & $9,82 E+02$ \\
\hline
\end{tabular}

\begin{tabular}{|c|c|c|c|c|}
\hline \multicolumn{5}{|c|}{ Propriedades Físico-Químicas } \\
\hline PM & Peso Molecular & 166 & $(\mathrm{~g} / \mathrm{mol})$ & USEPA (1994) \\
\hline $\mathrm{S}$ & Solubilidade do Composto Puro em Agua & $1,98 \mathrm{E}+00$ & $(\mathrm{mg} / \mathrm{L})$ & Mackay(1992b) \\
\hline $\mathrm{PV}$ & Pressão de Vapor & $8,50 \mathrm{E}-03$ & $(\mathrm{~mm} \mathrm{Hg})$ & USEPA (1994) \\
\hline $\mathrm{H}$ & Constante da Lei de Henry & $6,36 \mathrm{E}-05$ & (atm-m3/mol) & USEPA (1996) \\
\hline Dar & Coeficiente de Difusão no Ar & $3,63 \mathrm{E}-02$ & (cm2/seg) & USEPA (1996) \\
\hline Dag & Coeficiente de Difusão na Água & $7,88 \mathrm{E}-06$ & $(\mathrm{~cm} 2 / \mathrm{seg})$ & USEPA (1996) \\
\hline $\log (\mathrm{Koc})$ & Logarítimo do Coeficiente de Partição carbono Organico - Água & $4,14 \mathrm{E}+00$ & $\log (\mathrm{L}-\mathrm{agua} / \mathrm{kg}-\mathrm{oc})$ & WSPA(1993) \\
\hline $\mathrm{Kd}$ & Coeficiente de Partição Solo - Água & $1,38 \mathrm{E}+02$ & - & USEPA (1996) \\
\hline $\log ($ Kow $)$ & Coeficiente de partição Octanol - Aggua & $4,21 \mathrm{E}+00$ & $(\mathrm{mg} / \mathrm{L})$ & USEPA (1996) \\
\hline \multicolumn{5}{|c|}{ ParâmetrosToxicológicos } \\
\hline SFo & Fator de Carcinogênicidade Oral & & $(1 /(\mathrm{mg} / \mathrm{kg}-\mathrm{dia}))$ & IRIS (2004) \\
\hline SFd & Fator de Carcinogênicidade Dermal & & $(1 /(\mathrm{mg} / \mathrm{kg}-\mathrm{dia}))$ & IRIS (2004) \\
\hline SFi & Fator de Carcinogênicidade por Inalação & & $(1 /(\mathrm{mg} / \mathrm{kg}-\mathrm{dia}))$ & IRIS (2004) \\
\hline URFi & Unidade de Risco & & $(1 /(\mu \mathrm{g} / \mathrm{m} 3))$ & IRIS (2004) \\
\hline RfDo & Dose de Referência Oral & $4,00 \mathrm{E}-02$ & (mg/kg-dia) & IRIS (2004) \\
\hline RfDd & Dose de Referência Dermal & $2,00 \mathrm{E}-02$ & (mg/kg-dia) & IRIS (2004) \\
\hline RfDi & Concentração de Referência para Inalação & $1,40 \mathrm{E}-01$ & (mg/kg-dia) & IRIS (2004) \\
\hline RAFo & Fator de Absorção Oral Relativa & $1,00 \mathrm{E}+00$ & - & IRIS (2004) \\
\hline RAFd & Fator de Absorção Dermal Relativa & $5,00 \mathrm{E}-02$ & - & IRIS (2004) \\
\hline $\mathrm{PCd}$ & Coeficiente de Permeabilidade & $3,60 \mathrm{E}-01$ & - & IRIS (2004) \\
\hline LTd & & & (cm/ano) & IRIS (2004) \\
\hline CETd & & & (cm/ano) & IRIS (2004) \\
\hline $\mathrm{CPd}$ & & & (cm/ano) & IRIS (2004) \\
\hline \multicolumn{5}{|c|}{ ParâmetrosDependentes dos COC e do solo } \\
\hline UF & Fração não lonizável do Composto Químico em Água & $1,00 \mathrm{E}+00$ & & \\
\hline Heff & Coeficiente Efetivo da Lei de Henry & $2,65 \mathrm{E}-03$ & \multicolumn{2}{|c|}{ (L-agua/L-ar) } \\
\hline Csat,vap & Concentração de Saturação de Vapor & $7,72 \mathrm{E}+01$ & \multicolumn{2}{|c|}{ (mg/m3-ar) } \\
\hline Ksw & Coeficiente de Partição Fase Retida - Agua Intersticial & $7,24 \mathrm{E}-03$ & \multirow{2}{*}{\multicolumn{2}{|c|}{ (L-agua/kg-solo) }} \\
\hline Csat,sol & Concentração de Saturação do Solo & $1,43 \mathrm{E}-02$ & & \\
\hline Deff,sol & Coeficiente de Difusão no Solo & $3,16 \mathrm{E}-03$ & \multicolumn{2}{|c|}{$(\mathrm{cm} 2 / \mathrm{seg})$} \\
\hline Deff,cap & Coeficiente de Difusão na Franja Capilar & $9,32 \mathrm{E}-04$ & \multicolumn{2}{|c|}{$(\mathrm{cm} 2 / \mathrm{seg})$} \\
\hline Deff,ws & Coeficiente de Difusão no Solo acima do Nível D'água & $3,07 \mathrm{E}-03$ & \multicolumn{2}{|c|}{ (cm2/seg) } \\
\hline Deff,crk & Coeficiente de Difusão nas Fundações dos Prédios & 7,90E-03 & \multicolumn{2}{|c|}{$\frac{(\mathrm{cm} 2 / \mathrm{seg})}{(\mathrm{cm} / \mathrm{s}) /(\mathrm{cm} / \mathrm{s})}$} \\
\hline Rc & Fator de Retardação da Fase Dissolvida & $3,05 \mathrm{E}+02$ & \multirow{2}{*}{\multicolumn{2}{|c|}{$\frac{(\mathrm{cm} / \mathrm{s}) /(\mathrm{cm} / \mathrm{s})}{(\mathrm{cm} / \mathrm{s}) /(\mathrm{cm} / \mathrm{s})}$}} \\
\hline $\mathrm{Ri}$ & Fator de Retardação da Fase Vapor & $4,10 \mathrm{E}-02$ & & \\
\hline \multicolumn{5}{|c|}{ Fatores de Volatilização entre Meios } \\
\hline & & RESIDENCIAL & COMERCIAL & \\
\hline VFs,esp & Fator de Volatilização do Solo Subsuperficial para Ambientes Fechados & $2,88 \mathrm{E}-06$ & $1,17 \mathrm{E}-06$ & (kg-solo/m3-ar) \\
\hline VFw,esp & Fator de Volatilização de Agua Subterrânea para Ambientes Fechados & $2,97 \mathrm{E}-04$ & $1,21 \mathrm{E}-04$ & (L-água/m3-ar) \\
\hline VFss,amb,1 & Fator de Volatilização do Solo Superficial para Ambientes Abertos & 8,03E-07 & 8,03E-07 & (kg-solo/m3-ar) \\
\hline VFss,amb,2 & Fator de Volatilização do Solo Superficial para Ambientes Abertos & $8,38 \mathrm{E}-06$ & $8,38 \mathrm{E}-06$ & (kg-solo/m3-ar) \\
\hline VFss,amb & Fator de Volatilização do Solo Superficial para Ambientes Abertos & $8,03 \mathrm{E}-07$ & $8,03 \mathrm{E}-07$ & (kg-solo/m3-ar) \\
\hline LFsw & Fator de Lixiviação do Solo Subsuperficial para Agua & 4,09E-03 & 4,09E-03 & (kg-solo/L-ar) \\
\hline VFs,amb & Fator de Volatilização do Solo Subsuperficial para Ambientes Abertos & 4,03E-08 & 4,03E-08 & (kg-solo/m3-ar) \\
\hline VFw,amb & Fator de Volatilização de Agua Subterrânea para Ambientes Abertos & $2,07 \mathrm{E}-06$ & $2,07 \mathrm{E}-06$ & (L-água/m3-ar) \\
\hline VFp & Fator de Emissão de Partículas & $6,90 \mathrm{E}-12$ & $6,90 \mathrm{E}-12$ & (kg-solo/m3-ar) \\
\hline
\end{tabular}




\begin{tabular}{|l|c|l|}
\hline NOME: & \multicolumn{2}{|c|}{ INDENO(1,2,3-cd)PIRENO } \\
\hline CAS RN: & $193-39-5$ & \\
\hline FÓRMULA: & C21H24 & \\
\hline
\end{tabular}

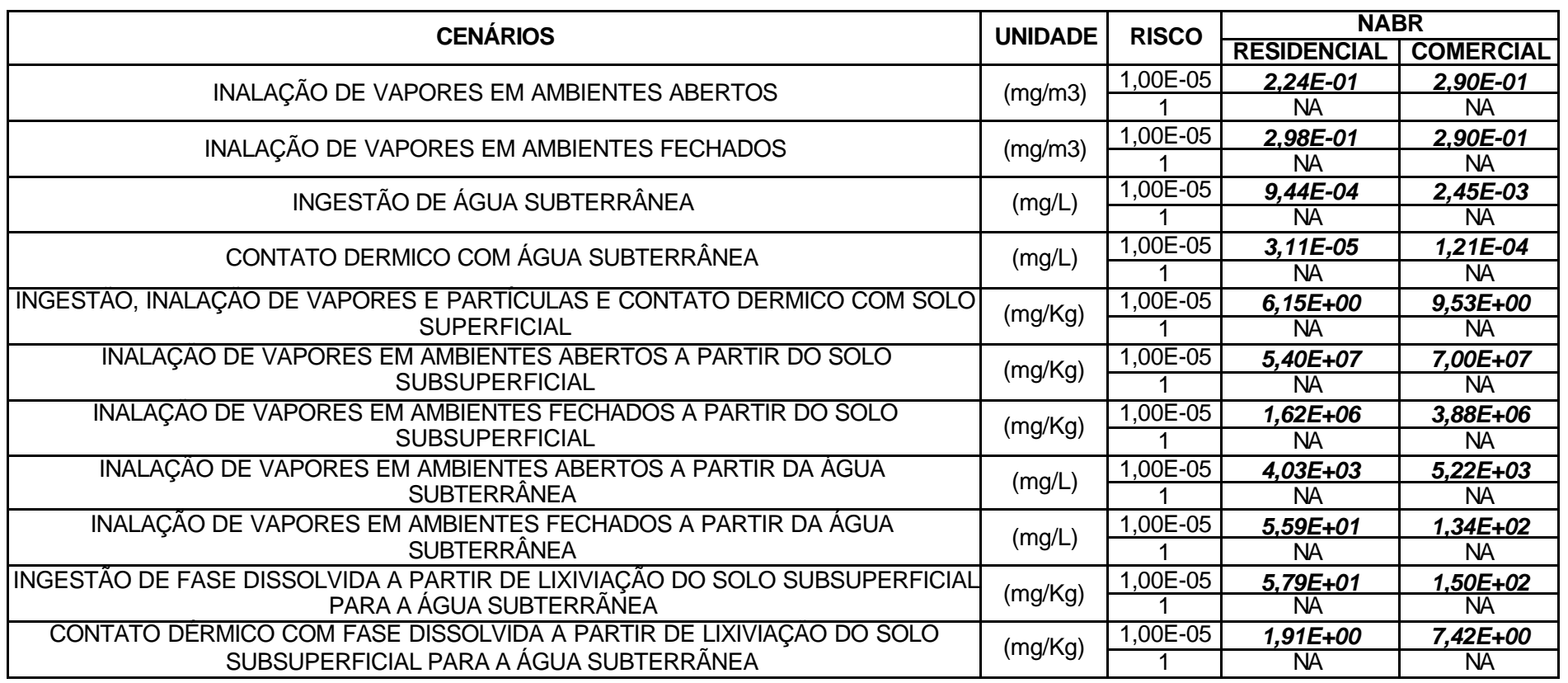

\begin{tabular}{|c|c|c|c|c|}
\hline \multicolumn{5}{|c|}{ Propriedades Físico-Químicas } \\
\hline PM & Peso Molecular & 278,35 & $(\mathrm{~g} / \mathrm{mol})$ & USEPA (1994) \\
\hline $\mathrm{S}$ & Solubilidade do Composto Puro em Agua & $2,49 \mathrm{E}-03$ & $(\mathrm{mg} / \mathrm{L})$ & Mackay(1992b) \\
\hline $\mathrm{PV}$ & Pressão de Vapor & $1,00 \mathrm{E}-10$ & $\overline{(\mathrm{mm} \mathrm{Hg})}$ & USEPA (1994) \\
\hline $\mathrm{H}$ & Constante da Lei de Henry & $6,11 \mathrm{E}-07$ & $(\mathrm{~atm}-\mathrm{m} 3 / \mathrm{mol})$ & USEPA (1996) \\
\hline Dar & Coeficiente de Difusão no $\mathrm{Ar}$ & $2,02 \mathrm{E}-02$ & $(\mathrm{~cm} 2 / \mathrm{seg})$ & USEPA (1996) \\
\hline$\overline{D a g}$ & Coeficiente de Difusão na Água & $5,18 \mathrm{E}-06$ & $(\mathrm{~cm} 2 / \mathrm{seg})$ & USEPA (1996) \\
\hline $\log (\mathrm{Koc})$ & Logarítimo do Coeficiente de Partição carbono Organico - Água & $6,58 \mathrm{E}+00$ & $\log ($ L-agua/kg-oc) & WSPA(1993) \\
\hline $\mathrm{Kd}$ & Coeficiente de Partição Solo - Água & $3,80 \mathrm{E}+04$ & - & USEPA (1996) \\
\hline $\log$ (Kow) & Coeficiente de partição Octanol - Água & $6,69 \mathrm{E}+00$ & $(\mathrm{mg} / \mathrm{L})$ & USEPA (1996) \\
\hline \multicolumn{5}{|c|}{ ParâmetrosToxicológicos } \\
\hline SFo & Fator de Carcinogênicidade Oral & $7,30 \mathrm{E}+00$ & $(1 /(\mathrm{mg} / \mathrm{kg}-$ dia $))$ & IRIS (2004) \\
\hline SFd & Fator de Carcinogênicidade Dermal & $2,35 \mathrm{E}+01$ & $(1 /(\mathrm{mg} / \mathrm{kg}-\mathrm{dia}))$ & IRIS (2004) \\
\hline SFi & Fator de Carcinogênicidade por Inalação & $7,30 \mathrm{E}+00$ & $(1 /(\mathrm{mg} / \mathrm{kg}$-dia $))$ & IRIS (2004) \\
\hline URFi & Unidade de Risco & & $(1 /(\mathrm{mg} / \mathrm{m3}))$ & IRIS (2004) \\
\hline RfDo & Dose de Referência Oral & & (mg/kg-dia) & IRIS (2004) \\
\hline RfDd & Dose de Referência Dermal & & (mg/kg-dia) & IRIS (2004) \\
\hline RfDi & Concentração de Referência para Inalação & $4,00 \mathrm{E}-01$ & (mg/m3-dia) & IRIS (2004) \\
\hline RAFo & Fator de Absorção Oral Relativa & $1,00 \mathrm{E}+00$ & - & IRIS (2004) \\
\hline RAFd & Fator de Absorção Dermal Relativa & $1,30 \mathrm{E}-01$ & - & IRIS (2004) \\
\hline $\mathrm{PCd}$ & Coeficiente de Permeabilidade & $2,70 \mathrm{E}+00$ & - & IRIS (2004) \\
\hline LTd & & $4,40 \mathrm{E}+00$ & (cm/ano) & IRIS (2004) \\
\hline CETd & & $2,10 \mathrm{E}+01$ & (cm/ano) & IRIS (2004) \\
\hline $\mathrm{CPd}$ & & $6,90 \mathrm{E}+02$ & (cm/ano) & IRIS (2004) \\
\hline \multicolumn{5}{|c|}{ ParâmetrosDependentes dos COC e do solo } \\
\hline UF & Fração não lonizável do Composto Químico em Agua & $1,00 \mathrm{E}+00$ & \multirow{2}{*}{\multicolumn{2}{|c|}{ (L-agua/L-ar) }} \\
\hline Heff & Coeficiente Efetivo da Lei de Henry & $2,54 \mathrm{E}-05$ & & \\
\hline Csat,vap & Concentração de Saturação de Vapor & $1,52 \mathrm{E}-06$ & \multicolumn{2}{|c|}{ (mg/m3-ar) } \\
\hline Ksw & Coeficiente de Partição Fase Retida - Agua Intersticial & $2,63 \mathrm{E}-05$ & \multicolumn{2}{|c|}{ (L-agua/kg-solo) } \\
\hline Csat,sol & Concentração de Saturação do Solo & $6,55 \mathrm{E}-08$ & \multicolumn{2}{|c|}{ (mg/kg-solo) } \\
\hline Deff,sol & Coeficiente de Difusão no Solo & $5,59 \mathrm{E}-03$ & \multicolumn{2}{|c|}{$(\mathrm{cm} 2 / \mathrm{seg})$} \\
\hline Deff,cap & Coeficiente de Difusão na Franja Capilar & 6,32E-02 & \multicolumn{2}{|c|}{$(\mathrm{cm} 2 / \mathrm{seg})$} \\
\hline Deff,ws & Coeficiente de Difusão no Solo acima do Nível D'água & $5,66 \mathrm{E}-03$ & \multirow{2}{*}{\multicolumn{2}{|c|}{$\begin{array}{l}(\mathrm{cm} 2 / \mathrm{seg}) \\
(\mathrm{cm} 2 / \mathrm{seq})\end{array}$}} \\
\hline Deff,crk & Coeficiente de Difusão nas Fundações dos Prédios & 5,53E-03 & & \\
\hline Rc & Fator de Retardação da Fase Dissolvida & $8,38 \mathrm{E}+04$ & \multicolumn{2}{|c|}{$\frac{(\mathrm{cm} 2 / \mathrm{seg})}{(\mathrm{cm} / \mathrm{s}) /(\mathrm{cm} / \mathrm{s})}$} \\
\hline $\mathrm{Ri}$ & Fator de Retardação da Fase Vapor & $1,49 \mathrm{E}-04$ & \multicolumn{2}{|c|}{$\frac{(\mathrm{cm} / \mathrm{s}) /(\mathrm{cm} / \mathrm{s})}{(\mathrm{cm} / \mathrm{s}) /(\mathrm{cm} / \mathrm{s})}$} \\
\hline \multicolumn{5}{|c|}{ Fatores de Volatilização entre Meios } \\
\hline & & RESIDENCIAL & COMERCIAL & \\
\hline VFs,esp & Fator de Volatilização do Solo Subsuperficial para Ambientes Fechados & $8,01 \mathrm{E}-11$ & $3,25 \mathrm{E}-11$ & (kg-solo/m3-ar) \\
\hline VFw,esp & Fator de Volatilização de Água Subterrânea para Ambientes Fechados & 2,67E-06 & 1,08E-06 & (L-água/m3-ar) \\
\hline VFss,amb, 1 & Fator de Volatilização do Solo Superficial para Ambientes Abertos & $6,32 \mathrm{E}-09$ & $6,32 \mathrm{E}-09$ & (kg-solo/m3-ar) \\
\hline VFss,amb,2 & Fator de Volatilização do Solo Superficial para Ambientes Abertos & $8,38 \mathrm{E}-06$ & $8,38 \mathrm{E}-06$ & (kg-solo/m3-ar) \\
\hline VFss,amb & Fator de Volatilização do Solo Superficial para Ambientes Abertos & $6,32 \mathrm{E}-09$ & 6,32E-09 & (kg-solo/m3-ar) \\
\hline LFsw & Fator de Lixiviação do Solo Subsuperficial para Agua & $1,49 \mathrm{E}-05$ & $1,49 \mathrm{E}-05$ & (kg-solo/L-ar) \\
\hline VFs,amb & Fator de Volatilização do Solo Subsuperficial para Ambientes Abertos & $2,49 \mathrm{E}-12$ & $2,49 \mathrm{E}-12$ & (kg-solo/m3-ar) \\
\hline VFw,amb & Fator de Volatilização de Agua Subterrânea para Ambientes Abertos & 3,67E-08 & 3,67E-08 & (L-água/m3-ar) \\
\hline VFp & Fator de Emissão de Partículas & $6,90 \mathrm{E}-12$ & 6,90E-12 & (kg-solo/m3-ar) \\
\hline
\end{tabular}




\begin{tabular}{|l|c|}
\hline NOME: & NAFTALENO \\
\hline CAS RN: & $91-20-3$ \\
\hline FORMULA: & C10H8 \\
\hline
\end{tabular}

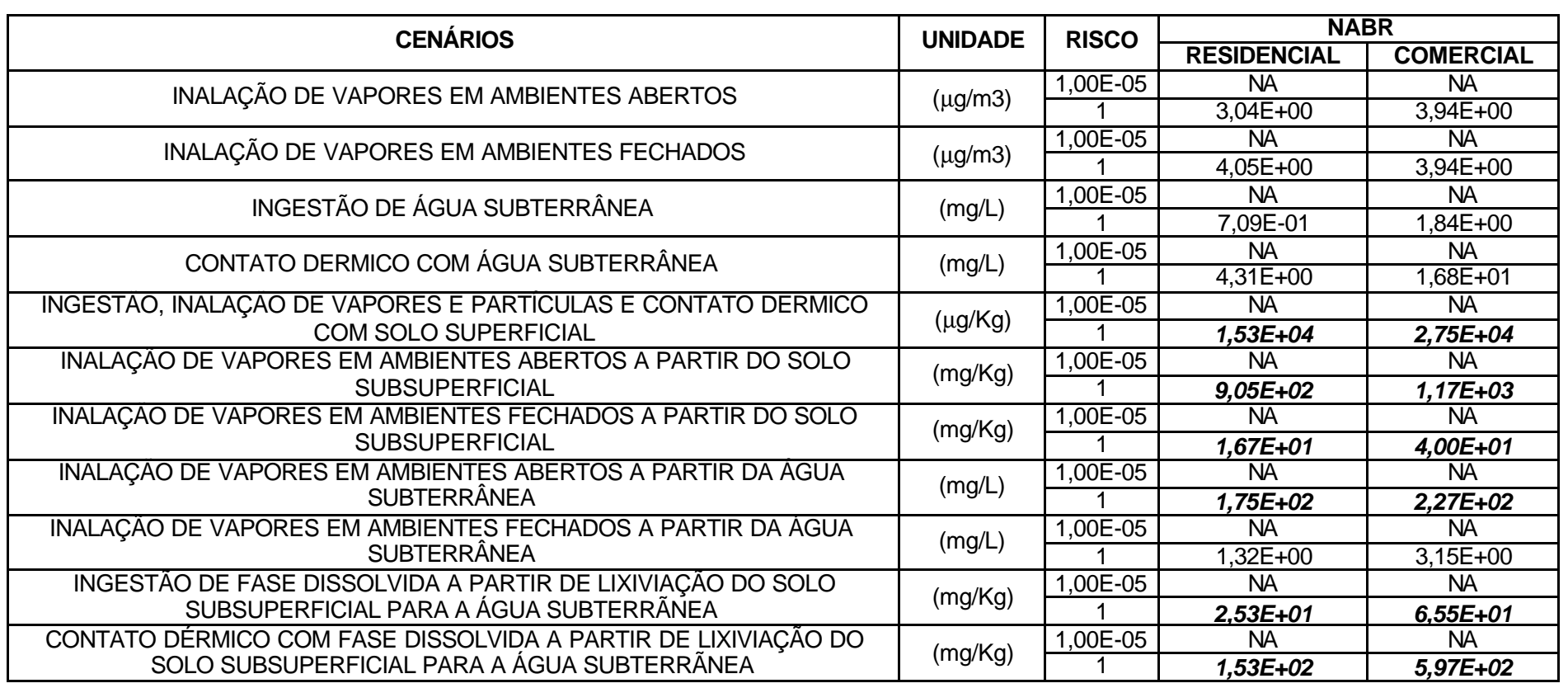

\begin{tabular}{|c|c|c|c|c|}
\hline \multicolumn{5}{|c|}{ Propriedades Físico-Químicas } \\
\hline PM & Peso Molecular & 128,2 & $(\mathrm{~g} / \mathrm{mol})$ & USEPA (1994) \\
\hline S & Solubilidade do Composto Puro em Água & $3,10 \mathrm{E}+01$ & $(\mathrm{mg} / \mathrm{L})$ & USEPA (1996) \\
\hline $\mathrm{PV}$ & Pressão de Vapor & $1,82 \mathrm{E}-01$ & $(\mathrm{~mm} \mathrm{Hg})$ & USEPA (1994) \\
\hline $\mathrm{H}$ & Constante da Lei de Henry & 4,83E-04 & $(\mathrm{atm}-\mathrm{m} 3 / \mathrm{mol})$ & USEPA (1996) \\
\hline Dar & Coeficiente de Difusão no Ar & $5,90 \mathrm{E}-02$ & $(\mathrm{~cm} 2 / \mathrm{seg})$ & USEPA (1996) \\
\hline Dag & Coeficiente de Difusão na Agua & $7,50 \mathrm{E}-06$ & $(\mathrm{~cm} 2 / \mathrm{seg})$ & USEPA (1996) \\
\hline $\log (\mathrm{Koc})$ & Logarítimo do Coeficiente de Partição carbono Organico - Água & $3,30 \mathrm{E}+00$ & $\log (\mathrm{L}-$ agua/kg-oc) & USEPA (1996) \\
\hline $\mathrm{Kd}$ & Coeficiente de Partição Solo - Agua & $2,00 \mathrm{E}+01$ & - & USEPA (1996) \\
\hline$\overline{l o g}($ Kow $)$ & Coeficiente de partição Octanol - Agua & $3,36 \mathrm{E}+00$ & $(\mathrm{mg} / \mathrm{L})$ & USEPA (1996) \\
\hline \multicolumn{5}{|c|}{ ParâmetrosToxicológicos } \\
\hline SFo & Fator de Carcinogênicidade Oral & & $(1 /(\mathrm{mg} / \mathrm{kg}-\mathrm{dia}))$ & IRIS (2004) \\
\hline SFd & Fator de Carcinogênicidade Dermal & & $(1 /(\mathrm{mg} / \mathrm{kg}-\mathrm{dia}))$ & IRIS (2004) \\
\hline SFi & Fator de Carcinogênicidade por Inalação & & $(1 /(\mathrm{mg} / \mathrm{kg}-\mathrm{dia}))$ & $\operatorname{IRIS}(2004)$ \\
\hline URFi & Unidade de Risco & & $(1 /(\mu \mathrm{g} / \mathrm{m} 3))$ & IRIS (2004) \\
\hline RfDo & Dose de Referência Oral & $2,00 \mathrm{E}-02$ & (mg/kg-dia) & IRIS (2004) \\
\hline RfDd & Dose de Referência Dermal & $1,60 \mathrm{E}-02$ & (mg/kg-dia) & IRIS (2004) \\
\hline RfDi & Concentração de Referência para Inalação & $8,57 \mathrm{E}-04$ & (mg/kg-dia) & IRIS (2004) \\
\hline RAFo & Fator de Absorção Oral Relativa & $1,00 \mathrm{E}+00$ & - & IRIS (2004) \\
\hline RAFd & Fator de Absorção Dermal Relativa & $5,00 \mathrm{E}-02$ & - & IRIS (2004) \\
\hline $\mathrm{PCd}$ & Coeficiente de Permeabilidade & $6,90 \mathrm{E}-02$ & - & IRIS (2004) \\
\hline LTd & & $5,30 \mathrm{E}-01$ & (cm/ano) & IRIS (2004) \\
\hline CETd & & $2,20 \mathrm{E}+00$ & (cm/ano) & IRIS (2004) \\
\hline $\mathrm{CPd}$ & & $2,00 \mathrm{E}-01$ & (cm/ano) & IRIS (2004) \\
\hline \multicolumn{5}{|c|}{ ParâmetrosDependentes dos COC e do solo } \\
\hline UF & Fração não lonizável do Composto Químico em Agua & $1,00 \mathrm{E}+00$ & \multirow{2}{*}{\multicolumn{2}{|c|}{ (L-agua/L-ar) }} \\
\hline Heff & Coeficiente Efetivo da Lei de Henry & $2,01 \mathrm{E}-02$ & & \\
\hline Csat,vap & Concentração de Saturação de Vapor & $1,28 \mathrm{E}+03$ & \multicolumn{2}{|c|}{ (mg/m3-ar) } \\
\hline Ksw & Coeficiente de Partição Fase Retida - Agua Intersticial & 4,97E-02 & \multicolumn{2}{|c|}{ (L-agua/kg-solo) } \\
\hline Csat,sol & Concentração de Saturação do Solo & $1,54 \mathrm{E}+00$ & \multicolumn{2}{|c|}{ (mg/kg-solo) } \\
\hline Deff,sol & Coeficiente de Difusão no Solo & 5,05E-03 & \multicolumn{2}{|c|}{$(\mathrm{cm} 2 / \mathrm{seg})$} \\
\hline Deff,cap & Coeficiente de Difusão na Franja Capilar & $1,28 \mathrm{E}-04$ & \multicolumn{2}{|c|}{$(\mathrm{cm} 2 / \mathrm{seg})$} \\
\hline Deff,ws & Coeficiente de Difusão no Solo acima do Nível D'água & 3,39E-03 & \multicolumn{2}{|c|}{$(\mathrm{cm} 2 / \mathrm{seg})$} \\
\hline Deff,crk & Coeficiente de Difusão nas Fundações dos Prédios & $1,28 \mathrm{E}-02$ & \multicolumn{2}{|c|}{$(\mathrm{cm} 2 / \mathrm{seg})$} \\
\hline $\mathrm{Rc}$ & Fator de Retardação da Fase Dissolvida & $4,50 \mathrm{E}+01$ & \multirow{2}{*}{\multicolumn{2}{|c|}{$\frac{(\mathrm{cm} / \mathrm{s}) /(\mathrm{cm} / \mathrm{s})}{(\mathrm{cm} / \mathrm{s}) /(\mathrm{cm} / \mathrm{s})}$}} \\
\hline$\overline{\mathrm{Ri}}$ & Fator de Retardação da Fase Vapor & $2,81 \mathrm{E}-01$ & & \\
\hline \multicolumn{5}{|c|}{ Fatores de Volatilização entre Meios } \\
\hline & & RESIDENCIAL & COMERCIAL & \\
\hline VFs,esp & Fator de Volatilização do Solo Subsuperficial para Ambientes Fechados & $2,43 \mathrm{E}-04$ & $9,85 \mathrm{E}-05$ & (kg-solo/m3-ar) \\
\hline VFw,esp & Fator de Volatilização de Água Subterrânea para Ambientes Fechados & $3,08 \mathrm{E}-03$ & $1,25 \mathrm{E}-03$ & (L-água/m3-ar) \\
\hline VFss,amb,1 & Fator de Volatilização do Solo Superficial para Ambientes Abertos & 7,33E-06 & 7,33E-06 & (kg-solo/m3-ar) \\
\hline VFss,amb,2 & Fator de Volatilização do Solo Superficial para Ambientes Abertos & $8,38 \mathrm{E}-06$ & $8,38 \mathrm{E}-06$ & (kg-solo/m3-ar) \\
\hline VFss,amb & Fator de Volatilização do Solo Superficial para Ambientes Abertos & 7,33E-06 & 7,33E-06 & (kg-solo/m3-ar) \\
\hline LFsw & Fator de Lixiviação do Solo Subsuperficial para Agua & $2,81 \mathrm{E}-02$ & $2,81 \mathrm{E}-02$ & (kg-solo/L-ar) \\
\hline VFs,amb & Fator de Volatilização do Solo Subsuperficial para Ambientes Abertos & $3,36 \mathrm{E}-06$ & $3,36 \mathrm{E}-06$ & (kg-solo/m3-ar) \\
\hline VFw,amb & Fator de Volatilização de Agua Subterrânea para Ambientes Abertos & $1,74 \mathrm{E}-05$ & $1,74 \mathrm{E}-05$ & (L-água/m3-ar) \\
\hline VFp & Fator de Emissão de Partículas & $6,90 \mathrm{E}-12$ & $6,90 \mathrm{E}-12$ & (kg-solo/m3-ar) \\
\hline
\end{tabular}




\begin{tabular}{|l|c|}
\hline NOME: & PIRENO \\
\hline CAS RN: & $129-00-0$ \\
\hline FÓRMULA: & C16H10 \\
\hline
\end{tabular}

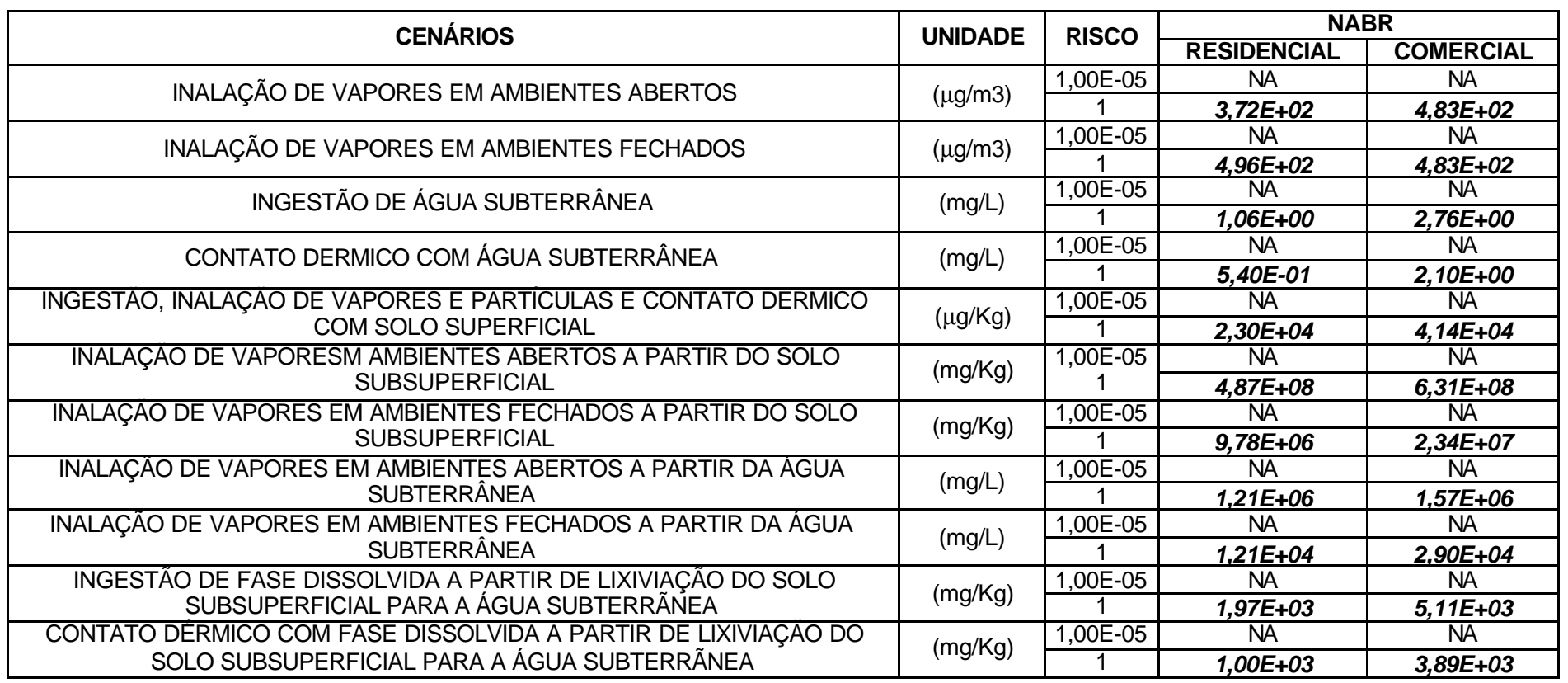

\begin{tabular}{|c|c|c|c|c|}
\hline \multicolumn{5}{|c|}{ Propriedades Físico-Químicas } \\
\hline PM & Peso Molecular & 202,3 & $(\mathrm{~g} / \mathrm{mol})$ & USEPA (1994) \\
\hline S & Solubilidade do Composto Puro em Agua & $1,35 \mathrm{E}-01$ & $(\mathrm{mg} / \mathrm{L})$ & Mackay(1992b) \\
\hline Pv & Pressão de Vapor & $5,11 \mathrm{E}-23$ & $(\mathrm{~mm} \mathrm{Hg})$ & USEPA (1994) \\
\hline $\mathrm{H}$ & Constante da Lei de Henry & 1,10E-05 & (atm-m3/mol) & USEPA (1996) \\
\hline Dar & Coeficiente de Difusão no $\mathrm{Ar}$ & $2,72 \mathrm{E}-02$ & $(\mathrm{~cm} 2 / \mathrm{seg})$ & USEPA (1996) \\
\hline Dag & Coeficiente de Difusão na Água & 7,24E-06 & $(\mathrm{cm} 2 / \mathrm{seg})$ & USEPA (1996) \\
\hline $\log (\mathrm{Koc})$ & Logarítimo do Coeficiente de Partição carbono Organico - Água & $5,02 \mathrm{E}+00$ & $\log (\mathrm{L}-\mathrm{agua} / \mathrm{kg}-\mathrm{oc})$ & WSPA(1993) \\
\hline Kd & Coeficiente de Partição Solo - Água & $1,05 \mathrm{E}+03$ & - & USEPA (1996) \\
\hline $\log ($ Kow $)$ & Coeficiente de partição Octanol - Água & $5,11 \mathrm{E}+00$ & $(\mathrm{mg} / \mathrm{L})$ & USEPA (1996) \\
\hline \multicolumn{5}{|c|}{ ParâmetrosToxicológicos } \\
\hline SFo & Fator de Carcinogênicidade Oral & & $(1 /(\mathrm{mg} / \mathrm{kg}-\mathrm{dia}))$ & IRIS (2004) \\
\hline SFd & Fator de Carcinogênicidade Dermal & & $(1 /(\mathrm{mg} / \mathrm{kg}-\mathrm{dia}))$ & IRIS (2004) \\
\hline SFi & Fator de Carcinogênicidade por Inalação & & $(1 /(\mathrm{mg} / \mathrm{kg}-\mathrm{dia}))$ & IRIS (2004) \\
\hline URFi & Unidade de Risco & & $(1 /(\mu \mathrm{g} / \mathrm{m} 3))$ & IRIS (2004) \\
\hline RfDo & Dose de Referência Oral & $3,00 \mathrm{E}-02$ & (mg/kg-dia) & IRIS (2004) \\
\hline RfDd & Dose de Referência Dermal & $9,30 \mathrm{E}-03$ & (mg/kg-dia) & IRIS (2004) \\
\hline RfDi & Concentração de Referência para Inalação & $1,05 \mathrm{E}-01$ & (mg/kg-dia) & IRIS (2004) \\
\hline RAFo & Fator de Absorção Oral Relativa & $1,00 \mathrm{E}+00$ & $x$ & IRIS (2004) \\
\hline RAFd & Fator de Absorção Dermal Relativa & $5,00 \mathrm{E}-02$ & - & IRIS (2004) \\
\hline $\mathrm{PCd}$ & Coeficiente de Permeabilidade & $3,20 \mathrm{E}-01$ & - & IRIS (2004) \\
\hline LTd & & & (cm/ano) & IRIS (2004) \\
\hline CETd & & & (cm/ano) & IRIS (2004) \\
\hline $\mathrm{CPd}$ & & & (cm/ano) & IRIS (2004) \\
\hline \multicolumn{5}{|c|}{ ParâmetrosDependentes dos COC e do solo } \\
\hline UF & Fração não lonizável do Composto Químico em Agua & $1,00 \mathrm{E}+00$ & & \\
\hline Heff & Coeficiente Efetivo da Lei de Henry & $4,58 \mathrm{E}-04$ & \multicolumn{2}{|c|}{ (L-agua/L-ar) } \\
\hline Csat,vap & Concentração de Saturação de Vapor & $5,66 \mathrm{E}-19$ & \multicolumn{2}{|c|}{ (mg/m3-ar) } \\
\hline Ksw & Coeficiente de Partição Fase Retida - Água Intersticial & 9,55E-04 & \multicolumn{2}{|c|}{ (L-agua/kg-solo) } \\
\hline Csat,sol & Concentração de Saturação do Solo & $1,29 \mathrm{E}-04$ & \multicolumn{2}{|c|}{$(\mathrm{mg} / \mathrm{kg}$-solo) } \\
\hline Deff,sol & Coeficiente de Difusão no Solo & $2,63 \mathrm{E}-03$ & \multicolumn{2}{|c|}{$(\mathrm{cm} 2 / \mathrm{seg})$} \\
\hline Deff,cap & Coeficiente de Difusão na Franja Capilar & 4,92E-03 & \multicolumn{2}{|c|}{$(\mathrm{cm} 2 / \mathrm{seg})$} \\
\hline Deff,ws & Coeficiente de Difusão no Solo acima do Nível D'água & $2,64 \mathrm{E}-03$ & \multirow{2}{*}{\multicolumn{2}{|c|}{$(\mathrm{cm} 2 / \mathrm{seg})$}} \\
\hline Deff,crk & Coeficiente de Difusão nas Fundações dos Prédios & 5,99E-03 & $(\mathrm{cm} 2 / \mathrm{seg})$ & \\
\hline $\mathrm{Rc}$ & Fator de Retardação da Fase Dissolvida & $2,31 \mathrm{E}+03$ & \multirow{2}{*}{\multicolumn{2}{|c|}{$\frac{(\mathrm{cm} / \mathrm{s}) /(\mathrm{cm} / \mathrm{s})}{(\mathrm{cm} / \mathrm{s}) /(\mathrm{cm} / \mathrm{s})}$}} \\
\hline $\mathrm{Ri}$ & Fator de Retardação da Fase Vapor & $5,41 \mathrm{E}-03$ & & \\
\hline \multicolumn{5}{|c|}{ Fatores de Volatilização entre Meios } \\
\hline & & RESIDENCIAL & COMERCIAL & \\
\hline VFs,esp & Fator de Volatilização do Solo Subsuperficial para Ambientes Fechados & $5,08 \mathrm{E}-08$ & $2,06 \mathrm{E}-08$ & (kg-solo/m3-ar) \\
\hline VFw,esp & Fator de Volatilização de Água Subterrânea para Ambientes Fechados & $4,10 \mathrm{E}-05$ & $1,66 \mathrm{E}-05$ & (L-água/m3-ar) \\
\hline VFss,amb,1 & Fator de Volatilização do Solo Superficial para Ambientes Abertos & $1,11 \mathrm{E}-07$ & $1,11 \mathrm{E}-07$ & (kg-solo/m3-ar) \\
\hline VFss,amb,2 & Fator de Volatilização do Solo Superficial para Ambientes Abertos & $8,38 \mathrm{E}-06$ & $8,38 \mathrm{E}-06$ & (kg-solo/m3-ar) \\
\hline VFss,amb & Fator de Volatilização do Solo Superficial para Ambientes Abertos & $1,11 \mathrm{E}-07$ & $1,11 \mathrm{E}-07$ & (kg-solo/m3-ar) \\
\hline LFsw & Fator de Lixiviação do Solo Subsuperficial para Agua & $5,40 \mathrm{E}-04$ & $5,40 \mathrm{E}-04$ & (kg-solo/L-ar) \\
\hline VFs,amb & Fator de Volatilização do Solo Subsuperficial para Ambientes Abertos & $7,65 \mathrm{E}-10$ & $7,65 \mathrm{E}-10$ & (kg-solo/m3-ar) \\
\hline VFw,amb & Fator de Volatilização de Agua Subterrânea para Ambientes Abertos & $3,08 \mathrm{E}-07$ & $3,08 \mathrm{E}-07$ & (L-água/m3-ar) \\
\hline VFp & Fator de Emissão de Partículas & $6,90 \mathrm{E}-12$ & $6,90 \mathrm{E}-12$ & (kg-solo/m3-ar) \\
\hline
\end{tabular}


FÓRMULA:

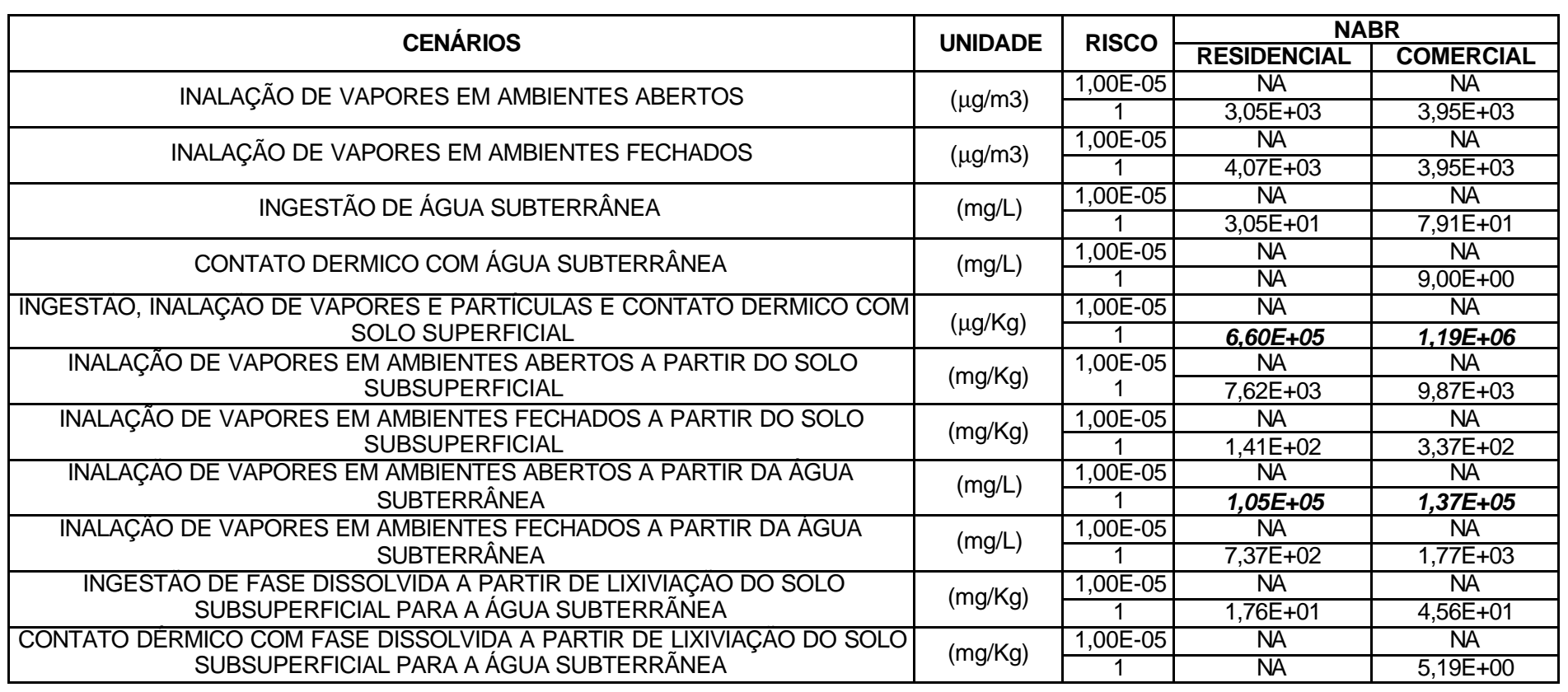

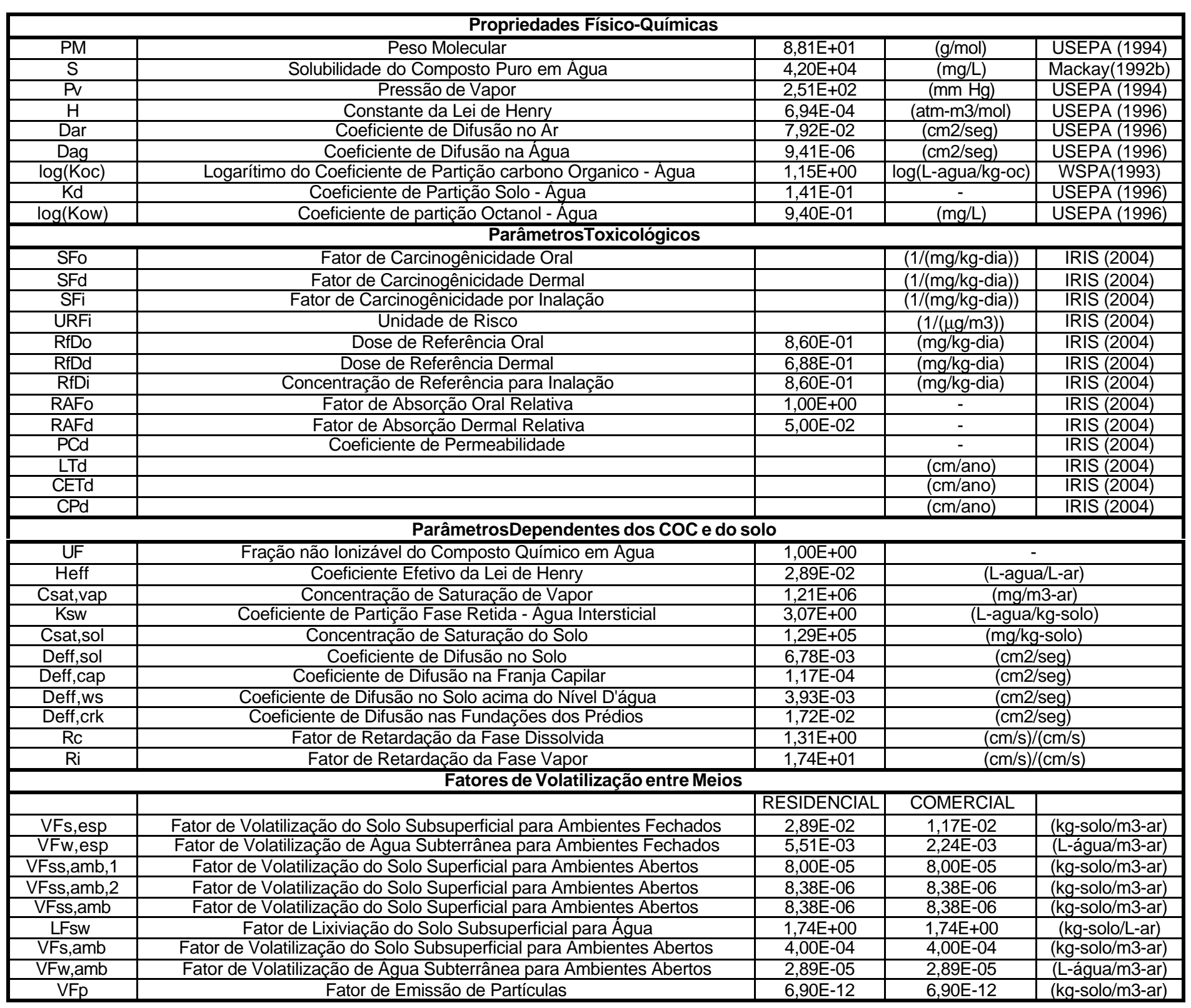




\begin{tabular}{|l|c|}
\hline NOME: & ETANOL \\
\hline CAS RN: & $64-17-5$ \\
\hline FORMULA: & C2H6O \\
\hline
\end{tabular}

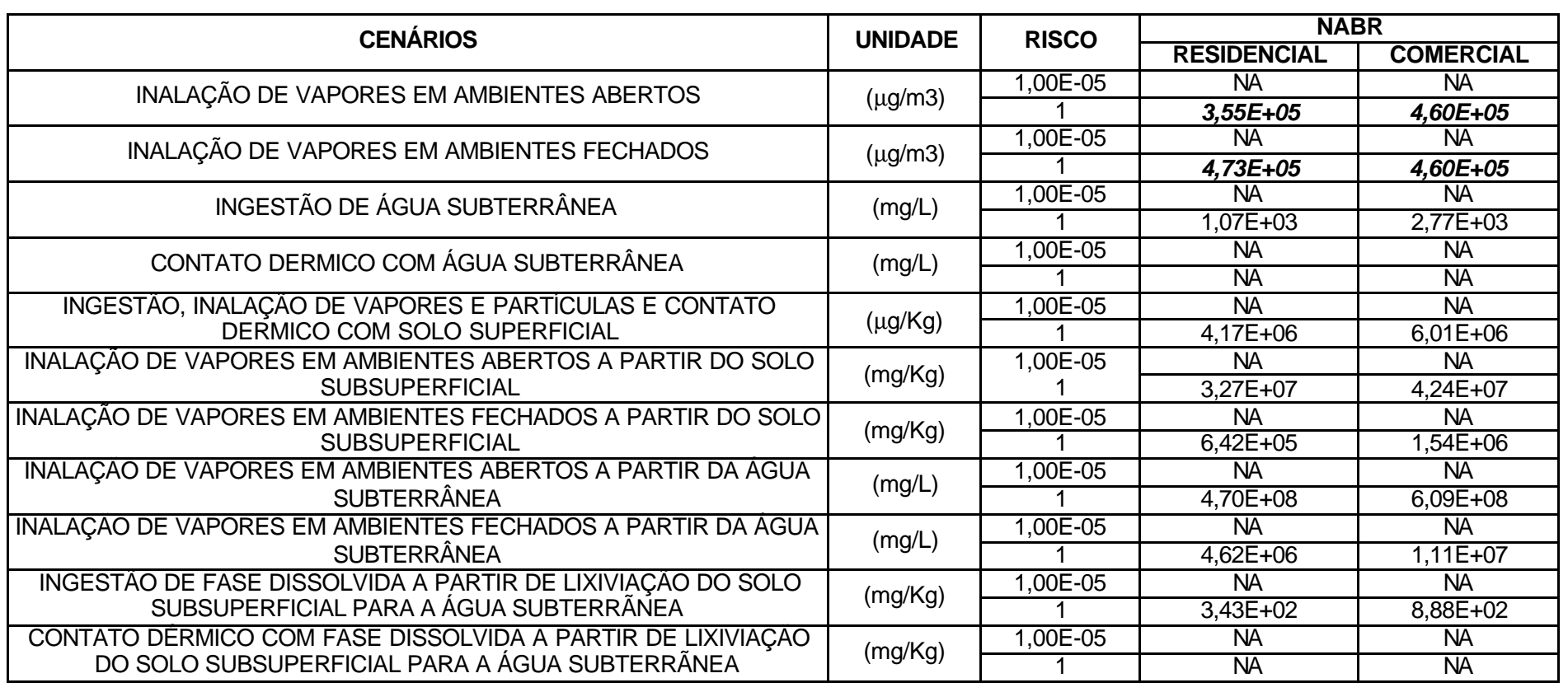

\begin{tabular}{|c|c|c|c|c|}
\hline \multicolumn{5}{|c|}{ Propriedades Físico-Químicas } \\
\hline$\overline{\mathrm{PM}}$ & Peso Molecular & $4,61 \mathrm{E}+01$ & $(\mathrm{~g} / \mathrm{mol})$ & USEPA (1994) \\
\hline $\mathrm{S}$ & Solubilidade do Composto Puro em Áqua & $1,00 \mathrm{E}+17$ & $(\mathrm{mg} / \mathrm{L})$ & Mackay (1992b) \\
\hline Pv & Pressão de Vapor & $4,39 \mathrm{E}+01$ & $(\mathrm{~mm} \mathrm{Hg})$ & USEPA (1994) \\
\hline $\mathrm{H}$ & Constante da Lei de Henry & $6,18 \mathrm{E}-06$ & (atm-m3/mol) & USEPA (1996) \\
\hline Dar & Coeficiente de Difusão no $\mathrm{Ar}$ & $1,23 \mathrm{E}-01$ & (cm2/seg) & USEPA (1996) \\
\hline Dag & Coeficiente de Difusão na Agua & $1,30 \mathrm{E}-05$ & (cm2/seg) & USEPA (1996) \\
\hline $\log (\mathrm{Koc})$ & Logarítimo do Coeficiente de Partição carbono Organico - Agua & $-3,06 \mathrm{E}-01$ & $\log (\mathrm{L}-\mathrm{mgua} / \mathrm{kg}-\mathrm{oc})$ & WSPA(1993) \\
\hline $\mathrm{Kd}$ & Coeficiente de Partição Solo - Aqua & $4,94 \mathrm{E}-03$ & - & USEPA (1996) \\
\hline $\log (\mathrm{Kow})$ & Coeficiente de partição Octanol - Água & $-3,20 \mathrm{E}-01$ & $(\mathrm{mg} / \mathrm{L})$ & USEPA (1996) \\
\hline \multicolumn{5}{|c|}{ ParâmetrosToxicológicos } \\
\hline SFo & Fator de Carcinogênicidade Oral & & $(1 /(\mathrm{mg} / \mathrm{kg}-\mathrm{dia}))$ & IRIS (2004) \\
\hline SFd & Fator de Carcinogênicidade Dermal & & $(1 /(\mathrm{mg} / \mathrm{kg}-\mathrm{dia}))$ & IRIS (2004) \\
\hline $\mathrm{SFi}$ & Fator de Carcinogênicidade por Inalação & & $(1 /(\mathrm{mg} / \mathrm{kg}-\mathrm{dia}))$ & IRIS (2004) \\
\hline URFi & Unidade de Risco & & $(1 /(\mu \mathrm{g} / \mathrm{m} 3))$ & IRIS (2004) \\
\hline RfDo & Dose de Referência Oral & $3,01 \mathrm{E}+01$ & (mg/kg-dia) & IRIS (2004) \\
\hline RfDd & Dose de Referência Dermal & $2,41 \mathrm{E}+01$ & (mg/kg-dia) & IRIS (2004) \\
\hline RfDi & Concentração de Referência para Inalação & $1,00 \mathrm{E}+02$ & (mg/kg-dia) & IRIS (2004) \\
\hline RAFo & Fator de Absorção Oral Relativa & $2,00 \mathrm{E}+00$ & - & IRIS (2004) \\
\hline RAFd & Fator de Absorcão Dermal Relativa & $5,00 \mathrm{E}-01$ & - & IRIS (2004) \\
\hline PCd & Coeficiente de Permeabilidade & & - & IRIS (2004) \\
\hline LTd & & & (cm/ano) & IRIS (2004) \\
\hline CETd & & & (cm/ano) & IRIS (2004) \\
\hline $\mathrm{CPd}$ & & & (cm/ano) & IRIS (2004) \\
\hline \multicolumn{5}{|c|}{ ParâmetrosDependentes dos COC e do solo } \\
\hline UF & Fração não lonizável do Composto Químico em Agua & $1,00 \mathrm{E}+00$ & & \\
\hline Heff & Coeficiente Efetivo da Lei de Henry & $2,57 \mathrm{E}-04$ & \multicolumn{2}{|c|}{ (L-agua/L-ar) } \\
\hline Csat,vap & Concentração de Saturação de Vapor & $1,11 \mathrm{E}+05$ & \multicolumn{2}{|c|}{$(\mathrm{mg} / \mathrm{m3}-\mathrm{ar})$} \\
\hline Ksw & Coeficiente de Partição Fase Retida - Água Intersticial & $5,51 \mathrm{E}+00$ & \multicolumn{2}{|c|}{ (L-agua/kg-solo) } \\
\hline Csat,sol & Concentracãa de Saturação do Solo & $5,51 \mathrm{E}+17$ & \multicolumn{2}{|c|}{ (mg/kg-solo) } \\
\hline Deff,sol & Coeficiente de Difusão no Solo & $1,15 \mathrm{E}-02$ & \multicolumn{2}{|c|}{$(\mathrm{cm} 2 / \mathrm{seg})$} \\
\hline Deff,cap & Coeficiente de Difusão na Franja Capilar & $1,57 \mathrm{E}-02$ & \multirow{2}{*}{\multicolumn{2}{|c|}{$\begin{array}{l}(\mathrm{cm} 2 / \mathrm{seg}) \\
(\mathrm{cm} / \mathrm{seg})\end{array}$}} \\
\hline Deff,ws & Coeficiente de Difusão no Solo acima do Nível D'água & $1,15 \mathrm{E}-02$ & & \\
\hline Deff,crk & Coeficiente de Difusão nas Fundações dos Prédios & $2,70 \mathrm{E}-02$ & \multicolumn{2}{|c|}{$(\mathrm{cm} 2 / \mathrm{seg})$} \\
\hline Rc & Fator de Retardação da Fase Dissolvida & $1,01 \mathrm{E}+00$ & \multicolumn{2}{|c|}{$(\mathrm{cm} / \mathrm{s}) /(\mathrm{cm} / \mathrm{s})$} \\
\hline $\mathrm{Ri}$ & Fator de Retardação da Fase Vapor & $3,12 \mathrm{E}+01$ & \multicolumn{2}{|c|}{$(\mathrm{cm} / \mathrm{s}) /(\mathrm{cm} / \mathrm{s})$} \\
\hline \multicolumn{5}{|c|}{ Fatores de Volatilização entre Meios } \\
\hline & & RESIDENCIAL & COMERCIAL & \\
\hline VFs,esp & Fator de Volatilização do Solo Subsuperficial para Ambientes Fechados & $7,36 \mathrm{E}-04$ & $2,99 \mathrm{E}-04$ & (kg-solo/m3-ar) \\
\hline VFw,esp & Fator de Volatilização de Agua Subterrânea para Ambientes Fechados & $1,02 \mathrm{E}-04$ & $4,15 \mathrm{E}-05$ & (L-água/m3-ar) \\
\hline VFss,amb, 1 & Fator de Volatilizacão do Solo Superficial para Ambientes Abertos & $1,32 \mathrm{E}-05$ & $1,32 \mathrm{E}-05$ & (kg-solo/m3-ar) \\
\hline VFss,amb,2 & Fator de Volatilização do Solo Superficial para Ambientes Abertos & $8,38 \mathrm{E}-06$ & $8,38 \mathrm{E}-06$ & (kg-solo/m3-ar) \\
\hline VFss,amb & Fator de Volatilização do Solo Superficial para Ambientes Abertos & $8,38 \mathrm{E}-06$ & $8,38 \mathrm{E}-06$ & (kg-solo/m3-ar) \\
\hline LFsw & Fator de Lixiviacão do Solo Subsuperficial para Áqua & $3,11 \mathrm{E}+00$ & $3,11 \mathrm{E}+00$ & (kg-solo/L-ar) \\
\hline VFs,amb & Fator de Volatilização do Solo Subsuperficial para Ambientes Abertos & $1,08 \mathrm{E}-05$ & $1,08 \mathrm{E}-05$ & (kg-solo/m3-ar) \\
\hline VFw,amb & Fator de Volatilização de Água Subterrânea para Ambientes Abertos & $7,54 \mathrm{E}-07$ & $7,54 \mathrm{E}-07$ & (L-água/m3-ar) \\
\hline VFp & Fator de Emissão de Partículas & $6,90 \mathrm{E}-12$ & $6,90 \mathrm{E}-12$ & (kg-solo/m3-ar) \\
\hline
\end{tabular}


ANEXO B

Lista Holandesa 


\section{Lista holandesa de valores de qualidade do solo e da água subterrânea - Valores STI}

A partir do conceito de multifuncionalidade do solo estabelecido em 1987, por meio da promulgação da Lei de Proteção do Solo (Soil Protection Act) pelo governo federal holandês, o Ministério de Planejamento Territorial e Meio Ambiente da Holanda (VROM), em atendimento a essa lei, publicou em 1994 a nova proposta de valores de qualidade do solo e da água subterrânea.

A característica principal dessa proposta é a criação de três valores distintos (STI) de qualidade para os compartimentos ambientais citados, ou seja:

Valor de referência (S): indica um nível de qualidade do solo e da água subterrânea que permite considerá-los "limpos", considerando-se a sua utilização para qualquer finalidade.

Valor de intervenção (I): indica um nível de qualidade do solo acima do qual existem riscos para a saúde humana e para o ambiente. A ultrapassagem desse valor (média) em um volume de solo de $25 \mathrm{~m}^{3}$ ou em $100 \mathrm{~m}^{3}$ de água subterrânea, indica a necessidade de implementação na área avaliada de ações voltadas para a sua remediação.

Valor de alerta $(\mathrm{T})$ : é um valor médio entre os dois primeiros $\mathrm{S}$ e I. Ele indica que já ocorreu uma certa alteração que diminuiu, ainda que pouco, as propriedades funcionais do solo, sendo necessária uma investigação detalhada na área para quantificação dessa alteração.

\section{Valor de referência (S)}

Para o valor de referência para as substâncias naturalmente presentes no solo, utilizou-se os valores de background (valores naturais ou devido à contaminação difusa pela atmosfera) como ponto de partida. Para esse propósito, os maiores valores naturais encontrados para os metais foram adotados. Para outras substâncias, o valor $S$ foi calculado tomando-se por base um risco desprezível para a saúde humana e para o ambiente. Segundo THEELEN \& NIJHOF (1996) citados em CETESB (1997), os valores de referência para substâncias antropogênicas adotados são os limites de detecção dos métodos analíticos adotados, considerando-se a melhor tecnologia disponível.

Para algumas substâncias o valor de referência depende do tipo de solo, tendo sido encontrada correlação significativa com o conteúdo de argila e de matéria orgânica. A partir dessa correlação foram estabelecidas fórmulas, por meio de equações de regressão para estabelecimento dos valores $S$, de acordo com os teores dos parâmetros acima citados. 
A possibilidade de fazer-se o uso de valores específicos para cada tipo de solo está baseada em:

- No fato de que o conteúdo natural de metais nos solos argilosos ser superior ao encontrado nos solos arenosos.

- A elevação do conteúdo de matéria orgânica no solo diminuir a sua densidade, elevando a concentração de metais por volume de solo.

- No fato de que a maior parte das substâncias contaminadoras do solo estar ligada à fração argila e orgânica do solo.

\section{Valor de intervenção (I)}

O valor de intervenção, conforme já comentado, indica o nível de qualidade do solo, acima do qual os riscos para o ser humano e meio ambiente são considerados inaceitáveis. Esses valores foram determinados pela quantificação dos riscos toxicológicos e ecotoxicológicos advindos da contaminação do solo.

Os riscos para a saúde humana foram quantificados pelo uso de um modelo denominado Csoil, considerando-se nesses cálculos as propriedades físicas e químicas dos solos, características dos contaminantes, dados de seu efeitos tóxicos ou carcinogênicos e estimativas de ingresso desses contaminantes pelas vias de exposição relevantes.

Os riscos para o ambiente foram calculados de maneira indireta, e indicam a concentração no solo de determinado contaminante, acima da qual $50 \%$ das espécies do ecossistema avaliado foram afetadas de alguma forma.

As tabelas a seguir apresentam, como exemplo, os valores de qualidade para um solo contendo de 0 a $10 \%$ de matéria orgânica e de 0 a $25 \%$ de argila. 
Tabela 6530-1: Valores referenciais para solo, considerando-se um teor de argila e de matéria orgânica de $0 \%$.

\begin{tabular}{|c|c|c|c|}
\hline \multirow[t]{2}{*}{ Parâmetro } & \multicolumn{3}{|c|}{ Concentração em peso seco $\left(\mathrm{mg} \cdot \mathrm{kg}^{-1}\right)$} \\
\hline & S & $T$ & I \\
\hline \multicolumn{4}{|l|}{ Inorgânicos } \\
\hline Arsênio & 15 & 21,7 & 28,4 \\
\hline Bário & 39 & 80 & 121 \\
\hline Cádmio & 0,4 & 3,3 & 6,1 \\
\hline Cromo & 50 & 120 & 190 \\
\hline Cobre & 15 & 47 & 79 \\
\hline Chumbo & 50 & 181 & 312 \\
\hline Mercúrio & 0,2 & 3,5 & 6,6 \\
\hline Cobalto & 4 & 29 & 53 \\
\hline Molibidênio & 10 & 105 & 200 \\
\hline Níquel & 10 & 35 & 60 \\
\hline Zinco & 50 & 154 & 257 \\
\hline \multicolumn{4}{|l|}{ Compostos inorgânicos } \\
\hline Cianetos (livre) & 1 & 11 & 20 \\
\hline Cianetos-complexados $(\mathrm{pH}<5)$ & 5 & 328 & 650 \\
\hline Cianetos-complexados $(\mathrm{pH}=$ ou $>5)$ & 5 & 28 & 50 \\
\hline Tiocianetos (soma) & - & 10 & 20 \\
\hline \multicolumn{4}{|l|}{ Compostos aromáticos } \\
\hline Benzeno & 0,01 & 0,11 & 0,20 \\
\hline Tolueno & 0,01 & 13,0 & 26,0 \\
\hline Etilbenzeno & 0,01 & 5,0 & 10,0 \\
\hline Xileno (soma) ${ }^{1}$ & 0,01 & 2,5 & 5,0 \\
\hline Fenol & 0,01 & 4,0 & 8,0 \\
\hline Creosol $^{2}$ & - & 0,5 & 1,0 \\
\hline Catenol & - & 2,0 & 4,0 \\
\hline Resorcinol & - & 1,0 & 2,0 \\
\hline Hidroquinona & - & 1,0 & 2,0 \\
\hline \multicolumn{4}{|c|}{ Hidrocarbonetos Aromáticos Policíclicos } \\
\hline Naftaleno & - & - & - \\
\hline Fenantreno & - & - & - \\
\hline Antraceno & - & - & - \\
\hline Fluoranteno & - & - & - \\
\hline Benzo(a)antraceno & - & - & - \\
\hline Criseno & - & - & - \\
\hline Benzo(k)fluoranteno & - & - & - \\
\hline Benzo(a)pireno & - & - & - \\
\hline Benzo(ghi)perilene & - & - & - \\
\hline Indenol(1,2,3cd)pireno & - & - & - \\
\hline $\mathrm{PAH}$ (soma 10) ${ }^{3}$ & 0,2 & 4,1 & 8,0 \\
\hline
\end{tabular}


Continuação da Tabela 6530-1

\begin{tabular}{|c|c|c|c|}
\hline \multirow[t]{2}{*}{ Parâmetro } & \multicolumn{3}{|c|}{ Concentração em peso seco $\left(\mathrm{mg} \cdot \mathrm{kg}^{-1}\right)$} \\
\hline & $\mathbf{S}$ & $\bar{T}$ & $\mathbf{I}$ \\
\hline \multicolumn{4}{|l|}{ Hidrocarbonetos Clorados } \\
\hline Diclorometano & $\mathrm{D}$ & 2,0 & 4,0 \\
\hline Triclorometano & 0,0002 & 1,0 & 2,0 \\
\hline Tetraclorometano & 0,0002 & 0,1 & 0,2 \\
\hline 1,1-dicloroetano ${ }^{4}$ & - & 25 & 50 \\
\hline 1,2-dicloroetano & - & 0,4 & 0,8 \\
\hline 1,1,1-tricloroetano ${ }^{4}$ & - & 25 & 50 \\
\hline $1,1,2$-tricloroetano ${ }^{4}$ & - & 25 & 50 \\
\hline Vinilclorado & - & 0,010 & 0,020 \\
\hline Cis 1,2 -dicloeteno ${ }^{4}$ & - & 25 & 50 \\
\hline Tricloroeteno & 0,0002 & 6,0 & 12,0 \\
\hline Tetracloroeteno & 0,002 & 0,4 & 0,8 \\
\hline $\begin{array}{l}\text { Hidrocarbonetos clorados } \\
\text { remanescentes }\end{array}$ & - & 2,5 & 50 \\
\hline Clorobenzeno (soma) ${ }^{5}$ & - & 3,0 & 6 \\
\hline Monoclorobenzeno & D & - & - \\
\hline Diclorobenzeno (soma) & 0,002 & - & - \\
\hline Triclorobenzeno (soma) & 0,002 & - & - \\
\hline Tetraclorobenzeno (soma) & 0,002 & - & - \\
\hline Pentaclorobenzeno & 0,0005 & - & - \\
\hline Hexaclorobenzeno & 0,0005 & - & - \\
\hline Clorofenol (soma) $^{6}$ & - & 1,0 & 2,0 \\
\hline Monoclorofenol (soma) & 0,0005 & - & - \\
\hline Diclorofenol (soma) & 0,0006 & - & - \\
\hline Triclorofenol (soma) & 0,0002 & - & - \\
\hline Tetraclorofenol & 0,0002 & - & - \\
\hline Pentaclorofenol & 0,0004 & 0,5 & 1,0 \\
\hline Cloronaftaleno & - & 1,0 & 2,0 \\
\hline PCB (soma) ${ }^{7}$ & 0,004 & 0,1 & 0,2 \\
\hline
\end{tabular}


Continuação da Tabela 6530-1

\begin{tabular}{|c|c|c|c|}
\hline \multirow[t]{2}{*}{ Parâmetro } & \multicolumn{3}{|c|}{ Concentração em peso seco $\left(\mathrm{mg} \cdot \mathrm{kg}^{-1}\right)$} \\
\hline & $\mathbf{S}$ & $\bar{T}$ & I \\
\hline \multicolumn{4}{|l|}{ Pesticidas } \\
\hline DDD, DDE, DDT (soma) ${ }^{8}$ & 0,0005 & 0,4 & 0,8 \\
\hline Drins (soma) ${ }^{9}$ & - & 0,4 & 0,8 \\
\hline Aldrin & 0,0005 & - & - \\
\hline Dieldrin & 0,0001 & - & - \\
\hline Endrin & 0,0002 & - & - \\
\hline $\mathrm{HCH}-$ compostos (soma) ${ }^{10}$ & - & 0,2 & 0,4 \\
\hline Alfa $-\mathrm{HCH}$ & 0,0005 & - & - \\
\hline Beta $-\mathrm{HCH}$ & 0,0002 & - & - \\
\hline Gama - HCH (lindano) & 0,00001 & - & - \\
\hline Clorados remanescentes & - & 2,5 & 5 \\
\hline Carbaril & - & 0,5 & 1,0 \\
\hline Carbofuran & - & 0,2 & 0,40 \\
\hline Maneb & & 3,5 & 7,0 \\
\hline Atrazina & & 3,5 & 7,0 \\
\hline Não-clorados remanescentes & & 5,0 & 10,0 \\
\hline \multicolumn{4}{|l|}{ Compostos remanescentes } \\
\hline Ciclohexano & 0,02 & 27,0 & 54,0 \\
\hline Ftalatos (soma) ${ }^{11}$ & 0,02 & 6,0 & 12,0 \\
\hline Hidrocarbonetos de petróleo totais (TPH) & 10 & 505 & 1000 \\
\hline Piridina & 0,02 & 0,11 & 0,2 \\
\hline Estireno & 0,02 & 10,0 & 20,0 \\
\hline Tetrahidrofuram & 0,02 & 0,05 & 0,08 \\
\hline Tetrahidrotiofeno & 0,02 & 9,0 & 18,0 \\
\hline EOX $^{12}$ & - & - & - \\
\hline Índice-Fenol ${ }^{13}$ & - & - & - \\
\hline
\end{tabular}


Tabela 6530-2: Valores referenciais para solo, considerando-se um teor de argila de $25,0 \%$ e de matéria orgânica de 10,0\%.

\begin{tabular}{|c|c|c|c|}
\hline \multirow[t]{2}{*}{ Parâmetro } & \multicolumn{3}{|c|}{ Concentração em peso seco $\left(\mathrm{mg} \cdot \mathrm{kg}^{-1}\right)$} \\
\hline & $\mathbf{S}$ & $\mathbf{T}$ & $\mathbf{I}$ \\
\hline \multicolumn{4}{|l|}{ Inorgânicos } \\
\hline Arsênio & 29,0 & 42,0 & 55,0 \\
\hline Bário & 200,0 & 413,0 & 625,0 \\
\hline Cádmio & 0,8 & 6,4 & 12,0 \\
\hline Cromo & 100 & 240 & 380 \\
\hline Cobalto & 20 & 130 & 240 \\
\hline Cobre & 36 & 113 & 190 \\
\hline Mercúrio & 0,3 & 5,2 & 10,0 \\
\hline Chumbo & 85 & 308 & 530 \\
\hline Molibidênio & 10 & 105 & 200 \\
\hline Níquel & 35 & 123 & 210 \\
\hline Zinco & 140 & 430 & 720 \\
\hline \multicolumn{4}{|l|}{ Compostos inorgânicos } \\
\hline Cianetos (livre) & 1 & 11 & 20 \\
\hline Cianetos-complexados $(\mathrm{pH}<5)$ & 5 & 328 & 650 \\
\hline Cianetos-complexados $(\mathrm{pH}=\mathrm{ou}>5)$ & 5 & 28 & 50 \\
\hline Tiocianetos (soma) & - & 10 & 20 \\
\hline \multicolumn{4}{|l|}{ Compostos aromáticos } \\
\hline Benzeno & 0,05 & 0,53 & 1,00 \\
\hline Tolueno & 0,05 & 65,0 & 130,0 \\
\hline Etilbenzeno & 0,05 & 25,0 & 50,0 \\
\hline Xileno (soma) ${ }^{1}$ & 0,05 & 12,5 & 25,0 \\
\hline Fenol & 0,05 & 20,0 & 40,0 \\
\hline Creosol $^{2}$ & - & 2,5 & 5,0 \\
\hline Catenol & - & 10,0 & 20,0 \\
\hline Resorcinol & - & 5,0 & 10,0 \\
\hline Hidroquinona & - & 5,0 & 10,0 \\
\hline \multicolumn{4}{|c|}{ Hidrocarbonetos Aromáticos Policíclicos } \\
\hline Naftaleno & - & - & - \\
\hline Fenantreno & - & - & - \\
\hline Antraceno & - & - & - \\
\hline Fluoranteno & - & - & - \\
\hline Benzo(a)antraceno & - & - & - \\
\hline Criseno & - & - & - \\
\hline Benzo(k)fluoranteno & - & - & - \\
\hline Benzo(a)pireno & - & - & - \\
\hline Benzo(ghi)perilene & - & - & - \\
\hline Indenol(1,2,3cd)pireno & - & - & - \\
\hline $\mathrm{PAH}$ (soma 10) ${ }^{3}$ & 1,0 & 20,5 & 40,0 \\
\hline
\end{tabular}


Continuação da Tabela 6530-2

\begin{tabular}{|c|c|c|c|}
\hline \multirow[t]{2}{*}{ Parâmetro } & \multicolumn{3}{|c|}{ Concentração em peso seco (mg.kg $\left.{ }^{-1}\right)$} \\
\hline & $\mathbf{S}$ & $\bar{T}$ & $\mathbf{I}$ \\
\hline \multicolumn{4}{|l|}{ Hidrocarbonetos Clorados } \\
\hline Diclorometano & D & 10,0 & 20,0 \\
\hline Triclorometano & 0,0010 & 5,0 & 10,0 \\
\hline Tetraclorometano & 0,0010 & 0,5 & 1,0 \\
\hline 1,1-dicloroetano ${ }^{4}$ & - & 25 & 50 \\
\hline 1,2-dicloroetano & - & 2,0 & 4,0 \\
\hline 1,1,1-tricloroetano ${ }^{4}$ & - & 25 & 50 \\
\hline 1,1,2-tricloroetano ${ }^{4}$ & - & 25 & 50 \\
\hline Vinilclorado & - & 0,050 & 0,10 \\
\hline Cis 1,2 -dicloeteno ${ }^{4}$ & - & 25 & 50 \\
\hline Tricloroeteno & 0,0010 & 30,0 & 60,0 \\
\hline Tetracloroeteno & 0,010 & 2,0 & 4,0 \\
\hline $\begin{array}{l}\text { Hidrocarbonetos clorados } \\
\text { remanescentes }\end{array}$ & - & 25 & 50 \\
\hline Clorobenzeno (soma) ${ }^{5}$ & - & 15,0 & 30 \\
\hline Monoclorobenzeno & D & - & - \\
\hline Diclorobenzeno (soma) & 0,010 & - & - \\
\hline Triclorobenzeno (soma) & 0,010 & - & - \\
\hline Tetraclorobenzeno (soma) & 0,0025 & - & - \\
\hline Pentaclorobenzeno & 0,0025 & - & - \\
\hline Hexaclorobenzeno & 0,0025 & - & - \\
\hline Clorofenol (soma) ${ }^{6}$ & - & 5,0 & 10 \\
\hline Monoclorofenol (soma) & 0,0025 & - & - \\
\hline Diclorofenol (soma) & 0,0030 & - & - \\
\hline Triclorofenol (soma) & 0,0010 & - & - \\
\hline Tetraclorofenol & 0,0010 & - & - \\
\hline Pentaclorofenol & 0,0020 & 2,5 & 5,0 \\
\hline Cloronaftaleno & - & 5,0 & 10,0 \\
\hline PCB (soma) ${ }^{7}$ & 0,020 & 0,5 & 1,0 \\
\hline
\end{tabular}


Continuação da Tabela 6530-2

\begin{tabular}{|c|c|c|c|}
\hline \multirow[t]{2}{*}{ Parâmetro } & \multicolumn{3}{|c|}{ Concentração em peso seco $\left(\mathrm{mg} \cdot \mathrm{kg}^{-1}\right)$} \\
\hline & $\mathbf{S}$ & $\bar{T}$ & $\mathbf{I}$ \\
\hline \multicolumn{4}{|l|}{ Pesticidas } \\
\hline DDD, DDE, DDT (soma) ${ }^{8}$ & 0,0025 & 2,0 & 4,0 \\
\hline Drins (soma) ${ }^{9}$ & - & 2,0 & 4,0 \\
\hline Aldrin & 0,0025 & - & - \\
\hline Dieldrin & 0,0005 & - & - \\
\hline Endrin & 0,0010 & - & - \\
\hline $\mathrm{HCH}-$ compostos (soma) ${ }^{10}$ & - & 1,0 & 2,0 \\
\hline Alfa $-\mathrm{HCH}$ & 0,0025 & - & - \\
\hline Beta $-\mathrm{HCH}$ & 0,0010 & - & - \\
\hline Gama - HCH (lindano) & 0,00005 & - & - \\
\hline Clorados remanescentes & - & 2,50 & 5,0 \\
\hline Carbaril & - & 2,50 & \\
\hline Carbofuran & - & 1,0 & 2,0 \\
\hline Maneb & - & 17,50 & 35,0 \\
\hline Atrazina & 0,00005 & 3,0 & 6,0 \\
\hline Não-clorados remanescentes & - & 5,0 & 10,0 \\
\hline \multicolumn{4}{|l|}{ Compostos remanescentes } \\
\hline Ciclohexano & 0,10 & 135,1 & 270,0 \\
\hline Ftalatos (soma) ${ }^{11}$ & 0,10 & 30,1 & 60,0 \\
\hline Hidrocarbonetos de petróleo totais (TPH) & 50,0 & 2525,0 & $5.000,0$ \\
\hline Piridina & 0,10 & 0,55 & 1,0 \\
\hline Estireno & 0,10 & 50,1 & 100,0 \\
\hline Tetrahidrofuram & 0,10 & 0,25 & 0,40 \\
\hline Tetrahidrotiofeno & 0,10 & 45,1 & 90,0 \\
\hline EOX $^{12}$ & - & - & - \\
\hline Índice-Fenol ${ }^{13}$ & - & - & - \\
\hline
\end{tabular}

- Os valores de referência (S) são dependentes das concentrações de background encontradas nos solos da Holanda. Dessa forma, a sua utilização em contextos geológicas diferentes não é recomendada.

- Os valores de alerta (T) e de Intervenção (I) constam da circular "Intervention values soil remediation". Netherlands Government Gazete 95, de 24 de maio de 1994.

- Com relação ao teor de argila, com exceção feita para os metais pesados, os limites mínimos de 5 e $2 \%$ respectivamente foram impostos. Os limites superiores foram de 50 e $30 \%$ respectivamente.

- Para os elementos que possuem apenas o valor de intervenção, o valor de alerta $(T)$ poderia ser calculado pela seguinte fórmula $T=0,50 \times \mathrm{I}$.

D - O valor de referência é menor do que o limite de detecção;

1 - Xileno (soma): somatório das formas meta-, ortho- e paraxileno;

2 - Creosol (soma): somatório das formas meta-, ortho- e paracreosol;

3 - PAH (soma): hidrocarbonetos poliaromáticos totais; 
4 - Os valores de intervenção foram calculados com base na circular "Intervention values soil remediation". Netherlands Government Gazete 95, de 24 de maio de 1994 e no RIVM report 725201007;

5 - Clorobenzeno (soma): soma do mono-, di-, tri-, tetra-, penta- e hexaclorobenzeno;

6 - Clorofenol (soma): soma de mono-, di-, tri-, tetra-, e pentaclorofenol;

7 - Bifenilas policloradas (totais): para o valor de intervenção, considerou-se as formas PCB 28, 52, 101, 118, 138, 153, e 180. Para os valores de referência a mesma soma foi utilizada excluindo-se o PCB 118;

8 - DDD, DDE, DDT (soma): soma de DDD, DDE e DDT;

9 - Drins (soma): soma de Aldrin, Dieldrin e Endrin;

$10-\mathrm{HCH}-c o m p o s t o s$ (soma): soma de alfa-, beta-, gama e delta- $\mathrm{HCH}$;

11 - Ftalatos (soma): soma de ftalatos;

12 - EOX: a sua determinação funcionou com gatilho para os compostos organohalogenados;

13 - Índice de fenol: sua análise funcionou como um gatilho para os Clorofenóis e Creosol. 
Tabela 6530-3: Valores referenciais para água subterrânea, considerando-se um solo com teor de argila e de matéria orgânica de $0 \%$.

\begin{tabular}{|c|c|c|c|}
\hline \multirow[t]{2}{*}{ Parâmetro } & \multicolumn{3}{|c|}{ Concentração em peso seco $\left(\mu \mathrm{g} \cdot \mathrm{L}^{-1}\right)$} \\
\hline & $\mathbf{S}$ & $T$ & $\mathbf{I}$ \\
\hline \multicolumn{4}{|l|}{ Inorgânicos } \\
\hline Arsênio & 10 & 35 & 60 \\
\hline Bário & 50 & 338 & 625 \\
\hline Cádmio & 0,4 & 3,2 & 6,0 \\
\hline Cromo & 1 & 16 & 30 \\
\hline Cobalto & 20 & 60 & 100 \\
\hline Cobre & 15 & 45 & 75 \\
\hline Mercúrio & 0,05 & 0,18 & 0,30 \\
\hline Chumbo & 15 & 45 & 75 \\
\hline Molibidênio & 5 & 153 & 300 \\
\hline Níquel & 15 & 45 & 75 \\
\hline Zinco & 65 & 433 & 800 \\
\hline \multicolumn{4}{|l|}{ Compostos inorgânicos } \\
\hline Cianetos (livre) & 5 & 753 & 1.500 \\
\hline Cianetos-complexados $(\mathrm{pH}<5)$ & 10 & 755 & 1.500 \\
\hline Cianetos-complexados $(\mathrm{pH}=\mathrm{ou}>5)$ & 10 & 755 & 1.500 \\
\hline Tiocianetos (soma) & - & 755 & 1.500 \\
\hline \multicolumn{4}{|l|}{ Compostos aromáticos } \\
\hline Benzeno & 0,2 & 15 & 30 \\
\hline Tolueno & 0,2 & 500 & 1.000 \\
\hline Etilbenzeno & 0,2 & 75 & 150 \\
\hline Xileno (soma) ${ }^{1}$ & 0,2 & 35 & 70 \\
\hline Fenol & 0,2 & 1.000 & 2.000 \\
\hline Creosol $^{2}$ & $\mathrm{D}$ & 100 & 200 \\
\hline Catenol & $\mathrm{D}$ & 625 & 1.250 \\
\hline Resorcinol & - & 300 & 600 \\
\hline Hidroquinona & - & 400 & 800 \\
\hline \multicolumn{4}{|c|}{ Hidrocarbonetos Aromáticos Policíclicos } \\
\hline Naftaleno & 0,1 & 35 & 70 \\
\hline Fenantreno & 0,02 & 2,5 & 5,0 \\
\hline Antraceno & 0,02 & 2,5 & 5,0 \\
\hline Fluoranteno & 0,005 & 0,5 & 1,0 \\
\hline Benzo(a)antraceno & 0,002 & 0,25 & 0,5 \\
\hline Criseno & 0,002 & 0,026 & 0,05 \\
\hline Benzo(k)fluoranteno & 0,001 & 0,026 & 0,05 \\
\hline Benzo(a)pireno & 0,001 & 0,026 & 0,05 \\
\hline Benzo(ghi)perilene & 0,0002 & 0,025 & 0,05 \\
\hline Indenol(1,2,3cd)pireno & 0,0004 & 0,025 & 0,05 \\
\hline $\mathrm{PAH}(\text { soma } 10)^{3}$ & - & - & - \\
\hline
\end{tabular}


Continuação da Tabela 6530-3

\begin{tabular}{|c|c|c|c|}
\hline \multirow[t]{2}{*}{ Parâmetro } & \multicolumn{3}{|c|}{ Concentração em peso seco $\left(\mu \mathrm{g} \cdot \mathrm{L}^{-1}\right)$} \\
\hline & $\mathbf{S}$ & $\bar{T}$ & I \\
\hline \multicolumn{4}{|l|}{ Hidrocarbonetos Clorados } \\
\hline Diclorometano & 0,01 & 500 & 1.000 \\
\hline Triclorometano & 0,01 & 200 & 400 \\
\hline Tetraclorometano & 0,01 & 5 & 10 \\
\hline 1,1-dicloroetano ${ }^{4}$ & - & 1.300 & 2.600 \\
\hline 1,2-dicloroetano & 0,01 & 200 & 400 \\
\hline 1,1,1-tricloroetano ${ }^{4}$ & - & 275 & 550 \\
\hline 1,1,2-tricloroetano ${ }^{4}$ & - & 750 & 1.500 \\
\hline Vinilclorado & - & 0,35 & 0,70 \\
\hline Cis 1,2 -dicloeteno ${ }^{4}$ & - & 650 & 1.300 \\
\hline Tricloroeteno & 0,01 & 250 & 500 \\
\hline Tetracloroeteno & 0,01 & 20 & 40 \\
\hline $\begin{array}{l}\text { Hidrocarbonetos clorados } \\
\text { remanescentes }\end{array}$ & - & - & - \\
\hline Clorobenzeno (soma) ${ }^{5}$ & - & - & - \\
\hline Monoclorobenzeno & 0,01 & 90 & 180 \\
\hline Diclorobenzeno (soma) & 0,01 & 25 & 50 \\
\hline Triclorobenzeno (soma) & 0,01 & 5 & 10 \\
\hline Tetraclorobenzeno (soma) & 0,01 & 1,26 & 2,5 \\
\hline Pentaclorobenzeno & 0,01 & 0,5 & 1 \\
\hline Hexaclorobenzeno & 0,01 & 0,26 & 0,5 \\
\hline Clorofenol (soma) ${ }^{6}$ & - & - & - \\
\hline Monoclorofenol (soma) & 0,25 & 50 & 100 \\
\hline Diclorofenol (soma) & 0,08 & 15 & 30 \\
\hline Triclorofenol (soma) & 0,025 & 5 & 10 \\
\hline Tetraclorofenol & 0,01 & 5 & 10 \\
\hline Pentaclorofenol & 0,02 & 1,5 & 3 \\
\hline Cloronaftaleno & - & 3 & 6 \\
\hline PCB (soma) ${ }^{7}$ & 0,01 & 0,01 & 0,01 \\
\hline
\end{tabular}


Continuação da Tabela 6530-3

\begin{tabular}{|c|c|c|c|}
\hline \multirow[t]{2}{*}{ Parâmetro } & \multicolumn{3}{|c|}{ Concentração em peso seco $\left(\mu \mathrm{g} \cdot \mathrm{L}^{-1}\right)$} \\
\hline & $\mathbf{S}$ & $\mathbf{T}$ & I \\
\hline \multicolumn{4}{|l|}{ Pesticidas } \\
\hline DDD, DDE, DDT (soma) ${ }^{8}$ & $\mathrm{D}$ & 0,005 & 0,01 \\
\hline Drins (soma) ${ }^{9}$ & - & 0,05 & 0,1 \\
\hline Aldrin & $\mathrm{D}$ & - & - \\
\hline Dieldrin & 0,00002 & - & - \\
\hline Endrin & $\mathrm{D}$ & - & - \\
\hline $\mathrm{HCH}-$ compostos (soma) ${ }^{10}$ & - & 0,5 & 1,0 \\
\hline Alfa $-\mathrm{HCH}$ & $\mathrm{D}$ & - & - \\
\hline Beta $-\mathrm{HCH}$ & D & - & - \\
\hline Gama - HCH (lindano) & 0,0002 & - & - \\
\hline Clorados remanescentes & - & - & - \\
\hline Carbaril & 0,01 & 0,06 & 0,1 \\
\hline Carbofuran & 0,01 & 0,06 & 0,1 \\
\hline Maneb & D & 0,05 & 0,1 \\
\hline Atrazina & $\mathrm{D}$ & 0,05 & 0,1 \\
\hline Não-clorados remanescentes & - & - & - \\
\hline \multicolumn{4}{|l|}{ Compostos remanescentes } \\
\hline Ciclohexano & 0,5 & 7.500 & 15.000 \\
\hline Ftalatos (soma) ${ }^{11}$ & 0,5 & 2,75 & 5 \\
\hline Hidrocarbonetos de petróleo totais (TPH) & 50 & 325 & 600 \\
\hline Piridina & 0,5 & 1,75 & 3 \\
\hline Estireno & 0,5 & 150 & 300 \\
\hline Tetrahidrofuram & 0,5 & 0,75 & 1 \\
\hline Tetrahidrotiofeno & 0,5 & 15 & 30 \\
\hline EOX $^{12}$ & - & - & - \\
\hline Índice-Fenol ${ }^{13}$ & - & - & - \\
\hline
\end{tabular}


Tabela 6530-4: Valores referenciais para água subterrânea, considerando-se um solo com teor de argila de $25,0 \%$ e de matéria orgânica de $10,0 \%$.

\begin{tabular}{|c|c|c|c|}
\hline \multirow[t]{2}{*}{ Parâmetro } & \multicolumn{3}{|c|}{ Concentração em peso seco $\left(\mu \mathrm{g} \cdot \mathrm{L}^{-1}\right)$} \\
\hline & $\mathbf{S}$ & $\mathbf{T}$ & $\mathbf{I}$ \\
\hline \multicolumn{4}{|l|}{ Inorgânicos } \\
\hline Arsênio & 10 & 35 & 60 \\
\hline Bário & 50 & 338 & 625 \\
\hline Cádmio & 0,4 & 3,2 & 6,0 \\
\hline Cromo & 1 & 16 & 30 \\
\hline Cobalto & 20 & 60 & 100 \\
\hline Cobre & 15 & 45 & 75 \\
\hline Mercúrio & 0,05 & 0,18 & 0,30 \\
\hline Chumbo & 15 & 45 & 75 \\
\hline Molibidênio & 5 & 153 & 300 \\
\hline Níquel & 15 & 45 & 75 \\
\hline Zinco & 65 & 433 & 800 \\
\hline \multicolumn{4}{|l|}{ Compostos inorgânicos } \\
\hline Cianetos (livre) & 5 & 753 & 1.500 \\
\hline Cianetos-complexados $(\mathrm{pH}<5)$ & 10 & 755 & 1.500 \\
\hline Cianetos-complexados $(\mathrm{pH}=\mathrm{ou}>5)$ & 10 & 755 & 1.500 \\
\hline Tiocianetos (soma) & - & 750 & 1.500 \\
\hline \multicolumn{4}{|l|}{ Compostos aromáticos } \\
\hline Benzeno & 0,2 & 15 & 30 \\
\hline Tolueno & 0,2 & 500 & 1.000 \\
\hline Etilbenzeno & 0,2 & 75 & 150 \\
\hline Xileno (soma) ${ }^{1}$ & 0,2 & 35 & 70 \\
\hline Fenol & 0,2 & 1.000 & 2.000 \\
\hline Creosol $^{2}$ & $\mathrm{D}$ & 100 & 200 \\
\hline Catenol & $\mathrm{D}$ & 625 & 1.250 \\
\hline Resorcinol & - & 300 & 600 \\
\hline Hidroquinona & - & 400 & 800 \\
\hline \multicolumn{4}{|c|}{ Hidrocarbonetos Aromáticos Policíclicos } \\
\hline Naftaleno & 0,1 & 35 & 70 \\
\hline Fenantreno & 0,02 & 2,5 & 5 \\
\hline Antraceno & 0,02 & 2,5 & 5 \\
\hline Fluoranteno & 0,005 & 0,5 & 1 \\
\hline Benzo(a)antraceno & 0,002 & 0,25 & 0,5 \\
\hline Criseno & 0,002 & 0,026 & 0,05 \\
\hline Benzo(k)fluoranteno & 0,001 & 0,026 & 0,05 \\
\hline Benzo(a)pireno & 0,001 & 0,026 & 0,05 \\
\hline Benzo(ghi)perilene & 0,0002 & 0,025 & 0,05 \\
\hline Indenol(1,2,3cd)pireno & 0,0004 & 0,025 & 0,05 \\
\hline $\mathrm{PAH}\left(\right.$ soma 10) ${ }^{3}$ & - & - & - \\
\hline
\end{tabular}


Continuação da Tabela 6530-4

\begin{tabular}{|c|c|c|c|}
\hline \multirow[t]{2}{*}{ Parâmetro } & \multicolumn{3}{|c|}{ Concentração em peso seco $\left(\mu \mathrm{g} \cdot \mathrm{L}^{-1}\right)$} \\
\hline & $\mathbf{S}$ & $\bar{T}$ & $\mathbf{I}$ \\
\hline \multicolumn{4}{|l|}{ Hidrocarbonetos Clorados } \\
\hline Diclorometano & 0,01 & 500 & 1.000 \\
\hline Triclorometano & 0,01 & 200 & 400 \\
\hline Tetraclorometano & 0,01 & 5 & 10 \\
\hline 1,1-dicloroetano ${ }^{4}$ & - & 1.300 & 2.600 \\
\hline 1,2-dicloroetano & 0,01 & 200 & 400 \\
\hline 1,1,1-tricloroetano ${ }^{4}$ & - & 275 & 550 \\
\hline 1,1,2-tricloroetano ${ }^{4}$ & - & 750 & 1.500 \\
\hline Vinilclorado & - & 0,35 & 0,7 \\
\hline Cis 1,2-dicloeteno ${ }^{4}$ & - & 650 & 1.300 \\
\hline Tricloroeteno & 0,01 & 250 & 500 \\
\hline Tetracloroeteno & 0,01 & 20 & 40 \\
\hline $\begin{array}{l}\text { Hidrocarbonetos clorados } \\
\text { remanescentes }\end{array}$ & - & - & - \\
\hline Clorobenzeno (soma) ${ }^{5}$ & - & - & - \\
\hline Monoclorobenzeno & 0,01 & 90 & 180 \\
\hline Diclorobenzeno (soma) & 0,01 & 25 & 50 \\
\hline Triclorobenzeno (soma) & 0,01 & 5 & 10 \\
\hline Tetraclorobenzeno (soma) & 0,01 & 1,26 & 2,5 \\
\hline Pentaclorobenzeno & 0,01 & 0,5 & 1 \\
\hline Hexaclorobenzeno & 0,01 & 0,26 & 0,5 \\
\hline Clorofenol (soma) ${ }^{6}$ & - & - & - \\
\hline Monoclorofenol (soma) & 0,25 & 50 & 100 \\
\hline Diclorofenol (soma) & 0,08 & 15 & 30 \\
\hline Triclorofenol (soma) & 0,025 & 5 & 10 \\
\hline Tetraclorofenol & 0,01 & 5 & 10 \\
\hline Pentaclorofenol & 0,02 & 1,5 & 3 \\
\hline Cloronaftaleno & - & 3 & 6 \\
\hline 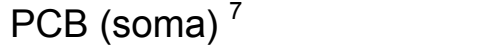 & 0,01 & 0,01 & 0,01 \\
\hline
\end{tabular}




\begin{tabular}{|c|c|c|c|}
\hline \multirow[t]{2}{*}{ Parâmetro } & \multicolumn{3}{|c|}{ Concentração em peso seco $\left(\mu \mathrm{g} \cdot \mathrm{L}^{-1}\right)$} \\
\hline & $\mathbf{S}$ & $T$ & $\mathbf{I}$ \\
\hline \multicolumn{4}{|l|}{ Pesticidas } \\
\hline DDD, DDE, DDT (soma) ${ }^{8}$ & $\mathrm{D}$ & 0,005 & 0,01 \\
\hline Drins (soma) ${ }^{9}$ & - & 0,05 & 0,1 \\
\hline Aldrin & D & - & - \\
\hline Dieldrin & 0,00002 & - & - \\
\hline Endrin & D & - & - \\
\hline $\mathrm{HCH}-$ compostos (soma) $^{10}$ & - & 0,5 & 1 \\
\hline Alfa $-\mathrm{HCH}$ & D & - & - \\
\hline Beta $-\mathrm{HCH}$ & $\mathrm{D}$ & - & - \\
\hline Gama - HCH (lindano) & 0,0002 & - & - \\
\hline Clorados remanescentes & - & - & - \\
\hline Carbaril & 0,01 & 0,06 & 0,1 \\
\hline Carbofuran & 0,01 & 0,06 & 0,1 \\
\hline Maneb & D & 0,05 & 0,1 \\
\hline Atrazina & 0,0075 & 75 & 150 \\
\hline Não-clorados remanescentes & - & - & - \\
\hline \multicolumn{4}{|l|}{ Compostos remanescentes } \\
\hline Ciclohexano & 0,5 & 7.500 & 15.000 \\
\hline Ftalatos (soma) ${ }^{11}$ & 0,5 & 2,75 & 5 \\
\hline Hidrocarbonetos de petróleo totais (TPH) & 50 & 325 & 600 \\
\hline Piridina & 0,5 & 1,75 & 3 \\
\hline Estireno & 0,5 & 150 & 300 \\
\hline Tetrahidrofuram & 0,5 & 0,75 & 1 \\
\hline Tetrahidrotiofeno & 0,5 & 15 & 30 \\
\hline $\mathrm{EOX}^{12}$ & - & - & - \\
\hline Índice-Fenol ${ }^{13}$ & - & - & - \\
\hline
\end{tabular}

- Os valores de referência (S) são dependentes das concentrações de background encontradas nos solos da Holanda. Dessa forma, a sua utilização em contextos geológicas diferentes não é recomendada.

- Os valores de alerta (T) e de Intervenção (I) constam da circular "Intervention values soil remediation". Netherlands Government Gazete 95, de 24 de maio de 1994.

- Com relação ao teor de argila, com exceção feita para os metais pesados, os limites mínimos de 5 e $2 \%$, respectivamente, foram impostos. Os limites superiores foram de 50 e $30 \%$, respectivamente.

- Para os elementos que possuem apenas o valor de intervenção, o valor de alerta $(\mathrm{T})$ poderia ser calculado pela seguinte fórmula $\mathrm{T}=0,50 \times \mathrm{I}$.

D - O valor de referência é menor do que o limite de detecção;

1 - Xileno (soma): somatório das formas meta-, ortho- e paraxileno;

2 - Creosol (soma): somatório das formas meta-, ortho- e paracreosol;

3 - PAH (soma): hidrocarbonetos poliaromáticos totais; 
4 - Os valores de intervenção foram calculados com base na circular "Intervention values soil remediation". Netherlands Government Gazete 95, de 24 de maio de 1994 e no RIVM report 725201007;

5 - Clorobenzeno (soma): soma do mono-, di-, tri-, tetra-, penta- e hexaclorobenzeno;

6 - Clorofenol (soma): soma de mono-, di-, tri-, tetra-, e pentaclorofenol;

7 - Bifenilas policloradas (totais): para o valor de intervenção, considerou-se as formas PCB 28, 52, 101, 118, 138, 153, e 180. Para os valores de referência, a mesma soma foi utilizada excluindo-se o PCB 118;

8 - DDD, DDE, DDT (soma): soma de DDD, DDE e DDT;

9 - Drins (soma): soma de Aldrin, Dieldrin e Endrin;

10 - $\mathrm{HCH}$-compostos (soma): soma de alfa-, beta-, gama e delta-HCH;

11 - Ftalatos (soma): soma de ftalatos;

12 - EOX: a sua determinação funcionou com gatilho para os compostos organohalogenados;

13 - Índice de fenol: sua análise funcionou como um gatilho para os Clorofenóis e Creosol.

\section{Referência bibliográfica}

MINISTRY OF HOUSING, PHYSICAL PLANNING AND ENVIRONMENT, The Netherlands, 1987, Soil Protection Act.

LOWER HOUSE OF THE STATES-GENERAL, The Netherlands, 1989-1990, Soil clean-up, Ten year Planning Scenario with Specific Reference to Industrial Sites.

VISSER, W., Contaminated land policies in some industrialized countries, Tecnical soil protection committee, 1993. 
ANEXO C

Valores orientadores para solos e águas subterrâneas no Estado de São

$$
\text { Paulo - } 2001
$$


Valores orientadores para solos e para águas subterrâneas no Estado de São Paulo, 2001.

\begin{tabular}{|c|c|c|c|c|c|c|}
\hline \multirow{4}{*}{ Substância } & \multicolumn{6}{|c|}{ VALORES ORIENTADORES } \\
\hline & \multicolumn{5}{|c|}{ Solos (mg.kg-1) } & $\begin{array}{l}\text { Águas } \\
\text { Subt. }\end{array}$ \\
\hline & \multirow[b]{2}{*}{ Referência } & \multirow[b]{2}{*}{ Alerta } & \multicolumn{4}{|c|}{ Intervenção } \\
\hline & & & $\begin{array}{l}\text { Agrícola } \\
\text { APMax }\end{array}$ & Residencial & Industrial & Intervenção \\
\hline Alumínio & - & - & - & - & - & $200^{(2)}$ \\
\hline Antimônio & $<0,5$ & 2,0 & 5,0 & 10,0 & 25 & $5^{(1)}$ \\
\hline Arsênio & 3,50 & 15 & 25 & 50 & 100 & $10^{(1)}$ \\
\hline Bário & 75 & 150 & 300 & 400 & 700 & $700^{(1)}$ \\
\hline Cádmio & $<0,5$ & 3 & 10 & 15 & 40 & $5^{(1)}$ \\
\hline Chumbo & 17 & 100 & 200 & 350 & 1200 & $10^{(1)}$ \\
\hline Cobalto & 13 & 25 & 40 & 80 & 100 & $30^{(5)}$ \\
\hline Cobre & 35 & 60 & 100 & 500 & 700 & $2000^{(1)}$ \\
\hline Cromo & 40 & 75 & 300 & 700 & 1000 & $50^{(1)}$ \\
\hline Ferro & - & - & - & - & - & $300^{(2)}$ \\
\hline Manganês & - & - & - & - & - & $100^{(2)}$ \\
\hline Mercúrio & 0,05 & 0,5 & 2,5 & 5 & 25 & $1^{(1)}$ \\
\hline Molibdênio & $<25$ & 30 & 50 & 100 & 120 & $250^{(5)}$ \\
\hline Níquel & 13 & 30 & 50 & 200 & 300 & $50^{(4)}$ \\
\hline Prata & 0,25 & 2 & 25 & 50 & 100 & $50^{(3)}$ \\
\hline Selênio & 0,25 & 5 & - & - & - & $10^{(1)}$ \\
\hline Vanádio & 275 & - & - & - & - & - \\
\hline Zinco & 60 & 300 & 500 & 1000 & 1500 & $5000^{(2)}$ \\
\hline Benzeno & 0,25 & - & 0,6 & 1,5 & 3,0 & $5^{(1)}$ \\
\hline Tolueno & 0,25 & - & 30 & 40 & 140 & $170^{(2)}$ \\
\hline Xilenos & 0,25 & - & 3,0 & 6,0 & 15 & $300^{(1)}$ \\
\hline Estireno & 0,05 & - & 15 & 35 & 80 & $20^{(1)}$ \\
\hline Naftaleno & 0,20 & - & 15 & 60 & 90 & $100^{(5)}$ \\
\hline Diclorobenzeno & 0,02 & - & 2,0 & 7,0 & 10,0 & $40^{(5)}$ \\
\hline Hexaclorobenzeno & 0,0005 & - & 0,1 & 1,0 & 1,5 & $1^{(1)}$ \\
\hline Tetracloroetileno & 0,10 & - & 1,0 & 1,0 & 10 & $40^{(1)}$ \\
\hline Tricloroetileno & 0,10 & - & 5,0 & 10 & 30 & $70^{(1)}$ \\
\hline 1,1,1 Tricloroetano & 0,001 & - & 8,0 & 20 & 50 & $600^{(5)}$ \\
\hline 1,2 Dicloroetano & 0,5 & - & 0,5 & 1,0 & 2,0 & $10^{(1)}$ \\
\hline Cloreto de Vinila & 0,5 & - & 0,1 & 0,2 & 0,7 & $5^{(1)}$ \\
\hline Pentaclorofenol & 0,001 & - & 2,0 & 5,0 & 15,0 & $9^{(1)}$ \\
\hline 2,4,6 Triclorofenol & 0,2 & - & 1,0 & 5,0 & 6,0 & $200^{(1)}$ \\
\hline Fenol & 0,3 & - & 5,0 & 10,0 & 15,0 & $0,1^{(3)}$ \\
\hline Aldrin e Dieldrin & 0,00125 & - & 0,5 & 1,0 & 5,0 & $0,003^{(1)}$ \\
\hline DDT & 0,0025 & - & 0,5 & 1,0 & 5,0 & $2^{(1)}$ \\
\hline Endrin & 0,00375 & - & 0,5 & 1,0 & 5,0 & $0,6^{(1)}$ \\
\hline Lindano (d-BHC) & 0,00125 & - & 0,5 & 1,0 & 5,0 & $2^{(1)}$ \\
\hline
\end{tabular}

1 - Padrão de Potabilidade da Portaria 1.469 do Ministério da Saúde para Substâncias que apresentam risco à saúde 
2 - Padrão de Potabilidade da Portaria 1.469 do Ministério da Saúde para aceitação de consumo (critério organoléptico).

3 - Padrão de Potabilidade da Portaria 36 do Ministério da Saúde;

4 - Comunidade Econômica Européia

5 - Com base no valor de intervenção para solos no Cenário Agrícola/Área de Proteção Máxima (APMax)

— não estabelecido 


\section{ANEXO D}

Valores orientadores para solos e águas subterrâneas no Estado de São

Paulo - 2005 


\section{CETESB - COMPANHIA DE TECNOLOGIA DE SANEAMENTO AMBIENTAL}

\section{DECISÃO DE DIRETORIA № 195-2005- E, de 23 de novembro de 2005}

Dispõe sobre a aprovação dos Valores Orientadores para Solos e Águas Subterrâneas no Estado de São Paulo - 2005, em substituição aos Valores Orientadores de 2001, e dá outras providências.

A Diretoria Plena da CETESB - Companhia de Tecnologia de Saneamento Ambiental, à vista do que consta do Processo no E-532-2005, considerando a manifestação do Departamento Jurídico, contida na Folha de Despacho PJ no 1799-2005, juntada às fls. 026, bem como o Relatório à Diretoria no 060-2005$\mathrm{E}$, que acolhe, DECIDE:

Artigo $1^{0}$ - Aprovar os Valores Orientadores para Solos e Águas Subterrâneas no Estado de São Paulo - 2005, constantes do Anexo Único que integra esta Decisão de Diretoria, em substituição à Tabela de Valores Orientadores aprovada pela Decisão de Diretoria no 014-01-E, de 26 de julho de 2001, e publicada no Diário Oficial do Estado, Empresarial, de 26 de outubro de 2001, continuando em vigor o Relatório "Estabelecimento de Valores Orientadores para Solos e Águas Subterrâneas no Estado de São Paulo", também aprovado pela Decisão de Diretoria no 014-01-E.

Parágrafo Único - Os Valores Orientadores aprovados por este artigo deverão ser revisados em até 4 (quatro) anos, ou a qualquer tempo, e submetidos à deliberação da Diretoria Plena da CETESB.

Artigo $2^{0}$ - No prazo de 6 (seis) meses, contado da publicação desta Decisão de Diretoria, as áreas técnicas competentes deverão submeter à Deliberação da Diretoria proposta de Norma Técnica CETESB, dispondo sobre a atualização do Relatório "Estabelecimento de Valores Orientadores para Solos e Águas Subterrâneas no Estado de São Paulo”, de que trata a Decisão de Diretoria no 014-01-E.

Artigo $3^{0}$ - Os Valores Orientadores para Solos e Águas Subterrâneas - 2005 deverão ser adotados, no que couber, em todas as regras pertinentes da CETESB e nas Normas Técnicas, já editadas ou a serem publicadas, especialmente as Normas Técnicas P 4.230 (agosto de 1999) e P 4.233 (setembro de 1999) com alterações posteriores, que dispõem, respectivamente, sobre a "Aplicação de Lodos de Sistemas de Tratamento Biológico em Áreas Agrícolas - Critérios para Projeto e Operação" e "Lodos de Curtumes - Critérios para o Uso em Áreas Agrícolas e Procedimentos para Apresentação de Projetos", que utilizem Valores Orientadores para a fixação de limite de concentração de substâncias no solo ou nas águas subterrâneas por elas estabelecido.

Artigo 4ำ - As áreas contaminadas somente serão reclassificadas nos casos em que todos os Valores de Intervenção $(\mathrm{VI})$ das substâncias responsáveis pela contaminação tenham sofrido alteração.

Artigo 5 - A Diretoria de Controle de Poluição Ambiental, no prazo de 160 (cento e sessenta) dias, contado da publicação desta Decisão de Diretoria, deverá fixar procedimento técnico-administrativo adequando as suas ações de controle aos novos Valores de Intervenção (VI).

Artigo 6ำ - Esta Decisão de Diretoria entra em vigor na data de sua publicação, surtindo seus efeitos na seguinte conformidade:

I - a partir de $1^{\circ}$ de junho de 2006 - aplicação dos Valores de Intervenção (VI) para as substâncias que, em relação aos publicados em 2001, tenham sofrido alteração para valores mais restritivos;

II - a partir da publicação desta Decisão - aplicação dos Valores de Intervenção (VI) para as substâncias que, em relação aos publicados em 2001, tenham mantidos os valores anteriores ou que tenham sofrido alteração para valores menos restritivos, bem como dos Valores de Intervenção para as novas substâncias relacionadas no Anexo Único que integra esta Decisão 


\section{ANEXO ÚNICO \\ a que se refere o artigo 1ำ da Decisão de Diretoria № 195-2005-E, de 23 de novembro de 2005}

\section{VALORES ORIENTADORES PARA SOLOS E ÁGUAS SUBTERRÂNEAS NO ESTADO DE SÃO PAULO}

Os Valores Orientadores são definidos e têm a sua utilização como segue:

Valor de Referência de Qualidade - VRQ é a concentração de determinada substância no solo ou na água subterrânea, que define um solo como limpo ou a qualidade natural da água subterrânea, e é determinado com base em interpretação estatística de análises físico-químicas de amostras de diversos tipos de solos e amostras de águas subterrâneas de diversos aqüíferos do Estado de São Paulo. Deve ser utilizado como referência nas ações de prevenção da poluição do solo e das águas subterrâneas e de controle de áreas contaminadas.

Valor de Prevenção - VP é a concentração de determinada substância, acima da qual podem ocorrer alterações prejudiciais à qualidade do solo e da água subterrânea. Este valor indica a qualidade de um solo capaz de sustentar as suas funções primárias, protegendo-se os receptores ecológicos e a qualidade das águas subterrâneas. Foi determinado para o solo com base em ensaios com receptores ecológicos. Deve ser utilizado para disciplinar a introdução de substâncias no solo e, quando ultrapassado, a continuidade da atividade será submetida a nova avaliação, devendo os responsáveis legais pela introdução das cargas poluentes proceder o monitoramento dos impactos decorrentes.

Valor de Intervenção - VI é a concentração de determinada substância no solo ou na água subterrânea acima da qual existem riscos potenciais, diretos ou indiretos, à saúde humana, considerado um cenário de exposição genérico. Para o solo, foi calculado utilizando-se procedimento de avaliação de risco à saúde humana para cenários de exposição Agrícola-Área de Proteção Máxima - APMax, Residencial e Industrial. Para a água subterrânea, considerou-se como valores de intervenção as concentrações que causam risco à saúde humana listadas na Portaria 518, de 26 de março de 2004, do Ministério da Saúde - MS, complementada com os padrões de potabilidade do Guia da Organização Mundial de Saúde - OMS de 2004, ou calculados segundo adaptação da metodologia da OMS utilizada na derivação destes padrões. Em caso de alteração dos padrões da Portaria 518 do MS, os valores de intervenção para águas subterrâneas serão conseqüentemente alterados. A área será classificada como Área Contaminada sob Investigação quando houver constatação da presença de contaminantes no solo ou na água subterrânea em concentrações acima dos Valores de Intervenção, indicando a necessidade de ações para resguardar os receptores de risco. 


\begin{tabular}{|c|c|c|c|c|c|c|c|}
\hline \multirow{3}{*}{ Substância } & \multirow{3}{*}{ CAS № } & \multicolumn{5}{|c|}{ Solo (mg.kg ${ }^{-1}$ de peso seco) ${ }^{(1)}$} & \multirow{3}{*}{$\begin{array}{c}\text { Água } \\
\text { Subterrânea } \\
\frac{\left(\mu \mathrm{g} \cdot \mathrm{L}^{-1}\right)}{\text { Intervenção }}\end{array}$} \\
\hline & & \multirow{2}{*}{$\begin{array}{c}\text { Referência } \\
\text { de } \\
\text { qualidade }\end{array}$} & \multirow[t]{2}{*}{ Prevenção } & \multicolumn{3}{|c|}{ Intervencão } & \\
\hline & & & & $\begin{array}{l}\text { Agrícola } \\
\text { APMax }\end{array}$ & Residencial & Industrial & \\
\hline \multicolumn{8}{|l|}{ Inorgânicos } \\
\hline Alumínio & $7429-90-5$ & & - & - & - & - & 200 \\
\hline Antimônio & $7440-36-0$ & $<0,5$ & 2 & 5 & 10 & 25 & 5 \\
\hline Arsênio & $7440-38-2$ & 3,5 & 15 & 35 & 55 & 150 & 10 \\
\hline Bário & $7440-39-3$ & 75 & 150 & 300 & 500 & 750 & 700 \\
\hline Boro & $7440-42-8$ & - & - & - & - & - & 500 \\
\hline Cádmio & $7440-48-4$ & $<0,5$ & 1,3 & 3 & 8 & 20 & 5 \\
\hline Chumbo & $7440-43-9$ & 17 & 72 & 180 & 300 & 900 & 10 \\
\hline Cobalto & $7439-92-1$ & 13 & 25 & 35 & 65 & 90 & 5 \\
\hline Cobre & $7440-50-8$ & 35 & 60 & 200 & 400 & 600 & 2.000 \\
\hline Cromo & $7440-47-3$ & 40 & 75 & 150 & 300 & 400 & 50 \\
\hline Ferro & $7439-89-6$ & & 8 & - & - & - & 300 \\
\hline Manganês & $7439-96-5$ & - & - & - & - & - & 400 \\
\hline Mercúrio & $7439-97-6$ & 0,05 & 0,5 & 12 & 36 & 70 & 1 \\
\hline Molibdênio & $7439-98-7$ & $<4$ & 30 & 50 & 100 & 120 & 70 \\
\hline Níquel & $7440-02-0$ & 13 & 30 & 70 & 100 & 130 & 20 \\
\hline Nitrato (como N) & $797-55-08$ & & - & - & - & - & 10.000 \\
\hline Prata & $7440-22-4$ & 0,25 & 2 & 25 & 50 & 100 & 50 \\
\hline Selênio & $7782-49-2$ & 0,25 & 5 & - & - & - & 10 \\
\hline Vanádio & $7440-62-2$ & 275 & - & - & - & - & - \\
\hline Zinco & $7440-66-6$ & 60 & 300 & 450 & 1000 & 2000 & 5.000 \\
\hline \multicolumn{8}{|c|}{ Hidrocarbonetos aromáticos voláteis } \\
\hline Benzeno & $71-43-2$ & na & 0,03 & 0,06 & 0,08 & 0,15 & 5 \\
\hline Estireno & $100-42-5$ & na & 0,2 & 15 & 35 & 80 & 20 \\
\hline Etilbenzeno & $100-41-4$ & na & 6,2 & 35 & 40 & 95 & 300 \\
\hline Tolueno & $108-88-3$ & na & 0,14 & 30 & 30 & 75 & 700 \\
\hline \multirow{2}{*}{\multicolumn{8}{|c|}{ Hidrocarbonetos policíclicos aromáticos ${ }^{(2)}$}} \\
\hline & & & & & & & \\
\hline Antraceno & $120-12-7$ & na & 0,039 & - & - & - & - \\
\hline Benzo(a)antraceno & $56-55-3$ & na & 0,025 & 9 & 20 & 65 & 1,75 \\
\hline Benzo(k)fluoranteno & 207-06-9 & na & 0,38 & - & - & - & - \\
\hline Benzo(g,h,i)perileno & $191-24-2$ & na & 0,57 & - & - & - & - \\
\hline Benzo(a)pireno & $50-32-8$ & na & 0,052 & 0,4 & 1,5 & 3,5 & 0,7 \\
\hline Criseno & $218-01-9$ & na & 8,1 & - & - & - & - \\
\hline Dibenzo(a,h)antraceno & $53-70-3$ & na & 0,08 & 0,15 & 0,6 & 1,3 & 0,18 \\
\hline Fenantreno & $85-01-8$ & na & 3,3 & 15 & 40 & 95 & 140 \\
\hline Indeno(1,2,3-c,d)pireno & $193-39-5$ & na & 0,031 & 2 & 25 & 130 & 0,17 \\
\hline Naftaleno & $91-20-3$ & na & 0,12 & 30 & 60 & 90 & 140 \\
\hline \multicolumn{8}{|l|}{ Benzenos clorados $^{(2)}$} \\
\hline Clorobenzeno (Mono) & $108-90-7$ & na & 0,41 & 40 & 45 & 120 & 700 \\
\hline 1,2-Diclorobenzeno & $95-50-1$ & na & 0,73 & 150 & 200 & 400 & 1.000 \\
\hline 1,3-Diclorobenzeno & $541-73-1$ & na & 0,39 & - & - & - & - \\
\hline 1,4-Diclorobenzeno & $106-46-7$ & na & 0,39 & 50 & 70 & 150 & 300 \\
\hline 1,2,3-Triclorobenzeno & $87-61-6$ & na & 0,01 & 5 & 15 & 35 & (a) \\
\hline 1,2,4-Triclorobenzeno & $120-82-1$ & na & 0,011 & 7 & 20 & 40 & (a) \\
\hline 1,3,5-Triclorobenzeno & $108-70-3$ & na & 0,5 & - & - & - & (a) \\
\hline 1,2,3,4-Tetraclorobenzeno & $634-66-2$ & na & 0,16 & - & - & - & - \\
\hline 1,2,3,5-Tetraclorobenzeno & $634-90-2$ & na & 0,0065 & - & - & - & - \\
\hline $1,2,4,5$-Tetraclorobenzeno & $95-94-3$ & na & 0,01 & - & - & - & - \\
\hline Hexaclorobenzeno & $118-74-1$ & na & $0,003^{(3)}$ & 0,005 & 0,1 & 1 & 1 \\
\hline \multicolumn{8}{|l|}{ Etanos clorados } \\
\hline 1,1-Dicloroetano & $75-34-2$ & na & - & 8,5 & 20 & 25 & 280 \\
\hline 1,2-Dicloroetano & $107-06-2$ & na & 0,075 & 0,15 & 0,25 & 0,50 & 10 \\
\hline 1,1,1-Tricloroetano & $71-55-6$ & na & - & 11 & 11 & 25 & 280 \\
\hline \multicolumn{8}{|l|}{ Etenos clorados } \\
\hline Cloreto de vinila & 75-01-4 & na & 0,003 & 0,005 & 0,003 & 0,008 & 5 \\
\hline
\end{tabular}




\begin{tabular}{|c|c|c|c|c|c|c|c|}
\hline $\begin{array}{l}\text { 1,1-Dicloroeteno } \\
\text { 1,2-Dicloroeteno - cis } \\
\text { 1,2-Dicloroeteno - trans } \\
\text { Tricloroeteno - TCE } \\
\text { Tetracloroeteno - PCE }\end{array}$ & $\begin{array}{l}75-35-4 \\
156-59-2 \\
156-60-5 \\
79-01-6 \\
127-18-4 \\
\end{array}$ & $\begin{array}{l}\text { na } \\
\text { na } \\
\text { na } \\
\text { na } \\
\text { na }\end{array}$ & $\begin{array}{l}- \\
- \\
- \\
0,0078 \\
0,054 \\
\end{array}$ & $\begin{array}{l}5 \\
1,5 \\
4 \\
7 \\
4 \\
\end{array}$ & $\begin{array}{l}3 \\
2,5 \\
8 \\
7 \\
5 \\
\end{array}$ & $\begin{array}{l}8 \\
4 \\
11 \\
22 \\
13 \\
\end{array}$ & $\begin{array}{l}30 \\
\text { (b) } \\
\text { (b) } \\
70 \\
40\end{array}$ \\
\hline \multicolumn{8}{|l|}{ Metanos clorados } \\
\hline Cloreto de Metileno & $75-09-2$ & na & 0,018 & 4,5 & 9 & 15 & 20 \\
\hline Clorofórmio & $67-66-3$ & na & 1,75 & 3,5 & 5 & 8,5 & 200 \\
\hline Tetracloreto de carbono & $56-23-5$ & na & 0,17 & 0,5 & 0,7 & 1,3 & \\
\hline \multicolumn{8}{|l|}{ Fenóis clorados } \\
\hline 2-Clorofenol (o) & $95-57-8$ & na & 0,055 & 0,5 & 1,5 & 2 & 10,5 \\
\hline 2,4-Diclorofenol & $120-83-2$ & na & 0,031 & 1,5 & 4 & 6 & 10,5 \\
\hline 3,4-Diclorofenol & $95-77-2$ & na & 0,051 & 1 & 3 & 6 & 10,5 \\
\hline 2,4,5-Triclorofenol & $95-95-4$ & na & 0,11 & - & - & - & 10,5 \\
\hline 2,4,6-Triclorofenol & $88-06-2$ & na & 1,5 & 3 & 10 & 20 & 200 \\
\hline 2,3,4,5-Tetraclorofenol & $4901-51-3$ & na & 0,092 & 7 & 25 & 50 & 10,5 \\
\hline 2,3,4,6-Tetraclorofenol & $58-90-2$ & na & 0,011 & 1 & 3,5 & 7,5 & 10,5 \\
\hline Pentaclorofenol (PCP) & $87-86-5$ & na & 0,16 & 0,35 & 1,3 & 3 & 9 \\
\hline \multicolumn{8}{|l|}{ Fenóis não clorados } \\
\hline Cresóis & & na & 0,16 & 6 & 14 & 19 & 175 \\
\hline Fenol & $108-95-2$ & na & 0,20 & 5 & 10 & 15 & 140 \\
\hline \multicolumn{8}{|l|}{ Ésteres ftálicos } \\
\hline Dietilexil ftalato (DEHP) & $117-81-7$ & na & 0,6 & 1,2 & 4 & 10 & 8 \\
\hline Dimetil ftalato & $131-11-3$ & na & 0,25 & 0,5 & 1,6 & 3 & 14 \\
\hline Di-n-butil ftalato & $84-74-2$ & na & 0,7 & - & - & - & - \\
\hline \multicolumn{8}{|c|}{ Pesticidas organoclorados } \\
\hline Aldrin ${ }^{(2)}$ & $309-00-2$ & na & $0,0015^{(3)}$ & 0,003 & 0,01 & 0,03 & (d) \\
\hline Dieldrin ${ }^{(2)}$ & $60-57-1$ & na & $0,043^{(3)}$ & 0,2 & 0,6 & 1,3 & (d) \\
\hline Endrin & $72-20-8$ & na & $0,001^{(3)}$ & 0,4 & 1,5 & 2,5 & 0,6 \\
\hline $\mathrm{DDT}^{(2)}$ & $50-29-3$ & na & $0,010^{(3)}$ & 0,55 & 2 & 5 & (c) \\
\hline $\mathrm{DDD}^{(2)}$ & $72-54-8$ & na & 0,013 & 0,8 & 3 & 7 & (c) \\
\hline $\mathrm{DDE}^{(2)}$ & $72-55-9$ & na & 0,021 & 0,3 & 1 & 3 & (c) \\
\hline $\mathrm{HCH}$ beta & $319-85-7$ & na & 0,011 & 0,03 & 0,1 & 5 & 0,07 \\
\hline$\underline{\mathrm{HCH} \text { - gama (Lindano) }}$ & $58-89-9$ & na & 0,001 & 0,02 & 0,07 & 1,5 & 2 \\
\hline \multicolumn{8}{|l|}{$\overline{\text { PCBs }}$} \\
\hline total & & na & $0,0003^{(3)}$ & 0,01 & 0,03 & 0,12 & 3,5 \\
\hline \multicolumn{8}{|c|}{$\begin{array}{l}\text { (1) - Procedimentos analíticos devem seguir SW-846, com metodologias de extração de inorgânicos 3050b ou } \\
3051 \text { ou procedimento equivalente. }\end{array}$} \\
\hline \multicolumn{8}{|c|}{$\begin{array}{l}\text { (2) - Para avaliação de risco, deverá ser utilizada a abordagem de unidade toxicológica por grupo de } \\
\text { substâncias. }\end{array}$} \\
\hline \multicolumn{8}{|c|}{$\begin{array}{l}\text { (3) - Substância banida pela Convenção de Estocolmo, ratificada pelo Decreto Legislativo n } 204 \text {, de } 07-05- \\
2004 \text {, sem permissão de novos aportes no solo. }\end{array}$} \\
\hline \multicolumn{8}{|c|}{ na - não se aplica para substâncias orgânicas. } \\
\hline \multicolumn{8}{|c|}{ (a) somatória para triclorobenzenos $=20 \mu \mathrm{g} \cdot \mathrm{L}^{-1}$. } \\
\hline \multicolumn{8}{|c|}{ (b) somatória para 1,2 dicloroetenos; $=50 \mu \mathrm{g} \cdot \mathrm{L}^{-1}$. } \\
\hline \multicolumn{8}{|c|}{ (c) somatória para DDT-DDD-DDE $=2 \mu \mathrm{g} \cdot \mathrm{L}^{-1}$. } \\
\hline \multicolumn{8}{|c|}{ (d) somatória para Aldrin e Dieldrin $=0,03 \mu \mathrm{g} \cdot \mathrm{L}^{-1}$. } \\
\hline
\end{tabular}

oOo 